UNIVERSIDADE DE SÃO PAULO

FACULDADE DE EDUCAÇÃO

Isaac Pedro Vieira Paxe

\title{
POLÍTICAS EDUCACIONAIS EM ANGOLA \\ desafios do direito à educação
}

São Paulo

2014

(Versão Corrigida) 
ISAAC PEDRO VIEIRA PAXE

\section{POLÍTICAS EDUCACIONAIS EM ANGOLA \\ desafios do direito à educação}

Tese apresentada ao Programa de Pós-Graduação da Faculdade de Educação da Universidade de São Paulo para a obtenção do título de Doutor em Educação.

Área de concentração: Estado, Sociedade e Educação

Orientador: Prof. Dr. Romualdo Luiz Portela de Oliveira 
Autorizo a reprodução e a divulgação total ou parcial deste trabalho, por qualquer meio convencional ou eletrônico, para fins de estudo e pesquisa, desde que citada a fonte.

Catalogação na Publicação

P366 Paxe, Isaac Pedro Vieira

Políticas educacionais em Angola: desafios do direito à educação / Isaac Pedro Vieira Paxe; orientação Prof. Dr. Romualdo L. P. Oliveira. São Paulo: s.n., 2014.

$217 f$.

Inclui anexos.

Tese (Doutorado) -- Universidade de São Paulo, 2014.

1. Educação 2. Direito à educação 3. Política Educacional 4. Angola. I. Título. II. Oliveira, Romualdo L. P. III. Universidade de São Paulo, Faculdade de Educação.

CDD 370

Ficha catalográfica: Bibliotecária Carmem Lúcia Batista, CRB/8 - 6673 
PAXE, Isaac Pedro Vieira

Políticas educacionais em Angola: desafios do direito à educação

Tese apresentada ao Programa de PósGraduação da Faculdade de Educação da Universidade de São Paulo para a obtenção do título de Doutor em Educação

Aprovado em: $/ 2014$

\section{Banca Examinadora}

Prof. Dr.: Romualdo L. Portela de Oliveira Instituição: FE/USP

Julgamento: Assinatura:

Prof. Dr.: Filipe Zau Instituição: UNIA / Angola

Julgamento: Assinatura:

Prof. Dr.: Rubens Barbosa de Camargo Instituição: FE/ USP

Julgamento: Assinatura:

Prof. Dr.: Adriana Aparecida D. Silveira Instituição: UFPR Julgamento: Assinatura:

Prof. Dr.: Giselle Cristina Martins Real Instituição: UFGD

Julgamento: Assinatura: 
Ao "Mais Velho" Antonio Lucas, pelo amparo e momentos no "parlamento".

À Alzira, Eddy, Saky e Luwa pelo projeto comum. 


\section{AGRADECIMENTOS}

Ao Governo do Reitor Sebastião Teta na UAN pela política de formação e ao INABE pela Bolsa de Estudos.

Ao Prof. Daniel Mingas pelos incentivos e apoios concedidos ao longo desta formação.

Ao Professor Romualdo de Oliveira, não apenas pelas ricas experiências na orientação e no grupo de estudos, mas também pelo processo de aceitação na FEUSP.

À Carmem Lúcia, colega, amiga, parceira, revisora, conselheira. Não há palavras para expressar a gratidão que temos por ti, e agradecemos o bendito dia que nos cruzamos nas salas da FEUSP e da FFLCH.

Aos colegas do Grupo de Estudo "Direito à educação", em particular à Nathalia - Nana - a Caroline Falco - Cacau, e a Malena de Carvalho pelos comentários oportunos deste trabalho.

Aos Professores Rubens de C. Barbosa, Vitor Paro, Eduardo Marques, Belmira Bueno Wagner Mancuso pelas experiências proporcionadas.

Aos colegas do grupo de estudo GEPAE pela qualidade das partilhas.

Aos amigos José e Gizela Malanda pelo apoio e camaradagem. Ao Leu e a Marisa pela amizade. Ao Silva e a Sónia Lumbongo pela solidariedade. E a Claudia Camila P. Baptista pelas vivências.

Aos amigos Emanuel Meque e Mbuta Zavua pelas cumplicidades e pela irmandade.

Aos meus irmãos biológicos e aos que a vida me deu pelo apoio espiritual, moral, financeiro enquanto este processo durou. Agradeço aos meus pais, Vieira e Terezinha, por me terem dado os irmãos que tenho, e ao "Kota" Jojo por me ter dado os manos Fernando e Ana Macedo. Ainda ao mano Fernando Macedo pelas discussões uteis sobre as ideias e os ideais que sustentam este trabalho.

Ao tio Eduardo da Cruz por ter estado presente ao longo das nossas vidas e ter de facto assumido as suas responsabilidades na nossa existência.

Aos amigos Profa. Adélia Cohen e Gabriela Cohen, Sousa Jamba, Santos Mussamo, Kezita Michingi, Mbiavanga Fernando, Tony Augusto Filipe e Ana Sófia e Manuel Mwanza pelo material disponibilizado sempre que precisei.

Aos manos Miriam Silva, Paula Duarte e Patrícia Zacarias pela constante e infinita solidariedade.

Ao professor Zivendele Sebastião pela disponibilidade e pelo apoio com material útil e raro.

Aos meus confrades do programa da Radio Mais "Conversas Com Vagar". 
Ao Salas Neto e sua equipe no Semanário Angolense pelo espaço disponibilizado para partilharmos ideias sobre a educação em Angola.

Ao Hermenegildo Seca pelas leituras dos esboços que fomos produzindo em diferentes momentos deste processo.

Às meninas da secretaria da EDA, Eloisa Felix, Solange Francisco e Raquel Silva pelo apoio dado ao longo da minha estada na Feusp

Ao Marcelo Ribeiro e a sua equipa na Secretaria da Pós Graduação pelo apoio prestado.

Ao nosso "Mais Velho" António Lucas e a Ana Terezinha, a mãe que a vida me deu, pelo amparo e orientação nos momentos de crise.

À minha família, Alzira, Eddy, Saky e Luwa pela compreensão, solidariedade, e pelos sacrifícios consentidos nestes anos todos. 
People know what they do and they generally know why they do what they do what people generally don't know is what what they do does

As pessoas sabem o que fazem e por norma sabem porque o fazem o que as pessoas por norma não sabem são os efeitos dos seus actos

Foucault 


\section{RESUMO}

PAXE, I. P. V. Políticas educacionais em Angola: desafios do direito à educação. 2014. 200f. Tese (Doutorado em Educação) - Faculdade de Educação, Universidade de São Paulo, São Paulo, 2014.

Este estudo examina o modo como a política pública educacional vigente efetiva a educação como um direito fundamental previsto na Constituição da República de Angola e em tratados internacionais como a Declaração Universal dos Direitos Humanos. O fundamento deste exame se assenta no princípio de que no Estado Constitucional, a ação deste resume-se na proteção e na garantia dos direitos individuais e coletivos conducentes a conferir valor a dignidade humana. Por isso, à educação, como política pública social e tarefa do Estado, é-lhe conferida créditos, quando garante o acesso de todos à ela, e a garantia da qualidade da educação oferecida aos que acedem a escola. Contudo, o sistema de educação em Angola, em diferentes momentos históricos, não assentou a sua ação necessariamente no princípio do Estado Constitucional, apesar de, depois de 1975, a educação ter sido formalmente declarada um direito. Esse processo histórico construiu obstáculos à efetivação do direito. Com a LBSE (Lei 13/01) teve início a implementação da política educacional que visou ajustar a educação à opção de Estado Democrático de Direito no contexto da segunda República. Mas, essa lei não fundamenta a educação como um direito a efetivar. Todavia, a materialização da política no sistema de educação revela a presença de ações que respondem às premissas do direito à educação. Tendo esses elementos em consideração, definimos como objetivo do estudo a compreensão de como é articulada a política em educação, especificamente no seu conteúdo, na efetivação do acesso e do atendimento como garantia do direito à educação em Angola. $\mathrm{O}$ referido estudo sustentou-se na análise documental e em referentes bibliográficos. Na categoria de documentos, analisamos alguma legislação de cada período abordado no estudo, isso serviu para situar alguns ideais políticos formalmente vigentes nessas realidades. Acreditamos que a análise da educação e das políticas públicas que a sustentam precisam considerar o ambiente econômico, político e o quadro legislativo em que ela se insere. Pudemos compreender que os obstáculos à efetivação do direito à educação resultam de opções de políticas anteriores que o prejudicaram a favor do cumprimento de agendas de governo instituídos. A política de educação corrente acentua a sua ação em dar resposta às ideias que sustentam a mundialização da educação, estas baseiam-se essencialmente nos fundamentos gerais da agenda mundial da educação. Isso concorre para a homogeneização na concepção de políticas locais. Esta perspectiva reduz o foco da abordagem que se espera que lide com as questões concretas da realidade local visando a superação destes obstáculos históricos à efetivação do direito, por isso, demandando o alargamento da arena da definição da agenda educacional para a participação efetiva da sociedade civil e prescindindo do centralismo vigente dominado pela ação do governo e das agencias internacionais.

Palavras-Chave: Direito à educação; Política educacional; Angola; Democratização da educação 


\begin{abstract}
PAXE, I. P. V. Educational policies in Angola: challenges of the right to education. 2014. 200p. Doctor's thesis in Education - Faculty of Education, University of São Paulo, São Paulo, 2014.

This study examines the way the current education policy accomplishes education as a fundamental right provided by the Republic of Angola Constitution and in international treaties such as the Universal Declaration of Human Rights. The foundations of this exam lies on the principle that in a constitutional state, its action is summed up on the protection and guarantee of individual and collective rights leading to lend value to human dignity. Therefore, education as a social and public policy gains credits when it grants the access of all to education as a state task, as well as grants a quality education to the ones within the education system. However, the system of education in Angola in different historical periods did not essentially ground its action on the constitutional principles, although education has been declared formally declared as a right since 1975. This historical process built some obstacles to achieve education rights goals. By the coming into power of LBSE (Lei 13/01), it initiates the implementation of education policy that sought to make education comply with the demands of a democratic rule of law state within the second republic context. But this law did not ground education as a right to be attained. Nevertheless, the implementation of the policy in the system of education reveals the presence of some actions that respond to the premises of the education right. Taking this into account, we defined as the objective of this study the understanding of the way that the education policy is thought, particularly in its content, to grant the access to quality education as a guarantee of the right to education in Angola. This study relies on archival and bibliographic references. In the archival ones, we studied some legislation of each covered period to understand some political ideals present in those realities. The belief is that the analysis of education and its supporting public policies need to consider the economic, political environment and the legislative framework in which it is operated. We could understand that the obstacles to make effective education rights resulted from the former political options that harmed this right in favor of the accomplishment of government agendas. The current education policy stresses its action in responding to the ideas that support the globalization of education, which foundations are the ideas on global education agenda. This favors the homogenization of local policy concepts. This perspective reduces the focus of the approach that is expected to deal with the concrete issues of the local context and the overcoming of the obstacles to education right accomplishment historically built. Thus, it demands the widening of education agenda setting arena to allow true participation of the civil society, and overcome the current centralization approach ruled by the government and international agencies.
\end{abstract}

Keywords: Right to education; Angola; Education policies; Democratic education 


\section{LISTA DE SIGLAS}

AGEE - Agenda Estruturada para a Educação

ANC - African National Congress

BM - Banco Mundial

CEMC - Cultura Educacional Mundial Comum

CPLP - Comunidade dos Países de Língua Portuguesa

CRA - Constituição da República de Angola

EPT - Educação Para Todas

FNLA - Frente Nacional para a Libertação de Angola

FNUAP - Fundo das Nações Unidas para a População

GEPE - Gabinete de Estudo Planeamento e Estatística

GURN - Governo de Unidade e Reconciliação Nacional

IBEP - Inquérito Integrado sobre o Bem Estar da População

IDH - Índice do Desenvolvimento Humano

INE - Instituto Nacional de Estatística

INIDE - Instituto Nacional de Investigação e Desenvolvimento da Educação

LBSE - Lei de Base do Sistema de Educação

MEC - Ministério da Educação e Cultura

MED - Ministério da Educação

MPLA - Movimento Popular de Libertação de Angola

MINFIN - Ministério das Finanças

ND - Nova Democracia

OCDE - Organização para a Cooperação e Desenvolvimento Económico

OGE - Orçamento Geral do Estado

ONG - Organização Não Governamental

ONU - Organização das Nações Unidas

OUA - Organização de Unida Africana

PALOP - Países Africanos de Língua Oficial Portuguesa

PAN/PET - Plano de Ação Nacional para a Educação Para Todos

PNUD - Programa das Nações Unidas para o Desenvolvimento 
PRS - Partido de Renovação Social

RPA - República Popular de Angola

SINPROF - Sindicato Nacional dos Professores

SWAPO - South West Africa People Organization

UA - União Africana

$\mathbf{U N}$ - United Nations

UNESCO - United Nations Education, Science and Culture Organization

UNICEF - United Nations Children's Fund (Fundo das Nações Unidas para a Infância)

UNITA - União Nacional para a Independência Total de Angola

UPA - União dos Povos de Angola

URSS - União das Repúblicas Socialistas Soviéticas 



\section{LISTA DE QUADROS}

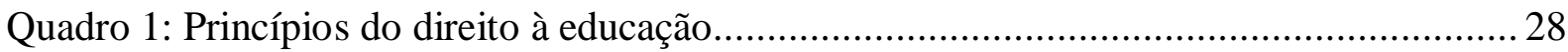

Quadro 2: Obrigações para cumprimento do direito à educação........................................ 32

Quadro 3: Conteúdos do ensino rudimentar Quadro 4: Conteúdos do ensino primário ..... 59

Quadro 5: Sistemas de educação na África pré-colonial .................................................. 88

Quadro 6: Instrumentos africanos sobre as línguas africanas ............................................ 93

Quadro 7: Escolarização de base por idades ..................................................................... 96

Quadro 8: Percentagem da População escolar de 5-18 anos sobre a situação escolar, idade e

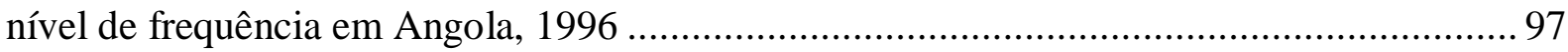

Quadro 9: Perfil dos professores (ensino de base) como definido pelo MED ..................... 107

Quadro 10: Comparação entre o novo sistema educativo e os Marcos de Dakar 2000......... 118

Quadro 11: Constatações e recomendações da consulta pública........................................ 123

Quadro 12: Objetivos da reforma e as atividades para os efetivar ................................... 133 


\section{LISTA DE TABELAS}

Tabela 1: População de Angola segundo os censos de 1940, 1950 e 1960 ........................... 53

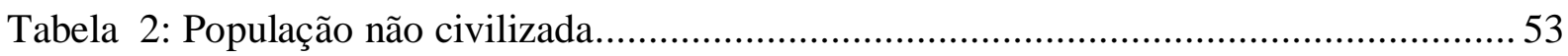

Tabela 3: População civilizada segundo a instrução em Angola.......................................... 54

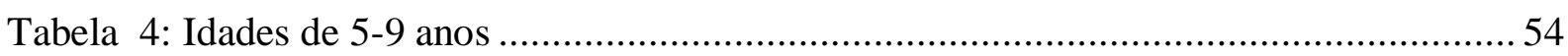

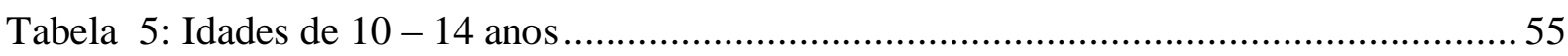

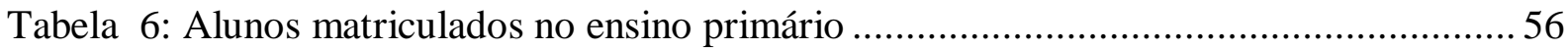

Tabela 7: Efetivos escolares no ensino primário (1977) ................................................. 94

Tabela 8: Alunos matriculados .................................................................................. 95

Tabela 9: Taxa de escolarização - Idades (6-14 anos) em 1990/91 ................................... 99

Tabela 10: Taxa de escolarização (5-18 anos) por regiões em 1996 .................................. 100

Tabela 11: Taxas nacionais agregadas de promoção, repetência e abandono (1989-90) ...... 101

Tabela 12: Evolução de alunos matriculados, 2001-2010 ................................................. 138

Tabela 13: População em Angola estimada por grupos etários, 2005-2008/ por milhões..... 139

Tabela 14: População 5-14 anos versus alunos matriculados no ensino público .................. 139

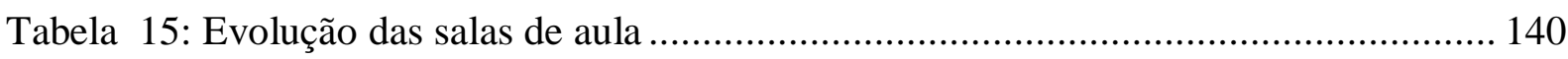

Tabela 16: Rácio de alunos / sala de aula, 2005-2008 .................................................... 140

Tabela 17: Rendimento interno (taxas de aprovação, reprovação e abandono) ................... 147

Tabela 18: Taxas de fluxo: experimentação (2004-2010)................................................. 148

Tabela 19: Orçamento da educação e dos respectivos programas em \% ............................. 168

Tabela 20: Orçamento da educação e dos respectivos níveis em \% .................................... 170 


\section{SUMÁRIO}

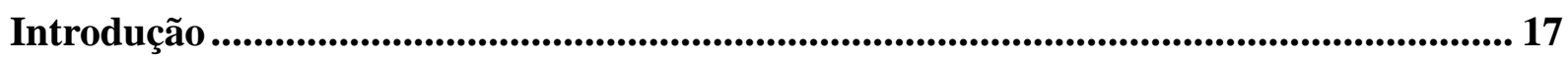

1 A educação como direito na política no período colonial (1960-1974) ........................ 37

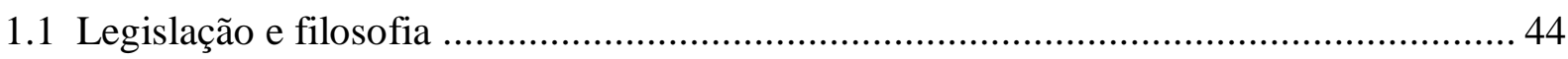

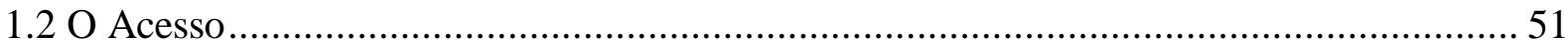

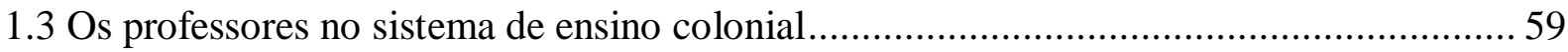

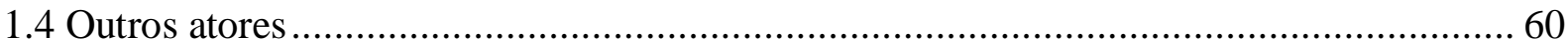

$2 \mathrm{O}$ direito à educação na política educacional na Primeira República (1975-1991)...... 64

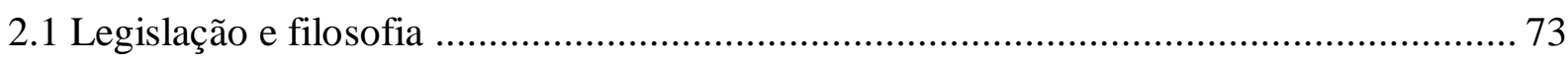

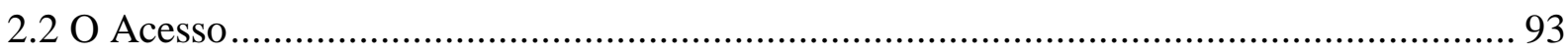

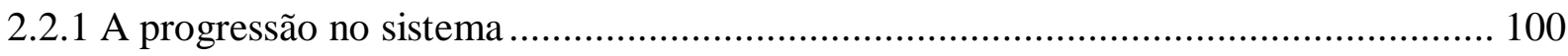

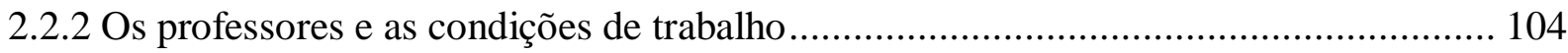

30 direito à educação na política educacional na Segunda República (1992-2012) ..... 108

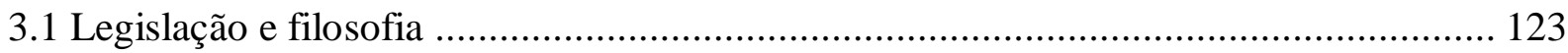

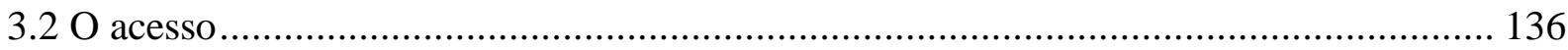

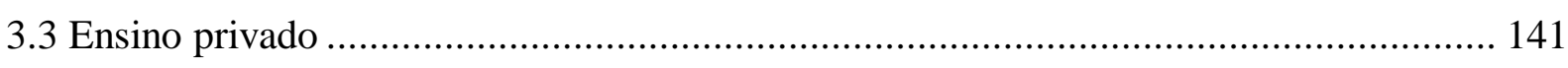

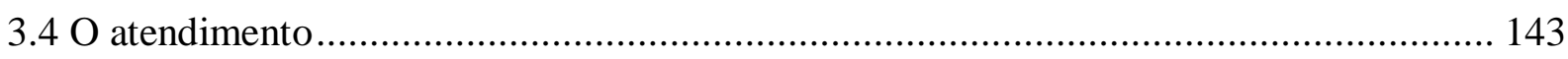

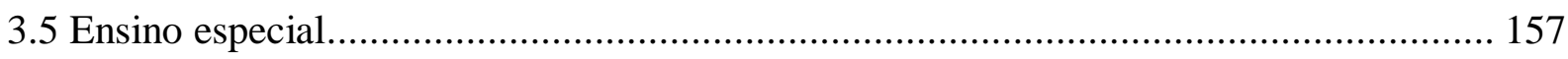

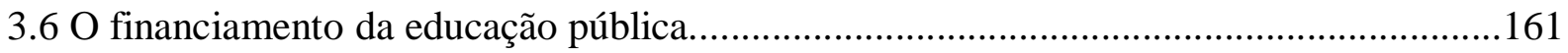

4 A política educacional face às suas orígens e seus fins............................................ 171

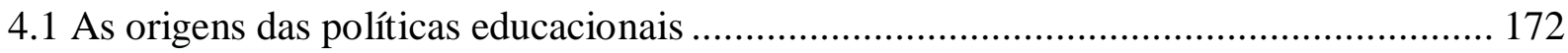

4.2. A adopção das políticas educacionais .................................................................. 180

4.3. A política educacional em Angola e sua origem ...................................................... 181

5 Considerações finais.................................................................................................................... 191

Referências ..................................................................................................................... 198

Anexo I - Sobre o Conselho da Revolução ........................................................................ 212

Anexo - Organograma do sistema de educação: idades mínimas de ingresso ...................... 213

Anexo III - Comparação entre o sistema de educação em vigor e o sistema de educação a

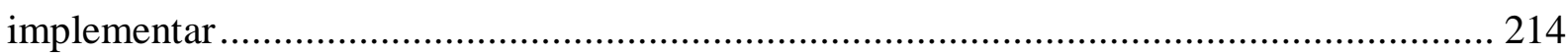

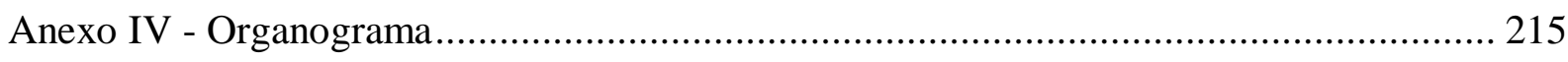

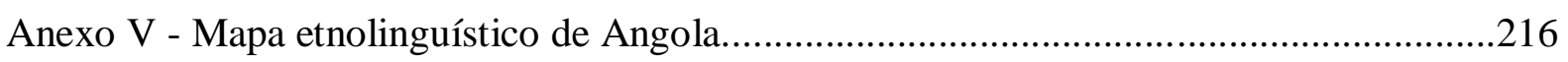

Anexo VI - Mapa de Angola e os países limítrofes.............................................................217 


\section{INTRODUÇÃO}

A educação escolar formal na República de Angola sempre constou nas agendas de projetos políticos, não somente nos programas de governo após a independência, como também nas agendas dos movimentos políticos para a independência do país. A educação surge como uma das reivindicações contra a política do governo colonial sob a égide de Portugal, que condicionava este direito à maior parte da população nativa ${ }^{1}$. Após a conquista da independência, em 1975, o governo instituído propôs-se a garantir a educação como instrumento para a consolidação do seu projeto político. Nesse contexto, é idealizado o princípio da democratização da educação escolar formal, que basicamente compreende a declaração do acesso, sem qualquer forma de descriminação, de todos os angolanos à educação. É atribuída à educação a tarefa de "construir o homem novo".

O triunfo da revolução para a autodeterminação dos povos de Angola tornou realidade o pensamento de que

[...] todo processo revolucionário identifica a educação, tarde ou cedo, como um instrumento chave para a transformação social. Os projetos políticos de distinta índole apostaram na mudança das estruturas pela via da formação do "homem novo". Em muitas sociedades a escola constitui-se no espaço privilegiado para os intentos de gerar as condições culturais para socializar as ideologias dos novos regimes. (ROCKWELL, 2007, p.11).

Contudo, Rockwell revela que apesar das declaradas pretensões desses governos na questão da educação, esta converteu-se no domínio ideal para demonstrar que os

\footnotetext{
${ }^{1}$ Adoptamos a designação nativos para os povos africanos cujos antecessores habitavam os territórios que configuram Angola ou territórios vizinhos. Angolanos, no período pré-independência, corresponde aos povos nascidos em Angola cujos, pelo menos, um dos antecessores tenha origem Europeia. Abordagens sobre essa questão assente em filosofias como a do nativismo e do nacionalismo podem ser encontradas em 1. Vozes de Angola clamando no deserto. Vários autores. Lisboa: Edições 70, 1984. 2. Pimenta, Fernando Tavares. Brancos de Angola: Autonomismo e nacionalismo (1900-1961). Coimbra: Minerva, 2005. 3. Laban, Michel. Angola: Encontro com escritores. Vol. I e II. Porto: Fundação Eng. António de Almeida, 1991. Na atualidade, a nacionalidade angolana é definida no artigo 9 da CRA, declarando que "a nacionalidade angolana pode ser originária ou adquirida[...] É cidadão angolano de origem, o filho de pai ou mãe de nacionalidade angolana, nascido em Angola ou no estrangeiro [...]. Presume-se cidadão angolano de origem o recém-nascido achado em território angolano". Para Araújo e Nunes (Constituição da República de Angola anotada. Tomo I. Luanda, 2014) ao fazerem as anotações à este artigo, dizem que "a nacionalidade angolana pode ser originária ou adquirida, sendo a primeira na condição quando o cidadão é filho de pai ou mãe angolano. Já a adquirida pode verificar-se por uma das seguintes vias: por filiação, por adopção, por casamento ou por naturalização.
} 
Estados pós-revolucionários quase nunca tinham conseguido o prometido. Afirmamos que assim também foi na Primeira República em Angola. Apesar de avanços no domínio do acesso à educação, o projeto inicial, segundo as próprias instituições encarregadas da educação, não se traduziu em eficientes e eficazes políticas públicas em educação.

Em decorrência da ordem mundial resultante do fim da União Soviética e dos países socialistas do leste europeu, em 1989, Angola enceta também mudanças políticas com vista à constituição de um Estado democrático de direito. É nesse contexto que a educação, conservando a sua condição de política social de domínio público, pode ser confrontada sobre a sua virtude em se efetivar como um direito de cidadania em razão do paulatino reconhecimento e da especificação dos valores inerentes aos direitos fundamentais dos cidadãos na sua condição humana, histórica e antropológica. É também no mesmo contexto que se encontram os fundamentos para se compreender as ideias que emergiram na abordagem da educação como política pública e que também emergiram atores na proposta da reforma da educação pública.

A compreensão da educação como uma política social de natureza pública a fim de aferir forças que concorrem para que os processos de reforma se iniciem, sejam implementados e apresentem resultados efetivos ou não, requer que a educação não seja analisada fora das relações do Estado com a sociedade civil e também com as organizações supranacionais. Ao fazer essa abordagem, Azevedo (2001) observa que:

[...] requer diluí-la na sua inserção mais ampla: o espaço teórico-analítico próprio das políticas públicas, que representam a materialidade da intervenção do Estado, ou o "Estado em ação" [...] ter presente as estruturas de poder e de dominação, os conflitos infiltrados por todo o tecido social e que têm no Estado o lócus da sua condensação (p. 5).

No plano concreto dessa abordagem, as políticas públicas, continua a autora, implicam "considerar os recursos de poder que operam na sua definição e que têm nas instituições do Estado, sobretudo na maquina governamental, o seu principal referente" (AZEVEDO, 2001, p. 5). Ainda segundo a autora, outro fator relevante na compreensão das políticas é a relação que existe entre as construções e as representações sociais das sociedades nas quais elas se dão, e as propostas de políticas públicas. Este fator concorre para os fundamentos que dão: origem, curso da implementação e desativação das políticas públicas. Assim tidas, "elas são construções informadas pelos valores, símbolos, 
normas, enfim, pelas representações sociais que integram o universo cultural e simbólico de uma determinada realidade" (AZEVEDO, 2001, p. 5).

As políticas de educação como políticas sociais de natureza pública são condicionadas pela natureza e pela ação do Estado, que define o caráter da sua intervenção. No caso concreto de Angola, depois da proclamação da independência, em 1975, o Estado fundado foi-lhe conferido as características de um Estado em transição para o Socialismo ${ }^{2}$, que aqui consideramos como Estado social, segundo a formulação de Paulo Bonavides (2013) no seu livro "Do Estado Liberal ao Estado Social”. Essa característica continua presente na Segunda República. No Estado que emergiu da independência, idealizou-se, assim foi nas sucessivas leis constitucionais, um "Estado de todas as classes, o Estado fator de conciliação, o Estado mitigador de conflitos sociais e pacificador necessário entre o trabalho e o capital." (BONAVIDES, 2013, p. 185). As igualdades a superar eram políticas e sociais, uma vez que à maior parte dos angolanos não lhes eram reconhecidos direitos políticos, e as políticas discriminatórias coloniais fomentavam a desigualdade social. Igualmente, no que diz respeito a sua ação,

[...] quando o Estado, coagido pela pressão das massas, pelas reivindicações que a impaciência do quarto estado faz ao poder político, confere, no Estado Constitucional ou fora deste, os direitos do trabalho, da previdência, da educação, intervém na economia como distribuidor, dita o salário, manipula a moeda, regula os preços, combate o desemprego, protege os enfermos, dá ao trabalhador e ao burocrata a casa própria, controla as profissões, compra a produção, financia a exportações, concede crédito, institui comissões de abastecimento, provê necessidades individuais, enfrenta crises econômicas, coloca na sociedade todas as classes na mais estreita dependência de seu poderio econômico, político e social, em suma, estende a sua influência a quase todos os domínios que dantes pertenciam, em grande parte, à área de iniciativa individual, nesse instante o Estado pode, com justiça, receber a dominação de Estado Social. (BONAVIDES, 2013, p. 186).

Como a pretensão era instituir em Angola um Estado socialista, trazemos as transformações apontadas por Bonavides, ilustrando o processo de transição de um Estado social ao Estado socialista.

Quando a presença do Estado, porém, se faz ainda mais imediata e ele se põe a concorrer com a iniciativa privada, nacionalizando e dirigindo indústrias, nesse

\footnotetext{
${ }^{2}$ Como presente na Lei Constitucional de 1975 e também nas teses e resoluções do primeiro congresso do MPLA de 1977. Esse aspecto será abordado no capitulo 2, quando for caracterizado o contexto da primeira República em Angola.
} 
momento, sim, ingressamos na senda da socialização parcial. É a medida que o Estado produtor puder remover o Estado Capitalista, dilatando-lhes a esfera de ação, alargando o número das empresas sob seu poder e controle, suprimindo ou estorvando a iniciativa privada, aí, então, correrá grave perigo toda a economia do Estado burguês, na consecução desse processo, já estaremos assistindo a outra transição mais séria, que seria a passagem do Estado social ao Estado socialista. (BONAVIDES, 2013, p. 186).

Foi nesse sentido que se buscou consolidar o Estado em Angola. Entre 1975 e 1991, o Estado nacionalizou a indústria e outros ramos da economia e definiu o modelo de economia centralizada para a sua ação. Reduzindo a índices insignificantes a atividade dos operadores privados, o Estado se torna o único operador econômico de facto. Assume-se também como provedor único dos serviços sociais, destacamos nele a educação, que é assumida por um sistema público. Devido à ausência de um proletariado de facto, se funda os ideais do Estado no dirigismo político de uma aliança operáriocamponesa, que, contudo, não se efetiva, sendo a assunção dos negócios do Estado assumidos, com um poder maior com o passar dos anos, por uma elite da nova classe dirigente. Nessa realidade, apesar da pretensão formal do Estado social e de algumas ações concretas do Estado, essa forma de Estado, a qual Bonavides confere "do ponto de vista doutrinário a valoração máxima e essencial” (p.187), em Angola não consegue agregar à sua ação os atributos essenciais para essa valoração máxima que seriam "a coordenação e colaboração, amortecer a luta de classes e promover, entre os homens, a justiça social, a paz econômica" (BONAVIDES, 2013, p. 187).

Nesse sentido, foi natural a interrupção do projeto do Estado socialista, que para além da ação do Estado não agregar os atributos acima explicitados, é também resultado de várias dinâmicas políticas e econômicas que se dão no decurso da edificação desse Estado. Essas dinâmicas são pontualmente consideradas nos capítulos subsequentes.

Constitucionalmente, esse Estado é superado pelo Estado democrático de direito, adoptado em 1991. Essa realidade reconfigura, no plano formal, os atores políticos, os direitos dos cidadãos e o sentido da realização da economia, o que também altera o modo de produção das políticas públicas, que contam não apenas com a ação da sociedade civil, mas também com a dos "movimentos globalizadores" presentes nas relações multilaterais desenvolvidas. São desenvolvidas, também nesse contexto, as premissas para a institucionalização de um Estado constitucional. É nessa perspectiva de Estado que se 
desenvolvem os princípios segundo os quais as políticas públicas devem essencialmente visar a efetivação dos direitos.

No Estado constitucional, parafraseando Liberati (2012), a vontade do governante é substituída pela vontade geral expressa na lei, conferindo a primazia do poder legislativo sobre o executivo, submetendo, assim, o poder estatal à ordem jurídica. Nesse Estado, se verifica "a regra maior da supremacia da Constituição (Vorrang der Verfassung) expressa a obrigatoriedade de vinculação dos poderes públicos, inclusive do legislador, às normas e princípios estabelecidos pela Constituição” (LIBERATI, 2012, p. 53, grifos do autor).

Liberati (2012), ao debruçar-se sobre o "fim primeiro do Estado Constitucional", recorda que a razão de existir do Estado constitucional é a lei fundamental, que por razões históricas aborda a pessoa humana, seus problemas, suas necessidades, seu bemestar, suas realizações, para além de outros aspectos coletivos, como a proteção do meio ambiente, da construção da paz, da realização e autodeterminação dos povos, dentre outros. "Disso resulta que o Estado Constitucional deve salvaguardar, minimamente, uma vida digna para todas as pessoas; vale dizer que o fim do Estado Constitucional se resume na proteção e garantia de todos os direitos individuais e coletivos que resultam em valor a dignidade humana." (LIBERATI, 2012, p. 66). Com isso, deve o Estado proteger os direitos por meio de provisões legais e ações administrativas para que o dever de proteger e de promover direitos esteja presente nos vários órgãos do Estado (FONTE, 2013), sendo estes essencialmente os vários atores incumbidos pelo Estado da missão de desenvolver atividades e serviços públicos, a fim de prover os direitos previstos na lei constitucional.

Para a educação como política pública social, a expectativa nesta realidade social é a contínua garantia do acesso de todos à educação, como tarefa dos Estados, e também a elevação da natureza de educação oferecida a estes que acedem à escola. Reivindica-se uma educação escolar que se enquadra na pensada por Anísio Teixeira, a que se propõe “a visar não a especialização de alguns indivíduos, mas a formação comum do homem e a sua posterior especialização para os diferentes quadros de ocupações, em uma sociedade moderna e democrática.” (TEIXEIRA, 1989, p. 436). Há também o discurso crescente 
sobre a necessidade de uma educação que se volta para a narrativa histórica dos angolanos e também "reinvente" a abordagem que a educação escolar empresta ao nacionalismo angolano, entendendo o nacionalismo como "a tomada de consciência pela nação, de sua existência, de sua personalidade e dos interesses de seus filhos." (TEIXEIRA, 1960, p. 207). É essencialmente volver a escola, parafraseando este autor, ao próprio país, focando-se no seu estudo, nas suas línguas, na sua história, na sua cultura e nos seus problemas e nas soluções dadas aos mesmos ou nas que não têm sido dadas. Essa perspectiva, se torna no contraponto ao movimento da globalização da educação como uma cultura educacional comum.

Afonso (2000), diz que a cultura educacional na perspectiva dos institucionalistas do sistema mundial (world institutionalists) tende a desenvolver sistemas educativos que visam esta cultura manifesta "num conjunto de recursos materiais disponíveis, partilhados por uma comunidade internacional (mundial) composta por Estados-nação autónomos estandardizados e a seguir orientações idênticas, isto é, a reproduzirem um certo “isomorfismo educacional” (p. 9).

Como principal argumento destes institucionalistas, continua Afonso, professam eles que as instituições nacionais, o próprio Estado incluso, não se desenvolvem autonomamente, sendo não mais do que modelados no contexto supranacional pelo efeito de uma ideologia mundial, entenda-se ocidental, dominante. Nessa perspectiva, a influência da referida comunidade internacional, veiculada nomeadamente por meio de organizações internacionais (OCDE, Unesco, Banco Mundial etc.) é vista como mais determinante no desenvolvimento dos respectivos sistemas educativos e na disseminação de orientações e categorias curriculares do que os fatores internos a cada um dos diferentes Estado-Nação (AFONSO, 2000, p. 9). Todavia, é pela agenda supranacional que se desenvolve o princípio da educação como direito humano fundamental a observar e que deve ser reconhecido e salvaguardado pelas diferentes agendas nacionais sobre educação.

Como conceito, o direito à educação é simultaneamente um direito humano per si e um meio indispensável para a realização de outros direitos (AMENESTIA INTERNACIONAL, 2013). Beiter (2006), argumentando sobre o reconhecimento da 
educação como direito humano fundamental, apresenta três visões para sustentar esse reconhecimento. A primeira é baseada no argumento da utilidade social, segundo a qual se afirma que um cidadão bem educado é tido como crítico para a manutenção das estruturas e dos ideais democráticos. A segunda é o argumento sobre o facto de a educação ser o pré-requisito para o desenvolvimento do indivíduo. A terceira é o argumento do bem-estar individual que lhe é conferido pela sociedade, o que concorre para o desenvolvimento da sociedade como um todo.

Esses atributos do direito à educação derivam das funções que o mesmo desempenha no indivíduo, na sua condição humana e como ser social conferido the a possibilidade de usufruir de outros direitos humanos. Um desses atributos é o que Beiter (2006) designa por "direito de empoderamento". O direito à educação comporta esta designação por conferir "aos indivíduos o controlo do curso da sua vida e em particular, controlo sobre (não uma mera proteção contra) o Estado" (BEITER, 2006, p. 28). Os direitos de empoderamento, continuando com Beiter, tornam possível aos indivíduos mudar o curso de suas vidas e também facilitam a sua participação política, econômica, social e da vida cultural, sendo assim considerado um dos pré-requisitos para o usufruto e para o exercício de outros direitos humanos.

Beiter (2006) realça ainda que o direito à educação como direito de empoderamento reconhece o potencial libertador da educação. Com esse potencial, o autor convoca a possibilidade que a educação confere aos indivíduos em pensar criticamente sobre a sua existência e potencializá-los a examinar com sagacidade necessária o curso das suas ações e fazer escolhas racionais informadas por esses exames. Acrescida ao potencial libertador, a educação nessa natureza de direito, confere também ao cidadão a capacitação política, uma vez que a liberdade da informação e de expressão, o direito à associação e reunião e o direito ao voto são garantidos por via desta particularidade do direito à educação.

Rabin (2007) também elabora uma relação de fatores que justificam o reconhecimento do direito à educação como direito humano fundamental. $\mathrm{O}$ seu primeiro argumento é que a educação providência: fundações à autonomia individual, liberdade e dignidade humana. $\mathrm{O}$ autor justifica suas afirmações advogando que o benefício da 
educação garantida pelo Estado nas sociedades modernas é fundamental para a salvaguarda e garantia da liberdade e da realização dessa mesma liberdade. Por um lado, é também pela educação que se constrói a dignidade humana no seu sentido extrínseco. Nas sociedades modernas, o indivíduo é avaliado essencialmente pelo seu grau de instrução, que representa a medida básica sobre o valor do indivíduo, as suas capacidades e o seu potencial em ser bem sucedido nas diferentes áreas da vida social. Quando essas capacidades, habilidade e potencial não se coadunaram com as expectativas da sociedade, o indivíduo tem sua dignidade afetada, por que é tido como não necessariamente útil para as exigências do quotidiano das sociedades modernas. Acrescenta-se também aos benefícios da educação a dignidade que ela confere à pessoa e a sua utilidade como instrumento de mobilidade social, uma vez que a aquisição de um diploma superior é, para muitos casos, a possibilidade única de transpor as barreiras na mobilidade social devido ao seu status econômico de baixa renda. Por outro lado, o direito à educação está relacionado à dignidade humana intrínseca devido a sua contribuição ao desenvolvimento individual e na elevação da autoestima alimentada pelo sentimento do valor individual nas suas relações sociais.

O segundo argumento de Rabin é o facto de ser essencial para a realização de direitos civis e políticos básicos por ser, antes de tudo, o principal veículo para a acumulação do conhecimento e da formação de ideias e opiniões. Como terceiro argumento, toma o ator a justificação nos princípios utilitários da educação ao considerar que a ela não somente beneficia o indivíduo, mas a sociedade como um todo. As crenças para sustentar essa visão sustentam que se um indivíduo não for educado, ele não somente priva-se a si próprio de seus direitos, como pode condicionar a legitimidade e os interesses das suas comunidades. A importância do direito à educação extravasa a educação como tal. Tomasevski (2001) cita que aqueles privados do direito à educação veem-se também privados de muitos outros direitos individuais, particularmente os relacionados ao emprego e à segurança social.

A educação age como um multiplicador, incrementando o gozo de todos direitos individuais e liberdades nos casos em que o direito a educação é efetivamente garantido, enquanto que priva as pessoas do gozo de muitos direitos e liberdades nos casos em que o direito á educação é negado ou violado (TOMASEVSKI, 2001, p.10). 
É por essas razões que o direito à educação, uma vez reconhecido como um direito humano, foi universalizado por meio de vários instrumentos internacionais e regionais, como declarações universais, convenções, tratados e constituições dos Estados $^{3}$. O princípio da mundialização que no seu âmbito formal preocupa-se com o facto de o direito à educação merecer o reconhecimento oficial dos Estados, manifesto na ratificação dos tratados, convenções, etc. No material, esse princípio visa a questão se o direito à educação é realizado de facto pelos Estados pela alocação dos recursos materiais e humanos devidos e outras condições conducentes à postulada realização (BEITER, 2006).

Pela sua formulação, o instrumento de partida é o artigo 13 da Convenção Internacional sobre os Direitos Econômicos, Sociais e Culturais de 1966. A formulação inserida neste documento é, para Beiter (2006), a mais importante formulação do direito à educação num acordo internacional. Para além desse, podemos mencionar também a Declaração Universal dos Direitos Humanos, a Convenção sobre os Direitos das Crianças; para o caso africano, realçamos a Carta Africana e a Carta Africana sobre os Direitos e Bem Estar da Criança.

Esses instrumentos surgem a partir do momento histórico em que a educação passa a ser vista, primeiro, como um direito humano, e a posterior como direito do cidadão e um dever do Estado, a fim de ultrapassar as barreiras implícitas e explicitas que concorriam para a negação da educação a muitos cidadãos em determinadas épocas da história da humanidade.

Fazendo uma caracterização histórica dos ideais e dos processos que influenciaram a adopção desses instrumentos, Beiter (2006) relata os fatores relevantes que marcaram o processo. Antes do Iluminismo do século XIX, a responsabilidade da educação era conferida aos pais e à Igreja. Contudo, com o advento das revoluções Americana e Francesa, a educação assume o seu caráter público. Compreendeu-se que a assumpção da educação pelo Estado seria a via para a garantia da disponibilidade e da

\footnotetext{
${ }^{3}$ Exemplos de instrumentos internacionais: Declaração Universal dos Direitos Humanos; Convenção sobre os Direitos Civis e Políticos; Convenção sobre os Direitos Econômicos, Sociais e Culturais; Convenção sobre os Direitos da Criança; Convenção Europeia para a Proteção dos Direitos Humanos e as Liberdades Fundamentais; Carta Africana sobre os Direitos e o Bem Estar da Criança; Carta Africana dos Direitos Humanos e dos Povos etc.
} 
acessibilidade da educação para todos. A educação pública era então tomada como um dos instrumentos para realizar os ideais de igualdade que sustentaram as revoluções citadas. Consideramos, pela sua gênese, a proclamação do direito à educação um imperativo ético porque a sua existência como regulador da relação social sobre o valor da educação e a sua disponibilidade para todos precede qualquer formalização legal.

Sen (2009), sobre o caráter ético dos direitos, afirma que as proclamações dos direitos humanos são fortes pronunciamentos sobre o que deveria realmente ser feito. Esses pronunciamentos requerem o reconhecimento de ações imperativas a realizar para que se efetivem os valores e princípios reconhecidos pelos direitos declarados. Esses pronunciamentos, o seu reconhecimento e as ações que deles se demandam moldam as relações sociais porque o conceito de "direito", como diz Birch (2007), é essencialmente sobre as relações humanas na sociedade. Como ilustração desse enunciado, o autor diz que se uma pessoa tiver direito a algo, os outros membros da sociedade têm a obrigação de respeitar esse direito, de o proverem e de não interferirem no gozo do mesmo. $\mathrm{O}$ caráter social do direito "é um aspecto essencial do conceito. A existência de direitos implica sempre obrigações da parte da pessoa ou do grupo de pessoas em posse do direito" (BIRCH, 2007, p. 178).

Ainda sobre o carácter social do direito e a do seu papel nas relações sociais, Sen (2009) e Birch (2007) também dialogam sobre os modos de institucionalização dos direitos. Birch alega que a base obvia de um direito é a existência de leis que os transformem em contratos vinculativos. Em Sen, por sua vez, temos que as abordagens sobre os direitos humanos nos tempos atuais já não se resumem a reivindicações, mas há muito se tornaram direitos legais presentes em vários instrumentos legais. A questão pública sobre os direitos humanos nos nossos dias é o convite para que se atualize a legislação sobre os mesmos e para se responder aos novos desafios que se vão impondo nas relações sociais. O desafio que faz, às abordagens contemporâneas dos direitos humanos, é centrar a questão "em legislação atual e não simplesmente em mais interpretações dos homens sobre as proteções legais já existentes” (SEN, 2009, p. 359).

$\mathrm{O}$ direito à educação, compreendido dessa maneira e estando inscrito em instrumentos que o tornam global e por outros de concepção e adopção local que 
reforçam a sua natureza reguladora nas relações sociais, desdobra-se em alguns elementos que traduzem a sua materialização. A Declaração Universal dos Direitos Humanos da ONU (2000), no ponto 1 do artigo XXVI, atesta que "todo ser humano tem direito à instrução. A instrução será gratuita, pelo menos nos graus elementares e fundamentais. A instrução elementar será obrigatória.” (ONU, 2000, p. 12).

Sobre o conteúdo da educação, essa declaração advoga uma orientada "no sentido do pleno desenvolvimento da personalidade humana e do fortalecimento do respeito pelos direitos humanos e pelas liberdades fundamentais." (ONU, 2000, p. 12). Percebe-se na declaração o não detalhamento dos aspectos como a gratuidade e a obrigatoriedade, o que pode induzir a múltiplas interpretações e permitir o livre arbítrio dos Estados em ressignificarem para os seus contextos e projetos políticos estes princípios. Todavia, à medida que a adopção desses princípios não correspondiam às expectativas da consagração do direito à educação, foram produzidos, em diferentes épocas, instrumentos complementares e atualizados sobre a natureza dos desafios, e também apresentando um melhor detalhamento sobre o que os princípios implicavam para a ação dos Estados.

A Convenção Internacional dos Direitos Econômicos e Culturais ${ }^{4}$, de 1966, definem, no artigo 13 (ONU, 1999) princípios do direito à educação (ver Quadro 1).

Esses traços essenciais do direito à educação são esmiuçados nos comentários ${ }^{5}$ feitos ao artigo 13 da convenção, artigo este que é considerado como o mais extenso e compreensivo artigo sobre o direito à educação na legislação internacional sobre os direitos humanos. Os comentários retomam os "4 $\mathrm{As}^{" 6}$ como os pilares do direito à educação, definidos por Tomasevsky (2001), que expressam a educação como direito, deve estar disponível, acessível, aceitável e adaptável. Para Tomasevsky, a contraparte dos direitos humanos é a sua conversão em obrigação para os governos, o que faz com que sempre que existirem direitos, como os da educação, haja necessariamente obrigações para os governos.

\footnotetext{
${ }^{4}$ Adoptado pela resolução n. 2.200-A (XXI) da Assembleia Geral das Nações Unidas, em 16 de dezembro de 1966 e entrou em vigor em 3 de janeiro de 1976.

${ }^{5}$ Committee on Economic, Social and Cultural Rights, General Comment 13, The right to education (Twenty-first session, 1999), U.N. Doc. E/C.12/1999/10 (1999), reprinted in Compilation of General Comments and General Recommendations Adopted by Human Rights Treaty Bodies, U.N. Doc. HRI/GEN/1/Rev.6 at 70 (2003).

${ }^{6}$ Do inglês Available, Acessible, Acceptable e Adaptable.
} 
Quadro 1: Princípios do direito à educação

$\S$ Os Estados-partes no presente pacto reconhecem o direito de toda pessoa à educação. Concordam em que a educação deverá visar ao pleno desenvolvimento da personalidade humana e do sentido de sua dignidade e a fortalecer o respeito pelos direitos humanos e liberdades fundamentais. Concordam ainda que a educação deverá capacitar todas as pessoas a participar efetivamente de uma sociedade livre, favorecer a compreensão, a tolerância e a amizade entre todas nações e entre os grupos raciais, étnicos ou religiosos e promover as atividades das Nações Unidas em prol da manutenção da Paz.

$\S$ Os Estados-partes do presente Pacto reconhecem que, com o objetivo de assegurar o pleno exercício desse direito:

1. A educação primária deverá ser obrigatória e acessível gratuitamente a todos.

2. A educação secundária em suas diferentes formas, inclusive a educação secundaria técnica e profissional, deverá ser generalizada e tornar-se acessível a todos, por todos os meios apropriados e, principalmente, pela implementação progressiva do ensino gratuito.

3. A educação de nível superior deverá igualmente tornar-se acessível a todos, com base na capacidade de cada um, principalmente, pela implementação progressiva do ensino gratuito.

4. Dever-se-á fomentar e intensificar, na medida do possível, a educação de base para aquelas pessoas não receberam educação primária ou não concluíram o ciclo completo de educação primária.

5. Será preciso prosseguir ativamente o desenvolvimento de uma rede escolar em todos os níveis de ensino, implementar-se um sistema adequado de bolsas de estudo e melhorar continuamente as condições materiais do corpo docente.

6. Os Estados-partes no presente Pacto comprometem-se a respeitar a liberdade dos pais e, quando for o caso, dos tutores legais, de escolher para seus filhos escolas distintas daquelas criadas pelas autoridades públicas, sempre que atendam aos padrões mínimos de ensino prescritos ou aprovados pelo Estado, e de fazer com que seus filhos venham a receber educação religiosa ou moral que esteja de acordo com suas próprias convicções.

7. Nenhuma das disposições do presente artigo poderá ser interpretada no sentido de restringir a liberdade de indivíduos e de entidades de criar e dirigir instituições de ensino, desde que respeitados os princípios enunciados no parágrafo 1do presente artigo e que essas instituições observem os padrões mínimos prescritos pelo Estado.

Fonte: ONU (1999) 
Os "4 As" como elencados por Tomasevsky constituem-se então nas obrigações impostas aos governos na busca da efetivação do direito à educação no contexto das suas políticas de educação. A disponibilidade incorpora duas obrigações diferentes. A primeira resulta do facto de o direito à educação ser um direito civil e também político, o que requer que os governos permitam a criação de instituições de educação detidas por atores não estatais. Ao passo que como direito social e econômico, o direito à educação requer que o governo crie esses estabelecimentos de educação ou, então, acrescenta a esses outros mecanismos para tornar a educação disponível. Pelos comentários ao artigo 13, a disponibilidade exige a gratuidade da educação oferecida e também a existência de prédios escolares em número e condições de atender à população estudantil. É também de se garantir a existência de uma cobertura docente e condições materiais condignas para o trabalho da escola.

Quanto ao acesso, a autora diz que tem diferentes definições em função do nível de escolaridade, impõe a obrigação ao governo de garantir o acesso à educação para todas as crianças na idade da educação obrigatória. Para tal, essa educação deve ser grátis para esse nível de educação. É preciso que não discriminem ninguém quando das buscas dos serviços da educação. Raça, gênero, origem étnica, condição econômica, credos religiosos e opções políticas não devem servir de critérios de seleção para o benefício da educação provida pelo Estado.

Para a não discriminação, os comentários realçam dois aspectos essenciais. $\mathrm{O}$ primeiro é sobre a não descriminação e o tratamento igual. A não discriminação não se sujeita à implementação progressiva, nem à disponibilidade de recursos, dado que a mesma aplica-se integral e imediatamente a todos os aspectos da educação e observa todas as formas de discriminação internacionalmente reconhecidas. A adopção de medidas temporárias e especiais destinadas a lidar com a disparidade do gênero ou de outros grupos desfavorecidos não se constitui em violação ao direito da não descriminação, salvo se as mesmas medidas significarem a manutenção de tratamento desigual entre os diferentes grupos. É ainda considerado discriminação as profundas 
disparidades nas políticas de financiamento que resultam numa qualidade de educação diferenciada para as pessoas a residirem em diferentes áreas geográficas.

O segundo aspecto é sobre a liberdade educacional, solicitando se aos Estados a respeitarem a liberdade dos pais e dos encarregados de educação em garantir a educação religiosa e moral para os seus filhos, em conformidade com as suas convicções. Todavia, na escola pública, a educação sobre religiões não deve ser dirigida à doutrina de uma religião particular por ferir o princípio da laicidade, mas sim a um entendimento geral sobre história das religiões.

Mas além de disponibilizar a educação e também garantir o acesso a ela, os governos são obrigados a cumprir com o princípio da aceitabilidade que se associa à qualidade. Impõe-se aos governos a conferir qualidade à educação que o mesmo oferece porque "a educação [...] é um processo interativo. Ela envolve o aprendizado. O simples facto de frequentar instituições educativas, sem efetivar o aprendizado, não equivale a educação. $\mathrm{O}$ direito à educação deve assim ser entendido como o direito no sentido do direito a ser educado" (BEITER, 2006, p. 20). Essa preocupação da qualidade da educação pode ser encontrada em Adeyinka (2006), que realça a existência de uma crescente preocupação sobre a relevância da educação nos dias de hoje, uma vez que, no plano instrumental, ela tem criado uma nova onda de desempregados que resultam da incapacidade da educação proporcionada em conferir competências necessárias para as demandas do mercado. Muitos dos diplomados chegam ao mercado sem as competências requeridas para o exercício das profissões ou funções nas quais são "treinados" na escola. Por não satisfazerem as necessidades do mercado de trabalho, esses diplomados são preterido por outros julgados mais habilitados, em alguma situações em Angola, por expatriados que melhor respondem as exigências dos empregadores. Para uma educação que responda ao seu plano instrumental, requer-se que sejam disponibilizados para as escolas professores devidamente qualificados, manuais atualizados e para todos, que a língua de instrução seja a domínio e da realidade cultural dos alunos e, também, que se tome os alunos como atores no processo educativo, isto é, a salvaguarda da sua condição de sujeito etc. O conteúdo da educação e os atos pedagógicos devem ser relevantes para os propósitos da educação que também esteja ajustada às necessidades de todos, salvaguardando as demandas dos diferentes grupos que buscam a escola, as minorias em 
particular. É também obrigação garantir o direito à educação às crianças com deficiências e necessidades especiais de aprendizagem, o que respeita o princípio da adaptabilidade da educação para responder a demanda de direito. A educação, como processo deve ser flexível para se ajustar às necessidades dos alunos, seja pela sua realidade ambiental, social e/ou econômica.

A satisfação do direito à educação demanda também o caráter universal, obrigatório e gratuito. O universal implica que toda a criança abrangida pela idade desse nível deve ser garantido o acesso e a disponibilidade em frequentar um estabelecimento escolar para se beneficiar da educação oferecida. O obrigatório alude que toda criança, em idade escolar, deve frequentar a escola, e a ninguém é conferido o direito de impedi-la de frequentar a escola. Por sua vez, o gratuito estabelece que a educação primária deve ser oferecida sem qualquer custo para as crianças ou para os seus pais ou encarregados de sua educação.

Esses princípios induzem obrigações aos Estados que emanam da ratificação dos instrumentos internacionais sobre os direitos humanos, e marco no qual os Estados assumem o compromisso de os respeitar independentemente do governo em função. Desta ratificação deve resultar o reconhecimento do direito pelos Estados e o início de ações concretas para a completa efetivação do direito à educação. Como elucidado pelos comentários ao artigo 13 da Convenção ${ }^{7}$, esse direito, como todo direito humano, impõe três níveis de obrigações aos Estados. Nomeadamente, a obrigação de respeitar requer que os Estados evitem atos e medidas que podem condicionar ou privar o gozo do direito em causa; a de proteger que implica a tomada de medidas, pelos Estados, para prevenir que terceiros interfiram no benefício do direito; a obrigação de cumprir que incorpora a obrigação de facilitar e a de prover. O Estado facilita a efetivação do direito quando toma medidas que permitem e auxiliam indivíduos e comunidades a se beneficiarem do direito, e quando o Estado providencia que o direito se materializa, está a observar a obrigação de prover.

\footnotetext{
${ }^{7}$ Committee on Economic, Social and Cultural Rights, General Comment 13, The right to education (Twenty-first session, 1999), U.N. Doc. E/C.12/1999/10 (1999), reprinted in Compilation of General Comments and General Recommendations Adopted by Human Rights Treaty Bodies, U.N. Doc. HRI/GEN/1/Rev.6 at 70 (2003).
} 
Também sobre as obrigações para garantir o direito à educação, a Unesco e o Unicef (2007) compilaram dos principais instrumentos internacionais sobre os direitos humanos as obrigações que se garanta o direito. No Quadro 2 resumem-se estas obrigações.

É devido ao reconhecimento desses atributos do direito à educação e ao modo como os mesmos se relacionam aos fins das políticas em educação que definimos como objetivo do estudo a compreensão de como é articulada a política pública em educação, especificamente no seu conteúdo, na efetivação do acesso e do atendimento como garantias do direito à educação em Angola. Considerando-se que o direito à educação é por regra assumido nos discursos políticos, somente, como a garantia do acesso, independentemente da natureza da educação proporcionada aos alunos uma vez no sistema de educação.

\section{Quadro 2: Obrigações para cumprimento do direito à educação}

1. Prover educação primária obrigatória e grátis

2. Desenvolver modalidades da educação secundaria que estejam disponíveis e acessíveis a todos, e introduzir medidas para prover educação gratuita e assistência financeira no caso de necessidades.

3. Tornar acessível a informação e orientação sobre educação profissional.

4. Introduzir medidas para encorajar a assistência regular as aulas e reduzir os índices de abandono escolar.

5. Prover educação na base de igualdade de oportunidades.

6. Garantir o respeito pelo direito à educação sem qualquer forma ou base de descriminação.

7. Garantir um sistema de educação inclusivo.

8. Prover acomodação aceitável e apoiar medidas para garantir que as crianças com deficiências têm o acesso efetivo e beneficiam da educação conducente a sua completa integração social.

9. Garantir padrões adequados de vida para o desenvolvimento físico, mental, espiritual, moral e social.

10. Prover a proteção e assistência para garantir o respeito pelos direitos das crianças na condição de refugiadas ou de exiladas.

11. Prover a proteção da exploração econômica e de trabalho que interfiram com a educação. 
Fonte: UNESCO e UNICEF (2007)

O foco temporal será a segunda República constituída em 1991, com a institucionalização pela constituição de uma nova orientação do Estado, isto é, a adopção de um Estado democrático de direito, fazendo o recorte até 2012, período em que se generaliza a reforma educativa para todo sistema da educação. E para compreendermos o processo histórico da construção dos desafios determinados na política educativa, faremos a abordagem de dois períodos marcantes na história da educação escolar formal em Angola. Nomeadamente o período colonial, com o recorte entre 1960-1974, período relevante para a luta pela autodeterminação dos povos angolanos e da busca dos direitos sociais, civis e políticas; o período da primeira República (1975-1991), em que vigorou a tendência de governo socialista.

Para a abordagem das pretensões desse estudo, a metodologia, sustentamo-nos em documentos e referentes bibliográficos. Na categoria de documentos, analisamos alguma legislação de cada período abordado no estudo, isso também serviu para situar alguns ideais políticos formalmente vigentes nessas realidades. É crença nossa que a análise da educação e das políticas públicas que a sustentam precisa considerar o ambiente econômico, político e o quadro legislativo em que ela se insere.

As constituições de cada República são analisadas por estabelecerem os princípios gerais que informam a legislação ordinária destinada a prescrever as ações e atos de governo. A virtude de uma constituição, quando se verificar uma estabilidade política, deve-se a razão das suas provisões constitucionais articularem os maiores princípios da sociedade e também por estes princípios sujeitarem a sua mudança a processos longos (NAPIER, 2005). A legislação ordinária, as leis sobre educação no âmbito desse estudo, capturam os valores do tempo e do local (NAPIER, 2005) e assumem uma forma de política educacional (MEAD, 2009). Mesmo quando não implementadas, elas podem desempenhar um papel relevante ao facilitarem o reforço do caráter social atribuído à escola (STROMQUIST, 2007).

É nesse sentido que sustentamos o crédito de buscarmos na legislação educacional, como decretos, leis e despachos ministeriais, os valores e princípios nelas 
definidos a fim de aferirmos, por um lado, a existência da declaração da educação como um direito do cidadão e, por outro, como os atributos conferidos à educação, os seus objetivos bem como os seus princípios definidos, concorrem para o enriquecimento da sua condição de direito. Na verdade, a expectativa foi a de apreender do quadro legal da educação, como fundamento da política educacional, as intenções da ação do Estado sobre a natureza da educação a proporcionar aos cidadãos, e as condições objetivas para a sua efetivação. É também na legislação que nos situamos para a compreensão da natureza do Estado e a sua abordagem ao princípio da dignidade humana que o exige a promover, proteger e garantir os direitos fundamentais dos cidadãos na sua condição humana. É por intermédio dela também que descortinamos, pelo menos no plano formal, a forma como o Estado propõe-se a exercer o seu poder soberano.

Também nos documentos, analisamos os oficiais (programas de governo e relatórios) produzidos por essas entidades como o Ministério da Educação e o Instituto de Estatística a fim de compreendermos a representação estatística da oferta da educação na vigência dos governos de cada República visada. Apesar de a validade da produção estatística colonial ser contestada (RODNEY (1982), KI-ZERBO (1990), ADAYINKE (2006), FERREIRA (1974)) devido a um suposto branqueamento dos dados em função dos movimentos internacionais a favor da independência dos territórios coloniais e também devido à validade da estatística na República de Angola ser questionada devido à fraca capacidade instalada, quer humana como material, para a recolha e tratamento da informação estatística, adoptamos neste estudo estes documentos por serem os únicos indicadores existentes e também por os mesmos apresentarem a visão oficial dos respectivos governos. Além do mais, esses documentos, por serem produzidos dentro de um sistema de governo, conferem aos dados e à informação neles contidos um determinado grau de representatividade em razão de sua abrangência territorial. $O$ foco no tratamento dessa categoria foi a tentativa da apreensão e compreensão das ideias e das ações dos governos e as razões que justificavam as mesmas.

Analisamos também vários documentos produzidos pelos diversos atores identificados no processo em análise, mas a ênfase recaiu para as organizações multilaterais, como Banco Mundial, Unesco e Unicef por serem os principais mentores da agenda da educação universal, salvaguardadas as abordagens e os fins defendidos por 
cada um desses atores. Como buscamos a gênese das ideias associadas ao direito à educação na política da educação, centramos a análise nas declarações de princípios das organizações supranacionais e as respectivas agendas globais sobre a educação. Para a ação local, privilegiamos os documentos produzidos nas fases de avaliação das condições concretas do país para a análise do perfil do país na ótica dessas organizações, os relatórios produzidos durante o processo de negociação da natureza e do âmbito da atuação desses atores no sistema de educação e, também, a avaliação desses atores sobre a implementação dos seus programas.

Apesar deste estudo não ser de caráter etnográfico, sentimos que a nossa condição de ator, professor e gestor, no sistema de educação influenciou a narrativa sobre a educação em Angola, uma vez que "a maneira como um pesquisador encara a política educacional influencia o tipo de investigação que se propõe a realizar" (MAINARDES, 2009, p.4). É assim que o sentido da análise da política foi o de associar ao fim de efetivar o direito à educação. Emprestamos ao trabalho a abordagem "êmica" que, segundo Rosa e Orey (2012) permite fazer corresponder a visão do "eu" em direção ao "nosso" para entender as manifestações que ocorrem no processo em estudo. Nessa perspectiva, a nossa pretensão é desenvolver um quadro de compreensão da política da educação a partir da nossa condição de participante, mesmo que não do processo de tomada de decisão na sua adopção, mas como agente para a sua efetivação, o que pode manifestar a nossa própria compreensão influenciada pela cultura e pela história (MORRIS et al., 1999) dos locais e dos contextos. Diante dessa perspectiva, vimo-nos, como descrito por Rosa e Orey, na situação de pesquisadores, investigadores e educadores que acreditam em factos como a origem cultural e linguística, os valores sociais, a moral e os estilos de vida influenciam a ideias e concepções sobre os fins da educação.

Relativo à estrutura, este trabalho está divido em duas partes. Na primeira parte, constituída pelos capítulos 1 e 2, fazemos uma caracterização histórica da questão em estudo para se compreender o processo da constituição dos obstáculos para a efetivação da educação e a natureza dos desafios advindos dessa realidade. No capítulo 1, abordamos a educação colonial como marco pioneiro da construção de um sistema de educação escolar formal em Angola, na condição de território ultramarino de Portugal. 
No capitulo 2, analisamos a educação na primeira República para aferir como o sistema público encarregado de democratizar a educação e também de responder às demandas da época se prestou a efetivar uma educação assente nos princípios do direito à educação.

Na segunda parte, no capítulo 3, tratamos da política educacional atual, levando em consideração os obstáculos historicamente construídos, as demandas da realidade atual e as propostas para se efetivar a educação como direito, centrando sempre a análise no acesso e no atendimento. No capítulo 4, visamos a compreensão da gênese das ideias, os atores e suas ações que informam a política educacional e, também, como as questões relativas ao direito à educação se manifestam nessas ideias e ações. 


\section{A EDUCAÇÃo COMO DIREITO NA POLÍTICA EDUCACIONAL NO PERÍODO COLONIAL (1960-1974)}

No período que compreende este capítulo vigorava em Portugal o Estado Novo (da Constituição de 1933 até 25 de abril de 1974), regime político definido, conforme Rodney (1982) e Ferreira (1974), como autoritário, autocrata, corporativista, fascista e colonialista. Esse regime é também chamado de "salazarismo" devido aos ideais de governo de António Oliveira Salazar que governou Portugal, como primeiro ministro entre julho de 1932 a setembro de 1968. Na sua relação com as colônias e com os povos nativos, a sua principal marca de governo está no Decreto n. 18.570, de 8 de julho de 1930 (PORTUGAL, 1930), na dupla qualidade de ministro das finanças e das colônias. Esse instrumento, o "Acto Colonial", que define a sua política ultramarina ao longo da sua governação, agrava as situações de discriminação, de exploração e de dominação a que as populações nativas estavam sujeitas. Nesse "Acto Colonial", diz-se que Portugal "tem a função histórica e essencial de possuir, civilizar e colonizar domínios ultramarinos e de exercer a influência moral" (ponto I). Sobre o "indígena", "o Estado promulga para os indígenas, onde seja ainda primitiva a rudeza, estatutos especiais que, orientados ainda assim pelo direito público e privado de Portugal, contemporizem com os usos e costumes que não destoem essencialmente da moral e dos princípios de humanidade." (ponto I). Por isso,

\footnotetext{
Nas colônias atender-se-á ao estado de evolução dos povos nativos, havendo estatutos especiais dos indígenas que estabeleçam para estes, sob a influência do direito público e privado português, regimes jurídicos de contemporização com os seus usos e costumes individuais, domésticos e sociais, que não sejam incompatíveis com a moral e com os ditames de humanidade. (PORTUGAL, 1930, art. 22).
}

Os estatutos especiais aludidos nestes documentos ganham corpo com o Decretolei n. 39.666 de 1954 (PORTUGAL, 1954), que define como "indígena" os nativos africanos que não exibissem hábitos da cultura portuguesa e dominassem a língua 
portuguesa. Atribui-se neste estatuto o Estado português o "compromisso" de melhorar a condição humana dos povos nativos. Declara a lei que

[...] o Estado promoverá por todos os meios o melhoramento das condições materiais e morais da vida dos indígenas, o desenvolvimento das suas aptidões e faculdades naturais e, de maneira geral, a sua educação pelo ensino e pelo trabalho para a transformação dos seus usos e costumes primitivos, valorização da sua atividade e integração ativa na comunidade mediante acesso à cidadania. (PORTUGAL, 1954, art. 4).

O ensino pensado para garantir a educação destes povos nos princípios da educação colonial e também das suas necessidades ditas pelos seus projetos de colonização fica assim definido:

O ensino que for especificamente destinado aos indígenas deve visar aos fins gerais da educação moral, cívica, intelectual e física, estabelecidos nas leis e também à aquisição de hábitos e aptidões de trabalho, de harmonia com os sexos, as condições sociais e as conveniências das economias. (PORTUGAL, 1954, art. 6).

É o pensamento espelhado no ato colonial que molda a ação de Portugal nas suas relações com os nativos africanos e com organizações e países estrangeiros que se engajam na luta da autodeterminação dos povos colonizados, e também no respeito dos princípios e valores defendidos pelas Cartas e tratados internacionais e que ganham o caráter universal. Portugal adere às Nações Unidas em 1955, e depois de solicitado pela ONU a declarar se administrava territórios que entravam na categoria dos definidos no artigo $73^{8}$ da carta da ONU, Portugal responde que não administra qualquer território na

\footnotetext{
${ }^{8}$ Os membros das Nações Unidas, que assumiram ou assumam responsabilidades pela administração de territórios cujos povos não tenham atingido a plena capacidade de se governarem a si mesmos, reconhecem o princípio de que os interesses dos habitantes desses territórios são da mais alta importância, e aceitam, como missão sagrada, a obrigação de promover no mais alto grau, dentro do sistema de paz e segurança internacionais estabelecido na presente Carta, o bem estar dos habitantes desses territórios e, para tal fim, se obrigam a: a) assegurar, com o devido respeito à cultura dos povos interessados, o seu progresso político, econômico, social e educacional, o seu tratamento equitativo e a sua proteção contra todo abuso; b) desenvolver sua capacidade de governo próprio, tomar devida nota das aspirações políticas dos povos e auxiliá-los no desenvolvimento progressivo de suas instituições políticas livres, de acordo com as circunstâncias peculiares a cada território e seus habitantes e os diferentes graus de seu adiantamento; c) consolidar a paz e a segurança internacionais; d) promover medidas construtivas de desenvolvimento, estimular pesquisas, cooperar uns com os outros e, quando for o caso, com entidades internacionais especializadas, com vistas à realização prática dos propósitos de ordem social, econômica ou científica enumerados neste Artigo; e e) transmitir regularmente ao Secretário-Geral, para fins de informação, sujeitas às reservas impostas por considerações de segurança e de ordem constitucional, informações estatísticas ou de outro caráter técnico, relativas às condições econômicas, sociais e educacionais dos territórios pêlos
} 
categoria dos definidos no artigo 73. Os territórios em questão são os "geograficamente separados e que tinham diferenças a nível étnico ou cultural em relação ao país administrante e sobre os que se encontravam numa situação de subordinação administrativa, política, jurídica, e econômica ou histórica em relação à metrópole" (SANTOS, 2011, p. 67).

$\mathrm{Na}$ sua resposta, Salazar, na condição de chefe do governo, afirma que "as províncias ultramarinas portuguesas não têm vocação para a independência separada [...] o governo português se arroga o exclusivo de interpretar e aplicar a sua ordem constitucional e que neste domínio não admite interferências alheiras" (SILVA, 1995, p. 5-6). Essa atitude Portuguesa é antecedida com a Lei n. 2.066 de 27 de maio de 1953, quando as colônias portuguesas passam a "Províncias Ultramarinas", em resposta a vaga de independência de territórios coloniais. Contudo, essa atitude de Portugal não impediu a Assembleia Geral das Nações Unidas de aprovar em 14 e 15 de dezembro de 1960 três resoluções (a 1514(XV), a 1541(XV) e a 1542(XV)) condenando a política colonial portuguesa.

Sobre o conteúdo dessas resoluções, retomamos o texto "Os 'ventos de mudança' e a descolonização: a ONU e as resoluções da Assembleia Geral de dezembro de 1960", de Aurora Almeida e Santos (2011). Para a autora, "estas resoluções estavam estreitamente relacionadas com a recusa Portuguesa em aceitar as decisões da ONU sobre o fornecimento de informação das condições de vida nos seus territórios não autônomos" (SANTOS, 2011, p. 62). Apesar de não se fazer menção direta a Portugal, Santos afirma que o objetivo das resoluções era a reprovação do pensamento e do argumento de Portugal que apresentava as colônias sob seu domínio como províncias ultramarinas, sendo que, na ótica da autora, as resoluções encararam a questão mais do ponto de vista político que jurídico. O espírito da resolução, como o vemos, era a obrigatoriedade das potências coloniais em transmitir as informações sobre os territórios enquanto estes não atingissem o completo autogoverno, como solicitado no artigo 73 da Carta.

quais são respectivamente responsáveis e que não estejam compreendidos entre aqueles a que se referem os Capítulos XII e XIII da Carta. 
Nas resoluções, continuando com Santos (2001), elabora-se uma lista de territórios inclusos na categoria de não autônomos, constando nela Cabo Verde, Guiné, São Tomé e Príncipe, Angola, Moçambique, São João Baptista de Ajudá ${ }^{9}$, Goa, Macau e Timor. "Esta enumeração dos territórios portugueses representou a assunção de um papel mais ativo das Nações Unidas relativamente à questão colonial Portuguesa" (SANTOS, 2011, p. 68). Conclui a autora, sobre as resoluções, que as mesmas "implicaram um ruptura decisiva no olhar da ONU quanto ao colonialismo, resultante da consciência de que as pressões políticas seriam mais eficazes do que a abordagem técnica e jurídica." (p. 68).

Em 1968, Marcelo Caetano chega ao poder como chefe do governo português, governo que é destituído pelo golpe militar de 25 de abril de 1974. Sobre as colônias (províncias ultramarinas pelo estatuto deste período), Marcelo Caetano defendia a diminuição da intervenção de Portugal, ao mesmo tempo empenhava-se na criação de quadros locais a que pudesse ser entregue o poder. Não deveria, na sua ótica, o poder estar nas mãos das populações brancas hostis a Portugal, nem nas dos movimentos de libertação (tidos por ele e pelo seu governo como subversivos), temendo uma expulsão da população branca de África. Ao contrário do pensamento da missão histórica e da defesa dos interesses económicos, Caetano justificava a guerra nas colônias como a defesa dos interesses das populações brancas, há muito instaladas em África.

Quer a política de Salazar como a do seu sucessor, Caetano, não reconheciam o direito de autodeterminação dos povos por eles colonizados. Reiteramos que a autodeterminação dos povos colonizados foi consagrada na Carta da Organização das Nações Unidas de 1945, precisamente no artigo 73 (ONU, 2001). É a partir desse momento que se incrementa a pressão internacional sobre Portugal para a autodeterminação dos territórios coloniais. Em resposta, Portugal busca mecanismos para a manutenção do status quo levando a cabo alterações na legislação, uma reformulação doutrinária e medidas de fomento à economia em Angola e em Moçambique. (CASTELO, 2007).

\footnotetext{
${ }^{9}$ Atualmente é conhecida por Ouidah, Whydah ou Judá. É uma cidade localizada na costa ocidental africana na atual República do Benin.
} 
Como exemplo dessas medidas, Castelo (2007) diz que em 1951, na ocasião da revisão da constituição da República Portuguesa, é apresentada a proposta da revogação do ato colonial, sendo, no entanto, integrado no texto constitucional e feitas algumas alterações que se ajustassem às pretensões da época. Por exemplo, o termo "colônia" foi substituído por "províncias ultramarinas" buscando atingir o seu ideal de unidade nacional. A assimilação continuou a ser o fundamento das relações sociopolíticas, e o estatuto do indígena de 1954, apesar de revisto, continuava a negar a cidadania a maioria da população de Angola, no plano formal e o pleno gozo dos direitos. Os assimilados, aqueles nativos que se conformassem com as exigências legalmente definidas, eram "uma ínfima minoria, porque nunca houve vontade de criar elites no ultramar, através de uma aposta consequente no alargamento do sistema de ensino aos africanos". (CASTELO, 2007, p.108).

Todavia, em 1960 e nos anos subsequentes, uma série de acontecimentos altera o contexto político nas colônias. Por exemplo, e como compilados por Castelo (2007), no ano de 1960, 17 países africanos conquistaram a independência, reforçando o poder de pressão do grupo de países africanos e asiáticos na ONU. Em 1961, em 22 de janeiro, dáse o assalto ao paquete "Santa Maria"; em 4 de fevereiro, o assalto às cadeias de Luanda (Angola) e a tentativa de libertação dos presos. Em 15 de março acontecem os ataques armados em larga escala orquestrados pela União dos Povos de Angola (UPA) ${ }^{10}$ no norte de Angola. Na Índia dá-se a ocupação de Goa, Damão e Diu pela União Indiana em dezembro.

Em reação a esse cenário, Portugal vê-se forçado a promulgar várias medidas a fim de eliminar as formas de exploração, ainda presentes nas colônias, como o contrato ${ }^{11}$,

\footnotetext{
10 A Frente Nacional de Libertação de Angola (FNLA) é um movimento político fundado em 1954, com o nome de União das Populações do Norte de Angola (UPNA), assumindo em 1958 o nome de União das Populações de Angola (UPA). Em 1961, a UPA e um outro grupo anticolonial, o Partido Democrático de Angola (PDA), constituíram conjuntamente a FNLA. A UPA, enraizada principalmente entre os Bakongo, mas com aderentes também entre os Ambundu e os Ovimbundu, iniciou a sua luta armada na região do norte de Angola em 15 de Março de 1961, nomeadamente no concelho do Uíge estendendo-se mais tarde para o sul, até à atual província do Bengo. Ela teve como retaguarda de luta o ex-Congo Belga, atual República Democrática do Congo, a seu tempo liderada pelo falecido General Mobutu Sese Seko.

${ }^{11}$ Consolidados os impedimentos colocados ao trafico de homens escravizados, Portugal desenvolve outra forma de exploração da mão-de-obra africana, o trabalho contratado. Apesar de se proibir o trabalho forçado ou obrigatório, os mesmo era pratica comum em Angola. Os trabalhadores eram deslocados de suas
} 
as culturas obrigatórias ${ }^{12}$ e as formas de discriminação, como o estatuto do indígena ${ }^{13}$. Outra ação consta da revisão de 1971, que consagra formalmente um princípio de autonomia progressiva para Angola e Moçambique, apesar de o grosso da população desses territórios continuarem sem direitos políticos, que se mantém como privilégio dos cidadãos "brancos" europeus e os nascidos em Angola. Entretanto, como demonstrado num relatório referenciado por Castelo (2007), o então Ministro do Ultramar denunciava irregularidades praticadas contra a população nativa e na esperada convivência e harmonia entre Europeus e nativos. A discriminação racial era manifesta nos castigos corporais aplicados aos trabalhadores por patrões, autoridades administrativas e policiais, pelas rusgas policiais contra os nativos resistentes aos contratos, remissos aos impostos e sem patrão. Relatava-se também a discriminação salarial e entraves no acesso ao emprego condigno.

Esse "apego" de Portugal às colônias pode ser traduzido pelas palavras de Ferreira (1974) ao observar que as colônias dos países europeus eram uma espécie de extensão territorial destes países. Com os sinais de um capitalismo industrial em formação, a possessão dessas colônias era vital para as economias domésticas, subdesenvolvidas, como era o caso de Portugal. Neste país, a importância das colônias resume-se em

[...] primeiro, elas eram a garantia de um mercado protegido que fornecia matérias prima a baixo preços em relação as cotações do mercado e comprando os produtos portugueses, no geral, de baixa demanda internacional. Segundo, os seus rendimentos nas transações externas oriundas das exportações e serviços aliviaram o crônico déficit na balança de negócios de Portugal (FERREIRA, 1974, p. 33).

Respeitante à política educacional, a educação proporcionada em Angola pelas autoridades coloniais de Portugal é geralmente descrita por estudiosos africanos e outros críticos à política colonial como contrária aos valores da educação assentes essencialmente na formação comum do homem e o seu preparo para coabitar e contribuir numa sociedade democrática. Segundo Walter Rodney (1982), por exemplo, este modelo de educação visou tão somente a "subordinação, exploração, a criação de equívocos

terras e famílias a troco de míseros salários, sujeitos a maus tratos, sem garantia de assistência medica, sujeitos a extorsão pelos comerciantes.

${ }^{12}$ As culturas obrigatórias era a obrigação imposta aos agricultores nativos de produzirem culturas, como o algodão, por exemplo, destinados aos compradores europeus a preços por eles fixados.

${ }^{13} \mathrm{O}$ Estatuto do Indígena como lei discriminatória será discutido no ponto relativo à legislação e filosofia. 
mentais e o desenvolvimento do subdesenvolvimento" (p. 60-61). Essa educação, continua Rodney, não foi concebida para conferir aos nativos a confiança e o orgulho como membros das sociedades africanas, tendo, ao contrário, entre outros vícios, corrompido o pensamento e a sensibilidade dos nativos e impregnando-os com complexos anormais. Al-Mufti (1997), a propósito desses complexos, diz que o africano depois de convertido ao cristianismo, "via na sua própria cultura superstição e arcaísmo, e rejeitava-a em bloco como "não civilizada". [... e] os africanos instruídos fizeram sua a concepção que os europeus tinham da cultura africana tradicional” (p. 226).

Para Brito Neto (2005), as práticas do ensino colonial visaram essencialmente a produção da "ideologia e da subordinação" (p. XI), devido, ainda segundo o autor, à razão de este estar fundado num processo de desnaturalização dos povos nativos pela negação dos seus valores e de sua cultura ancestral.

É também caracterizada, a educação colonial, por Habte e Wagaw (2011), como instrumento de aculturação dos povos africanos. Aculturação que é "o processo educacional de destruição da cultura de um povo e substituí-la por uma nova cultura" (SPRING, 2004, p. 3).

Eduardo Mondlane (1977) pensa a educação colonial como uma cuja finalidade é a submissão e não o desenvolvimento. Eduardo de Sousa Ferreira (1974), por sua vez, acredita que a educação colonial, em função dos seus atos, estava subordinada ao objetivo de produzir mão de obra adestrada sem correr o risco de formar pessoas pensantes e com um pensamento crítico.

Para Boahen (2011), o impacto do sistema educacional colonial foi profundo e tem ressentido nos dias de hoje porque, por um lado gerou um elevado índice de analfabetos em África e, por outro, a elite culta que ele criou acabou por revelar-se, na sua maioria, alienada que reverenciava a cultura e a civilização europeia e menosprezava a cultura e a civilização africana.

Moutinho (2000) considera o processo civilizatório que fundamentou a educação colonial como um logro. Para ele, "a tão pretendida obra da colonização saldava-se em resultados de grande mediocridade. Colonizou-se para se levar a civilização, mas no fim de contas, colonizou-se sem civilizar" (MOUTINHO, 2000, p. 40). As evidências desse 
logro são os $2 \%$ de $\operatorname{assimilados}^{14}$ produzidos pela política colonial até a revogação do estatuto do indígena, o que demonstra na realidade das colônias o investimento na escolarização dos nativos foi um ato tardio devido essencialmente à filosofia de que a utilidade social dos nativos era o trabalho diferenciado ${ }^{15}$ (CASTELO, 2007), e não de cidadãos que deveriam se beneficiar dos privilégios conferidos pelo gozo do direito à educação.

Esses entendimentos sobre a educação colonial levam-nos a inferir que essa educação, como política, esteve longe de efetivar a educação como um direito. Entendemos que a educação como um direito não se circunscreve ao acesso à educação, já em si precário, mas também ao atendimento reservado aos alunos no sistema de ensino e aos ganhos sociais que a mesma proporciona aos seus beneficiários. Por isso, neste capítulo vamos abordar o direito à educação, dando primazia à natureza descritiva da política da educação colonial, focando a abordagem na legislação que a sustentou, as condições de acesso e a natureza da educação oferecida. Apesar de nosso enfoque começar no ano de 1960, faremos, durante as abordagens, referências anteriores a este período, uma vez que os factos, particularmente a legislação citada, apesar de serem anteriores ao referido ano, ampararem a sua realidade educativa.

\subsection{Legislação e filosofia}

Devido à sua supremacia aos demais instrumentos legais da República Portuguesa, recorremos, primeiro, à Constituição Portuguesa de 1933 por essa ser a vigente para o período que o estudo cobre. Nessa constituição, no que ao direito à educação diz respeito, o artigo $8^{\circ}$ enuncia que constituem direitos e garantias individuais dos cidadãos portugueses, entre outros; A liberdade de ensino (ponto 5). Ainda na referida Constituição, declara-se que:

A educação e instrução são obrigatórias e pertencem à família e aos estabelecimentos oficiais ou particulares em cooperação com ele (art. $42 .^{\circ}$ ).

\footnotetext{
${ }^{14}$ Referência legal, na lei do indigenato, do nativo africano instruído e socializado nos padrões europeus.

${ }^{15}$ Refere-se à política discriminatória no trabalho que determinava tarefas específicas, geralmente as melhores remuneradas para os europeus e alguns assimilados, e os socialmente inferiores e pauperrimamente remunerados para os africanos.
} 
O Estado manterá oficialmente escolas primárias, complementares, médias e superiores e institutos de alta cultura (art. 43. ${ }^{\circ}$ ).

O ensino primário elementar é obrigatório, podendo fazer-se no lar doméstico, em escolas particulares ou em oficiais. (Art. $43 .^{\circ} \S 1 .^{\circ}$ ).

O ensino ministrado pelo Estado é independente de qualquer culto religioso, não o devendo porém hostilizar, e visa, além do revigoramento físico e do aperfeiçoamento das faculdades intelectuais, à formação do carácter, do valor profissional e de todas as virtudes cívicas e morais. (Art. $43 .^{\circ} \S 3 .^{\circ}$ ) .

É livre o estabelecimento de escolas particulares paralelas às do Estado, ficando sujeitas à fiscalização deste e podendo ser por ele subsidiadas, ou oficializadas para o efeito de concederem diplomas quando os seus programas e categorias do respectivo pessoal docente não forem inferiores aos dos estabelecimentos oficiais similares. (Art. 44. ${ }^{\circ}$ ).

Contudo, esses postulados constitucionais levantam algumas questões: o que se pretende declarar com o postulado da liberdade de ensino como garantia individual dos direitos do cidadão? Entende-se essa liberdade como o direito dos indivíduos de abrir escolas em conformidade com os requisitos legais, sem distinção, isolados ou em grupos (OLIVEIRA, 1990). Como compreender o carácter obrigatório enunciado? Ao abordar a questão nos termos "cidadãos portugueses", como entender os direitos dos povos nativos de Angola à educação?

Para os povos nativos de Angola, estes postulados, salvo em condições específicas e diferenciadas que serão apresentadas no decorrer do texto, não são sinónimo de garantia do direito à educação. O principal elemento que lhes usurpa este direito é a negação da cidadania portuguesa. Essa negação é declarada em instrumentos como o Acto Colonial, aprovado no Decreto n. 18.570, de 18 de julho de 1930 (PORTUGAL, 1930), e o Decreto-lei n. 39.666, de 2 de junho de 1954 (PORTUGAL, 1954), que promulga o Estatuto dos Indígenas Portugueses das Províncias da Guiné, Angola e Moçambique ${ }^{16}$. Segundo o Estatuto dos Indígenas:

Consideram-se indígenas das referidas províncias indivíduos de raça negra ou seus descendentes que, tendo nascido ou vivendo habitualmente nelas, não possuam ainda a ilustração e os hábitos individuais e sociais pressupostos para a integral aplicação do direito público e privado dos cidadãos portugueses.

\footnotetext{
${ }^{16} \mathrm{O}$ anterior diploma desta natureza é o Estatuto Político, Social e Criminal dos indígenas de Angola e Moçambique de 1926, ambos como colônias de Portugal.
} 
§Único. Consideram-se igualmente indígenas os indivíduos nascidos de pais e mãe indígenas em local estranho àquelas províncias, para onde os pais se tenham temporariamente deslocado. (PORTUGAL, 1954, art. 2. ${ }^{\circ}$ )

Sob essa condição legal de indígenas, os angolanos nativos considerados pelos colonos como povos primitivos, deveriam ser submetidos a um processo que os conduzisse a uma cultura dita "superior". Com essa ideologia, conferia-se, de modo próprio, ao colonizador "a missão de civilizar e incorporar fraternalmente nos organismos político, social e económico da nação portuguesa aqueles a quem se tinha ocupado o território e que eram considerados atrasados, primitivos, crianças grandes" (MOUTINHO, 2000, p. 21). Mas, como Norbert Elias (1990) realça, a noção de civilização e as qualidades a ela insinuadas, "expressa a consciência que o Ocidente tem de si mesmo" (p. 2), dando expressão e legitimando, assim, a "uma tendência continuamente expansionista de grupos colonizadores" (p. 25). Movidos por essa aspiração, "os portugueses cogitaram o processo de assimilação a ocorrer em 3 fases: a destruição das sociedades tradicionais, seguido pelo inculcar da cultura Portuguesa e finalmente a integração do africano "destribalizado" e "portugalizado" na sociedade portuguesa" (BENDER, 1978, p. 219).

Foi essa ideologia civilizatória que fundou a natureza da educação dos povos nativos de Angola. Para o efeito, declarava-se o Estado em promover "por todos meios o melhoramento das condições materiais e moral da vida dos indígenas, o desenvolvimento das suas aptidões e faculdades naturais e, de maneira geral, a sua educação pelo ensino e pelo trabalho para a transformação dos seus usos e costumes primitivos, valorização da sua atividade e integração ativa na comunidade, mediante acesso à cidadania" (PORTUGAL, 1954, art. $4^{\circ}{ }^{\circ}$ ). Nota-se a clara pretensão da promoção de uma educação de conversão dos nativos angolanos em pessoas desprovidas de seus usos, costumes e alienados a sua história.

Para os nativos, foi, então, normatizado o ensino rudimentar. Esse ensino constitui o primeiro grau do ensino indígena. Ele é "exclusivamente reservado às crianças indígenas dos dois sexos, dos 7 aos 15 anos completos, e é ministrado em estabelecimentos denominados escolas de ensino rudimentar" (PORTUGAL, 1950, art. $2 .^{\circ}$ ). Para tal, "o ensino que for especialmente destinado aos indígenas deve visar aos fins 
gerais de educação moral, cívica, intelectual e física, estabelecidos nas leis e também à aquisição de hábitos e aptidões para o trabalho, de harmonia com os sexos, as condições sociais e as conveniências das economias regionais" (PORTUGAL, 1950, art. 6. ${ }^{\circ}$ ). Essa visão de ensino fundava-se no princípio segundo o qual "a contemporização com os usos e costumes indígenas é limitada pela moral, pelos ditames da humanidade e pelos interesses superiores do livre exercício da soberania portuguesa” (PORTUGAL, 1950, art. 3. $\left.{ }^{\circ}, \S 1.\right)$.

Há uma separação e diferenciação da educação escolar formal reservada aos brancos, categorizados como "cidadãos", e da educação reservada aos negros e mestiços, os "indígenas". Senão, o que mais justiçaria numa realidade com leis de discriminação e o histórico do escravismo a criação de duas realidades distintas baseadas fundamentalmente na cor. Essa diferenciação de tratamento, apesar da ideologia difundir as diferenças culturais, ela é essencialmente racista. Porque um branco que é iletrado e que não domine os valores sociais dos europeus, não é necessariamente um indígena, o que revela que "a pele branca era automaticamente a prova de ser "civilizado" e a pele negra a marca de não ser civilizado. Até evidências contrárias, as distinções raciais e culturais coincidiram em 99,3\% dos casos" (HENDERSON, 1992, p. 296). Confirmando as pretensões de alienação dos angolanos, o ensino é exclusivamente ministrado em língua portuguesa.

A língua de instrução foi um dos mecanismos usados para se consumar as premissas da educação como instrumentos de aculturação e que também conferia ao colonizador vantagens no contexto político. Como critério de seleção e de eliminação na educação escolar formal, o domínio da língua europeia, como observam Habte e Wagaw (2001), permitia o acesso ao emprego e ao aprendizado de uma profissão. Acresce-se ainda o facto de "o nível de estudo alcançado no sistema de educação ocidental e o conhecimento de línguas europeias tornarem-se os novos critérios do status social, inseparáveis do nível salarial e do prestigio inerente ao cargo ocupado" (HABTE; WAGAW, 2011, p. 818).

Na realidade escolar na África colonial, e Angola em particular, o domínio da língua portuguesa era uma das principais barreiras para a efetivação da escolarização. Na 
década de 60, verificou-se algum crescimento da população atendida na escola. Porém, a rigidez do sistema, manifesta essencialmente na obrigatoriedade do domínio da língua portuguesa - fala, escrita, leitura e interpretação - eliminava quase todos os alunos inscritos no ensino primário porque "se as provas orais comprovassem que o examinando não fala, nem entende com suficiência, a língua portuguesa, será logo reprovado" (PORTUGAL, 1950, art. 36. ${ }^{\circ}$ § único).

Acreditamos que muito não se esperaria de um ensino numa língua que divorciava os alunos das suas realidades. Uma língua cuja utilidade era essencialmente a interação mecânica durante as horas (até 4 horas/dia) de permanência na escola. Melhor ilustração da língua como obstáculo à escolarização é feita por Mondlane (1977). Ao estudar o aproveitamento dos estudantes negros num liceu em Moçambique, o autor verificou que

[...] os estudantes negros se aproximam dos brancos em ciências físicas e matemática, mas que nas artes, especialmente línguas e literaturas portuguesas, eram mais fracos [...] a pobreza da língua [era] a razão dos seus insucessos noutras matérias de letras, porque, embora os examinadores não soubessem de que raça era o estudante, podiam sempre dizer, pela insuficiência da gramática portuguesa quais eram os alunos africanos (MONDLANE, 1977, p. 69).

Quanto a sua função social, o ensino rudimentar é declarado "essencialmente nacionalista, prático e dirigido à preparação do indígena para poder auferir meios para o seu sustento e da sua família" (PORTUGAL,1950, art. 2. '). Mas, qual é o real significado do aspecto nacionalista e prático desta educação para os angolanos nativos?

O carácter nacionalista, resume-se na exaltação da "portugalidade". Essa "portugalidade" que na óptica de José Pinheiro da Silva, mestiço português nascido em Angola e secretário provincial da educação em Angola (1964-1971), é uma concepção de educação assente no princípio da exigência da mesma língua e, também, no princípio da unidade de ensino. Esse último implica que se eduque um Cuanhama (povos nativos de Angola que habitam o sul e o sudeste de Angola e a região norte da Namíbia) fundamentalmente da mesma maneira que se educa um minhoto (branco português da região do Minho, em Portugal). Para esse antigo diretor de educação "este princípio funda-se tanto nas necessidades de continuidade das tradições, cultura e coesão da pátria, como na ideia de aculturação e assimilação com o objetivo da consecução do 'homem português' para além do étnico" (SILVA, 2009, p. 23). 
Persistindo na defesa do movimento de aculturação dos nativos angolanos, movimento este que para ele é imbuído de "valor, poder e nobreza" (p. 23), Silva (2009) crê que "de nada nos valerá encher as salas de aulas de elementos de todas as etnias, de nada nos servirá desenvolver a economia, se não soubermos formar o entendimento dos que povoam o território, se formos capazes de fazer cada vez mais e melhores portugueses, mediante educação norteada pelos valores perenes da civilização lusíada, como nos tempos de antanho" (p. 23, grifos do autor). Por isso, em defesa dos seus "melhores portugueses" e da sua "civilização", sentencia que

[...] a negritude não pode, de forma nenhuma, constituir princípio de orientação educativa ente nós. Não imaginamos outro quadro de vida em Angola que não seja o nosso. Não podemos adoptar como solução de futuro a concepção panafricanista, contraria as tradições nacionais, ao condicionalismos real da província, por inteiro à margem do nosso pensar e sentir, e inexequível por isso mesmo (SILVA, 2009, p. 24).

Observar que esse pensamento de Silva é manifesto num contexto no qual os movimentos independentistas africanos, inspirados pela negritude e pelo pan-africanismo, já estavam consolidados, em alguns casos já haviam conquistado as independências para os seus países havia 10 anos. Esses movimentos, da negritude e do pan-africanismo, defendiam uma educação universal, de qualidade e relevante com o intuito de promover o bem estar comum, o desenvolvimento socioeconómico e sociedades com igualdade cidadã. Esses valores sobre a educação serão retomados com maior profundidade no capítulo seguinte, que se debruça sobre a educação nas sociedades africanas pós-colonial. Sobre a educação defendida por Silva, a análise dos conteúdos da mesma, a ser feita nos pontos subsequentes deste capítulo, mostra que o ideal da educação era simplesmente o civilizatório, assente no domínio da língua portuguesa (em prejuízo das nativas), nos usos e costumes de Portugal. Por exemplo, as orientações aos professores para o ensino de História no ensino primário, constantes no Boletim Oficial (PORTUGAL, 1964), ditam que o ensino de história na escola destina-se a consolidar o natural sentimento de patriotismo. Sendo assim, continua a referencia ao boletim, é lícito escolher para o objeto de um ensino eminentemente formativo, alguns momentos mais belos e dignificantes da nossa história. As atrocidades cometidas com as guerras de ocupação dos territórios angolanos e, acima de tudo, o tráfico de africanos escravizados não constituíam ementa 
para ilustrar estes dignificantes momentos da história deles. Na instrução de educação social e cívica e moral e religião, deveria levar-se em consideração que:

Temos uma belíssima história para lhes contar, a história de uma nação que descobriu novos mundos ao mundo, espalhando-se por todos os continentes e misturando-se com todas as raças sem quaisquer preconceitos e sem outros intuitos senão os de proteger, de dar as mãos e de caminhar com os seus irmãos em Cristo, arrancando-os do primitivismo do seu viver para a luz da Fé da Civilização (PORTUGAL, 1964).

$\mathrm{Na}$ visão colonial, desde os primórdios da sua presença em África (África Portuguesa no caso), o fim da escola "é difundir entre os indígenas, nos seus povoados selvagens, os mais úteis preceitos de higiene e de moral, ensinar-lhes um oficio e o conhecimento da língua portuguesa" (ÁFRICA PORTUGUESA, 1932, p. 5). E, apesar da tentativa de ajustar a educação ao contexto desenvolvido depois dos já referidos acontecimentos de 1961, os objetivos básicos da política da educação não se alteraram, isto é, continuou "a inculcar os valores Portugueses e a desenvolver nos alunos uma identificação consciente com Portugal para consolidar a unidade nacional" (FERREIRA, 1974 , p. 80).

Dificilmente a educação pensava em desenvolver os povos nativos com uma consciência crítica e com formação técnica que lhes possibilitasse a inserção, em igualdade de circunstâncias com os brancos portugueses, na economia e nos mercados de trabalho em Angola, e talvez de Portugal como um todo.

O carácter prático é, essencialmente, a conformação do ensino a preparação de mão de obra barata para explorar nos seus projetos económicos. Freitas (1964) expõe o pensamento de Norton de Matos, alto Comissário da República para a colônia de Angola entre 1921-1924, sobre a escola primária, uma escola diferenciada da metrópole. Norton de Matos

[...] preconizava que as escolas destinadas à grande massa dos habitantes da província fossem mais oficinas do que escolas, e que nelas, se ensinasse, juntamente, com a língua portuguesa, com a leitura e com a escrita, com as quatro operações e com o sistema de peso e medidas, uma arte ou um oficio, uma profissão manual, o trabalho da terra, da pedra ou dos materiais, conforme as localidades e índole dos habitantes (FREITAS, 1964, p. 12-13). 
É de inferir desse discurso aspirações de se formar uma espécie de proletariado entre os povos nativos que serviriam de mão de obra fácil para os intentos de exploração capitalista. Entendemos, nesse sentido, como propósito da escola colonial a formação de africanos para servirem os níveis mais baixos da administração colonial e servirem as necessidades de mão de obra dos empreendimentos do próprio Estado e das firmas privadas detidas pelos próprios europeus, numa organização social e económica em que, nas palavras de Marcelo Caetano, “os pretos em África devem ser dirigidos e organizados pelos Europeus, mas são auxiliares indispensáveis [...] e devem ser vistos como elementos produtivos organizados ou a ser organizados numa economia dirigida pelos brancos" (DAVIDSON, 1974, p. 11).

Ferreira (1974) considera que esse pensamento é derivado da necessidade de desenvolvimento e industrialização de que Portugal precisava nesse período, motivada pelas mudanças económicas na Europa Ocidental, após a Segunda Guerra Mundial; o desenvolvimento do capitalismo em Portugal per se; as pressões exercidas pelos movimentos independentistas. Em outras palavras, continua Ferreira (1974),

[...] o fracasso de Portugal em industrializar-se tornou-o incapaz de competir com outras potências coloniais. A sua presença em África não era explicada pela necessidade de expandir (como no caso das demais potências coloniais), mas, pelo contrário, pelos resultados da sua economia subdesenvolvida que precisava dos rendimentos coloniais para manter a sua posição (p. 32-33).

E essa necessidade precisava contar com mão de obra local treinada para a demanda, treinamento este incumbido à educação concebida para os nativos.

\subsection{O Acesso}

As condições para o acesso à educação escolar formal estavam definidas na constituição Portuguesa de 1933, para os detentores da cidadania portuguesa, e na Lei do indígena de 1954, para os demais povos nativos de Angola e catalogados pelo regime colonialista como "indígenas", ou seja, não viviam aos costumes e cultura de Portugal e, também, não dominavam a língua portuguesa. Adicionado ao fator legal, o acesso à educação estava, também, condicionado pela disponibilidade de escolas. Sendo que a 
maior parte da população africana vivia nas zonas rurais, as escolas não estavam presentes em todas as circunscrições administrativas.

Uma das limitações do sistema da educação colonial em África e que é ocultada pela estatística é a grande variação de oportunidades entre as diferentes populações na mesma colônia. Em muitas delas, apenas os africanos que viviam próximos das principais cidades tinham oportunidades de frequentar a escola (RODNEY, 1982, p. 64).

Em Angola, essa era também a realidade. As escolas estavam localizadas principalmente nas cidades ou em localidades de grande concentração de habitantes brancos. Num inquérito realizado em zonas rurais de Angola, em 1971 (4 anos antes da independência), revelou que no universo dos "2.643 inquéritos aplicados evidenciaram que 48,5 por cento dos filhos dos camponeses não frequentaram a escola em 1969/70 porque não existiam prédios escolares disponíveis” (FERREIRA, 1974, p.87).

Todavia, o maior fator inibidor do acesso à educação era, realmente, a questão da cidadania. Os nativos na condição de indígena não tinham acesso às escolas do ensino primário sob a tutela do Estado. As escolas a eles reservada eram as do ensino preparatório para as escolas primárias. Mas, "os alunos africanos não tinham acesso às escolas públicas ao menos que fossem detentores do estatuto de africano 'assimilado'. E a cidadania não era adquirida pela frequência das escolas, mas através de um longo processo administrativo" (FERREIRA, 1974, p. 71). O que essa condição representava nos índices de exclusão escolar? Julgamos que os dados sobre a população, discriminados pela cor e estatuto de assimilado ou não, podem ilustrar, apenas como indicador, a população atendida na escola pública como resultado de uma política essencialmente de exclusão dos povos nativos (Tabela 1).

Apercebe-se nesses números que a maioria da população era constituída por angolanos nativos, designados na tabela por "pretos". E salientamos que depois de 1950 há um crescimento considerável da população branca em Angola devido ao apelo e ao incentivo de Salazar aos portugueses para que se instalassem nas províncias em África em razão da crise económica em Portugal. As províncias africanas, Angola em particular, ofereciam condições para que esses portugueses pudessem prosperar no comércio, na 
agricultura e na indústria. Do número total de angolanos "pretos", somente 23.886 eram considerados "civilizados" em 1940, e 30.089, em 1950 (Tabela 2).

Tabela 1: População de Angola segundo os censos de 1940, 1950 e 1960

\begin{tabular}{|l|c|c|c|}
\cline { 2 - 4 } \multicolumn{1}{c|}{} & $\mathbf{1 9 4 0}$ & $\mathbf{1 9 5 0}$ & $\mathbf{1 9 6 0}$ \\
\hline Brancos & 44.083 & 78.826 & 172.529 \\
\hline Mestiços & 28.035 & 29.648 & 53.392 \\
\hline Pretos & 3.665 .829 & 4.036 .687 & 4.604 .362 \\
\hline Total & $\mathbf{3 . 7 3 8 . 0 1 0}$ & $\mathbf{4 . 1 4 5 . 2 6 6}$ & $\mathbf{4 . 8 3 0 . 4 4 9}$ \\
\hline
\end{tabular}

Fonte: Censos de 1940, 1950 e 1960 (PORTUGAL, 1943a, 1943b, 1955a, $1955 b, 1955 c, 1969 b$ e $1969 c)$

A população não civilizada representa justamente aqueles a quem o acesso ao ensino não era garantido nas escolas públicas. O número de analfabetos neste grupo, como mostra o censo de 1950, é 3.976.267, contra os 33.644 que sabiam ler e escrever. Porém, mesmo entre os civilizados, o número de analfabetos, particularmente crianças entre os 5-14 anos, apresentavam índices elevados, o que tende a demonstrar uma política de educação que não salvaguardava o direito à educação. Apresentamos a seguir os índices da população civilizada, segundo a instrução, tendo como referência o censo de 1950.

Tabela 2: População não civilizada ${ }^{17}$

\begin{tabular}{|l|c|c|}
\cline { 2 - 3 } \multicolumn{1}{c|}{} & $\mathbf{1 9 4 0}$ & $\mathbf{1 9 5 0}$ \\
\hline Pretos & ------ & 4.001 .217 \\
\hline Mestiços & ------ & 3.313 \\
\hline Total & $\mathbf{3 . 6 4 6 . 3 9 9}$ & $\mathbf{4 . 0 0 4 . 5 3 0}$ \\
\hline
\end{tabular}

Fonte: Censos de 1940 e 1950 (PORTUGAL, 1943a, $1943 b, 1955 a, 1955 b$ e 1955c)

\footnotetext{
${ }^{17}$ Não estão refletidos os dados de 1960 porque a quando da publicação dos resultados do censo deste ano, 1969, já não vigorava formalmente o estatuto de indígena. A população angolana, depois disso, era na sua totalidade tida como portuguesa.
} 
Tabela 3: População civilizada segundo a instrução em Angola

\begin{tabular}{|l|c|c|c|c|c|}
\cline { 2 - 6 } \multicolumn{1}{c|}{} & Primário & Secundário & Analfabeto & Total $^{\text {I8 }}$ & Total geral $^{\text {19 }}$ \\
\hline Homens & 24.827 & 7.783 & 18.845 & $\mathbf{5 6 . 6 3 1}$ & $\mathbf{7 5 . 4 7 6}$ \\
\hline Mulheres & 14.892 & 3.388 & 24.722 & $\mathbf{3 1 . 1 5 7}$ & $\mathbf{5 9 . 8 7 9}$ \\
\hline Total & $\mathbf{3 9 . 7 1 9}$ & $\mathbf{1 1 . 1 7 1}$ & $\mathbf{4 3 . 5 6 7}$ & $\mathbf{9 1 . 7 8 8}$ & $\mathbf{1 3 5 . 3 5 5}$ \\
\hline
\end{tabular}

Fonte: Censo de 1950 (PORTUGAL, 1955a, 1955b e 1955c)

Dos 43.567 analfabetos entre a população civilizada, 18.153 eram brancos e 25.414 eram mestiços. Quanto à população branca analfabeta, gostaríamos de ter a destrinça entre os brancos naturais de Angola e os provenientes da metrópole. Um elevado número de analfabeto entre os brancos naturais de Angola iluminaria a nossa tese, advogando que a discriminação e a negação do direito à educação, apesar de ser mais evidente na população negra nativa, ela era também resultado de uma política de educação do governo português que, na generalidade, não privilegiava a efetivação do direito à educação nas escolas coloniais. Essa negação pode ficar mais evidente com os dados, no quadro que se segue, que apresentam os índices de escolarização entre as crianças em idade escolar, por norma, coberta pela escolarização obrigatória.

Tabela 4: Idades de 5-9 anos

\begin{tabular}{|c|c|c|c|c|c|}
\cline { 2 - 6 } \multicolumn{1}{c|}{} & Primário & Secundário & Analfabeto & Total $^{\mathbf{2 0}}$ & Total geral $^{\mathbf{2 1}}$ \\
\hline Homens & 47 & Xxxx & 4.376 & $\mathbf{3 . 0 9 7}$ & $\mathbf{7 . 4 7 3}$ \\
\hline Mulheres & 65 & Xxxx & 4.313 & $\mathbf{2 . 9 1 5}$ & $\mathbf{7 . 2 2 8}$ \\
\hline Total & $\mathbf{1 1 2}$ & $\mathbf{X x x x}$ & $\mathbf{8 . 6 8 9}$ & $\mathbf{6 . 0 1 2}$ & $\mathbf{1 4 . 7 0 1}$ \\
\hline
\end{tabular}

Fonte: Censo de 1950 (PORTUGAL, 1955a, 1955b e 1955c)

Nessa faixa etária, o total da população de crianças "brancas" é de 7.596. Dessas, 69 frequentavam a escola primária e 3.968 são estimadas como analfabetas. Para as crianças "pretas" a população estimada é de 3.702. Sendo que 2.586 são analfabetas e 19

\footnotetext{
${ }^{18}$ Total da população na escola.

${ }^{19}$ População geral

20 Total da população deste grupo na escola

21 Total da população nestas idades
} 
delas frequentam a escola primária. Uma das razões que encontramos para a elevada disparidade entre a população de crianças, particularmente as "brancas" e os que frequentam a escola, é a entrada tardia na escola, que em muitos casos acontece apenas aos 7 anos de idade.

Tabela 5: Idades de $10-14$ anos

\begin{tabular}{|l|c|c|c|c|c|}
\cline { 2 - 6 } \multicolumn{1}{c|}{} & Primário & Secundário & Analfabeto & Total $^{\mathbf{2 2}}$ & Total geral $^{\mathbf{2 3}}$ \\
\hline Homens & 787 & 51 & 1.103 & 5.855 & 6.958 \\
\hline Mulheres & 880 & 54 & 1.509 & 5.238 & 6.747 \\
\hline Total & $\mathbf{1 . 6 6 7}$ & $\mathbf{1 0 5}$ & $\mathbf{2 . 6 1 2}$ & $\mathbf{1 1 . 0 9 3}$ & $\mathbf{1 3 . 7 0 5}$ \\
\hline
\end{tabular}

Fonte: Censo de 1950 (PORTUGAL, 1955a, 1955b e 1955c)

Nesse grupo, encontramos apenas 339 crianças brancas analfabetas, num universo de 6.422. Mas, a concentração das escolarizadas no ensino primário, a razão de 1.033 contra os 82 no secundário, pode dar indicadores sobre os índices de reprovação dos quais a escola colonial produzia. Para as crianças "pretas" temos a relação de 1.623 analfabetos, e 248 a frequentarem o ensino primário e 4 no secundário.

Esses números mostram que estando a maior parte da população entre os não "civilizados" e, mesmo, entre os "civilizados" ("pretos", "brancos", e "mestiços" no seu todo) a oferta da educação esteve muito aquém de atender a totalidade da população abrangida na escolaridade obrigatória, que era dos 7 aos 12 anos, em 1960, passando para dos 6-12 anos, em 1964. Essa prática de exclusão se manteve ao longo da presença colonial em Angola. Mesmo depois da abolição formal do estatuto de indígena para a população nativa, a escola não se democratizou para satisfazer as necessidades de educação dos angolanos, num momento em que Portugal já era membro das Nações Unidas, o que pressupunha o respeito dos instrumentos sobre direitos humanos adoptados pelos países membros dessa organização. Esse fraco atendimento está resumido no quadro que abaixo apresentamos.

\footnotetext{
${ }^{22}$ Ver nota 20.

${ }^{23}$ Ver nota 21.
} 
Tabela 6: Alunos matriculados no ensino primário

\begin{tabular}{|c|c|c|c|}
\hline \multirow{2}{*}{ Período } & \multicolumn{2}{|c|}{ Modalidade de ensino } & \multirow{2}{*}{ Total } \\
\cline { 2 - 3 } & Oficial & Particular & \\
\hline $1956-57$ & 49.044 & 20.170 & 69.214 \\
\hline $1957-58$ & 60.795 & 22.265 & 83.060 \\
\hline $1958-59$ & 58.637 & 27.139 & 85.776 \\
\hline $1959-60$ & 71.898 & 32.129 & 104.027 \\
\hline $1960-61$ & 71.906 & 33.875 & 105.781 \\
\hline $1961-62$ & 77.596 & 34.730 & 112.326 \\
\hline $1962-63$ & 85.061 & 38.580 & 123.641 \\
\hline $1963-64$ & 111.207 & 41.881 & 153.088 \\
\hline $1964-65$ & 157.719 & 45.658 & 203.377 \\
\hline $1965-66$ & 178.915 & 43.411 & 222.326 \\
\hline $1966-67$ & 219.728 & 48.040 & 267.768 \\
\hline $1967-68$ & 49.101 & 52.998 & 302.099 \\
\hline $1968-69$ & 244.784 & 51.485 & 296.269 \\
\hline $1969-70$ & 344.814 & 47.995 & 392.809 \\
\hline $1970-71$ & 389.828 & 51.157 & 440.985 \\
\hline $1971-72$ & 443.183 & 51.617 & 494.800 \\
\hline $1972-73$ & 466.213 & 46.729 & 512.942 \\
\hline
\end{tabular}

Fontes: Anuários estatísticos 1967, 1968 e 1974 (ANGOLA, 1968, 1969a e 1974)

Os dados não nos permitem discriminar os alunos que frequentavam o ensino primário e ou o ensino rudimentar. Sabemos que a não destrinça, intencional, das autoridades, nessa perspectiva, dificulta a análise média real de atendimento da população nativa. Por outro lado, a média de crescimento de dezenas de milhares de alunos entre os anos letivos, pode ser o natural reflexo do crescimento da população branca fomentado pelo programa de povoamento do território angolano com população de origem europeia no período entre 1950 e 1974. É essa população branca que para além do ensino público tinha recursos para frequentar as escolas particulares. Acrescemos também o facto de se permitir o acesso ao ensino primário da maioria dos nativos depois do levantamento político de 1961.

Ao negar a escola primária para os nativos de Angola, o governo português regulamentou o ensino rudimentar (chamado de ensino de adaptação depois de 1956) para atender aos nativos. Como era esse ensino organizado? Propusemo-nos, então, a 
compreender a organização desse segmento de ensino, e também os fins que ele se propunha alcançar.

\section{Estrutura do ensino rudimentar}

Como definido no regulamento do ensino rudimentar e do magistério rudimentar de 1950, o ensino rudimentar compreendia uma classe preparatória e mais três classes ascendentes, correspondendo cada uma delas a um ano escolar, o que perfaz, 4 anos escolares. Os limites de idade para a frequência desses níveis estava assim distribuído: classe preparatória (7-9 anos), primeira classe (8-11 anos), segunda classe (9-12 anos) e terceira classe (10-14 anos).

A classe preparatória visava a aquisição de vocabulário de uso corrente e a iniciação nos hábitos escolares e no trabalho compatível com a idade e o sexo dos alunos. Poderiam, também, iniciar-se nessa classe o ensino da leitura, da escrita e do cálculo, desde que os alunos mostrassem domínio da língua portuguesa e desenvolvimento mental.

As restantes três classes destinavam-se a habilitar os alunos no domínio da língua portuguesa (falar, ler e escrever) e o cálculo em português ${ }^{24}$. Essas classes estavam também destinadas a preparar trabalhadores rurais. Começa-se, a partir dessas classes, a formar a mão de obra que daria sustento a empreitada colonial nos domínios da agricultura, agropecuária e outros ofícios. As atividades das classes desenvolviam-se, em cada dia útil, com a seguinte carga horária: duas horas, pelo menos, de trabalho de campo, agrícolas ou agropecuários; três horas de atividades escolares; duas, pelo menos, de práticas oficinais, nas escolas onde não houver possibilidades de se efetuarem os trabalhos de campo.

Como currículo, o ensino rudimentar era essencialmente constituído pelas mesmas disciplinas em todos os anos de escolarização. Essas disciplinas estavam, efetivamente,

\footnotetext{
${ }^{24} \mathrm{O}$ processo da operacionalização do cálculo nas línguas bantu é diferente do da língua Portuguesa em muitos aspectos. Por exemplo, há números que ditos nas línguas bantu são o equivalente a uma operação de adição. Então um exercício de soma que pode fazer sentido na língua Portuguesa, pode não fazer sentido numa determinada língua bantu. Para mais detalhes desta discussão, ver Chimbutane e Strout (2001). Educação bilíngue em Moçambique: Refletindo criticamente sobre políticas e práticas.
} 
concebidas para que o ensino cumprisse os propósitos da política colonial sobre a educação dos nativos.

O currículo mostra um ensino orientado para a formação de mão de obra e a promoção da "portugalidade" pela língua, pela religião e pela moral. $\mathrm{O}$ artigo $44 .^{\circ}$ do regulamento recomenda que "os livros e compêndios a usar nas escolas de ensino rudimentar não poderão conter nada em desmerecimento da nação e da civilização portuguesa, da sua história e ação colonizadora, do seu governo e as autoridades, da Igreja Católica e sua atuação missionária”.

$\mathrm{Na}$ disciplina de canto coral, os alunos deveriam aprender o hino de Portugal e canções populares portuguesas. As canções locais, apesar de autorizadas, eram consideradas como folclore indígena, uma mostra da arrogância cultural do colonizador. A introdução de canções do "folclore indígena" não pode ser vista como a valorização da cultura local porque a necessidade de tradução das referidas canções para que constassem do currículo e cumprissem com a exigência do uso do português como língua única na escola, desvirtuava a essência das referidas canções. As canções nas tradições nativas incorporavam vários significados sociais por estarem relacionadas a rituais e a vários processos culturais.

As atividades agrícola e agropecuária, obedecendo a condições e conveniências das economias regionais, deveriam ser de carácter prático. Nas atividades oficinais, buscava-se o aprendizado de artes e ofícios que se praticavam nas oficinas das missões, estando os alunos integrados nas práticas e no ritmo de trabalho normal das mesmas oficinas.

Como ilustração das diferenças entre o conteúdo do ensino destinado aos nativos em relação aos conteúdos do ensino destinado aos brancos portugueses, apresentamos os Quadros 3 e 4 sobre as duas realidades.

Percebemos uma política de educação, como caracterizada por Cruz (2006), cujo empenho foi, sobretudo, "um meio através do qual os indígenas ascendessem à civilização: educar, instruir o indígena, era o objetivo e ultimo da colonização e consistiu no seguinte: na necessidade de instruir o indígena que a educação se faz pelo trabalho e para o trabalho" (p. 213). 
Quadro 3: Conteúdos do ensino rudimentar

\begin{tabular}{|l|l|}
\hline \multicolumn{1}{|c|}{ Disciplina } & \multicolumn{1}{c|}{ Classes } \\
\hline Português & $1,2,3$ \\
\hline Aritmética & $1,2,3$ \\
\hline Desenho e trabalho manual & $1,2,3$ \\
\hline Religião e moral & $1,2,3$ \\
\hline Canto Coral & $1,2,3$ \\
\hline Educação física & $1,2,3$ \\
\hline $\begin{array}{l}\text { Atividades agrícola } \\
\text { agropecuária }\end{array}$ & $1,2,3$ \\
\hline Atividades oficinais & $1,2,3$ \\
\hline \multicolumn{2}{|c|}{} \\
\hline
\end{tabular}

Quadro 4: Conteúdos do ensino primário

\begin{tabular}{|l|l|}
\hline \multicolumn{1}{|c|}{ Disciplinas } & \multicolumn{1}{c|}{ Classes } \\
\hline Língua Portuguesa $^{25}$ & $1,2,3,4$ \\
\hline Geometria & 3,4 \\
\hline História da Pátria & 3,4 \\
\hline Ciências Geográficas Naturais & $1,2,3,4$ \\
\hline Moral e religiãa ${ }^{26}$ & $1,2,3,4$ \\
\hline Desenho & $1,2,3,4$ \\
\hline Trabalho Manual & $1,2,3,4$ \\
\hline Educação Física & \\
\hline Educação Musical & $1,2,3,4$ \\
\hline
\end{tabular}

Fonte: Portugal, 1964

\subsection{Os professores no sistema de ensino colonial}

Antes de 1961, os professores eram essencialmente catequistas. Esses professores tinham em regra em nível de formação de até dois anos para os católicos e de 4 anos para os protestantes. O objetivo do ensino ministrado "nestas escolas de formação de professores" eram apenas a leitura e a escrita. Após a criação das escolas rudimentares, os alunos eram preparados nessas escolas numa formação de até 4 anos e depois aproveitados para o magistério. Concluído esse período, os mesmos eram habilitados para o ensino até a 4 classe nessas mesmas escolas. Depois das reformas de 1962/63, houve a definição de três categorias de professores, nomeadamente: professor de posto, professor monitor, e professor primário.

- Professor de posto - a idade de admissão para esses cursos era a de 14 anos. A formação durava 4 anos. A escolaridade mínima de admissão era o 3 ano do ensino primário. O currículo era constituído pelas disciplinas de língua

\footnotetext{
${ }^{25}$ Designada de "Língua Nacional" depois da reforma de 1964.

${ }^{26}$ Designada de "Instrução de educação social e cívica e moral e religião" depois da reforma de 1964.
} 
portuguesa, história de Portugal, a "portugalidade", geografia, aritmética, desenho e trabalho manual, religião, moral, agricultura, pedagogia e pluricultura. Os seus postos de trabalho eram nas missões religiosas.

- Professores "monitores" - o monitor era um adulto a partir dos 18 anos e com a escolaridade de 4 anos. Para a sua formação destinada ao exercício do magistério, o mesmo era submetido a dois cursos intensivos (com dois meses de duração) e periódicos. As disciplinas do currículo era a língua portuguesa, a aritmética, a geografia, a "portugalidade" e a pedagogia. O objetivo do curso consistia em prepará-los para o ensino nos 4 anos do ensino primário.

- Professores Primários - esses eram formados nas escolas denominadas de "Magistério Primário", que eram instituições especializadas na formação de professores. Esses professores eram formados para atenderem a escolarização dos filhos dos colonos e os da "burguesia" local. O currículo era composto por várias disciplinas, entre as quais destacamos as seguintes: língua portuguesa, psicologia, pedagogia, aritmética e música.

Os magistérios primários em Angola foram criados para, entre outros fatores, a necessidade de formar indivíduos para sustentar a política colonial, a projeção ao mundo da imagem do desenvolvimento do sistema de educação, a necessidade do atendimento local dos filhos dos colonos e a dificuldade de se fornecer professores suficientes a partir de Portugal.

\subsection{Outros atores}

Para além do estado português, que para o caso da educação dos povos nativos, praticamente, reservou o seu papel às questões de regulamentação, a educação dos nativos em Angola sempre contou, desde as viagens de Diogo Cão até ao período do constitucionalismo, com a participação das missões religiosas, particularmente as católicas e as protestantes. Essas missões religiosas tiveram em mãos quase a totalidade da educação dos africanos, embora, em função das relações que cada confissão religiosa 
tinha com o Estado, o trabalho de cada uma delas teve disseminação e valorização diferenciadas.

As missões, tanto as católicas como as protestantes, tinham como base primária do seu trabalho a evangelização e a conversão dos africanos ao cristianismo. A adopção das línguas locais, intercaladas com o português ou o inglês, resultava não da valorização que emprestavam a língua, mas a necessidade de acelerar o processo de conversão dos africanos ao seu evangelho.

Por outro lado, o uso das línguas locais e, no caso das missões protestantes, o uso da língua inglesa, limitava a mobilidade dos nativos no sistema de educação, uma vez que as missões encarregavam-se essencialmente do ensino primário. O não domínio da língua portuguesa era o natural obstáculo a não frequência dos níveis posteriores do sistema de educação, bem como a não aquisição da cidadania portuguesa. Porque para as autoridades colônias, o não domínio da fala, leitura e escrita em português, por um nativo, era sinónimo de analfabetismo, logo, não civilização.

Entretanto, o trabalho das missões católicas, devido a sua relação privilegiada com o estado português, acabou por se identificar como um ator relevante na implementação da política de educação do Estado colonial em Angola. Ademais, em razão das animosidades entre Portugal e as missões protestantes, tidas por Portugal como estrangeiras, as ações destas últimas acabaram por ser marginalizadas na política de educação do Estado. Ressalvamos que essa marginalização oficial do trabalho das missões protestantes não desvaloriza o trabalho por elas desenvolvido na educação dos nativos angolanos. O exemplo mais saliente, que já é de uso corrente, é o facto de os líderes dos movimentos de libertação, tidos como pais fundadores da República de Angola por terem rubricado com Portugal os acordos da independência de Angola, nomeadamente, Holden Roberto, da Frente Nacional para a Libertação de Angola (FNLA), Agostinho Neto, Movimento Popular de Libertação de Angola (MPLA), e Jonas Savimbi, União Nacional da Independência Total de Angola (Unita) terem sido educados nas escolas das missões protestantes. A eles juntam-se outros angolanos que assumiriam os destinos do país independente. 
As missões católicas foram os parceiros escolhidos pelo Estado português para a sua política de educação dos nativos. Em 1941, aprovou-se o Decreto-lei n. 30.207 intitulado de "Estatuto Missionário" (PORTUGAL, 1941). Este decreto determinou que o ensino especialmente destinado aos indígenas deveria ser inteiramente confiado ao pessoal missionário e a seus auxiliares, o que consumou a separação da educação entre os nativos e dos europeus. Essa educação nas missões católicas tornou-se a única possibilidade para a maioria dos nativos de serem instruídos sob a responsabilidade do Estado português, cuja participação era, sobretudo, a autorização legal para a abertura de escolas. A educação nas missões católicas assentava-se fundamentalmente no ensino da língua e da cultura portuguesa para responder à exigência do Estado e, também, no ensino da religião cristã sob o prisma da Igreja Católica.

Para além de ter sob sua responsabilidade o ensino rudimentar para os nativos, as missões católicas tinham também sob sua responsabilidade a formação de professores para servirem o ensino rudimentar, o magistério rudimentar. Os alunos dos magistérios rudimentares eram nativos "indígenas" de um ou outro sexo que tenham feito o ensino rudimentar eles próprios. Nessas escolas, os futuros professores frequentavam um programa de formação com a duração de quatro anos e com conteúdos assentes, essencialmente, em desenvolvimento comunitário, pedagogia e noções do programa de estudo do ensino secundário.

Para o direito à educação dos nativos, as missões católicas não representaram uma visão diferenciada relativa à salvaguarda deste direito. Em primeiro lugar, a igreja tinha a sua ambição, manifesta desde os primeiros contatos, de evangelização e a conversão para a doutrina católica dos povos nativos. Por isso, as escolas para eles eram a melhor oportunidade de consumarem essa pretensão. Por isso, os programas das missões católicas eram assentes no catolicismo. Por outro lado, a igreja comungava com o discurso civilizatório das autoridades coloniais, podendo inferir-se um discurso semelhante sobre a realidade histórica e cultural dos povos nativos de Angola.

Em suma, retomamos o princípio de que a educação como direito é o fundamento da política da educação que aspira ao empoderamento de cidadãos de uma determinada realidade. A satisfação desse direito conduz ao desenvolvimento de sujeitos que, de modo 
crítico, buscam o bem comum para as suas sociedades. Mas num contexto não democrático, como o da colonização, as relações sociais são essencialmente de exploração de uma maioria por uma minoria. Criam-se mecanismos formais e informais para sustentar os ditames da exploração da população e consequente privação dos seus direitos. A negação da educação é um dos principais instrumentos para o efeito, devido, sobretudo, à sua natureza de propulsor de outros direitos. Como Spring (2004) exemplifica, a negação do direito assenta no tratamento desigual manifesto nos prédios escolares disponibilizados aos diferentes grupos, os manuais e o currículo concebido. Para os estudantes que não dominam a língua de instrução são efetivamente excluídos de uma educação com algum significado.

Nas realidades das colônias, os colonizadores trouxeram o seu sentimento de superioridade racial e cultural sustentados pelas civilizações dos seus povos e pelas religiões que os acompanhavam - a católica e a protestante. Criaram leis desiguais para formalizar este pensamento e com ele concretizar a negação dos direitos humanos fundamentais, entre eles o direito à educação. Pela diferenciação dos curricula, dos professores, das condições para o ato pedagógico, pelo não reconhecimento das particularidades culturais a atender no processo educativo, pela não valorização da língua dos povos e do não reconhecimento do valor da educação para o desenvolvimento do indivíduo e da sua comunidade, afere-se que educação desse período não se ajustava aos princípios definidos pelos vários instrumentos internacionais sobre a educação como direito humano. 


\section{O DIREITO À EDUCAÇÃO NA POLÍTICA EDUCACIONAL NA PRIMEIRA REPÚBLICA (1975-1991)}

Em 11 de novembro de 1975 proclama-se a independência de Angola. Essa independência seria o culminar da luta de libertação contra a dominação colonial, mas não significaria o fim da exclusão por opções políticas, nem o término da guerra. $\mathrm{O}$ processo de luta pela independência de Angola foi feito por três movimentos distintos, nomeadamente, a FNLA, o MPLA e a UNITA.

Devido ao golpe de Estado de 1974 em Portugal, acelerou-se o processo para

independência de Angola e também de outras colônias portuguesas em África. Para o efeito, foram assinados os Acordos de Alvor entre o governo português e os movimentos de libertação de Angola. Nesses acordos, o Estado português reconhecia esses 3 movimentos como "únicos e legítimos representantes do povo angolano". Reconhecia também o direito do povo angolano à independência. Para atender ao período de transição para a independência, constitui-se um governo de transição cujo colégio presidencial era composto por um representante de cada movimento de libertação. Mas, apesar dos princípios definidos nos Acordos de Alvor, não houve entendimento entre os três movimentos, o que resulta depois numa guerra civil que se prolonga até 2002. O MPLA proclamou a independência em Luanda, constituiu e consolidou a República Popular de Angola (RPA). Agostinho Neto foi indicado pelo MPLA como presidente da República nesse mesmo dia, contudo governou apenas até 10 de setembro de 1979 por razão de sua morte por doença em Moscovo, URSS. Em 21 de setembro, José Eduardo dos Santos toma posse como presidente da República por indicação do bureau político do MPLA, governando o país até o presente.

Com a proclamação da independência, o país passa a designar-se por República Popular de Angola. Aprova-se a primeira Lei Constitucional da RPA de 11 de novembro de 1975 (CORREIA e SOUSA, 1996). No espírito dessa Lei, entre os seus princípios, a RPA é declarada como Estado soberano, independente e democrático e, também, como Estado laico. Ao MPLA, à luz dessa lei, é-lhe conferido o estatuto de legítimo representante da República e cabia a ele a direção política, econômica e social da nação. 
Como orientação política e de governo, a Lei Constitucional define que a RPA funda-se nas seguintes orientações: a) um sistema de direção econômica centralizada e planificada, b) a edificação de uma sociedade socialista, c) um sistema político de partido único. Esta orientação vai definir as origens das políticas públicas dessa República. Nela, "os objetivos fundamentais no domínio econômico e social e a correspondente definição e aplicação da sua política econômica tiveram sempre origem nas conclusões e orientações decididas nos Congressos do Movimento Popular de Libertação de Angola (FERREIRA, 1999, p. 14). Cabia a esse partido, ainda segundo Ferreira (1999), “constitucionalmente, o papel de definição e orientação do Estado e do Governo e sendo o Congresso o seu órgão supremo, foi às recomendações daí- de horizonte temporal anual, trienal ou quinquenal - que a vida econômica e política angolana sempre se subordinou" (p.14). Para o autor que vimos citando, e que tomamos os exemplos sobre a origem dos conteúdos da política, as características do Estado e do governo sobre o papel orientador era enfatizado "nomeadamente quando era referido que as orientações para o desenvolvimento econômico e social do País traçados pelo Congresso do Partido ${ }^{27}$ para cada período constituem a base de elaboração do Plano Nacional passando, assim, a ter força de lei. A sua contrapartida encontrou correspondência legislativa: "(O Plano Nacional) consiste no conjunto de disposições e diretivas que orientam a ação do Governo [...] e poderá ser estabelecido para períodos de um ou vários anos e será elaborado com base nas orientações para o desenvolvimento econômico e social aprovados pelo Congresso do MPLA/PT” (FERREIRA, 1999, p.15, grifos do autor).

O Conselho da Revolução (ver Anexo I), como o órgão supremo do poder do Estado, detinha as principais responsabilidades sobre questões econômicas, políticas e sociais, em detrimento do governo. Esse conselho era presidido pelo presidente da

\footnotetext{
${ }^{27}$ O congresso é o órgão supremo do MPLA que determina o caráter e a orientação ideológica do Partido, ao qual incumbe apreciar e definir as linhas gerais da política nacional e internacional, que orientam a ação e a atividade das estruturas e dos militantes do Partido, bem como das organizações sociais e associadas (Disponível em:〈www.mpla.ao〉. Acesso em: 14 maio 2014). Quanto aos membros participantes do congresso, apresentamos como ilustração, a composição do sexto congresso do MPLA. Participaram o Presidente do Partido, os membros do comitê central, no gozo dos seus direitos; os deputados do grupo parlamentar, membros do executivo (como partido no poder), representantes da OMA (organização feminina), representantes da MPLA (organização juvenil). Participaram ainda os antigos combatentes filiados ao partido, representantes de organizações associadas ao MPLA, delegados de comunidades no estrangeiro.
} 
República. Quanto à sua composição, esta era dominada pelos representantes do sector militar e do MPLA, em contrapartida a representação do governo.

Em 1997, foram aprovadas novas alterações da Lei Constitucional. De acordo com Ferreira (1999), as alterações fundamentais ao texto anterior foram:

1. O desenvolvimento econômico e social assente na propriedade socialista;

2. Um sistema de direção econômica centralizada e planificada;

3. A construção de uma sociedade socialista;

4. A transformação do MPLA em partido marxista-leninista (MPLA/PT) com o seu correspondente papel dirigente do Estado angolano.

Na estrutura da direção do governo, o presidente da República tornou-se o chefe do governo que preside o Conselho de Ministros. Anterior a essa alteração, o governo era dirigido pelo Primeiro Ministro sob orientação do Conselho da Revolução e Presidente da República.

A organização política administrativa do Estado durante a vigência do regime de partido único de orientação socialista em Angola caracteriza-se pela organização vertical, hierarquizada, com um poder centralizador. Nesse regime, "os órgãos do Estado organizam-se e funcionam de acordo com os princípios da unidade de poder e do centralismo democrático" (Lei Constitucional de 1980, artigo 31 (CORREIA e SOUSA, 1996)). Inspirado no modelo organizacional desenvolvido na Rússia bolchevique, o centralismo democrático na sua essência advoga a democracia, como princípio, na discussão de ideias para a garantia da liberdade dos indivíduos, e o princípio do centralismo, na execução da ação para a eficácia pretendida na efectivação das ideias. Idealizando uma organização de massas, os normativos criados para legitimar a ação de um órgão de governo fundado nas massas eram supostos desenvolver as fundações para que as ações do governo fossem resultado de decisões da maioria representada nos vários órgãos e níveis do governo. Na sua declaração, conforme Correia e Sousa (1996), o centralismo democrático evocado na lei caracterizava-se pelas seguintes formas:

a) Cada órgão desenvolve, nos limites das suas competências, a iniciativa no sentido da participação das organizações de massas na sua actividade e do aproveitamento dos recursos locais; 
b) As determinações dos órgãos superiores são de cumprimento obrigatório para os inferiores;

c) Os órgãos inferiores respondem pela sua atividade perante os superiores;

d) Em todos os órgãos colegiais vigora a liberdade de discussão, o exercício da crítica e da autocrítica e a subordinação da minoria à maioria;

e) A actividade dos órgãos executivos e administrativos locais obedece aos sistemas da dupla subordinação aos órgãos executivo e administrativo do escalão imediatamente superior e ao órgão do poder popular do respectivo escalão.

Essa declarada forma de organização do Estado e da sua administração resultou, contudo, num modelo de Estado e de administração burocrática privilegiando a hierarquia e a centralização. Nesse contexto político, no qual "as determinações dos órgãos superiores são de carácter obrigatório", os cidadãos individualmente ou colectivamente estavam arredados da participação na tomada de decisão ou na indução dos conteúdos da pública. Por isso, de modo instrumental, as organizações de massa deveriam, na concepção do Partido, "incentivar a participação política, disseminar e explicar as políticas partidárias e auxiliar na sua implementação. Os riscos eram [...] de que as organizações de massa poderiam tornar-se instrumentos para o controlo do Partido sobre as massas ao invés de veículos para na tomada de decisão" (SOMMERVILLE, 1986, p.117). Outro factor que também reforçou a ideia de concentração de poder é demonstrado por Hodges (2002):

\footnotetext{
Embora, em termos formais, a constituição pós-independência estabelecesse a primazia do partido e, desse modo, também o papel decisor nuclear dos seus órgãos dirigentes [o comité central e o bureau político], o sistema político pósindependência revelou, desde o inicio, uma forte tendência para o presidencialismo. Na vigência da constituição, o chefe do Estado combinava três poderosas funções; era presidente do partido, presidente da República e comandante supremo das forças armada. (p.79).
}

À medida que a guerra civil se foi intensificando, e alegando-se imperativos da segurança de Estado, o círculo de decisão foi se comprimindo ao redor do presidente, o que adiou o desenvolvimento de um sistema mais pluralista e participativo de governação. 
Relativo à formação de quadros - que se relaciona ao projeto educativo -, em 1977 evocou-se esta tarefa com a orientação de formação rápida e maciça de quadros angolanos para se atingir os objetivos estratégicos aprovados pelo Comitê Central do MPLA, em 1976. Os objetivos eram:

1. Propiciar desenvolvimento planificado da economia, tendo a agricultura como base e a indústria como fator decisivo;

2. Edificar um Estado de Democracia Popular e construir as bases materiais e técnicas do socialismo;

3. Considerar como objetivo da produção a satisfação das necessidades das massas populares.

A questão da quantidade e do nível de qualidade dos quadros era fundamental para se pensar o desenvolvimento assente nas estratégias definidas devido, primeiro, pela saída em massa dos quadros portugueses de Angola antes da independência, depois pelo abandono do país dos quadros angolanos aliados aos outros dois movimentos de libertação, para além dos reduzidos números de pessoas formadas durante o período colonial. Por isso, uma política de educação diferenciada recomendava-se para efetivar o direito à educação dos angolanos e também para o país a curto, médio e longo prazo contasse com quadros qualificados para os seus desafios econômicos, políticos e sociais. Mas na realidade da época,

[...] não deixam de ser relevantes as implicações fortemente negativas da política adoptada para a formação de quadros sobre o desenvolvimento do país, não só num contexto de curto-prazo mas sobretudo no médio e longo prazo. Quando se define, por exemplo, que a formação deveria permitir obter quadros capazes política, cientificamente e tecnicamente (nota-se a ordem da apresentação), ou ainda quando se traçam diretivas do tipo "a política educacional da RPA terá como objetivos; formar as novas gerações e todo povo trabalhador com base na ideologia marxista-leninista" (FERREIRA, 1999, p. 25).

Entretanto, a independência não significou o fim do conflito armado. A guerra prolongou-se até 2002, com a particularidade de mudança de contendores. Na guerra para a independência, os contendores eram os três movimentos de libertação de Angola em oposição aos portugueses colonialistas, já no período pós-independência a guerra foi 
entre os três movimentos de libertação de Angola, no caso, num primeiro momento, a FNLA e a Unita em oposição aos MPLA que se constituíra governo.

Depois dos acordos da Alvor ${ }^{28}$, os movimentos de libertação não alçaram entendimentos sobre os princípios políticos e administrativos para uma Angola independente. No período imediato ao Alvor, já na vigência do governo de transição, os movimentos não chegaram a acordos definitivos sobre a governação de Angola. Essa incerteza ficou confirmada quando as divergências tomaram a forma de conflito armado. Como resultado, em 11 de novembro de 1975, duas Repúblicas foram proclamadas. Para a República Democrática de Angola, proclamada no Huambo (região centro de Angola), Almeida (2011) narra que esta República proclamada por Daniel Chipenda ${ }^{29}$, cujo governo era constituído por membros oriundos da Unita e da FNLA, durou somente entre 11 de novembro e 22 de dezembro de 1975, em razão da manifestação de antigas divergências entre os líderes dos dois movimentos coligados sobre as divergentes concepções políticas e administrativas. Todavia,

É comumente aceite que a República proclamada no Huambo se integrou com o avanço das forças cubanas para sul e a ocupação por parte destas, da cidade do Huambo em 8 de Fevereiro de 1976. [...] A sua proclamação [não foi] aceite e reconhecida internacionalmente [...] as superpotências, mais especificamente os EUA, também não reconheceram esta existência. (ALMEIDA, 2011, p. 59).

Com a desintegração dessa República e a consolidação da República Popular de Angola, os contendores da guerra civil ficaram reduzidos ao MPLA/governo e à Unita, que converteu o princípio da sua luta no combate da implantação do comunismo em Angola e a busca de democracia pluripartidária como princípios de governo para o país. Por essa disputa ter despertado os interesses das potências estrangeiras, os contendores receberam apoios na seguinte ordem: a) o MPLA foi apoiado por Cuba, que destacou milhares de militares seus e material de guerra ligeiro e pesado. Cuba mandou também para Angola médicos e professores para servirem nos sistemas de saúde e de educação, respectivamente; b) A União Soviética também esteve presente com alguns técnicos

\footnotetext{
${ }^{28}$ Acordos de Alvor: Acordos assinados em Alvor, Algarve, Portugal entre o Estado português e os movimentos de libertação nacional de Angola (FNLA, MPLA, UNITA) depois de reunidos entre 10-15 Janeiro 1975 para negociarem o processo o calendário do acesso de Angola à independência.

${ }_{29}$ Antigo vice-presidente do MPLA e líder da Revolta do Leste, facção dentro MPLA antes da independência.
} 
militares para servirem de assessores nos diferentes ramos militares, como o exército, marinha e força aérea. Os dois países assumiram também protocolos de formação de angolanos, não apenas na área militar como em vários ofícios civis. Ainda hoje, milhares de angolanos são formados em Cuba e em algumas Repúblicas da ex-União Soviética.

Pela sua opção política, a RPA autoproclama-se como "trincheira firme da revolução em África". É nessa perspectiva que Angola concede apoio ao African National Congress (ANC) ${ }^{30}$ e ao South West Africa People Organization (SWAPO) ${ }^{31}$, incluindo a abertura de delegações diplomáticas e bases militares em território angolano. O ANC, movimento nacionalista e antiapartheid, luta para o fim do apartheid na África do Sul, sendo o movimento sul-africano mais representativo da luta do povo sul africano. A SWAPO, por sua vez, lutava para a independência da Namíbia, ocupada pela África do Sul.

Esses apoios que o MPLA recebia e também concedia e o alinhamento ideológico justificam o alinhamento da África do Sul e dos Estados Unidos no conflito armado em Angola ao lado da UNITA. Os Estados Unidos viam a assistência militar a UNITA como a possibilidade de estancar a expansão do comunismo soviético e cubano. Os sulafricanos, que para além dos meios militares dispensados à Unita combatiam em território angolano com as suas forças regulares.

No decorrer dos anos, a guerra vai aumentando de intensidade e o governo vai perdendo o controlo político administrativo de algumas aéreas do território. Os efeitos da guerra vão se manifestando nos índices de vítimas humanas, na destruição de infraestruturas físicas e no uso da maior parte do orçamento do Estado para sustentar os esforços da guerra. Entretanto, vários acontecimentos no mundo, e também na região Austral de África, onde Angola se situa geográfica e politicamente, vai desencadear um clima favorável para que se negocie a paz para Angola e a adopção de um Estado democrático, multipartidário e de direito.

\footnotetext{
${ }^{30}$ Congresso Nacional Africano, na tradução para o português, governo desde o fim do apartheid em 1994, vencendo sucessivamente as eleições realizadas até o presente.

${ }^{31}$ Organização dos Povos do Sudoeste Africano, na tradução para o português, governo desde a independência em 1990 tendo vencido todas as eleições até aqui realizadas.
} 
Em 22 de dezembro 1988 são assinados os Acordos de Nova York, que no essencial determinavam a retirada dos cerca 50 mil soldados cubanos de Angola (só concretizado em 1991) que apoiavam o governo de Angola e que também facilitaram a independência da Namíbia. Em 1989, testemunhou-se na Europa a queda o muro de Berlim, "a União Soviética implodia e todo um sistema político que tinha suportado várias revoluções em África e na Ásia e América Latina desmoronava-se. Para uns, era o fim do comunismo". (ALMEIDA, 2011, p. 79, grifo do autor).

Sob esse ambiente político internacional e regional, acrescida a permanente crise econômica e social no país, que o III Congresso do MPLA/PT se realizou e criou condições para a mudança de regime político, isto é, do sistema econômico de direção central e planificada e do regime de partido único para a adopção de um sistema pluripartidário, visando um Estado democrático de direito (FERREIRA, 1999). Orientouse também nesse congresso uma revisão constitucional que deveria abranger todos os domínios da sociedade e do Estado e consagrar o princípio multipartidário e também o apoio a "decisão firme e corajosa tomada pelo Comitê Central cessante de orientar o estabelecimento de contatos diretos com a UNITA" (FERREIRA, 1999, p. 147, grifo do autor). Na sequência destes eventos, salienta-se

[...] em primeiro lugar a realização do Congresso da UNITA, em Março, que efetuou formalmente a sua passagem de partido armado para partido político; em segundo lugar, a realização, em Abril de 1991, do II Congresso Extraordinário do MPLA/PT (onde este partido voltou a chamar-se simplesmente Movimento Popular de Libertação de Angola - MPLA), marcado pelo abandono oficial da ideologia marxista-leninista e pela pugnação de uma economia de mercado e um sistema democrático multipartidário (FERREIRA, 1999, p.150).

Em 6 de maio de 1991 é publicada a Lei n.12/91, que efetua a revisão parcial da Constituição conducente a

[...] criar a abertura democrática que permita ampliar a participação organizada de todos os cidadãos na vida política nacional e na direção do Estado, ampliar o reconhecimento e proteção dos direitos, liberdades e deveres fundamentais dos cidadãos no âmbito de uma sociedade democrática, assim como consagrar constitucionalmente os princípios da reforma económica em curso, nomeadamente, aqueles que visam estimular a iniciativa e a proteção da atividade de todos os agentes económicos. (ANGOLA, 1992). 
Com a institucionalização do multipartidarismo, segue-se a assinatura, em 31 de maio de 1975, em Bicesse, Portugal, o Acordo de Paz entre o governo e a UNITA. Esse acordo previa o cessar fogo, e o consequente fim da guerra, a constituição de um exército único e a realizações de eleições gerais. Estavam assim criadas as condições para a inauguração da Segunda República em Angola, superando a anterior que vigorava desde 1975, mas, apesar de todas as alterações políticas e econômicas, não significaria o fim da guerra $^{32}$.

Quanto à abordagem da educação na Primeira República em Angola, tende-se a relacionar as decisões e opções feitas sobre a mesma com a herança do sistema colonial. Como ressalta Davidson (1974), a questão era sobre a natureza dos problemas com os quais os países emergentes da colonização portuguesa (Angola como um deles) iriam enfrentar. As respostas a esses problemas pode-se resumir no pensamento de Ferreira (2005) ao alegar que as reformas propostas para a educação não conseguiram constituirse como revolucionárias e representar as matrizes culturais dos estados africanos, sendo essas adaptações de modelos adoptados das antigas potencias colonizadoras. No caso particular de Angola,

[...] da independência ao período do multipartidarismo formal, o sistema educativo sofreu alguns sobressaltos marcados por "reformas" apressadas, desenhadas em gabinetes, sem debate público e da comunidade educativa e implementada com a rapidez dos contextos específicos das sociedades em erupção política/social (FERREIRA, 2005, p.112).

É esse sentido de abordagem que também adoptamos para este capítulo, pois a compreensão dos antecedentes históricos pode permitir também a compreensão das concepções e conteúdos da política e perceber a abordagem feita, no caso do estudo, aos fatores que concorriam para a não efetivação do direito à educação em toda a sua dimensão, isto é, acesso e ensino de qualidade. Apesar de no plano formal este período estar demarcado pela vigência da natureza da República consagrada na Constituição de 1975, e superada pela Lei Constitucional de 1992, a análise da educação vai compreender o período 1975-1991 por ser o período em que vigorou o sistema de ensino e as respectivas opções da política educacional. Esse período é sucedido pela reforma

\footnotetext{
${ }^{32}$ A guerra que é retomada depois das eleições gerais de 1992 será narrada no capítulo a seguir, devido à delimitação desenhada para este estudo.
} 
educativa de 2001, data que marca a aprovação da Lei de Bases do novo sistema de ensino. Neste capítulo, à semelhança do anterior, fazemos a apresentação da legislação e da filosofia que enformaram a educação, a estrutura que a sustentou e a análise dos fatores relacionados ao acesso, o atendimento dos alunos na escola e a natureza da educação proporcionada.

\subsection{Legislação e filosofia}

A política educacional da primeira República, no seu aspecto legal, é determinada pela Lei de Bases do Sistema de Educação e Ensino de 1978 e pela sua implementação neste mesmo ano. Essa política teve a sua gênese nas teses e resoluções do 1 Congresso do MPLA em 1977, que definiram "os princípios para a reformulação do sistema de Educação e Ensino na RPA" sob responsabilidade do Ministério da Educação (ANGOLA, 1977).

Buscando regular a educação, o Estado angolano, reconhecendo a educação como um direito, consagrou-o na Constituição. Nisso, na Lei Constitucional de 1975 (CORREIA e SOUSA, 1996) ${ }^{33}$, o seu artigo 13. ${ }^{\circ}$ diz que "A República Popular de Angola combate energicamente o analfabetismo e o obscurantismo e promove $o$ desenvolvimento de uma educação ao serviço do povo e de uma verdadeira cultura nacional, enriquecida pelas conquistas culturais e revolucionárias dos outros povos" (CORREIA e SOUSA, 1996). Com esse enunciado, a República Popular de Angola (RPA) propõe-se a responder às recomendações da Conferência da Organização da Unidade Africana (OUA) de Addis Abeba, de 1961, para que os estados independentes de África cumprissem o objetivo de tornar universal, obrigatório e gratuito o ensino primário, de modo a reverter a realidade manifesta no elevado índice de analfabetos herdado dos regimes coloniais. Para Angola, como ilustra Zau (2009), em 1950 a percentagem de analfabetismo dos negros de idade superior a 15 anos era de 97\%. Em 1973, dois anos antes da independência, num universo estimado de 14 milhões de habitantes, a população escolar era de 512.924 alunos, sendo que um terço desta eram

\footnotetext{
${ }^{33}$ A Lei Constitucional de 1975 consta na obra de Correia e Sousa (1996).
} 
"brancos" portugueses, o que demonstra permanência de índices superiores a 90\% da percentagem de negros analfabetos.

Nessa Lei Constitucional, o direito à educação é declarado no artigo 29 com a seguinte redação: “A República Popular de Angola promove e garante o acesso de todos cidadãos à instrução e à cultura" (CORREIA e SOUSA, 1996). Pode-se reter nesta declaração o acesso de todos os cidadãos à educação. Esta menção, no que se refere ao direito à educação na época, revela-se de vital relevância devido ao contexto e às políticas educacionais do período colonial em que a quase totalidade dos angolanos tinham o acesso às instituições de ensino públicas vetado, devido às condições políticas e sociais vigentes. Todavia, ao se reservar os atos do Estado em promover a educação, que interpretamos como ação de fomentar ou de criar condições para o seu desenvolvimento, notamos a não determinação da obrigação do Estado em garantir que a educação se efetive.

Para efetivar a declaração do direito à educação, o MPLA aprovou a Lei n. 4 (ANGOLA, 1975), que promovia a nacionalização da educação e a respectiva adjudicação, a favor do Estado angolano, dos centros de ensino. Aprovou também, no seu primeiro congresso de dezembro de 1977, a resolução "Princípios de Base para a Reformulação do Sistema de Educação na RPA", o alicerce da primeira reforma educativa dos sistemas de educação e ensino na RPA.

Para reforçar o acesso ao ensino, o sistema de educação e instrução foi, entre outras características, declarado gratuito e obrigatório para o ensino de base nas resoluções do congresso de 1977. A gratuidade do ensino foi realçada com as seguintes palavras do Ministério da Educação e Cultura (MEC) ${ }^{34}$ : "no seu sentido mais amplo inicialmente nem o estudante nem o seu agregado familiar pagavam quaisquer despesas com a educação, e no ensino obrigatório nem o material didático era pago [...]" (ANGOLA, 2001b, p.17).

Ainda nas resoluções, a obrigatoriedade cobria a escola de base formada por 8 classes, repartidas em 3 níveis, sendo o primeiro com quatro classes, o segundo com duas

\footnotetext{
${ }^{34}$ Neste texto, o órgão do governo que superintende a educação será designado umas vezes por Ministério da Educação e Cultura (MEC) e outras por Ministério da Educação (MED) devido às designações oficiais que tomou no decorrer da época dos documentos citados.
} 
classes e o terceiro também com duas, e abrangia a população estudantil com idades cronológicas entre os seis e catorze anos. Observamos que, quer nessa Constituição de 1975, quer nas subsequentes, e nas leis ordinárias, a obrigatoriedade não é detalhada. Partindo da análise dos textos legais, temos a percepção de que, ao assumir o provimento da educação, o Estado se intitula no dever de garantir o direito à educação, facto esse reforçado pelo artigo 30: "A República Popular de Angola deve criar condições políticas, económicas e culturais necessárias para que os cidadãos possam gozar efetivamente dos seus direitos e cumprir integralmente os seus deveres" (CORREIA e SOUSA, 1996, p 26).

Nesse cumprimento de deveres, e por se considerar a família como núcleo básico da sociedade e apesar de as obrigações da família não estarem detalhadas na constituição e na lei ordinária sobre o sistema de educação e ensino, pode-se considerar, nesse caso, uma dupla obrigatoriedade que realça, de um lado, o dever do Estado de prover este direito e, do outro, os pais ou encarregados de assegurarem que este se efetive (OLIVEIRA, 2007).

Para a efetivação do direito, previam-se também o desenvolvimento de escolas especiais e instituições para a educação dos adultos. Para o ensino especial, esperava-se, de acordo com o MPLA (ANGOLA, 1977), "fundamentalmente dar às crianças e aos jovens deficientes no seu desenvolvimento físico e psíquico, às crianças e jovens com atraso escolar as possibilidades de aquisição da instrução da base geral e profissional, tornando-os assim capazes para o trabalho ou para a vida autônoma" (p. 66). Para a educação dos adultos, aspirou-se "tornar possível aos adultos a aquisição dos elementos de base de cultura geral, de completar e aperfeiçoar a sua instrução geral e formação profissional" (p. 67).

Ao contemplarem os adultos nos programas de educação, manifesta-se a intenção de prover educação para todos. Mas, ao não se declarar a educação para este segmento como obrigatória e gratuita, pode-se refrear a obrigação dos provedores e dos beneficiários desse direito em garantirem-na. Este refreio pode lesar a pretensão de mitigar os elevados índices de analfabetismo (estimados acima de 85\% em 1975) entre a 
população adulta, analfabetismo este devido à exclusão escolar e social a que foi submetida durante o período colonial.

Outro segmento não contemplado pela obrigatoriedade da educação é o das crianças até 5 anos. Para essas estavam reservadas as creches, os jardins de infância e os jardins escola que ficavam sob a tutela da Secretaria de Estado dos Assuntos Sociais, segundo o texto das resoluções do congresso. O dever fundamental dessas instituições é o de organizar o divertimento cultural e sadio das crianças, os jogos e a vida coletiva, ajudar os pais trabalhadores, não só nos cuidados, mas também na educação dos seus filhos. Percebe-se aqui a concepção dessas instituições como estruturas de assistência social e não de carácter educativo, demonstrando, assim, que as crianças nesse segmento etário não são contempladas no direito à educação.

Na sua essência, a política educacional de 1978 buscou, na sua dimensão normativa, a transformação da finalidade dos valores por meio do desenvolvimento de uma ética (ideologia) coletiva e concorrente à vigente (VAN ZANTEN, 2011). O MPLA (ANGOLA, 1977) declarou, então, os princípios da democraticidade e da laicidade da educação, do fundamento da educação como fator de desenvolvimento integral e universal da personalidade, que se alia às necessidades da sociedade, e do direito de participação do povo no domínio da educação.

As autoridades educativas da Angola independente demonstravam, pelo menos na declaração, a sua crença em que a educação estava para a formação, essencialmente de crianças e jovens, para "[...] adquirirem os conhecimentos, as competências e as aptidões, das quais necessitam para preservarem e defenderem as instituições e os valores fundamentais da sociedade, quanto para adaptarem-se, em função da evolução das circunstâncias e do surgimento de novos desafios" (LLOYD, $1972{ }^{35}$, p. 160 apud HABTE; WAGAW, 2011, p. 818). O governo do MPLA determinou as prioridades da sua estratégia sobre a educação em conformidade com as preferências eleitas pelos movimentos nacionalistas africanos, isto é, o aprimoramento dos equipamentos e dos meios pedagógicos e o aumento da população atendida pela escola no ensino primário e

\footnotetext{
${ }^{35}$ LOYD, P. C. Africa in social change: changing traditional societies in the modern world. New York: Penguim Books, 1972.
} 
no secundário e a formação dos professores (HABTE; WAGAW, 2011). A razão, como referem os autores, funda-se no facto de, em termos gerais, os dirigentes políticos terem compreendido que para a educação desempenhar o seu papel de instrumento de descolonização mental e de desenvolvimento económico impunha-se, para além da expansão do sistema escolar, a sua reforma e adaptação ao novo contexto e necessidade dos Estados emergentes.

Quanto à dimensão cognitiva, o papel atribuído ao conhecimento na emancipação individual e no progresso social (VAN ZANTEN, 2011), percebe-se o reconhecimento declarado do papel atribuído à educação no desenvolvimento do indivíduo como membro socialmente ativo. Para o efeito, a Lei de Bases do Sistema de Educação (LBSE) de 1978 no ponto 1 do artigo $1^{\circ}$ enuncia que "a educação constitui um processo que visa preparar o indivíduo para as experiências da vida política, económica e social do país [...]”, cujo objetivo, no ensino de base, é

[...] o de dar ao aluno os conhecimentos e o mecanismo de pensamento necessário para a compreensão dos fenómenos naturais e sociais que o rodeiam, a adequada utilização dos instrumentos do conhecimento, para que possa estar apto a adquirir uma profissão quando terminar (ANGOLA, 1981a, p. 69).

A política de educação de 1978 surge num cenário de transição política no país, de colónia para país independente, e com uma organização de Estado de partido único designadamente o MPLA. Nesse contexto, as redes de relações que sustentaram a política foram essencialmente o partido político em si e os protocolos de cooperação rubricados com países aliados. O governo de Angola direcionou os fundamentos da educação para as lógicas dos países do bloco do leste europeu, nomeadamente a União das Repúblicas Socialistas Soviéticas (URSS), a República Democrática Alemã (RDA), a Bulgária, e de outros países do bloco socialista como Cuba e Vietnam, a fim de legitimar as políticas de educação. Ngaba (2012) constata que esta presença é visível tanto na programação como na análise de problemas e nas soluções recomendadas. Essa presença foi garantida pelas comissões mistas entre Angola e cada um desses países e também pelos congressos dos ministros da educação dos países socialistas. 
Quanto às realidades visadas pela política educacional nesse período, essa reforma buscou, entre outros objetivos, a construção de um sistema de educação que se demarcasse das práticas educativas vigentes no período colonial, práticas estas que não se harmonizavam com os propósitos da educação projetados para a sociedade que se pretendia instituir. A objecção à educação colonial deveu-se à natureza discriminatória e alienadora, propensa a formar mão de obra para apenas servir aos seus intentos colonialistas e à inculcação de ensinamentos destinados a anular um conjunto de saberes e a civilização dos povos nativos. Essa educação resumiu sua ênfase na redução dos educandos à condição de objetos moldados, numa relação autoritária e de imposição da subjetividade alheia aos educandos, situação que privilegia a dominação e prejudica o cultivo de uma condição de sujeitos fundada numa relação dialógica entre autores e vontades próprias (PARO, 2010).

Declarada como objetivo estratégico, e nessa sua dimensão política, a educação proposta enfatizou a implantação da democracia popular e a consolidação de uma sociedade pautada pelos princípios do socialismo. Para consumar esse objetivo estratégico, a política traçou um sistema de educação norteado pelos seguintes princípios: democrático, unicidade (orientação, estruturas, planos e programas, etc.), gratuidade do ensino, a obrigatoriedade do ensino de base, laicidade da educação e a participação do povo no domínio da educação (ANGOLA, 1977).

Todavia, essas dimensões propostas pela política de educação desse período, pautadas pela visão de partido único, mostraram-se contrárias aos ideais de uma educação democrática quando da sua materialização. Na sua essência, a educação democrática não deve ser resumida à declaração do acesso indiscriminado dos cidadãos à educação como política pública. Ela não deve também limitar-se a uma declaração formal nos dispositivos legais.

A participação, por exemplo, na vida das escolas e em outras instituições similares, é tida, nesta política, como uma necessidade devido ao facto de as atividades das escolas serem de significado social particular. Convoca-se, para o efeito, a participação ativa de todo cidadão angolano, dos representantes das organizações e sectores interessados e da sociedade no geral na vida da escola. Entretanto, na escola 
pública desse período histórico da sociedade angolana, determinava-se, como ilustra o manual do curso de formação de professores de 1981, que na lógica da responsabilização no interior da escola, "todo problema da direção da escola recai sobre uma pessoa: o diretor" (ANGOLA, 1981b, p. 20). Ao diretor, ainda segundo o documento que vimos citando:

[...] compete [...] a responsabilidade da organização total da escola e é a pessoa que deve responder pelo cumprimento de todas as tarefas da mesma. Deve criar condições para que o processo docente educativo, e todo o trabalho ideológico se desenvolve, eficientemente. Deve saber apoiar-se em todo o coletivo das escola e coordenar as tarefas com as organizações políticas de massas, para impulsionar a sua execução, tendo sempre a máxima responsabilidade pelos resultados. (ANGOLA, 1981b, p. 22).

$\mathrm{Na}$ sua função política, o diretor era definido como um quadro político que respondia perante o MPLA e o governo pelo cumprimento dos fins da educação. Valorizando a centralização e a hierarquização, o diretor era essencialmente reduzido a funcionário burocrático do Estado a quem respondia pela legitimação das pretensões da elite dirigente. Contrariando a essência do trabalho pedagógico, o diretor resumia o seu trabalho no controlo da conformação das atividades na escola às ordens passadas. Mas, como muitos diretores não entendiam os fundamentos dos fins da educação propostos, o trabalho dos mesmos reduzia-se ao acompanhamento do calendário escolar e a aplicação das atividades propostas.

O princípio democrático da educação num sistema público de educação deve pautar-se, como sustenta Paro (2001 e 2007), essencialmente em conferir aos cidadãos atributos que lhes permitam ter uma participação ativa na vida pública e fazer com que a escola se configure democrática em suas ações para atender aos interesses de quem ela deve servir. Em suma, conforme realçam Valente e Arelaro (2002), a educação democrática deve implicar:

a) a garantia do acesso de todos à escola;

b) o princípio de que todos devem ter condições de permanecer na escola com condições de um aprendizado efetivo;

c) a necessidade de que a educação escolar expresse o conceito de qualidade de ensino socialmente construído; 
d) a definição dos rumos da educação, como fruto da ação e da vontade coletiva, através de uma gestão efetivamente democrática e plural.

À semelhança do contexto colonial, a educação foi também instrumentalizada nesse período para, como afirma Vieira (2004), homogeneizar a sociedade angolana, isto é, se no contexto colonial esse processo foi uma forma de desenvolver uma educação que afastasse os angolanos das suas tradições culturais, no contexto de partido único, a educação foi adoptada como um meio de idealização da sociedade. É possível compreender os intentos da instrumentalização da educação para o projeto ideológico da época por meio da concepção elaborada para a educação: um meio de transmissão de conhecimentos, ideias, opiniões, crenças e costumes. Além disso, também havia uma influência sistemática com um sentido e um fim determinado para desenvolver no educando qualidades desejadas pelo educador e, também, a ação de inculcar determinada concepção do mundo e determinada moralidade.

A educação na sua dimensão moral, sustenta-se e também sustenta uma determinada ideologia, o que a torna necessariamente ideológica. No entanto, nos contextos de democratização da educação para que a mesma efetive o direito à educação, a questão é até que ponto a ideologia que sustenta a educação não é ela própria um instrumento de dominação, logo, pernicioso aos ideais da realidade que busca a sua transformação. Reconhecemos a educação como parte de uma ideologia, mas advogamos que ela deve salvaguardar um projeto maior da nação e não a substituição da natureza da dominação e sua reprodução, pela educação, numa determinada realidade, e nesse caso para Angola como República que se edifica.

Sem reduzirmos o conceito a esta perspectiva, salvaguardando aos demais conceitos nos quais ele é operacionalizado, tomamos o conceito de Eagleton (1997), que aproxima ideologia ao conceito de cultura no seu sentido amplo, e por o próprio autor o considerar politicamente neutro, e também porque a ideologia envolve a relação entre os signos e os processos do poder político. Na óptica de Eagleton (1997), a ideologia, ou cultura, congrega as múltiplas práticas significantes e os processos simbólicos que ocorrem numa sociedade específica. Ela traduziria a maneira de os indivíduos “vivenciarem suas práticas sociais, mais do que as próprias práticas, que seriam o âmbito 
da política, da economia, da teoria da afinidade, etc.” (EAGLETON, 1997, p. 38). É sob essa perspectiva que retomamos o conceito de ideologia como "um conjunto de crenças que reúne e inspira um grupo ou classe específica a perseguir interesses políticos considerados desejáveis" (EAGLETON, 1997, p. 50).

Em Angola, o projeto político pensado para a República assentou na ideologia socialista sustentada pelas visões do marxismo-leninismo para a sua operacionalização na realidade idealizada pelo grupo político, MPLA, a fim de consumar os seus interesses numa sociedade que reproduziria a teoria marxista da formação social, que vemos como o modelo estruturado da sociedade com uma base económica e a superestrutura política e ideológica. É conveniente realçar, e apoiamo-nos em Newman (2005), que o socialismo tem como principal compromisso a criação de sociedades igualitárias e promotoras do bem-estar social pela eliminação da pobreza e das desigualdades estruturais presentes nas esferas sociais, económicas e do poder político. A igualdade almejada deve celebrar a diversidade e a diferença presentes numa determinada sociedade.

Tendo-se dado num contexto no qual os colonizadores tinham deixado o país, e com a proclamação da independência, o MPLA superou os seus oponentes políticos e consignatários dos Acordos de Alvor para a constituição da República e respectiva proclamação da independência. O projeto político do MPLA não se submeteu à necessidade de provar a sua validade e adequação para os intentos da República. A implementação da sua ideologia buscou, parafraseando Taras (1984), a realização social desejada, à luz da sua teoria política da formação social. O desafio nesta fase, na ausência de oponentes políticos nas questões de governação ${ }^{36}$ e devido às contingências da ordem mundial, a existência de dois blocos políticos que participaram intensamente nas disputas políticas em Angola, o principal desafio não foi a socialização dos sectores da economia, mas sim a mobilização de apoios políticos da sociedade para a sua causa, e também consolidar o domínio político do país. É com esse desafio em mente que várias forças e instrumentos foram mobilizados. A educação foi um desses instrumentos.

\footnotetext{
${ }^{36}$ Salientamos o facto de que, apesar de o MPLA ter proclamado a independência e formado governo de partido único em 1975, os outros contendores políticos partiram para a resistência armada ao governo do MPLA, particularmente a Unita, que prolongou a sua ação militar até 2002.
} 
Para o MPLA, a escola herdada não correspondia aos interesses do povo angolano, e não estava concebida e estruturada segundo os princípios do marxismoleninismo porque nas sociedades socialistas as mudanças ocorrem pela base das relações sociais das quais depende também o carácter da educação e da instrução.

É nessa perspectiva que o MPLA, no que tomamos como objetivo declarado da educação, invoca que

[...] o nosso sistema de educação e de instrução deve edificar-se e desenvolverse no sentido dos objetivos gerais da nossa revolução (consolidação da independência para o poder popular e a construção do socialismo) a fim de poder contribuir no máximo para a realização dos bens materiais e culturais e para a construção das relações sociais socialistas. (ANGOLA, 1977, p. 50-51).

Para que esse objetivo da educação se efetivasse, o MPLA acreditava que a política educacional devia-se fundar nas premissas do socialismo científico como ideologia e concepção do mundo, ao serviço da instalação da democracia popular e a construção do socialismo. O MPLA, segundo os mesmos, buscava alinhar o seu pensamento aos ideais socialistas que, representados essencialmente pelos socialistas, confiaram na educação como instrumento de transformação social, uma vez que "a emancipação dos indivíduos, sua libertação das condições opressoras, só poderia se dar quando tal emancipação alcançasse todos os níveis e, entre eles, o da consciência [... porquanto] somente a educação, a ciência e a extensão do conhecimento, o desenvolvimento da razão, pode conseguir tal objetivo" (MARX; ENGELS, 2006, p.10).

Porém, para se alcançar este desiderato impunha-se, o que de facto foi feito, a crítica à escola colonial a fim de se promover a sua mudança, mas a mudança não pode confluir numa política de imposição de um modelo uniforme de pensar. Os fatores fundamentais da educação como direito, já evocados, devem ser elevados ao topo da agenda das políticas da educação como força que promove a transformação social. Ao contrário, a educação continua a ser um dos meios fundamentais de dominação ideológica e consequentemente um instrumento para consolidar a hegemonia da classe no poder (MARX; ENGELS, 2006, p. 17). Recomenda-se por isso a não centralização e a não manipulação da educação, quer nos critérios e processos da definição da sua agenda e fins, quer nos seus processos de gestão nos vários níveis em que ela se dá, porque senão, 
como esperar que uma sociedade igualitária e livre emerja de uma lógica organizacional autoritária (NEWMAN, 2005).

Louis Althusser (1996) discorre sobre os riscos de a educação assumir um papel de dominação ao serviço de minorias detentoras de poder, logo, perniciosa para os intentos das transformações sociais advogadas para uma sociedade socialista, bem como as condições em que ocorre essa manipulação ideológica da educação, socorrendo-se, como ilustração, os processos de reprodução da qualificação da força de trabalho nas sociedades capitalistas. A escola, para o autor, no seu sentido mais restrito, promove o aprendizado da leitura, da escrita e do cálculo, da literatura e da cultura científica. Mas, continua o autor, além dessas técnicas e conhecimentos, molda o comportamento dentro das normas estabelecidas para que cada agente se conforme ao seu papel na divisão do trabalho. Nessa realidade, o agente observa regras de moral, consciência cívica e profissional para corresponder à norma de ordem estabelecida pela dominação de classes.

Nesse processo, "a reprodução da força de trabalho requer não apenas uma reprodução de sua qualificação, mas também, ao mesmo tempo, uma reprodução de sua submissão à ideologia vigente" (ALTHUSSER, 1996, p. 6). Para que tal aconteça, a escola como aparelho ideológico do Estado, segundo o autor, é forçada a reproduzir a ideologia da classe dominante porque é pelos aparelhos ideológicos do Estado que essa ideologia é realizada e se torna a dominante.

Essa concepção da educação, para a submissão, a dominação e a reprodução, perverte seus próprios fins ao não cultivar valores que reconheçam que, no processo de ensino-aprendizagem, o ato de desenvolvimento progressivo da personalidade requer de cada educando, recapitulando Mondolfo (1967), o "exercício ativo e constante de sua liberdade, muito mais do que o possa exigir a simples conservação e defesa de uma condição já alcançada" (p. 52). No caso da educação angolana, essa condição seria a reprodução e a conservação dos princípios "importados" do socialismo marxistaleninista. Ainda na sua dimensão, o sistema de ensino, como resultado da ideologia reinante, continuou com a prática da negação da singularidade de outrem a favor da adequação dos cidadãos aos ditames da ideologia adoptada para privilegiar o "transmitir", “influenciar” e "inculcar” visões preconcebidas e de sentido unilateral (VIEIRA, 2004). 
Acrescido aos intentos da educação acima referidos, a política educativa procurou aliar-se aos valores da educação, manifestos nos princípios dos movimentos nacionalistas que visaram "africanizar" a educação para se livrar das falsas ideias herdadas dos fins perseguidos pela escola colonial. A escola constituída deveria integrar a educação ocidental disseminada nas formas tradicionais da educação africana; concebê-la para promover a moral e a consolidação de princípios de uma nova sociedade unida, igualitária e baseada num conceito de justiça social; em suma, uma educação à medida das necessidades práticas e imediatas da sociedade (HABTE; WAGAW, 2011).

Podemos constatar que a educação pensada para as diferentes etapas da luta pela libertação do continente africano deveria essencialmente visar a libertação do continente e dos seus povos das lógicas coloniais presentes nas relações sociais e económicas, recuperar a história, as experiências, os valores, as línguas, em suma, a cultura em seu sentido amplo, e inseri-la na nova escola para sustentar ideologicamente o modelo de sociedade assente na igualdade e na justiça social, e contribuir na promoção do desenvolvimento económico.

Nos pressupostos da libertação colonial, Amílcar Cabral (1973, p. 43) declarou que a "libertação é necessariamente um ato de cultura". Para ele, a libertação cultural dos povos sob o domínio colonial dar-se-ia apenas caso esses povos, sem complexos e sem subestimar os valores da cultura do opressor, bem como a de outros povos, se dedicassem a revalorizar a sua cultura em função da sua realidade concreta. Nisso, Amílcar Cabral insta os movimentos de libertação a estarem conscientes do facto de, sejam quais forem as condições materiais da sociedade que representarem, a sociedade ser o portador e o criador da cultura. Entendendo assim que a produção cultural brota da sociedade e não como um projeto político ideológico alienado das massas populares, e detido por uma elite que, a seu modo, busca perpetuar o processo de dominação. Para o efeito, a cultura como ato de libertação nacional deve valorizar a diversidade e as diferenças culturais para que ela tenha significado para os diferentes grupos sociais e a cada indivíduo nelas presentes ao garantir a estes indivíduos "a compreensão e a integração ao seu ambiente, a identificação com os problemas e aspirações fundamentais da sociedade, a aceitação da possibilidade de mudança rumo ao progresso" (CABRAL, 1973, p. 44, grifos do autor). 
Nessa perspectiva, e levando em consideração o contexto da luta de libertação, a concepção da cultura como ato de libertação e interpretada como o fim da educação como processo social, acreditamos que se responde o desafio colocado por Julius Nyerere aos países africanos nos seus processos de libertação, no que à educação diz respeito, segundo o qual a concepção dos sistemas de educação para servirem os propósitos dos Estados somente serão reais e eficazes quando os Estados estiverem conscientes das sociedades pretendidas.

Ainda como elemento da luta da libertação para uma nova ordem que contrapunha a colonial, Herbert Vilakazi (2000) afirma que o maior desafio à educação em África era o de contrapor, primeiro, a negação pelos colonizadores do estatuto de civilização aos africanos se comparado à China, à Índia e ao Ocidente tomados como civilizações. Devido a este estatuto, ao falarmos dessas sociedades (as com civilizações) temos em mente

[...] um conjunto de culturas, língua ou línguas, religião, uma visão do mundo, um padrão de experiências históricas, uma determinada tecnologia e o modo do seu uso, e um padrão identificável na arte, música, um determinado corpo de conhecimento, ciência, medicina e valores, uma determinada culinária e vestuário e os hábitos no seu todo, etc. (VILAKAZI, 2000, p. 196).

Por essa razão, insta o autor, o sistema de educação em África deve desenvolverse tendo como fundamentos, e também desenvolver, a sua própria civilização, que esta inclua a quase totalidade dos seus cidadãos.

Sobre a libertação, Paulo Freire e Sérgio Guimarães (2003) enfatizam que a liberdade é algo que se cria e recria historicamente, por isso, nunca se é totalmente livre, mas está-se sempre em processo de libertação. Assim, ao refletir sobre a realidade dos ideais de educação das ex-colónias portuguesas em África (Angola, Moçambique, GuinéBissau, Cabo Verde e São Tomé e Príncipe) nos meses imediatos a suas independências, os autores relembram que

[...] as experiências revelaram também que nem sempre o fundamental, num trabalho de educação popular é ensinar a ler e a escrever a palavra, mas o fundamental é "ler", "reler" e "reescrever", com aspas, a realidade. Isto é desenvolver uma compreensão crítica do próprio processo histórico político, cultural, económico e social em que as massas estão inseridas (FREIRE e GUIMARÃES, 2003, p. 50-51). 
É esse pressuposto da compreensão crítica do processo histórico, cultural, económico e social que nos reconduz à cultura como fundamento da educação. Entendido assim, as visões que fundam o sistema de educação para os Estados africanos, para além do seu ajuste à dinâmica do contexto mundial, deve reconhecer que os saberes africanos dão a situações relativas às necessidades históricas, culturais e ambientais inerentes à condição do seu povo (ABDI, 2005). A crença no valor dos sabres africanos que sustentavam a educação nas sociedades pré-coloniais deve-se ao facto de, segundo Abdi,

As filosofias africanas da educação [...] estavam centradas na transformação das sociedades para as vias mais adequadas que não fossem contra a comunidade e nocivas a coesão e integridade do seu ambiente. Neste sentido, essas filosofias eram necessariamente centradas, não na noção para se vencer uma contenda, mas nas necessidades da vida dos africanos (ABDI, 2005, p. $32)$.

$\mathrm{Na}$ verdade, esperava-se que a educação para o contexto africano buscasse perspectivas e entendimentos sobre as necessidades educativas dos alunos a ela submetidas para que ela se tornasse relevante e inclusiva, para os alunos, e prática e produtiva, para a comunidade. Em síntese, uma educação assente, como a define Shizha (2005), na narrativa da(s) nação(ões). Porque, para o autor, estas narrativas "provêm um conjunto de histórias, imagens, eventos históricos, símbolos nacionais, e rituais que se relacionam as sociedades e representam as experiências partilhadas que conferem significados às sociedades africanas" (SHIZHA, 2005, p. 67).

Essas narrativas já estiveram presentes na escola africana pré-colonial. O conhecimento sobre a maneira como a escola (educação) operacionalizava as mesmas narrativas é valor carecido no processo da edificação dos sistemas de educação nos Estados africanos independentes, se atendermos à necessidade de uma escola que busca a valorização e a recriação dos valores africanos bem como a emancipação dos africanos na luta pela libertação contra a alienação cultural proporcionada pelas políticas educativas coloniais.

Ociti (1973) apud Adeyinka (2006) identifica e define os princípios nos quais se fundaram a educação na África pré-colonial, que são: o preparacionismo, o 
funcionalismo, o comunitarismo, o perenialismo e o holístico ${ }^{37}$. Esses são explicados da seguinte maneira:

- Preparacionismo: abrangendo a educação formal e informal, este princípio implicava que o papel do ensino e da aprendizagem é o de equipar os rapazes e as meninas com habilidades para desempenharem tarefas a eles prescritas em função dos diferentes papeis sociais a desempenhar. Nas sociedades pré-coloniais, a educação assentava no gênero e prescrevia as funções em masculinas e femininas. Na essência visa-se a preparação dos recipientes da educação a ajustarem-se à sua comunidade e nelas desempenharem tarefas relevantes. "As crianças desenvolviam um sentido de compromisso com a comunidade e aprendiam a apreciar história, língua, costumes e valores” (ADEYINKA, 2006, p. 443).

- Funcionalismo: este conferia o caráter participativo à educação em que as pessoas aprendiam pela imitação, cerimonias de iniciação, trabalho, jogos, literatura oral, entre outros métodos. Por essa via, "o educador era produtivo enquanto ele/ela aprendia e era aos poucos integrado na comunidade [...] Não havia desemprego nas sociedades tradicionais africanas" (ADEYINKA, 2006, p. 443).

- Comunitarismo: existia na comunidade o sentido de propriedade coletiva, e também aplicava-se o espirito comunitário nos princípios da vida e do trabalho. "As crianças pertenciam à comunidade e cada membro da comunidade tinha a sua responsabilidade no processo de crescimento destas crianças" (ADEYINKA, 2006, p.444).

- Perenialismo: a educação na maior parte das sociedades tradicionais africanas era conservadora. Ela era encarada como o veículo para a manutenção ou preservação da cultura e do status quo.

- Holístico: devido ao facto de a grande maioria das sociedades africanas não serem suficientemente "desenvolvidas", a educação conferiu pouco ou quase

\footnotetext{
${ }^{37}$ Tradução livre do inglês: preparationalism, functionalism, communalism, perennialism, holisticism.
} 
nenhuma especialização, mas dotava os alunos de habilidades para múltiplos ofícios. A perspectiva era tornar as crianças produtivas de maneira distintas.

A caracterização dos sistemas de educação na África pré-colonial, na perspectiva de Ki-Zerbo (1990), é resumida no quadro a seguir, vistos os seus aspectos negativos e as suas vantagens.

\section{Quadro 3: Sistemas de educação na África pré-colonial}

\begin{tabular}{|c|c|}
\hline Desvantagens & Vantagens \\
\hline $\begin{array}{l}\text { * Baixo nível de generalização e abstração, o que } \\
\text { condicionou o progresso científico. } \\
\text { * Baixo coeficiente de acumulação e } \\
\text { disseminação dos saberes. } \\
\text { * Sistema relativamente hermenêutico, } \\
\text { circunscrito a etnias, aldeias ou comunidades } \\
\text { particulares. } \\
\text { * Os excessos nos rituais educativos, como o de } \\
\text { iniciação, que às vezes resultavam em mutilações } \\
\text { e/ou mortes. }\end{array}$ & $\begin{array}{l}\text { * Relação intrínseca entre os conhecimentos } \\
\text { gerais e a vida prática. } \\
\text { * Processo educativo ligado à produção e } \\
\text { incorporando as componentes simbólicas e } \\
\text { ideológicas. } \\
\text { * Processo educativo ligado à vida social e } \\
\text { incorporando valores e redes de relações de } \\
\text { salvaguarda das identidades pessoais e coletivas. } \\
\text { * Sistema democrático, valorizando os diferentes } \\
\text { atores e formas de conhecimentos. } \\
\text { * Sistema de educação assente na cultura ao } \\
\text { promover as línguas locais, jogos, rituais, dança, } \\
\text { música, desporto, etc. } \\
\text { * Relação clara entre o processo educativo e os } \\
\text { valores éticos. }\end{array}$ \\
\hline
\end{tabular}

Fonte: Adaptado de Ki-Zerbo, 1990

Por essa razão, Ki-Zerbo (1990) recomendou a reflexão sobre a educação numa perspectiva que levasse em consideração todas as dimensões das aspirações do homem tomado como o fim e o agente do desenvolvimento. A definição dos objetivos da educação, continua Ki-Zerbo, não deve simplesmente visar os padrões económicos, mas deve considerar os valores e as aspirações dos indivíduos, das suas comunidades, enfim, da humanidade no seu todo.

Todavia, comprometida em construir "o seu Estado socialista" e, acima de tudo, exercer o controlo absoluto sobre a sociedade à luz da sua ideologia, a escola em Angola afastou-se da doutrina que o próprio MPLA, como movimento, propôs aos angolanos durante a luta de libertação. Por exemplo, a necessidade de salvaguardar as formas 
tradicionais da educação africana esbarrou no exercício de "modernizar" a sociedade angolana. A política do combate ao obscurantismo redundou na pretensão da eliminação na sociedade angolana das práticas culturais relacionadas a ritos de iniciação, medicina tradicional, crenças religiosas e, principalmente, o uso das línguas locais era interpretado como refratário ao projeto cultural da sociedade do novo regime por na sua interpretação manifestarem o tribalismo e o regionalismo. Bittencourt (2010) a propósito aponta que as tradições pré-coloniais passam a ser analisadas tendo em conta os conceitos de classe social e modo de produção. As tradições já consideradas territórios seguro para o combate ao colonialismo, e esperadas como substrato da nova sociedade são postas em causa. "A construção da nova nação implicaria o fim das etnias, dos regionalismos, do racismo, da exploração do homem pelo homem [...] O tradicional passa a ser visto, em muitos casos, como atrasado e refratário ao novo poder" (BITTENCOURT, 2010, p. 139). Como também o autor afirma, a aludida luta contra o obscurantismo e o tribalismo acaba por visar também a tradição.

A persistência da escolarização apenas na língua portuguesa, herdada do colono e declarada língua oficial na RPA, atuou como um elemento de seleção e de eliminação dos efetivos escolares. O domínio elementar da língua portuguesa era reservado a uma minoria de angolanos maioritariamente concentrados nos centros urbanos. Dada a elevada percentagem de alunos provenientes das regiões rurais, o ensino na língua portuguesa era um obstáculo para a aprendizagem. A língua é o sintoma que mais se sobressai sobre a orientação ocidental da educação na África independente. Elas, as línguas africanas, foram banidas dos sistemas educativos por se entender que são fatores de tribalismo (ALMAFTI, 1997).

Brock-Utne (2000) convoca-nos à reflexão sobre a relevância da língua de instrução ao afirmar que "o conceito de 'educação para todos' torna-se num conceito completamente vazio caso o ambiente linguístico dos alunos não for levado com consideração" (p. 141). Para o caso particular de África, reporta-se que um dos maiores problemas que afeta o aprendizado das crianças é o facto de o ensino ser desenvolvido numa língua que normalmente não é usada no seu ambiente imediato, sendo, em muitos casos, uma língua que não é do domínio nem uso corrente quer do aluno quer do próprio professor. Para o aluno, esse facto é uma barreira ao seu aprendizado. 
Constitui-se numa barreira porque, nas classes iniciais, fase em que as crianças adquirem a literácia básica e ajustam-se às demandas da escola, o domínio da língua determina o sucesso ou insucesso do mesmo, traduzido, na aprovação ou reprovação, ou ainda na permanência ou abandono escolar (BROCK-UTNE, 2000). Como adianta Heugh (2011), dificilmente são relevantes os resultados esperados para o aprendizado de uma criança que aprende uma nova língua como disciplina, ao mesmo tempo que essa língua é usada como meio de ensino e aprendizado. A persistência nesta pratica resulta no não domínio da nova língua, nem as matérias de outras disciplinas ensinadas nessa língua.

Em regra, à qual Angola não se exclui, nas sociedades africanas pós-coloniais o fator linguístico, entendido aqui como a língua de instrução, fomenta o julgamento autoritário que cataloga as crianças como "não inteligentes" e "inadequadas" para as exigências da escola. Efetivamente, é o desconhecimento da língua de instrução que os separa da compreensão e da recriação dos conteúdos da educação escolar formal. No quotidiano de muitas crianças, a língua de instrução, o português no caso Angolano, está presente nas interações formais do mundo dos adultos, estando por isso as crianças ausentes nas interações linguísticas associadas à língua de instrução. Nessa condição, a sala de aula e os atos relacionados à aula constituem-se aos poucos realidades nas quais elas experimentam o uso da língua oficial.

Para Shizha (2005), as línguas de instrução nas realidades das escolas em África são de facto o maior obstáculo para o desenvolvimento cognitivo das crianças e também dos resultados da aprendizagem. Justifica-se o autor com o facto de o conhecimento estar incorporado na língua. Ao serem instruídos numa língua "estrangeira”, os alunos, nas escolas africanas, são obrigados a recorrer à tradução para construírem sentidos no conteúdo que lhes é apresentado para a aprendizagem. Este exercício ocorre devido à natural conexão entre a língua, à construção dos sentidos e aos atos práticos. Indubitavelmente, “o uso de línguas 'estrangeiras' como as únicas línguas de instrução desvia a educação da cultura africana nativa e ignora virtualmente os valores e crenças nativas que poderiam auxiliar e elevar a compreensão dos alunos” (SHIZHA, 2005, p. $80)$. 
Essa realidade transforma a questão do ensino em línguas não familiares aos alunos numa preocupação contínua, ademais quando, como advoga Probyn (2005), elas contribuem para os baixos índices de promoção nas escolas africanas e também atuam como obstáculo ao acesso equitativo ao currículo e às experiências que ele proporciona.

No entanto, as línguas estrangeiras continuam presentes nos sistemas de educação da grande maioria dos países africanos como o principal, e praticamente o único, instrumento linguístico de instrução. A razão dessa realidade é por norma justificada, segundo Brock-Utne (2000), Hizilda (2006) e Freire e Guimarães (2003), pela existência de múltiplas línguas locais, sendo que a escolha de uma ou duas delas poderiam fomentar conflitos nas respectivas sociedades. Acrescenta-se também a questão dos custos financeiros, considerados elevados, envolvidos num programa de redefinição da política linguística, envolvendo a produção de material impresso, estudos e pesquisas afins. Outra justificação enraizada em defesa da manutenção da língua dos antigos colonizadores é a garantia do acesso ao emprego e também o acesso à tecnologia e aos programas de modernização. Em suma, as questões socioculturais, políticas, económicas, educacionais e sociolinguísticas inter-relacionam-se.

Rebatendo essas teses, Brock-Utne (2000) resume as principais razões que fundamentam a adopção do ensino das línguas nativas africanas no ensino. Essas razões foram definidas num encontro de Ministros da Educação africanos sobre o uso das línguas africanas na educação, em 1982, em Harare, Zimbabwe. A primeira razão evocada é a questão do compromisso dos Estados africanos com o desenvolvimento. Esse desenvolvimento deveria essencialmente promover e sustentar a unidade nacional, o desenvolvimento social, económico e social; sendo o desenvolvimento cultural a condição básica para que os outros dois aconteçam. Devido à sua condição de instrumento vivo da cultura, requer-se que a língua se desenvolva para, primeiro, sustar o desenvolvimento cultural e também ao desenvolver a sua condição de instrumento de comunicação e mediador das relações sociais, económicas e políticas, a língua propicia o desenvolvimento social e económico.

A outra razão é o aspecto sociopolítico. A questão da língua na educação é associada à questão da soberania dos Estados na relação com as antigas potências 
colonizadoras, bem como a reconquista da sua identidade cultural por séculos negada e deturpada pelos Estados colonizadores. Retoma-se também aqui o facto de a língua de instrução estar intrinsecamente relacionada aos diferentes fatores que afetam a efetivação da educação como um direito de cidadania nos Estados africanos independentes.

A questão das línguas nacionais não preocupa apenas os estudiosos. Ela tem sido também desde as primeiras independências de África (década de 1950) uma preocupação da organização continental (OUA) e também das várias organizações de âmbito regional cujos encontros produzem princípios e recomendações relativas à disseminação do uso das referidas línguas. Por exemplo, o encontro de Harare (1997), entre outras conclusões, realça que a promoção do uso das línguas nacionais concorre para o fomento da democracia como incentivador da participação de todos os cidadãos em todas as instituições - sociais, econômicas e políticas. E o encontro de Asmara (2000) produziu as seguintes indicações:

- A vitalidade e a igualdade das línguas africanas como base para o empoderamento dos povos africanos;

- As línguas africanas são vitais para o desenvolvimento da democracia baseada na igualdade e na justiça social;

- As línguas africanas são essenciais para a descolonização do espírito africano e para o renascimento africano;

- É direito de a criança ir à escola e aprender a sua língua.

No quadro a seguir, apresentamos alguns dos principais instrumentos sobre as línguas africanas produzidos no âmbito da agenda da OUA sobre a questão. Salienta-se o facto do espaço temporal, 51 anos, que a questão está presente na agenda. Quanto à questão linguística em si, há uma certa mobilidade do foco da questão que se vai ajustando com as agendas econômicas e políticas que se vão manifestando. Se as primeiras declarações focam a questão do reconhecimento das línguas nativas, as últimas já relacionam as línguas ao desenvolvimento social e econômico das sociedades e a consolidação das democracias e da justiça social nos Estados africanos. 
Quadro 6: Instrumentos africanos sobre as línguas africanas

1. Carta da Organização da Unidade Africana (1963)

2. Manifesto cultural Pan-Africano de Alger (1969)

3. Conferência Intergovernamental sobre políticas culturais em África, organizada pela Unesco em Accra, Ghana (1975), em cooperação com a OUA

4. Carta Cultural Africana (1976) adoptado pela OUA

5. Plano de Ação de Lagos (1980) para o desenvolvimento econômico de África

6. Relatório final da Reunião dos Expertos da Unesco sobre "a definição da estratégia para a promoção das línguas africanas" (1982)

7. Plano de Ação Linguístico para África, definido pela OUA (1986)

8. Esboço da Carta para a Promoção das Línguas Africanas na Educação (Produzida pelo seminário Pan-Africano organizado em Accra, Ghana, 1996)

9. Declaração de Harare da Conferência intergovernamental sobre as políticas linguísticas em África (1997)

10. Plano de Ação da Conferência intergovernamental da política linguística em África (1997)

11. Declaração de Asmara sobre línguas e literaturas (2000)

12. Declaração de Maputo (2006)

Fonte: o pesquisador

\subsection{O Acesso}

A negação do acesso à educação é um dos primeiros fatores para a negação desse direito. Ao não se proporcionar escolas para os cidadãos de uma determinada comunidade ou grupo, é vetada a condição básica para que a educação escolar formal como um processo consciente, conducente a um fim com valor social, se efetive. Estando o governo do MPLA interessado em incumbir à escola a missão de sustentar a sociedade assente nos princípios do marxismo-leninismo, por um lado, e a garantia do compromisso 
de oferecer educação para os angolanos, por outro lado, antes condicionada pelos governos coloniais, concebeu um sistema de educação fundado, dentre outros princípios, na gratuidade, na obrigatoriedade e na laicidade, bem como na democraticidade para a que educação abrangesse o cidadão independentemente da sua condição socioeconómica.

Com esses princípios, as autoridades educativas demonstravam a intenção de eliminar algumas barreiras que condicionavam o acesso à educação. Como resultado desta proposta, verifica-se um natural crescimento dos efetivos escolares no sistema de educação. Dados apresentados no seu primeiro congresso em 1977, o MPLA mostra que houve uma explosão escolar por os efetivos, por exemplo, dos 512.924 alunos matriculados em todos os níveis existentes em 1973 crescerem em 1977 para 1.026.291 alunos, no ensino primário, e 105.358 para o ensino secundário, crescimento este que foi apresentando outros contornos com o passar dos anos. No ensino primário, nível coberto pela escolaridade obrigatória, os efetivos escolares estavam distribuídos como mostra o quadro que se segue.

Tabela 7 : Efetivos escolares no ensino primário (1977)

\begin{tabular}{|c|c|c|}
\hline Classe & Percentagem & $\begin{array}{c}\text { N. aproximado de } \\
\text { alunos }\end{array}$ \\
\hline Pré-Primária & $39,2 \%$ & 402.306 \\
\hline 1 . $^{\mathrm{a}}$ classe & $29,0 \%$ & 297.624 \\
\hline $2{ }^{\mathrm{a}}$ classe & $15,7 \%$ & 161.128 \\
\hline $3 .^{\mathrm{a}}$ classe & $9,3 \%$ & 95.445 \\
\hline $4 .{ }^{\mathrm{a}}$ classe & $6,8 \%$ & 69.788 \\
\hline
\end{tabular}

Fonte: Angola (1977)

Constata-se a concentração de alunos nas classes iniciais, concretamente na PréPrimária, a iniciação, e também na primeira classe. Não sendo a população estudantil completamente nova, o reduzido número de população estudantil nas duas últimas classes deste nível, a 3. ${ }^{a}$ e a $4 .^{\text {a }}$, é mais um indicador da negação do acesso à educação nos períodos anteriores ao aqui descrito ou como um indicador de um problema de progressão dentro do sistema. 
O Programa das Nações Unidas para o Desenvolvimento (PNUD) (1989), num relatório sobre a educação em Angola, apresenta três fases distintas da evolução dos alunos no sistema, situação esta que demonstra os índices sobre o acesso à educação pelo sistema de educação. Nesse relatório, a primeira fase corresponde ao período 1976/77 a $1979 / 80^{38}$, que se caracteriza pela elevada procura social da educação, acelerando o número de matrículas, fundamentalmente no ensino de base. A segunda fase, que cobre o período 1979/80 a 1984/85, apresentou um decréscimo acentuado da matrícula no ensino de base ${ }^{39}$. Porém, o período de 1984/85 apresenta certa estabilização. No quadro a seguir, são apresentadas essas fases e os números correspondentes.

Tabela 8: Alunos matriculados

\begin{tabular}{|c|c|c|c|}
\cline { 2 - 4 } \multicolumn{1}{c|}{} & Iniciação & I Nível & $\begin{array}{c}\text { Total Ensino } \\
\text { Base Regular }\end{array}$ \\
\hline $\mathbf{1 9 7 6 / 7 7}$ & 361.446 & 592.450 & 1.032 .844 \\
\hline $\mathbf{1 9 7 9 / 8 0}$ & 664.500 & 1.714 .817 & 2.596 .276 \\
\hline $\mathbf{1 9 8 4 / 8 5}$ & 208.459 & 870.410 & 1.220 .210 \\
\hline $\mathbf{1 9 9 0 / 9 1}$ & 164.146 & 990.155 & 1.313 .600 \\
\hline
\end{tabular}

Fonte: PNUD (1992)

Esses dados mostram a evolução dos alunos no sistema, e para o estudo em questão, os mesmos dialogam com as experiências anteriores à independência sobre o atendimento dos cidadãos no sistema de ensino para a efetivação do direito à educação. Mas a comparação entre os dados da população residente confrontada com a população escolarizada mostra que esses índices estão aquém da efetivação do direito à educação, no quesito acesso, pelo menos entre a população coberta pela idade e pelo nível da escolaridade obrigatória.

\footnotetext{
${ }^{38}$ O período do ano letivo é expresso por dois anos civis porque o ano letivo começava em Setembro de um ano e terminava em Maio do ano seguinte.

${ }^{39}$ Não encontramos nos documentos consultados uma explicação sobre a questão. Mas como este período coincide com o da intensificação da guerra civil, podemos associar esta redução à mesma.
} 
Quadro 7: Escolarização de base por idades

\begin{tabular}{|c|c|c|}
\hline Idade/anos & $\begin{array}{c}\text { Taxa população } \\
\text { matriculada (em } \\
\text { milhares) }\end{array}$ & $\begin{array}{c}\text { População residente } \\
\text { estimada (em milhares) }\end{array}$ \\
\hline 5 & 20,2 & $\sim 340$ \\
\hline 6 & 29,7 & $\sim 320$ \\
\hline 7 & 51,1 & $\sim 300$ \\
\hline 8 & 55,4 & $\sim 285$ \\
\hline 9 & 54,2 & $\sim 270$ \\
\hline 10 & 58,2 & $\sim 260$ \\
\hline 11 & 54,2 & $\sim 250$ \\
\hline 12 & 48,7 & $\sim 249$ \\
\hline 13 & 39,2 & $\sim 247$ \\
\hline 14 & 26,7 & $\sim 240$ \\
\hline
\end{tabular}

Fonte: Adaptado de PNUD (1992)

Por esses dados salienta-se o baixo número de crianças nos 6 anos de idade, ano formal de ingresso no sistema de educação. Este ingresso tardio tornou-se numa das características do sistema. Por exemplo, segundo o PNUD (1992), dos 266 mil alunos que no ano letivo 1990/1991 ingressaram na primeira classe, somente cerca de $20 \%$ o fizeram com 6 anos de idade. Este fator, se adicionado ao da repetência ou, então, dos evadidos que retornam à escola, cria no sistema um desajustamento entre a idade e as classes normais de frequência.

Para uma melhor ilustração da questão da progressão e do acesso tardio, recorremos aos dados de Prata (2000), Quadro 8, apesar de os dados não nos mostrarem as percentagens em função da entrada tardia ou da progressão no sistema. Contudo, os dados elucidam-nos sobre a relação idade, classe de frequência e como estes fatores situam-se na escala de progressão dentro do sistema. Quanto à classe de entrada, notamos que crianças com 10 anos, que por regra deveriam ter concluído o ensino primário, 50\% delas frequentam ainda a primeira classe. Nota-se também a consequente redução acentuada dos efetivos no sistema. As mesmas crianças de 10 anos representam apenas $3,92 \%$ dos efetivos na classe ideal (4. ${ }^{\text {a }}$ classe). Se para os 7 e 8 anos pode existir o 
consolo de serem idades próximas à de entrada, os 10 anos mostram o não cumprimento dos propósitos de escolarização para o ensino primário, particularmente no quesito atendimento.

Quadro 8: Percentagem da População escolar de 5-18 anos sobre a situação escolar, idade e nível de frequência em Angola, 1996

\begin{tabular}{|c|c|c|c|c|c|c|c|c|c|c|c|c|}
\hline \multirow[b]{2}{*}{ Âgc } & \multicolumn{9}{|c|}{ Classe } & \multirow[b]{2}{*}{$\begin{array}{c}\text { Scolarisé } \\
\text { en } 1996\end{array}$} & \multirow[b]{2}{*}{$\begin{array}{l}\text { Jamais } \\
\text { scolarisé }\end{array}$} & \multirow[b]{2}{*}{ Effectifs } \\
\hline & $\begin{array}{c}1^{\text {ire }} \\
\text { année }\end{array}$ & $\begin{array}{c}2^{\text {¿me }} \\
\text { année }\end{array}$ & $\begin{array}{c}3^{\text {eme }} \\
\text { année }\end{array}$ & $\begin{array}{c}4^{\text {eme }} \\
\text { année }\end{array}$ & $\begin{array}{c}5^{\text {ìme }} \\
\text { année }\end{array}$ & \begin{tabular}{|}
$6^{\text {ème }}$ \\
année
\end{tabular} & $\begin{array}{c}7^{\text {ime }} \\
\text { année }\end{array}$ & $\begin{array}{c}8^{\text {ime }} \\
\text { année }\end{array}$ & $\begin{array}{c}9^{\text {eme }} \\
\text { année } \\
\text { et }+\end{array}$ & & & \\
\hline 5 & 100,00 & & & & & & & & & 13,21 & 85,29 & 640 \\
\hline 6 & 95,16 & 4,84 & & & & & & & & 32,38 & 65,01 & 747 \\
\hline 7 & 85,40 & 13,87 & 0,73 & & & & & & & 44,19 & 49,03 & 649 \\
\hline 8 & 73,05 & 22,75 & 4,19 & & & & & & & 53,87 & 37,42 & 605 \\
\hline 9 & 61,14 & 25,14 & 12,57 & 1,14 & & & & & & 61,62 & 29,58 & 580 \\
\hline 10 & 50,00 & 33,33 & 11,27 & 3,92 & 1,47 & & & & & 67,55 & 22,19 & 643 \\
\hline 11 & 35,68 & 28,65 & 20,00 & 9,19 & 5,41 & 1,08 & & & & 62,71 & 22,71 & 582 \\
\hline 12 & 31,15 & 27,87 & 22,40 & 12,02 & 3,28 & 2,19 & 1,09 & & & 64,66 & 17,31 & 560 \\
\hline 13 & 17,90 & 28,40 & 21,60 & 16,05 & 10,49 & 4,32 & 1,23 & . & & 65,85 & 13,01 & 485 \\
\hline 14 & 13,33 & 19,33 & 29,33 & 18,00 & 8,00 & 6,67 & 5,33 & & & 68,18 & 9,55 & 427 \\
\hline 15 & 8,70 & 18,26 & 18,26 & 24,35 & 9,57 & 6,96 & 7,83 & 4,35 & 1,74 & 57,50 & 18,00 & 389 \\
\hline 16 & 8,22 & 10,96 & 12,33 & 13,70 & 20,55 & 15,07 & 13,70 & 5,48 & 0,00 & 42,94 & 15,88 & 353 \\
\hline 17 & 3,33 & 11,67 & 11,67 & 15,00 & 16,67 & 13,33 & 15,00 & 6,67 & 6,67 & 34,09 & 17,61 & 355 \\
\hline 18 & 3,92 & 7,84 & 11,76 & 9,80 & 13,73 & 11,76 & 17,65 & 15,69 & 7,84 & 30,18 & 20,71 & 345 \\
\hline Total & 43,83 & 21,53 & 13,83 & 8,42 & 4,97 & 3,06 & 2,68 & 1,15 & 0,53 & 49,71 & 35.05 & 7360 \\
\hline Urbain & 31,75 & 21,55 & 15,37 & 10,53 & 7,25 & 5,32 & 4,67 & 2,42 & 1,12 & 62,00 & 22,80 & 3020 \\
\hline Rural & 56,20 & 22,24 & 12,21 & 5,31 & 2,95 & 0,94 & 0,41 & 0,06 & 0,00 & 39,40 & 43,50 & 4340 \\
\hline
\end{tabular}

Fonte: Prata (2000)

Sobressaem também os dados das crianças jamais escolarizadas, particularmente na faixa entre 6 e 8 anos. Excluímos a idade de 5 anos apesar de a mesma estar referida na tabela por esta idade ter sido considerada como idade da frequência da iniciação e terse passado a tutela deste nível de educação, em meados da década de 80, para o Ministério da Assistência Social, que tutelava as creches e outros centros de assistência de menores.

Essa concentração de aluno desta faixa etária (6-8 anos) mostra o retardo escolar que resulta de uma combinação de fatores dentre os quais Prata (2000) realça a conjuntura do país (guerra e crise económica) e seu impacto no sistema da educação, a interrupção dos estudos devido à migração forçada dos alunos e/ou suas famílias. É de salientar também os índices que afetam a progressão dos efetivos no sistema, cuja 
barreira é a repetência de ano provocada pela reprovação dos alunos. Esse aspecto será abordado no capítulo subsequente.

Retomando a questão do acesso, julgamos essencial que os dados sobre o acesso à educação escolar formal apresentada pelos números de matrículas elucidem também a diferenciação do atendimento causada pela diferença de sexos e a localização geográfica dos utentes. A questão do gênero apresenta a sua importância devido à discriminação das meninas na frequência à escola. Para além dos entraves culturais no fomento desta discriminação, os económicos também agravaram a condição das meninas em relação à educação.

A questão geográfica como barreira na efetivação escolar resulta do desenvolvimento assimétrico fomentado pelas autoridades coloniais. Ao favorecer o desenvolvimento de infraestruturas escolares nas zonas de concentração da população de origem europeia, os prédios escolares foram construídos principalmente nas regiões próximas do litoral e nos centros urbanos em algumas regiões do interior. Por norma, a população nativa não residia nestas regiões, estando praticamente o grosso concentrado nas zonas rurais. Mesmo com o advento da independência, a maior parte que emigrou para as cidades concentrou-se nas regiões peri-urbanas e nos subúrbios das principais cidades, áreas também nem sempre cobertas por infraestruturas educacionais.

Quanto ao gênero, Prata (2000) mostra que, numa taxa de escolarização para o ensino primário de 53,9\%, os rapazes apresentam uma taxa de 56,6\%; as meninas, 50,1\%. Prata continua, mostrando que com a política da educação equitativa, complementando a educação de massas, a escolarização das meninas progrediu consideravelmente. Como exemplo, a autora toma a população nascida entre 1957-1961 e 1962-1966 que tinha entre 15-19 e 10-14 anos no advento da independência. Nessas gerações, há uma redução da diferença entre gêneros e a frequência da escola para índices inferiores a 15\%. Para as gerações posteriores, dados de 1996 mostram que, da população escolarizada com idades compreendidas entre 5-18 anos, $46 \%$ eram meninas e $53 \%$ rapazes.

Quanto às diferenças regionais, os dados mostram que a oferta da educação expressa na taxa média de escolarização é diferenciada entre as províncias. Apesar de estes dados serem tomados por defeito pelo facto de em muitas delas ter sido difícil reunir 
os dados dada a extensão territorial e a ausência da administração do Estado em muitas partes destes mesmos territórios, eles servem aos propósitos de elaborarem um quadro de análise sobre a frequência da escola distribuído por províncias e também por regiões.

Tabela 9: Taxa de escolarização - Idades (6-14 anos) em 1990/91

\begin{tabular}{|c|c|c|c|}
\hline Províncias & Taxas & Províncias & Taxas \\
\hline Bengo & $66,3 \%$ & Luanda & $69,6 \%$ \\
\hline Benguela & $103 \%$ & Lunda Norte & $41 \%$ \\
\hline Bié & $22,8 \%$ & Lunda Sul & $54 \%$ \\
\hline Cabinda & $87,1 \%$ & Malanje & $21 \%$ \\
\hline Cunene & $62 \%$ & Moxico & $33,8 \%$ \\
\hline Huambo & $23 \%$ & Namibe & $83,5 \%$ \\
\hline Huíla & $60 \%$ & Uíje & $22,8 \%$ \\
\hline Kuando-Kubango & $29,5 \%$ & Zaire & $49 \%$ \\
\hline Kwanza Norte & $39,8 \%$ & República & $45,5 \%$ \\
\hline Kwanza Sul & $49,3 \%$ & & \\
\hline
\end{tabular}

Fonte: PNUD (1992)

Salientam-se como índices mais baixos os apresentados pelas províncias de Malanje (21\%), do Bié $(22,8 \%)$, do Uíge $(22,8 \%)$ e do Huambo (23\%), estando no outro extremo os índices das províncias do Bengo (66,3\%), de Luanda (69,6\%), do Namibe $(83,5 \%)$, de Cabinda $(87,1 \%)$ e de Benguela (103,3\%). Quanto aos dados de Benguela, o PNUD (1992) explica que por serem superiores a 100\% (o que por definição é impossível), os mesmos devem resultar de erros estatísticos causados pela subavaliação da população residente ou pela não contabilização dos fluxos migratórios internos.

Se agrupadas as províncias por regiões geográficas ou, então, na oposição rural versus urbano, o fator desenvolvimento, o nível de destruição causado pela guerra e a intensidade da mesma impactam na taxa de escolarização. Prata (2000), ao abordar a taxa de escolarização (5-18 anos) por regiões, mostra que as províncias com taxas de escolarização que se encontram na região Centro-Sul - Huambo, Bié, Kuando-Kubango $(44,1)$ - são realmente as mais afetadas pela guerra, dentro das quais algumas aldeias e 
vilas foram densamente destruídas pela guerra. $\mathrm{Na}$ região Leste - Lundas e Moxico $(33,6 \%)$-, apesar dos abundantes recursos minerais, com realce para os diamantes, são as províncias menos urbanizadas e com baixos índices de desenvolvimento em comparação com a Capital Luanda (58\%) e as províncias da região Oeste $(54,5 \%)$. A região Norte Uíge, Zaire, Malanje (43,2\%) - também afetadas pela guerra são, por regra, servidas por escolas localizadas nos centros urbanos, principalmente nas cidades capitais. Na relação regiões urbanas versus regiões rurais, o total da taxa de escolarização nas regiões urbanas é de $62,0 \%$, enquanto o das rurais é de $39,4 \%$.

Tabela 10: Taxa de escolarização (5-18 anos) por regiões em 1996

\begin{tabular}{|c|c|}
\hline Regiões & Total (\%) \\
\hline Capital & 58,8 \\
\hline Norte & 43,2 \\
\hline Este & 33,6 \\
\hline Oeste & 54,5 \\
\hline Sul & 52,2 \\
\hline Centro-Sul & 44,1 \\
\hline \multicolumn{2}{|c|}{} \\
\hline Urbano & 62,0 \\
\hline Rural & 39,4 \\
\hline
\end{tabular}

Fonte: Prata (2000)

\subsubsection{A progressão no sistema}

A questão dos baixos índices de progressão dos alunos no sistema em Angola é tida como um dos fatores concorrentes à ideia da baixa qualidade do ensino no país, particularmente quando se refere à qualidade no plano da eficiência e eficácia interna. A repetência escolar, com taxas superiores a 50\%, constitui-se num fator a considerar no quesito dos baixos níveis de rendimento do sistema ou então da eficácia interna do sistema, por isso, "importantes fatores bloqueadores da expansão e desenvolvimento do sistema educativo" (PNUD, 1992, p. 35). 
Tabela 11: Taxas nacionais agregadas de promoção, repetência e abandono (1989-90)

\begin{tabular}{|c|c|c|c|}
\hline Classes & $\begin{array}{c}\text { Taxa de } \\
\text { Promoção }\end{array}$ & $\begin{array}{c}\text { Taxa de } \\
\text { Repetência }\end{array}$ & $\begin{array}{c}\text { Taxa de } \\
\text { Abandono }\end{array}$ \\
\hline 1 . $^{\mathrm{a}}$ & 45,1 & 28,7 & 26,2 \\
\hline $2 .^{\mathrm{a}}$ & 45,3 & 32,0 & 22,7 \\
\hline $3 .^{\mathrm{a}}$ & 49,7 & 28,7 & 21,6 \\
\hline $4 .^{\mathrm{a}}$ & 52,9 & 24,1 & 23,0 \\
\hline $5 .^{\mathrm{a}}$ & 47,5 & 34,2 & 18,3 \\
\hline $6 .^{\mathrm{a}}$ & 42,5 & 34,3 & 23,2 \\
\hline $7 .^{\mathrm{a}}$ & 44,4 & 30,4 & 24,2 \\
\hline $8 .^{\mathrm{a}}$ & 39,6 & 29,4 & 31,0 \\
\hline
\end{tabular}

Fonte: Angola (1993)

É de acrescer a estes dados a informação, ainda segundo a fonte acima referenciada, de que apenas $35 \%$ dos alunos no ensino primário o completam sem qualquer repetição, enquanto $50 \%$ o repetem, pelo menos uma vez. Do total da população matriculada, somente 153/1000 atingem a $6 .^{\mathrm{a}}$ classe.

Percebe-se as elevadas taxas de repetência e abandono e como elas, com certeza, se constituem num obstáculo à efetivação do direito à educação e também num desafio na formulação de políticas de educação que concorram para a efetivação do direito à educação, efetivação esta que não se deve esgotar no acesso à educação escolar formal por reconhecermos a sua importância como um dos primeiros fatores do direito à educação.

O insucesso escolar nas políticas educativas é essencialmente abordado em três perspectivas, nomeadamente, a economicista, a dos direitos, e a pedagógica. No caso particular de Angola, o insucesso escolar é praticamente e só abordado na perspectiva economicista devido aos discursos e às agendas de governo apresentadas pelo governo e seus parceiros. O PNUD, neste relatório que vimos citando, destaca que:

[...] taxas de repetência e de abandono elevadas são sinónimo de desperdícios de recursos, e da permanência de jovens na escola, para além do tempo e com idades superiores ao desejável, ocupando espaços, professores e outros recursos educativos necessários para acolher anualmente os que procuram ingressar de novo no sistema (PNUD, 1992, p. 36). 
É essencialmente o mesmo discurso que vai fundamentar o discurso da progressão continuada como proposta de atendimento na escola na política de educação proposta em 2001, política esta que iremos abordar no capítulo subsequente. Tem sido difícil identificar a abordagem do governo, no período em análise como na atualidade, que apontam a questão do atendimento da escola como condição essencial nas demandas da efetivação do direito à educação, por outras palavras, em que medida a satisfação do direito à educação é o esteio da política da educação do governo?

Quanto à abordagem pedagógica, devido à escassez da produção local sobre a questão, recorremos à produção internacional sobre a questão, dando destaque à discussão que se faz no Brasil devido, por um lado, à nossa inserção nesta realidade académica e, principalmente, devido à forte influência exercida pelos consultores brasileiros, representando quer os parceiros quer o próprio governo, na formulação da política da educação.

Na perspectiva do trabalho pedagógico, a reprovação resulta de uma construção social incorporada na escola com a massificação da educação. Esta levou para a escola uma nova natureza de utentes que devido a vários fatores não se ajustaram às exigências e aos objetivos pré e unilateralmente definidos sobre o que representava o aprendizado. Então, esses grupos, ao não reproduzirem nos moldes esperados o conteúdo passado pela escola, eram necessariamente catalogados de inaptos. Esse desajuste era derivado principalmente da língua de instrução que não era do domínio dos alunos e em muitos casos dos próprios professores, bem como da inaptidão desta educação em relacionar o conteúdo da educação à realidade dos educandos. Essa inaptidão implicava a reprovação e a consequente repetição da classe e os respectivos conteúdos na esperança de que o aluno os dominasse. Mas, Alavarse (2009) questiona sobre o benefício da reprovação dos alunos que a experimentam por ela não garantir nos marcos da pedagogia a almejada recuperação ou o incremento cognitivo. Por isso, a reprovação está mais para malefícios do que benefícios devido às "condições materiais precárias que se somam às crenças de seletividade e de punição que cercam os alunos submetidos a tais práticas" (ALAVARSE, 2009, p. 41). 
É dessa maneira que a escola, na sua missão educadora e na condição de reprodutora de ideologias, busca mais o ajustamento da sua ação na lógica socialmente construída sobre a inaptidão de alguns grupos serem bem-sucedidos na escola do que na promoção do atendimento adequado das várias matrizes que compõem os utentes da escola e, como fim último, permitir que esses cidadãos beneficiem e usufruam efetivamente do direito à educação.

Por a escola não existir num vácuo, ela é profundamente influenciada pelos processos da vida social (ANSALONE, 2009), o que facilitou a implantação na escola, e na sociedade como um todo, a crença que concebe a reprovação como um benefício para quem a ela é submetida, apesar das evidências que a tornam um dos fatores que alimentam a seleção e a eliminação dos ativos escolares no sistema. Jacomini (2010) documenta esse discurso num estudo sobre a opinião dos pais e dos alunos sobre a progressão continuada e a reprovação escolar. Nesse estudo, segundo a autora, a reprovação justifica-se pelo facto de muitos alunos não demonstrarem o aprendizado adequado dos conteúdos escolares submetidos numa determinada série.

No imaginário de muitos pais e alunos, a reprovação aparece diretamente vinculada a uma segunda e "garantida" oportunidade de aprender. Acreditam também que a reprovação é uma medida importante para pressionar os alunos a estudar, contribuindo para a aprendizagem (JACOMINI, 2010, p. 899).

A visão acima descrita é geralmente a mesma que nutre as crenças dos utentes da escola em Angola. Ao aceitarem a reprovação, nota-se a transferência automática da responsabilidade do aprendizado ao aluno, ou então para os pais e alunos, quando esse discurso vem dos professores. Esse pensamento historicamente construído apresenta a reprovação como um fator intrínseco ao processo de ensino e aprendizagem, e não como uma construção de uma determinada ordem social. Complexo se torna ainda, quando nas práticas tradicionais africanas a reprovação não faz nem parte do imaginário, nem da realidade. Aos serem submetidos a várias experiências educativas, os membros da sociedade eram integrados e lhes eram atribuídas tarefas em função de sua habilidade e aptidão. O modelo de educação permitia que as aptidões reveladas definissem a integração tida sempre como mérito e não como alternativa devido a alguma inaptidão. Com a chegada dos colonos europeus e o seu modelo de educação, e com todos os 
equívocos e atos alienadores a eles atribuídos, a reprovação, significando aptidão e inaptidão dos alunos (quando deveria ser a inaptidão do próprio sistema), foi inserida na construção social do progresso de ensino e aprendizagem.

Alimentada pela sua natureza autoritária, a ideia e prática da reprovação, ao longo da história da educação em Angola, desviou a atenção aos reais problemas que condicionavam o aprendizado dos alunos. Nesse período em análise, os cultores e reprodutores do discurso a favor da reprovação eram acometidos por uma amnésia e também um cinismo que não os permitia sequer questionar as condições materiais e pedagógicas criadas para que a educação se efetivasse. Essa "naturalização" do absurdo que é a reprovação fez com que a escola, se reivindicada a educação como um direito, não se ajustasse para corresponder às exigências do paradigma segundo o qual a educação é um direito, logo, é sua missão proporcionar esse direito, bem como a sua universalização e obrigatoriedade.

Portanto, a condenação da reprovação e os mecanismos alternativos à sua presença no sistema de ensino devem particularmente buscar proposições que visem a consumação da educação como um direito. A reprovação é um obstáculo à efetivação desse direito, e é isso que ela representa no processo de ensino e aprendizagem. Ela transforma a educação num privilégio, por um lado, e por outro propicia a exclusão que não se limita à realidade escolar, mas também como uma marca social, uma vez que a escolarização é condição de inserção social, definição de status e definição de papeis na cadeia de produção. Qualquer outra lógica que não se oponha a esta, como a advogada necessidade de optimização dos recursos empregados para a efetivação dos resultados do sistema de educação, é contraproducente na universalização e democratização da educação em Angola, assente fundamentalmente, não apenas no acesso, mas também nas condições de atendimento uma vez integrados no sistema.

\subsubsection{Os professores e as condições de trabalho}

A quantidade e a qualidade dos professores para servirem o sistema de educação em Angola, com o advento da independência, constituíram-se também num enorme desafio para as autoridades do país. Durante o período colonial, a maior parte dos 
professores com qualificações adequadas, como os anos de escolaridade e formação no magistério, era de origem europeia e concentrava-se nos principais centros urbanos. Os nativos eram, em regra, professores para as escolas "indígenas", possuindo apenas a 4. classe como grau de escolaridade e formação pedagógica adequada à escola rural, formação esta que não munia os professores nativos com necessárias competências, conhecimentos e experiências para a condução de um processo de ensino e aprendizagem que promovesse o aprendizado efetivo dos alunos a eles submetidos. O cenário é agravado, primeiro, pela transição política do país, que provocou a saída de Angola de milhares de cidadãos de origem europeia que serviam no sistema de educação; depois, pelas diferenças políticas entre os três movimentos de libertação, que provocaram a saída de Angola, de uns, e do não regresso a Angola, de outros, de cidadãos com qualificações para servirem, não apenas no sistema de educação, mas no sistema administrativo do Estado em geral.

Aquando da reforma de 1978, as autoridades educativas na época anunciaram que tinham apenas 25 mil professores para servirem no ensino primário, concentrados maioritariamente nos centros urbanos. Nesse universo, ainda segundo essas autoridades, $52 \%$ dos mesmos tinham apenas a $4 .^{\text {a }}$ classe como habilitações. Acreditamos também que estes mesmos não eram detentores de qualificações pedagógicas para o exercício do magistério. Já dados de 1992 descrevem a seguinte realidade, por meio de dados de uma amostra de 9 províncias (das 18 existentes) sobre professores a servirem no ensino primário: $7 \%$ dos professores tinham a 4. ${ }^{\mathrm{a}}$ classe; $59 \%$, a 6. ${ }^{\mathrm{a}}$ classe; $26 \%$, a 8. ${ }^{\mathrm{a}}$ classe. Se somadas as percentagens, vemos que $65 \%$ não têm habilitações superiores à $6 .{ }^{\mathrm{a}}$ classe e sem a adequada formação pedagógica conferida no ensino médio (9. ${ }^{\mathrm{a}}$-12. ${ }^{\mathrm{a}}$ classes), em oposição aos regulamentos que exigiam o mínimo a 6 . $^{\mathrm{a}}$ classe.

Nos princípios de base para a reformulação do sistema de educação definido pelo Congresso do MPLA de 1977 inclui-se também a formação de professores. Defende-se que a formação de professores era decisiva para a reformulação do sistema de educação. Para o efeito, os professores deveriam ser

[...] formados dentro da ideologia marxista-leninista. Os professores [teriam] a de entender perfeitamente o que é a educação socialista, coletiva e livre, pra que [pudessem] aplica-la na prática. Os professores [teriam] de estar 
conscientes do papel da vanguarda a que são destinados, como promotores da criação dum HOMEM NOVO, como ativistas da transformação, ao nível de superestrutura das relações sociais (ANGOLA, 1977, p. 76, grifo do autor).

O papel social do professor para o contexto exigia que ele, o professor, fosse considerado

[...] não apenas um mestre que ensina a ler e a escrever. É, antes de tudo, um quadro político que deve dinamizar todas as iniciativas positivas da comunidade em que está inserido, quer sejam políticas, económicas, sociais e culturais. O professor do novo tipo é um ativista que faz as massas anteverem a nova sociedade que elas irão construir (ANGOLA, 1977, p.76).

A formação desses professores respeitaria duas etapas. A etapa normal seria a implantação de institutos de educação de nível médio para a formação de professores para servirem no ensino de base, lecionando essencialmente nas 4 primeiras classes, para além dos institutos superiores de educação. Com a perspectiva de curto e médio prazo, pensouse os Cursos de formação acelerada, os Cursos de superação permanente e os Cursos de Requalificação. Os cursos de formação acelerada destinavam-se a formação de professores para as primeiras 4 classes do ensino de base. Os mesmos cursos teriam a duração de 20 semanas e os candidatos deveriam ter com habilitações literárias a 6 classe. Por sua vez, os cursos de superação permanente destinavam-se a habilitar os antigos monitores escolares, professores de posto, os professores primários eventuais e os professores do ensino secundário do sistema colonial. E os cursos de requalificação destinavam-se a elevar o político e pedagógico dos professores primários diplomados, habilitando-os para lecionarem as 4 primeiras classes do ensino de base e outras (uma ou duas) disciplinas das últimas 4 classes desse nível de ensino.

Outro fator que influencia a qualidade do trabalho desenvolvido pelos professores são as condições das escolas nas quais desenvolvem este trabalho. A maior parte das escolas existentes neste período estava degradada devido, por um lado, à falta de fundos para a sua reabilitação e, por outro, à intensa utilização dos espaços escolares. A intensa utilização é devido à existência de três turnos que funcionavam na escola. Essa intensa utilização para além do desgaste da estrutura e do equipamento das salas de aulas reduziu consideravelmente o número médio de horas de aulas de 4,5 horas para 2,5 horas por dia (ANGOLA, 2004c, p. 32). 
Quadro 9: Perfil dos professores (ensino de base) como definido pelo MED

1. Conhecimento exato das políticas nacionais para o desenvolvimento e a política educativa.

2. Conhecimento profundo dos conteúdos de estudo os nível do ensino pré-escolar e do de base.

3. Conhecimento exato da psicologia geral e da infância a fim de dominar com rigor a capacidade de observar e descrever os fenômenos da vida e do trabalho pedagógico.

4. Conhecimento prático do marxismo-leninismo a fim de permitirem a análise das contradições inerentes aos processos de ensino face ao contexto global da vida social.

5. Consciência de inovação educativa: espirito militante e de iniciativa. Capacidade de organização das atividades extraescolares, do contato com as organizações políticas e sociais do país.

6. Saber preparar corretamente as suas lições, sabe-las dirigir, saber comunicar-se, saber usar o quadro.

7. Saber dirigir reuniões pedagógicas, saber redigir os relatórios das reuniões, saber redigir os relatórios das atividades escolares.

8. Conhecer os regulamentos administrativos.

9. Conhecer as técnicas de avaliação (linguagem precisa e simples, questões claras, precisas etc...).

10. Capacidade de participar no desenvolvimento da comunidade.

Fonte: Angola (1979)

De modo geral, a educação na Primeira República como um direito a efetivar sujeitou-se ao modelo de Estado instituído consequentemente aos princípios regentes deste Estado. Mas, observou-se o "natural" desfasamento entre as proposições para a educação pensada e a efetivação dos objetivos perseguidos. Se contrastada com as expectativas dos inputs do sistema conducentes à garantia do direito, constata-se que a educação oferecida não era completamente fiel a essas expectativas. 


\section{O DIREITO À EDUCAÇÃo NA POLÍTICA EDUCACIONAL NA SEGUNDA REPÚBLICA (1992-2012)}

Em 1992 consolida-se formalmente o Estado democrático de direito inaugurado com a lei constitucional ${ }^{40}$ do ano anterior, e também a Segunda República em Angola. A Lei Constitucional de 1992, Lei 23/92, (ANGOLA, 1992) justificou-se por buscar a revisão da organização do Estado para um democrático de direito. Dá a conhecer que a adopção dessa organização deve-se a implantação da democracia pluripartidária, dos princípios dos Acordos de Bicesse e da perspectiva da realização das primeiras eleições gerais multipartidária, assente no sufrágio universal direto e secreto para a escolha do Presidente da República e de deputados do Parlamento a constituir.

Nessa razão, a lei introduz, genericamente, as seguintes alterações principais:

- altera a designação do Estado para República de Angola, do órgão legislativo para Assembleia Nacional e retira a designação "Popular" da denominação dos Tribunais;

- sobre direitos e deveres fundamentais, introduz alguns novos artigos visando o reforço do reconhecimento e garantias dos direitos e liberdades fundamentais, com base nos principais tratados internacionais sobre direitos humanos à que Angola havia aderido;

- sobre os órgãos do Estado é a definição de Angola como Estado democrático de direito, assente num modelo de organização do Estado baseado na separação de funções e interdependências dos órgãos de soberania e num sistema político semipresidencialista ${ }^{41}$ que reserva ao presidente da República um papel ativo e atuante. Introduzem-se de igual modo e no mesmo sentido, substanciais alterações

\footnotetext{
${ }^{40} \mathrm{Em} 1991$ foi efetuada uma revisão constitucional (Lei 12/91) que se destinou principalmente à criação das premissas constitucionais necessárias a implementação da democracia multipartidária, a ampliação do reconhecimento e garantias dos direitos e liberdades fundamentais dos cidadãos (Lei 23/92 (ANGOLA, 1992)).

${ }^{41}$ No sistema semipresidencialista, há a concentração do poder executivo no Presidente da República e a "aparente" ausência da responsabilidade política do governo perante o Parlamento. O presidente eleito partilha com um primeiro ministro e o seu gabinete a responsabilidade do governo. O presidente da república é o chefe do Estado, eleito pelo voto direito do povo; e o primeiro-ministro é o chefe de governo, nomeado pelo presidente da república e aprovado pela maioria do parlamento. Aqui o chefe de Estado acumula as funções formais que teria num sistema de Parlamentarismo puro e lhe são atribuídos alguns poderes como nomear o primeiro ministro, dissolver o parlamento, propor projetos de lei, conduzir a política externa, exercer o comando das forças armadas, convocar referendum, etc.
} 
na parte respeitante à administração da justiça, à organização judiciária e definemse os contornos essenciais do estatuto constitucional dos magistrados judiciais e do Ministério Público.

Como fundamentos da República de Angola, entre outros, inscreveram-se a dignidade da pessoa humana, o pluralismo de expressão e de organização política e o respeito e garantias dos direitos e liberdades fundamentais do homem, quer como indivíduo, quer como membro de grupos sociais organizados (artigo 2). Esse fundamento dá abertura para o surgimento de novos partidos políticos e o regresso, na arena política de Angola, da FNLA e da UNITA que a par do MPLA vão nos primeiros momentos do multipartidarismo em Angola centrar as atenções políticas. Testemunha-se também o surgimento de várias organizações cívicas e da mídia independente constituída essencialmente por jornais semanários. Ainda no quesito dos direitos, pronuncia-se que as normas constitucionais e legais relativas aos direitos fundamentais devem ser interpretadas e integradas de harmonia com a Declaração Universal dos Direitos do Homem, da Carta Africana dos Direitos dos Homens e dos Povos e dos demais instrumentos internacionais de que Angola é parte.

A soberania é formalmente "devolvida" ao povo que passa a exercer o poder político de modo representativo através da escolha dos seus representantes pelo sufrágio universal periódico, de referendo e outras formas de participação democrática dos cidadãos na vida política da nação.

É nesse contexto formal que são realizadas as primeiras eleições presidenciais e legislativas, em setembro de 1992. Realizadas num clima de tensão política entre os principais contendores políticos, MPLA e UNITA, as eleições presidenciais, na ausência de um vencedor com a maioria definida por lei, ditaram uma segunda entre os candidatos (pela ordem do mais votado) José Eduardo dos Santos (MPLA) e Jonas Malheiro Savimbi (UNITA). Nas legislativas houve a vitória do MPLA, com 129 lugares, seguido da UNITA, com 70 deputados, do Partido de Renovação Social (PRS), com 6 assentos, da FNLA, com 5, do Partido Liberal Democrático (PLD), com 3 e de sete outros partidos, com um deputado cada. 
Esses resultados não foram aceitos pela UNITA, que alegou fraudes significativas no processo. Mas as Nações Unidas, segundo Almeida (2011), em declaração pública considerou as eleições livres e justas apesar de algumas irregularidades que atribuíram à inexperiência dos eleitores e dos legisladores angolanos; segundo a ONU, essas irregularidades não beneficiaram nem prejudicaram diretamente um só partido ou determinado conjunto de partido. Quebra-se então a paz e retoma a guerra, sendo que cada ator da guerra (MPLA vs UNITA) na sua zona de influência militar ocupa o território e assassinam aqueles que eram identificados como opositores. A UNITA perde, em Luanda, nessa condição militante seus relevantes como o seu vice-presidente e o principal interlocutor com o governo nas negociações para a implementação dos acordos de paz. O povo torna-se a principal vítima da guerra eleitoral, uma vez que a mesma, ao contrário da que aconteceu até 1991, passa a ser feita nos principais centros urbanos (capitais de província) e com a característica de guerra convencional, com as tropas do governo sob comando do MPLA a usarem aviões de guerra e as da UNITA a usarem mísseis de longo alcance. Devido a esse desfecho contrário ao esperado para uma disputada que se pretendia democrática nos marcos de um Estado democrático de direito, Almeida (2011) considera que

[...] as primeiras eleições multipartidárias, realizadas a 29 e 30 de Setembro de 1992, mostraram quanto tinha sido precipitada a sua realização porque não se tivera em conta, aqueles que deveriam ter sido os principais beneficiários diretos da independência e do desenvolvimento que se pretendia alcançar, o Povo [...] O destino do País passou a depender de dois oponentes que eram mais inimigos que atores de uma nova era de democracia. (p. 81).

Diante dessa situação, José Eduardo dos Santos, mesmo sem a realização da segunda volta das presidenciais, manteve-se presidente, com o MPLA a formar governo, e assumiu as gestões política, econômica e diplomática do país. No campo diplomático, assegurou o apoio dos Estados Unidos da América, na administração Clinton, que, depois de 17 anos de independência, reconheceu o governo de Angola. Reorganizou e reequipou o exército e conseguiu apoios de velhos e novos aliados para a defesa das instituições nacionais. Nesse momento, a UNITA, sem os antigos aliados, não sustentou a guerra 
convencional e sentiu-se forçada a participar de uma solução negociada, sendo que desta vez negociou os Acordos de Lusaka, de novembro de $1994^{42}$.

Os Acordos de Lusaka justificavam-se pela:

- necessidade da conclusão da implementação dos "Acordos de Paz para Angola", assinados em Lisboa, a 31 de maio de 1991;

- necessidade de um funcionamento regular e normal das instituições resultantes das eleições realizadas nos dias 29 e 30 de setembro de 1992;

- necessidade da instauração de uma paz justa e duradoura no quadro de uma verdadeira e sincera reconciliação nacional;

- pertinentes resoluções do Conselho de Segurança da ONU.

Apesar da não cedência da UNITA, porque "não acolheram com satisfação os resultados das negociações" (ALMEIDA, 2011, p. 84), é empossado em Luanda pelo Presidente da República o governo de Unidade e Reconciliação Nacional (GURN) ${ }^{43}$, tendo com isso a UNITA integrado vários ministérios e ocupado os 70 lugares na Assembleia, vagos desde a interrupção do processo eleitoral. Esses esforços e as subsequentes ações militares do governo, e também as resoluções das Nações Unidas, como a Resolução n. 1.295 , de 18 de abril de 2000 do Conselho de Segurança ${ }^{44}$, não resolvem a guerra. Solução esta que acontece em fevereiro de 2002, quando as tropas do

\footnotetext{
${ }^{42}$ No dia 20 de novembro de 1994, e após difíceis meses de negociações, o então ministro das Relações Exteriores de Angola, Venâncio de Moura, e o, na altura Secretário-geral da Unita, Eugenio Manuvakola, assinaram o Protocolo Adicional de Lusaka, Zâmbia, que recuperava os pontos básicos do Acordo de Bicesse. Segundo Certos sectores, o Protocolo foi rubricado sob pressão dos observadores da troika e do representante especial do Secretário-geral da ONU, o Senhor Alioune Blondin Beye (ALMEIDA, 2011, p.84).

${ }^{43}$ Em 1 de Setembro de 1998 o Governo de Angola suspendeu todos os ministros da Unita e deputados no Governo de Unidade e Reconciliação Nacional e apoiou a criação de um movimento chamado UnitaRenovada, com base em que alguns dos apoiantes da Unita, entre eles Eugenio Manuvakola, não apoiavam a estratégia militarista de Jonas Savimbi (Eugenio, 2011, p.85)

${ }^{44}$ Estas sanções impuseram um bloqueio ao fornecimento de combustível, armamento, assistência técnica e a presença de mercenários às áreas sob o controlo da Unita, e a proibição da compra dos diamantes comercializados pela mesma. Também reafirma-se a necessidade do cumprimento das sanções anteriores 864 (1993), 1127 (1997), 1173 (1998) e 1237 (1999) que restringiam o movimento dos membros da Unita nos territórios dos países membros, e o congelamento dos ativos financeiros em nome desta e de pessoas à ela relacionadas.
} 
governo emboscam e matam em combate Jonas Savimbi, um dos fundadores e presidente da Unita, no Leste de Angola.

Essa realidade permitiu a retomada das negociações de paz que resultaram no "Memorando de entendimento complementar ao protocolo de Lusaka para a Cessação das hostilidades (guerra) e resolução das demais questões militares pendentes nos termos do protocolo de Lusaka" rubricado em 4 de abril ${ }^{45}$ de 2002 no Luena, Moxico, Angola, apesar que, desta vez, o MPLA participou das negociações com larga vantagem militar, e a UNITA, debilitada financeira e militarmente e também sob sanções das Nações Unidas $^{46}$, $\mathrm{O}$ processo de negociação para este memorando contou apenas com a participação das partes em conflitos, sem a tradicional presença da troika (Portugal, Rússia e os Estados Unidos) e das Nações Unidas. O memorando assentou nos seguintes fundamentos:

1. As partes reafirmam o respeito pelo Estado de direito e pelas instituições democráticas na República de Angola e, nesta conformidade, a observância da Lei Constitucional e demais legislação em vigor na República de Angola.

2. As partes reiteram a aceitação inequívoca da validade dos instrumentos juridico-políticos pertinentes, nomeadamente o Protocolo de Lusaka e as Resoluções Conselho de Segurança das Nações Unidas, relativamente ao processo de paz angolano.

3. As partes reconhecem que o respeito pela democracia em todas as esferas e níveis da vida nacional é essencial à paz e à reconciliação nacional.

Com o termino da guerra, foram criadas condições para a transferência da disputa política nos marcos definidos para um Estado democrático de direito. O governo inicia um programa de reconstrução nacional que privilegia essencialmente a reconstrução de estradas, caminhos de ferro, edifícios públicos e também a construção de vários equipamentos sociais, dentre eles escolas primárias e secundárias. Esse programa é

\footnotetext{
${ }^{45}$ O 4 de abril é desde então celebrado o dia da Paz e da Reconciliação Nacional, feriado nacional.

${ }^{46}$ Impostas em 93/94 por este partido não cumprir com as obrigações e princípios dos acordos de paz, as sanções incluíam a proibição de deslocação ao estrangeiro dos membros da Unita, a circulação dos mesmos nos territórios dos países membros da ONU, o congelamento dos bens deste movimento, e o embargo sobre o comercio de diamantes (principal fonte da renda do Partido).
} 
essencialmente financiado por várias linhas de crédito do governo chinês. $\mathrm{Na}$ arena política, surgem as pressões para a realização de eleições, como em julho de 2005, quando partidos da oposição (8 deles com assento no parlamento) subscreveram uma declaração solicitando a criação do conselho eleitor para que as eleições legislativas e presidenciais tivessem lugar no segundo semestre de 2006. Reivindicaram também a convocação pelo chefe de Estado de um processo de consulta envolvendo todas as forças políticas para se aferir as exigências do processo eleitoral ${ }^{47}$. Essa disputa continua ${ }^{48}$, particularmente, no parlamento onde se discutem a legislação eleitoral ${ }^{49}$.

Em 2007, o presidente da República anuncia que no ano seguinte, 2008, seria o da realização das eleições, uma vez que "terminou o registo (sic) eleitoral [... e] além dos êxitos alcançados internamente, com a consolidação da paz e da reconciliação, a situação política é estável" ${ }^{50}$. Em junho de 2008, o presidente José Eduardo dos Santos convoca formalmente as eleições ${ }^{51}$, com a particularidade de se ter convocado apenas as eleições legislativas. As presidências apontadas depois para 2009 são, no entanto, condicionadas pelo presidente da República à aprovação da nova constituição de Angola, que ele considerou uma prioridade para o MPLA. Ao discursar na reunião do Comitê Central do seu partido, o presidente deu indícios (mais tarde confirmados) sobre a alteração da forma de eleição do presidente da República. Apresenta então dois cenários, sendo o do "sufrágio indireto" e o do "sufrágio direto",

As eleições legislativas aconteceram e o MPLA alcançou uma maioria qualificada nos resultados. Com 81,76\% do total de votos, o MPLA assegurou 191 assentos dos 220 disponíveis. A Unita, ao obter 10,36\%, ficou com 16 assentos, o que representa uma redução de 54 assentos em relação às eleições de 1992. Outros partidos com assento parlamentar foram o PRS, com 8, a FNLA e a Nova Democracia (ND), com 2 assentos, respectivamente.

47 Disponível em: <http://www.portalangop.co.ao/angola/pt_pt/noticias/politica/2004/4/19/Partidosoposicao-exigem-eleicoes-gerais-2005,506f38c4-5ed8-4373-9a8b-236a6dc4a440.html>. Acesso em: 22 mar. 2014.

${ }^{48}$ Disponível em: <http://www.angonoticias.com/Artigos/item/14828>. Acesso em: 22 mar. 2014.

${ }^{49}$ Disponível em: <http://altohama.blogspot.com.br/2008/07/mpla-recua-na-alterao-lei-eleitoral.html

${ }^{50}$ Disponível em: <http://diariodigital.sapo.pt/news.asp?id_news=300082>. Acesso em: 22 mar. 2014.

${ }^{51}$ Disponível em: <http://www.angonoticias.com/Artigos/item/18563>. Acesso em: 22 mar. 2014.

${ }^{52}$ Disponível em: 〈http://www.angonoticias.com/Artigos/item/20513〉. Acesso em: 22 mar. 2014. 
Com essa vantagem parlamentar, acrescida ao controlo absoluto do exército e dos órgãos paramilitares, e também dos principais órgãos de imprensa públicos, o MPLA consolidou a sua imagem e desenvolve a sua agenda unilateral de governo. Este poder absoluto redundou em violações a alguns princípios democráticos, principalmente os relacionados às ações de grupos de pressão locais, de vozes críticas ao governo, e da imprensa privada. O Parlamento foi esvaziado dos seus poderes, como quando António Paulo Kassoma, então presidente do parlamento, exarou um despacho que suspendia "temporariamente" a realização de qualquer ação fiscalizadora das atividades do executivo $^{53}$. A atuação dos partidos políticos perde qualquer capacidade de pressão ao governo e a suas políticas, quer no parlamento como fora dele.

Em função da sua vantagem parlamentar, o MPLA fez aprovar, em 2010, uma constituição, com o abandono da plenária pela UNITA e abstenção do PRS, que não reuniu consenso político entre os vários segmentos sociais, com realce para os partidos políticos, com ou sem assento no Parlamento, e vários atores da sociedade civil. O principal ponto de discórdia foi a forma de eleição do presidente da República, que, do anterior sufrágio direto de candidatos dos partidos ou independentes, passa para a eleição dos cabeças de lista dos partidos políticos, isto é, eleição indireta de um presidente que a mesma constituição confere poderes como o de nomear os juízes de todos os tribunais, o procurador-geral da República, e é o titular do poder executivo, dentre outras funções.

Nas questões relativas aos direitos dos cidadãos, a Constituição da República de Angola (CRA) adopta uma redação mais aproximada dos princípios definidos pelas Cartas da ONU e da União Africana (UA), a qual a própria CRA adopta como princípios orientadores da República. É assim que nas tarefas fundamentais dos Estados são inscritos princípios que dialogam com estes instrumentos internacionais sobre direitos humanos. São, entre outras, tarefas fundamentais do Estado, segundo a CRA (ANGOLA, 2010b):

- Assegurar os direitos, liberdades e garantias fundamentais (alínea $a$ );

\footnotetext{
${ }^{53}$ Disponível em: <http://expresso.sapo.pt/angola-lider-da-unita-indignado-com-suspensao-peloparlamento-de-acao-de-fiscalizacao-do-governo=f603195>. Acesso em: 22 mar. 2014.
} 
- Criar progressivamente as condições necessárias para tornar efetivos os direitos econômicos, sociais e culturais dos cidadãos (alínea $c$ );

- Promover o bem-estar, a solidariedade social e a elevação da qualidade de vida do povo angolano, designadamente dos grupos populacionais mais desfavorecidos (alínea $d$ );

- Promover a erradicação da pobreza (alínea $e$ );

- Promover políticas que permitam tornar universais e gratuitos os cuidados primários da saúde (alínea $f$ );

- Promover políticas que assegurem o acesso universal ao ensino obrigatório gratuito, nos termos definidos por lei (alínea $g$ );

- Promover a igualdade de direitos e de oportunidades entre os angolanos, sem preconceitos de origem, raça, filiação partidária, sexo, cor, idade e quaisquer outras formas de discriminação (alínea $h$ );

- Efetuar investimentos estratégicos, massivos e permanentes no capital humano, com destaque para o desenvolvimento integral das crianças jovens, bem como na educação, na saúde, na economia primária e secundaria e noutros setores estruturantes para o desenvolvimento autossustentável (alínea $i$ );

- Promover a igualdade entre o homem e a mulher (alínea $k$ );

- Defender a democracia, assegurar e incentivar a participação democrática dos cidadãos da sociedade civil na resolução dos problemas nacionais (alínea $l$ ).

Relativo a políticas da educação desta República e a semelhança da sua antecessora, esta brota também num cenário de transição, desta feita de um Estado de partido único e com tendência para uma economia planificada para um sistema multipartidário, visando edificar e consolidar um Estado democrático de direito e a adopção de uma economia de mercado. Outro fator a acentuar na política de educação de 2001 é a razão de a mesma ser resultado de uma rede de relações mais diversificadas e abrangentes. A sua concepção não foi apenas uma ação de um partido-Estado centralizador, mas a ação de vários atores, dentro e fora do Estado. 
Entre esses atores, sobressaem os movimentos sindicais que, com a adopção de um novo modelo de Estado, passaram de organizações partidárias corporativas para grupos de interesse e de representação de categorias profissionais. Aos movimentos sindicais, no caso da educação sobressaiu o Sindicato Nacional dos Professores (SINPROF), deveu-se à inclusão das principais reivindicações dos profissionais da educação na agenda pública. Essas reivindicações focavam essencialmente a necessidade da formação inicial e continua dos professores, a condição salarial, as condições materiais para o exercício do magistério, dentre outras.

As instituições internacionais estão presentes nos processos de elaboração, na implementação e na avaliação das políticas da educação em Angola. Os organismos internacionais como o Banco Mundial, e as Agencias das Nações Unidas, como a Unesco, o Unicef e o PNUD, mencionando apenas estas, foram outros atores que atuaram durante o processo da concepção da política. Esses organismos, ao recorrem aos seus recursos financeiros, uma necessidade concreta para o país em vários momentos da sua historia $^{54}$, e do seu know how, buscaram incluir na agenda pública e institucional os seus programas direcionados à educação, tendo sido essencialmente adoptados no conteúdo da política em vigor os princípios definidos no programa Educação Para Todos, resultante dos compromissos, quer os de Jomtien (1990) como os de Dakar (2000). Na condição de parceiro financiador, o Banco Mundial, por sua vez, tendeu a adequar a política da educação em Angola aos marcos e objetivos do Programa de Redução da Pobreza, no qual a educação é eleita como um dos fatores que concorre para a redução da pobreza e da melhoria da qualidade de vida.

Em outras fases da política, destacam-se as ações para atenuar a carência de quadros que pudessem contribuir na elaboração da programação dos conteúdos e das atividades educativas no sistema de educação, a supervisão da implementação dessas atividades e a formação de formadores para servirem o sistema. Houve também a presença de professores oriundos de países estrangeiros aliados (Cuba, Rússia, Vietnam, etc.) para leccionarem nas escolas angolanas. Mas, não nos deparamos com a atuação dos

\footnotetext{
${ }^{54}$ Em dois momentos distintos, 1992 e 2002, ao decretar tréguas no conflito armado, as autoridades angolanas buscaram, junto das instituições financeiras internacionais e agências das Nações Unidas, fundos destinados a reconstrução do país, particularmente a reabilitação de infraestruturas socioeconômicas.
} 
mesmos nas classes entre 1. ${ }^{\mathrm{a}}$ e $4 .^{\mathrm{a}}$, classes estas cobertas pela obrigatoriedade da educação. O que pressupõe que o ensino primário era de responsabilidade dos professores locais. E se atendermos que estes professores estrangeiros eram, em teoria, melhor capacitados, e se levarmos em consideração que os professores angolanos com piores qualificações eram destinados para o ensino primário, é de crer que a prestação de um serviço de qualidade para os alunos atendidos na escola não era preocupação prática. Mas, supomos igualmente que esta ausência pode ser devido ao pobre domínio da língua portuguesa, manifesto pela maioria dos professores.

Mas a cooperação internacional não se limitava nas relações com os parceiros políticos e ideológicos. Outros organismos internacionais, em particular as agências das Nações Unidas, sempre estiveram presentes no cenário das políticas da educação. No caso concreto da política em estudo, organismos como o Unicef, a Unesco, os países Africanos de Língua Oficial Portuguesa (PALOP) e países da Comunidade dos Países de Língua Portuguesa (CPLP), como Portugal e Brasil, participaram dos estudos setoriais que informaram a reforma educativa de 2001. Durante o processo, principalmente depois de 1991, acentuou-se a adopção na política de educação em Angola dos modelos educativos ocidentais através de programas e projetos propostos por Unesco, União Europeia e CPLP para, como afirma Ngaba (2012), visar a legitimidade internacional na nova ordem mundial. É nessa perspectiva que os "processos de aproximação das políticas educativas desencadeadas nos últimos tempos em Angola têm como centro as políticas educativas da UNESCO, da CPLP e da União Europeia" (NGABA, 2012, p. 207). Para ilustrar melhor estes elementos da constatação, retomamos aqui um quadro comparativo no qual o autor acima referenciado compara as propostas dos marcos de Dakar e os objetivos propostos pela agenda local da educação (Quadro 10).

Contudo, ao se analisar os resultados dos diferentes diagnósticos e estudos feitos ao sistema de educação, constata-se que muitos dos objetos acima apresentados enquadram-se nas demandas anteriores à data da definição dos compromissos de Jomtien (1990) e dos marcos de Dakar (2000), como a universalização do acesso ao ensino primário e a promoção da qualidade na educação oferecida. A relevância da adopção dos mesmos nos contextos de compromissos supranacionais resulta no carácter compulsório da sua observação. Mas, a necessidade de observar os compromissos da agenda 
internacional pode constituir-se em um obstáculo à satisfação das peculiaridades dos desafios da educação em Angola, apesar da recomendação do ajuste dos programas de ação dos marcos de Dakar às demandas locais, a fim de melhor atenderem e satisfazerem a educação como direito da condição humana. A dinâmica e virtude dos mecanismos de cobrança de resultados induz o governo a conferir maior rigor ao atendimento da agenda internacional em detrimento da demanda interna devido aos fatores de barganha que são amplamente desiguais.

Quadro 10: Comparação entre o novo sistema educativo e os Marcos de Dakar 2000

\begin{tabular}{|c|c|c|}
\hline Cate & Novo Projeto Educativo & Marco de Dakar \\
\hline & $\begin{array}{l}\text { 1. }{ }^{\circ} \text { Expandir e melhorar a proteção e } \\
\text { educação da primeira infância, sobretudo } \\
\text { das mais vulneráveis. } \\
\text { 2. }{ }^{\circ} \text { Assegurar que até } 2015 \text { todas as } \\
\text { crianças, incluindo meninas, de minorias } \\
\text { étnicas tenham acesso ao ensino } \\
\text { primário gratuito, obrigatório e de } \\
\text { qualidade. } \\
\text { 3. }{ }^{\circ} \text { Responder às necessidades de } \\
\text { aprendizagens de todos os jovens e } \\
\text { adultos através de uma aprendizagem } \\
\text { adequada. } \\
\text { 4. }{ }^{\circ} \text { Aumentar em } 50 \% \text { até ao ano } 2015 \text { o } \\
\text { número de adultos alfabetizados, } \\
\text { sobretudo as mulheres. } \\
\text { qualitativos da educação, garantindo } \\
\text { resultados reconhecidos e mensuráveis } \\
\text { (ANGOLA, 2003) }\end{array}$ & $\begin{array}{l}\text { 1. }{ }^{\circ} \text { A expandir e melhorar o cuidado e a } \\
\text { educação da criança pequena, } \\
\text { especialmente das mais vulneráveis e em } \\
\text { maior desvantagem. } \\
\text { 2. } \\
\text { ênfase especial nas meninas e nas crianças } \\
\text { em circunstâncias difíceis e pertencentes a } \\
\text { minorias étnicas, tenham acesso à educação } \\
\text { primária, obrigatória, gratuita e de boa } \\
\text { qualidade até o ano } 2015 \text {. } \\
\text { 3. }{ }^{\circ} \text { Assegurar que as necessidades de } \\
\text { aprendizagem de todos os jovens e adultos } \\
\text { sejam atendidas pelo acesso equitativo à } \\
\text { aprendizagem apropriada e às habilidades } \\
\text { para a vida. } \\
\text { 4. }{ }^{\circ} \text { Alcançar uma melhoria de } 50 \% \text { nos } \\
\text { níveis de alfabetização de adultos até } 2015 \text {, } \\
\text { especialmente para as mulheres e acesso } \\
\text { equitativo à educação básica e continuada } \\
\text { para todos os adultos. } \\
\text { 5. Eliminar disparidades de género na } \\
\text { educação primária e secundaria até } 2005 \text { e } \\
\text { até } 2015 \text { alcançar a igualdade do género, } \\
\text { com enfoque na garantia ao acesso e ao } \\
\text { desempenho pleno e equitativo de meninas } \\
\text { na educação básica de boa qualidade. } \\
\text { 6. }{ }^{\circ} \text { Melhorar todos os aspectos da qualidade } \\
\text { da educação e assegurar excelência para } \\
\text { todos em vista a resultados positivos para } \\
\text { todos. }\end{array}$ \\
\hline
\end{tabular}

Fonte: Ngaba (2012) 
Quanto ao governo como autor, a sua presença é evidente no processo. Para além de materializar os compromissos eleitorais de implementar a educação para todos, as parcerias via protocolos e compromissos com organismos internacionais tendeu a materializar as recomendações de programas seus para a correção das debilidades que a política de ensino concebida e implementada em 1978 demonstrou. A ação do governo na definição da política da educação é demarcada por ações concretas. Essas ações tomam as formas diferenciadas, desde diagnósticos efetuados para sanar as debilidades visíveis sobre a performance do sistema de educação, ao atendimento de demandas concretas como as relacionadas ao acesso e também à qualidade da educação oferecida, bem como à necessidade do saneamento do currículo e dos objetivos da educação da carga ideológica do socialismo de cariz marxista-leninista depois de decretado o Estado democrático de direito e a abertura ao multipartidarismo.

Nesse processo de definição da política, encontramos nas ações de 1983 o diagnóstico do posicionamento institucional do sector educativo. Este diagnóstico deu origem às resoluções 2/83 e 6/83 do Conselho de Ministros ${ }^{55}$ sobre as medidas para se evitar o estrangulamento do sistema educativo (ZAU, 2009). A principal razão para o diagnóstico era a demonstrada capacidade do sistema educativo em satisfazer a demanda do acesso à educação e a melhoria do atendimento aos cidadãos integrados no sistema. Nesse período, a economia do país estava profundamente afetada pela guerra e também pelo colapso da estrutura produtiva devido ao desmantelamento da estrutura económica durante o processo de transição para a independência. A renda do país era essencialmente garantida pela indústria do petróleo e pela assistência dos parceiros do bloco socialista.

Em 1986 é efetuado o "Diagnóstico endógeno do subsistema de base-regular". Feito por técnicos angolanos e cubanos, este resulta de um estudo realizado em cinco províncias (Cabinda, Huambo, Benguela, Huíla e Luanda) num universo de 18 consideradas com amostras mais significativas. Os resultados relataram, quanto aos alunos, a sua condição de pobreza manifesta na ausência ou na precária assistência médico sanitária, a alimentação não adequada e a carência de vestuário. Ainda sobre os

\footnotetext{
${ }^{55}$ Órgão colegial, deliberativo que reúne os ministros e outros membros do governo, sob a presidência do chefe de Estado. Depois das alterações instituídas pela Constituição de 2010, este conselho passa para um órgão de consulta do presidente da República.
} 
alunos, a sua educação escolar formal era afetada também pela falta de professores e de escolas e, também, pela excessiva mobilidade dos alunos durante o ano letivo. Relata-se ainda o elevado número, aproximadamente um milhão, de crianças entre os 6-14 anos não atendidas pelo sistema de educação.

Outrossim, o documento confirma as elevadas taxas do atraso escolar derivadas dos altos índices de reprovação/repetência e do abandono escolar. Esses dados aliavam-se às precárias condições de atendimento para a maioria dos utentes da escola pública, resumidas nos meios de ensinos inadequados, instalações escolares precárias e carências sociais. No trabalho da escola, sobressaíam o não cumprimento dos calendários e dos programas escolares e a não observação das obrigações dos planos de estudo e das modalidades de avaliação. Como refere Zau (2009), "contrariamente às expectativas governamentais, o sistema educativo angolano pouco contribui para a formação de recursos humanos necessários ao desenvolvimento do país” (p. 258). Também, cremos nós, que não reuniu condições para a efetivação do direito à educação que não se esgota na preparação de força de trabalho para o mercado e as necessidades de desenvolvimento definidos nas políticas de governo.

No ano 1987, a Assembleia do Povo ${ }^{56}$ aprovou a resolução 5/87 para a implementação das resoluções 2/83 e 6/83 do Conselho de Ministros, isto é, quatro anos após a tomada das resoluções. Nesse mesmo ano aprovou-se a reformulação do organograma de 1980 do Ministério da Educação e também o Estatuto Orgânico do Ministério da Educação pelo Decreto 9/87. Nesse estatuto realce à decisão de as escolas do $1^{\circ}$ nível do ensino de base regular passarem a depender administrativamente em nível local das delegações provinciais da educação e, metodologicamente, em nível central. Realçamos nesta medida a possibilidade de contratação dos professores e o repasse de verbas às escolas ser atribuída às autoridades ao nível da província.

\footnotetext{
${ }^{56}$ A Assembleia do Povo é o órgão supremo de poder do Estado na República Popular de Angola e exprime a vontade soberana do povo angolano. A Assembleia do Povo promove a realização dos objetivos da RPA definidos pelo MPLA - Partido do Trabalho. O Presidente da Assembleia do Provo é o Presidente da República. (CORREIA e SOUSA, 1996).
} 
Sucessivamente, surge a diretiva n. 9/BP/88 do bureau político ${ }^{57}$ do MPLA sobre as "Medidas para o Saneamento e Estabilização do Sistema de Educação e Ensino e a Constituição das Bases Gerais para um Novo Modelo”. É esse documento que define a essência da política de educação que deveria superar o desfasamento entre os objetivos propostos e os recursos e meios mobilizados para a sua realização, a incapacidade de efetivar o direito à educação (entende-se pela sua declaração a garantia do acesso de todos à escola) e a natureza confusa da regulamentação normativa do sistema e das estruturas e órgãos que o compõem.

Como sequência à diretiva, é elaborado, em 1990, o Projeto de Reformulação do Sistema Educativo e a aprovação dos fundamentos para o novo modelo de sistema de educação. Este provecto constitui os fundamentos para a realização, em 1991, de uma mesa redonda sobre a educação para todos. Ainda neste ano em que realizou essa mesa redonda, o Ministério da Educação definiu o quinquénio 1991-1995 como o da preparação e da reformulação do no novo sistema educativo. Realça-se também a Lei 18/91, que marca o reinício da atividade do ensino privado.

Em 1993 é feito pelo governo e seus parceiros, a Unesco e o Unicef, o exame setorial que buscou as opções para a reconstrução do sistema educativo. Esse exame deu corpo em 1995 do Plano-Quadro Nacional da Reconstrução do Sistema Educativo (19952005) apresentado pelo Ministério da Educação. Mediante esse plano, previa-se a preparação de uma base de consenso nacional sobre o futuro da educação e do papel desta na reconstrução nacional. O plano apresentou propostas de ações para a reconstrução do sistema escolar, a promoção de competências técnicas e profissionais, a reforma do currículo escolar e a reorganização e administração do sistema educativo, tendo em conta os resultados do diagnóstico de 1986 e também o estudo setorial de 1992.

Como corolário da fase de concepção da política, é aprovada e tornada pública, em 2001, a LBSE, Lei 13/01, (ANGOLA, 2001a), que formula o novo sistema de educação e as determinações da política educativa. Definidos os pressupostos da política pelo governo e parceiros, organiza-se sob a égide do Ministério da Educação, em 2004, a

\footnotetext{
${ }^{57}$ Pelos estatutos do MPLA, o bureau político é o organismo permanente de direção do partido que delibera no intervalo das reuniões do Comité Central e se ocupa dos ajustamentos pontuais da estratégia do Partido.
} 
consulta pública sobre o Plano Nacional da Educação para Todos. Este evento é uma pretensão, segundo Ngaba (2012), do Governo angolano e da Unesco, em convencer a população angolana sobre a relevância do Plano Nacional da Educação para Todos, tornando-se assim numa "campanha em busca da legitimidade nacional na implementação da nova reforma educativa" (NGABA, 2012, p. 207). Como uma iniciativa do Ministério da Educação e parceiros com a Unesco, a

[...] consulta pública constitui um espaço alargado de reflexão e debate, reunindo instituições públicas e organizações representativas da sociedade civil, sector privado, agências do sistema das Nações Unidas, parceiros bilaterais e multilaterais de desenvolvimento com o objetivo de se construir um consenso a volta das linhas diretrizes do anteprojeto do Plano de Ação Nacional de Educação para todos com vista a sua posterior aprovação pelos órgãos competentes do governo (ANGOLA, 2004c, p. 2).

Como objetivos, a consulta propôs-se a refletir sobre a implementação dos 6 objetivos do Quadro de Ação de Dakar nas condições concretas da República de Angola: a mobilizar o envolvimento de instituições públicas, privadas, confissões religiosas, sindicais, sócio-profissionais de solidariedade social na implementação do desafio da "Educação Para Todos" em Angola; promover um debate sobre os rumos e desafios da Educação em Angola até 2015 no Quadro de Ação de Dakar e dos Objetivos e Metas de Desenvolvimento do Milénio. (ANGOLA, 2004c). No final dos trabalhos, a consulta produziu constatações e recomendações. Apresentamos no quadro a seguir aquelas que julgamos pertinentes para o estudo.

\section{Quadro 11: Constatações e recomendações da consulta pública}

\begin{tabular}{|c|c|}
\hline Constatações & Recomendações \\
\hline $\begin{array}{l}\text { 1. Insuficiências de recursos financeiros para a } \\
\text { gestão do sistema de ensino; } \\
\text { 2. Falta de incentivos para a retenção e } \\
\text { mobilidade geográfica do corpo docente no } \\
\text { sistema de Educação e Ensino; } \\
\text { 3. Fraco domínio da língua veicular pelos } \\
\text { alunos e a língua nacional pelos professores; } \\
\text { 4. Fraca utilização da língua gestual no Sistema } \\
\text { de Educação e Ensino; } \\
\text { 5. Não utilização das línguas nacionais no } \\
\text { processo de ensino aprendizagem; } \\
\text { 6. Insuficiência de infraestruturas físicas e }\end{array}$ & $\begin{array}{l}\text { 1. Construção e apetrechamento de escolas primárias; } \\
\text { 2. Reforço das capacidades dos centros de formação } \\
\text { local para que possam implementar os diferentes } \\
\text { programas e modalidades de formação de professores, } \\
\text { formadores e gestores escolares; } \\
\text { 3. Que o registo educacional das crianças a partir dos } 5 \\
\text { anos seja feito por brigadas mistas integradas por } \\
\text { agentes da educação e da justiça; } \\
\text { 4. Implementação de políticas de incentivos para a } \\
\text { retenção do corpo docente no sistema de educação e } \\
\text { ensino particularmente nas zonas rurais; } \\
\text { 5. Reforço na aprendizagem da língua portuguesa para }\end{array}$ \\
\hline
\end{tabular}


material escolar. possibilitar a formação integral;

6. Necessidades de melhorar os mecanismos de recolha e tratamento de informação estatística;

7. Garantia de distribuição do material escolar;

8. Criação e apetrechamento de bibliotecas escolares.

\subsection{Legislação e filosofia}

A reforma educativa de 2001 propôs-se a corrigir os desafios produzidos pela implementação da reforma anterior e o ajuste dos fins da educação ao contexto sociopolítico abraçado por Angola na época. Essas distorções resultaram da incapacidade do governo de alargar geograficamente a rede escolar em razão de, por um lado, a escassez de recursos financeiros e de uma política efetiva, por outro lado, pela guerra civil que impedia as ações do governo em algumas regiões do país e que em alguns casos destruíram também os prédios escolares. Acresce-se também a não efetivação do programa de formação de professores que pudessem consumar os objetivos dos fins propostos. Para além da garantia do acesso à educação, também concebeu-se o cenário de melhorar o atendimento dos alunos matriculados pela escola a fim de garantir uma educação com qualidade.

Como fundamento legal, a reforma educativa de 2001, que corporizou a política da educação desse período, legitimou-se pela Lei Constitucional de 1991 e posteriormente, pela Constituição da República de Angola de 2010 (ANGOLA, 2010a). A Lei Constitucional de 1991 inscreveu alterações que se destinaram, principalmente, à criação das premissas constitucionais necessárias à implementação da democracia pluripartidária, à ampliação do reconhecimento e das garantias dos direitos e liberdades fundamentais dos cidadãos, assim como a consagração constitucional dos princípios basilares da economia de mercado.

Nessa lei, quanto ao direito à educação, a RPA continua a reafirmar, por meio do artigo 16, o respeito e a aplicação dos princípios da Carta das Nações Unidas e da Carta 
da Organização da União Africana (OUA). Como inovação, o ponto 3 do artigo 29 convoca a família e reconhece um papel que já lhe é tradicional, o de participar na efetivação do direito à educação. Assim “[à] família com especial colaboração do Estado, compete promover e assegurar a proteção e educação das crianças e dos jovens" (CORREIA e SOUSA, 1996). Ao ser reservada ao Estado "uma colaboração especial", pode se inferir que a competência da efetivação do direito à educação é reservada à família. Para que assim aconteça, esse dever da família goza de garantias do Estado, segundo o artigo 37 da mesma lei: “A República Popular de Angola deve criar as condições políticas, económicas e culturais necessárias para que os cidadãos possam gozar efetivamente dos seus direitos e cumprir integralmente os seus deveres" (CORREIA e SOUSA, 1996).

Outra iniciativa é a nova redação do artigo 36, declarando, neste caso, que o Estado deve promover o acesso de todos à instrução, ao garantir a participação dos diversos agentes particulares na sua efetivação. Percebe-se aqui a abertura do provimento da educação, em todos os níveis, à iniciativa privada e o fim do monopólio do Estado, que vigorou desde 1975 aquando da aprovação da lei da nacionalização do ensino. Apesar de essa abertura ser relevante devido às dificuldades do Estado, como provedor único, em garantir a educação para todos e de satisfazer a demanda, a referida abertura não significa que o Estado deve omitir-se das suas responsabilidades na garantia do direito à educação. A educação provida pelos agentes privados deve ser usufruída com uma escolha pessoal, dentro dos seus privilégios, e não como consequência deliberada do Estado em efetivar o direito à educação como usufruto dos direitos de cidadania. É necessário recordar que a não efetivação do direito pode verificar-se pelo não provimento de vagas para garantir o acesso ou, então, quando as vagas existirem, as condições oferecidas na instituição são perniciosas para a efetivação da educação de facto.

Essas duas perspectivas são fatores presentes, em alguns combinados, e separados em outros casos, no sistema de educação em Angola e têm, os mesmos, ao longo dos anos, se constituído em dois fatores que corrompem a efetivação do direito à educação. Alguns cidadãos para se livrarem desses obstáculos, à garantia da educação dentro dos padrões almejados, socorrem-se das escolas privadas que se propõem a oferecer melhores condições de realização da educação. Porém, como veremos na caracterização do ensino 
particular, muitos dos cidadãos, principalmente os residentes nas regiões peri-urbanas, têm nestas escolas particulares, muitas delas sem condições materiais condignas e professores qualificados para o magistério, como a única possibilidade de acesso à educação. Possibilidade esta que, em muitos casos, não está ao alcance de todos, devido à incapacidade das pessoas dessas áreas (principais focos de pobreza), em arcarem com os custos inerentes aos serviços prestados pelas escolas particulares.

A Lei Constitucional de 1992 (ANGOLA, 1992), no que concerne a direitos e deveres fundamentais, inscreveu novos artigos para reforçar o reconhecimento e as garantias dos direitos e liberdades fundamentais à luz dos principais tratados sobre direitos humanos aos quais Angola aderiu. Manteve-se o princípio segundo o qual o Estado respeita as Cartas da ONU e da OUA (artigo 15). No artigo 29, no ponto 3, reitera-se o dever da família de, em colaboração com o Estado, promover e assegurar a educação integral das crianças e dos jovens. Conservou-se também para o Estado o dever de promover o acesso de todos os cidadãos à instrução e o de garantir a participação de agentes particulares na efetivação desse dever (artigo 49, ponto 9).

Outra questão que o Estado reafirmou é a garantia do provimento da educação como dever do Estado e direito do cidadão. Como obrigação, "[o] Estado deve criar as condições políticas, económicas e culturais necessárias para que os cidadãos possam gozar efetivamente dos seus direitos e cumprir integralmente os seus deveres" (artigo 50) (CORREIA e SOUSA, 1996).

Essa legislação dá continuidade às mudanças necessárias para adequar as leis às mudanças sociais, económicas e políticas que decorriam no país na época. Como efeito da assinatura dos Acordos de Paz, de maio de 1991 - uma tentativa de se pôr termo à guerra civil que assolava o país desde 1975 -, o Estado angolano preparava uma série de reformas para a recuperação do país. Para o direito à educação, o governo de Angola projetou uma reforma do sistema de educação, depois de 1978.

Outro suporte legal para o sustento do direito à educação é a Constituição da República de 2010. Essa constituição, a primeira para Angola como país independente, é o culminar das sucessivas Leis constitucionais $(1975,1991$ e 1992) que vigoraram no país. 
A Constituição de 2010 (ANGOLA, 2010a), como destaca o seu preâmbulo, representa o culminar do processo de transição constitucional iniciado em 1991, com a aprovação pela Assembleia do Povo, da Lei n. ${ }^{\circ} 12 / 91$, que consagrou a democracia multipartidária, as garantias dos direitos e liberdades fundamentais dos cidadãos e o sistema económico de mercado, mudanças aprofundadas pela Lei da Revisão Constitucional n. 23/92 (ANGOLA, 1992). Nessa Constituição, o direito à educação surge logo na determinação das tarefas fundamentais do Estado. No artigo 21, encontramos essas determinações:

g) promover políticas que assegurem o acesso universal ao ensino obrigatório gratuito, nos termos definidos pela lei;

h) efetuar investimentos estratégicos, massivos e permanentes no capital humano, com destaque para o desenvolvimento integral das crianças e dos jovens, bem como na educação, na saúde, na economia primária e secundária e noutros sectores estruturantes para o desenvolvimento autossustentável. (ANGOLA, 2010a).

Constata-se que na alínea $g$, a redação que nas leis anteriores era "promover o acesso" é substituída por "promover políticas que assegurem", o que pode ser interpretado como uma ação revestida de maior concertação e solidez. Essa ideia é reforçada na alínea $h$, ao considerar que a educação não se desenvolve isolada de outros fatores sociais. O carácter transversal do tratamento da educação é um fator determinante para a sua efetivação.

Como direito fundamental universal, o direito à educação é salvaguardado indiretamente no artigo 26, sobre o âmbito dos direitos fundamentais, cujo ponto 2 determina:

Os preceitos constitucionais e legais relativos aos direitos fundamentais devem ser interpretados e integrados de harmonia com a Declaração Universal dos Direitos Humanos, a Carta Africana dos Direitos do Homem e dos Povos e os tratados internacionais sobre a matéria, ratificados pela República de Angola (ANGOLA, 2010a, art. 26. ${ }^{\circ}$ ).

O direito à educação é também, nessa Constituição, definido como direito do cidadão, no ponto 1 do artigo 79. O ensino especial, por sua vez, surge pela primeira vez retratado na Constituição. O artigo 83, reservado aos cidadãos com deficiência, define no ponto 1 que os "cidadãos com deficiências gozam plenamente dos direitos e estão sujeitos 
aos deveres consagrados na Constituição"; no ponto 4: o "Estado fomenta e apoia o ensino especial e a formação técnico-profissional para os cidadãos com deficiência". Realçamos, uma vez mais, que persiste a redação que enuncia a promoção e não a determinação de um dever do Estado a garantia do direito à educação. Essa redação pode induzir a interpretação da não responsabilização legal pela educação como direito, sempre que se verificar a omissão pelo Estado do seu dever de garantir o acesso à educação ou dos direitos a ela correlatos.

Para proteger o direito à educação contra os abusos que possam ser cometidos pelo Estado ou pelos particulares, a Constituição declara-o como direito fundamental (Título II). Essa condição salvaguarda constitucionalmente esse direito e outros que englobam os direitos humanos universais e os direitos nacionais dos cidadãos (NERY JÚNIOR; NERY, 2009).

Para além do acima descrito, estão declarados na Constituição de 2010 os mecanismos para a salvaguarda dos direitos. Como seu princípio fundamental, a República de Angola:

[...] promove e defende os direitos e liberdades fundamentais do Homem, quer como indivíduo, quer como membro de grupos sociais organizados, e assegura o respeito e a garantia da sua efetivação pelos poderes legislativos, executivo e judicial, seus órgãos e instituições, bem como por todas as pessoas singulares e coletivas. (ANGOLA, 2010a, art. $2^{\circ}$ ).

$\mathrm{Na}$ perspectiva legal, dá-se garantia às ações que visem a garantia dos direitos. $\mathrm{O}$ artigo 73, intitulado, “direito de petição, denúncia, reclamação e queixa", consagra o seguinte:

Todos têm o direito de apresentar, individual ou coletivamente, aos órgãos de soberania ou quaisquer autoridades, petições denúncias, reclamações ou queixas, para a defesa dos seus direitos, da Constituição, das leis ou do interesse geral bem como o direito de ser informados em prazo razoável sobre o resultado da respectiva apreciação. (ANGOLA, 2010a).

Para além do postulado no artigo acima citado, reserva-se também ao cidadão o direito de ação popular (Artigo 74):

Qualquer cidadão, individualmente ou através de associações de interesses específicos, tem direito à ação judicial, nos casos e termos estabelecidos por 
lei, que vise anular atos lesivos [...] à qualidade de vida [...] à legalidade dos atos da administração e demais interesses coletivos. (ANGOLA, 2010a).

E para que esta ação judicial se efetive, estabelece-se no artigo 29 que:

A todos é assegurado o acesso ao direito e aos tribunais para a defesa dos seus direitos e interesses legalmente protegidos, não podendo a justiça ser denegada por insuficiência dos meios económicos. (ANGOLA, 2010a, art. 29, ponto 1).

Todos têm direito a que uma causa em que intervenham seja objeto de decisão em prazo razoável e mediante processo equitativo. (ANGOLA, 2010a, art. 29, ponto 4); e

Para a defesa dos direitos, liberdades e garantias pessoais, a lei assegura aos cidadãos procedimentos judiciais caracterizados pela celeridade e prioridade, de modo a obter tutela efetiva e em tempo útil contra ameaças ou violações desses direitos (ANGOLA, 2010a, art. 29, ponto 5).

Nos casos em que a falta de norma reguladora torna inviável o exercício dos direitos e liberdades constitucionais e das prerrogativas inerentes à nacionalidade, à soberania e à cidadania, e nos quais o cidadão tem o seu direito declarado, mas não sabe como exercê-lo, o artigo 232 (inconstitucionalidade por omissão) presta-se a fazer com que, na prática, possa ser exercido o direito previsto na Constituição.

De certa forma, constatamos que as Leis Constitucionais e a Constituição de 2010 cumpriram com a exigência de declarar o direito à educação, declaração esta que foi sendo mais detalhada e atualizada em função da dinâmica sociopolítica do país. Para além da declaração, a Constituição de 2010, em particular, consagrou condições para que os cidadãos, individual ou coletivamente, possam exigir a efetivação desse direito nos marcos do sistema de justiça.

Apesar dessas melhorias na legislação, os obstáculos à efetivação do direito à educação, resultantes da negação desse direito pela ação do poder político e/ou particular, são ainda uma realidade. Os cidadãos, individual ou coletivamente, dificilmente se socorrem da legislação para estabelecer esse direito de obrigarem o poder público a cumprir o seu dever. Qual é a razão da negação dos próprios cidadãos a esses pressupostos da cidadania? O principal fator é a atuação do poder público. As denúncias dos atos do poder público que resultam na violação dos direitos dos cidadãos, regra geral, não recebem o tratamento devido dos órgãos do sistema de justiça. A morosidade e os 
altos custos dos serviços do sistema de justiça previnem os cidadãos de buscarem a solução legal para a garantia do direito reivindicado. Outro fator que sobressai é o próprio cidadão no exercício da cidadania. Verifica-se, na maioria dos cidadãos, a ausência da cultura de recorrer à justiça para a efetivação dos seus direitos, em geral, e os referentes à educação, em particular. Se, por um lado, existe o desconhecimento pela maioria dos cidadãos dessa via; por outro, há a lentidão do sistema de justiça, bem como os custos que comportam os processos judiciais.

Pulqueria Van-Dunén Bastos (2007) ao debruçar-se sobre o sistema judicial angolano, alega que apesar de estarem previstos na constituições diferentes garantias do acesso e assistência judicial do cidadão, a realidade do sistema de justiça pode concorrer a constranger a ação deste sistema na garantia dos direitos sociais, o da educação em particular, dos cidadãos se reivindicados. Ao abordar os constrangimentos no funcionamento dos tribunais, Bastos realça que estes não resultam nem da estrutura dos tribunais, nem da falta de definição dos deveres dos seus agentes, mas sim da sua funcionalidade prática em resultado de entraves provocados pela legislação, por vezes desadequada, no desempenho dos agentes e do funcionamento dos tribunais, o controlo do funcionamento desses agentes individualmente e da estrutura em si, as condições de trabalho e a remuneração, etc. Ao especificar esses fatores, Bastos (2007) diz que devido a "demora desnecessária" (p.185) dos processos, os resultados dos mesmos, geralmente, tornam-se inúteis porque ao sucederem fora do tempo, torna-os inúteis por ficarem desprovidos da importância que deu origem à lide. Também nas palavras da autora, há a falta de compromisso dos magistrados e outros funcionários no sistema de justiça com os processos que lhes são apresentados, resultando no não cumprimento dos prazos legais para a pratica dos atos. Fatores como estes elencados por Bastos, ilustram uma realidade que embaraça a satisfação dos direitos, entendendo que o acesso à justiça e a qualidade da justiça prestada é per si um direito fundamental que concorre para a realização dos demais direitos e a garantia dos direitos fundamentais.

É na fundamentação legal do direito à educação, bem como nos mecanismos legais para a sua reivindicação, que podemos situar a garantia formal não só do acesso à ela, mas também dos créditos para as ações que propiciem a possibilidade da educação escolar formal acontecer nos padrões de qualidade almejados. É também com base nessa 
fundamentação que se estabeleceram, quer na Lei Constitucional como na Constituição, e nas leis ordinárias que delas resultaram, as dimensões que informaram os aspectos cognitivos, normativos e políticos da atual política da educação.

A dimensão normativa da política educacional nesse período privilegiou os princípios do Estado democrático de direito. O conteúdo da política da educação no contexto da reforma educativa é anunciado em documentos reitores como a Lei Constitucional de 1992, a LBSE (ANGOLA, 2001a), de 2001, e na Constituição da República de Angola de 2010 (ANGOLA, 2010a).

Na perspectiva da democratização da educação, a Lei Constitucional de 1992 consolida as premissas para a implementação da democracia pluripartidária e para a ampliação do reconhecimento e garantias dos direitos e liberdades fundamentais dos cidadãos. É assim que no seu artigo $1 .^{\circ}$ do Título I (Princípios fundamentais) define que a República de Angola tem como objetivo fundamental a constituição de uma sociedade livre, democrática, de paz, justiça e progresso social.

Os aspectos da implementação da democracia multipartidária e da democratização da educação, democratização esta que não se deve limitar à garantia do acesso à escola, mas sim a consumação plena do direito à educação, desafia a necessidade de se conformar a política educacional aos princípios de uma educação para todos. O contexto de democracia pluripartidária contraria o período anterior (1975-1991), regido por um sistema de partido único que se sobrepunha às estruturas do governo por acreditar-se que “o partido [MPLA] é a força dirigente da revolução e o aparato do Estado é o principal instrumento nas mãos da classe trabalhadora, sob a liderança do partido, para atingir o seu domínio político e exercer o poder popular" (ANGOLA, 1977, p. 15-16, apud SOMERVILLE, 1986, p. 112). Neste cenário em que o MPLA ensaiava a construção de um estado socialista de orientação marxista-leninista, a emergência de outras forças políticas e movimentos sociais contrários à ideologia da classe dirigente eram institucionalmente vetados. Qualquer tentativa ao contrário era imputada como um ato criminal e, muitas das vezes, julgados como crime "contra a revolução" enquadrada na lei da segurança do Estado. Os seus mentores eram reputados como "inimigos da revolução", "contrarrevolucionários", "agentes do imperialismo”, dentre outros. 
A expectativa é a de que a proposta do Estado democrático e pluripartidário concorra à construção de um Estado que se funde no respeito das liberdades dos seus cidadãos, na garantia dos seus direitos civis, políticos e sociais, bem como na promoção e na salvaguarda do direito como instrumento mediador das relações sociais. Nessa perspectiva de organização política e social, a democratização da educação deixa de ser uma simples marca discursiva para que a escola se abra a todos, passando a ser um processo que, quando elaborado e implementado pelos diversos grupos sociais, garanta a prestação de uma educação escolar formal que atribua ao educando valores, princípios e conhecimentos conducentes à valorização da sua condição humana, da sua história e experiência de vida, da sua cultura e da sua inserção como sujeito ativo no processo de desenvolvimento da sua sociedade. É ao abrigo dessa Lei Constitucional de 1992 que é aprovada da LBSE de 2001, bem como o Decreto n. 2/05, que vão sustentar, normativamente, a efetivação da reforma educativa.

No âmbito da LBSE de 2001, com concretamente no artigo $2^{\circ}{ }^{\circ}$, reafirma-se que o sistema de educação é assente na Lei Constitucional (a de 1992, para o caso), sendo que o mesmo sistema de educação desenvolve-se em todo território nacional, e compete exclusivamente ao Estado a definição da sua política. Quanto à materialização da política da educação, apesar de as iniciativas de educação estarem abertas a outros promotores, cabe ao Estado, via Ministério da Educação, a definição das normas gerais da educação nos seus aspectos pedagógicos, andragógicos, técnicos e de apoio, e a fiscalização do seu cumprimento e da sua aplicação.

Para os objetivos gerais, a LBSE de 2001 propõe-se, no artigo 3. ${ }^{\circ}$, que a educação angolana deve buscar:

a) Desenvolver harmoniosamente as capacidades físicas, intelectuais, morais, cívicas, estéticas e laborais da jovem geração, de maneira contínua e sistemática, elevar o seu nível cientifico, técnico e tecnológico, a fim de contribuir para o desenvolvimento socioeconómico do país;

b) Formar um indivíduo capaz de compreender os problemas nacionais, regionais e internacionais de forma crítica e construtiva para a sua participação ativa na vida social, à luz dos princípios democráticos;

c) Promover o desenvolvimento da consciência pessoal e social dos indivíduos, em geral, e da jovem geração, em particular, o respeito pelos valores e símbolos nacionais, pela dignidade humana, pela tolerância e cultura da paz, a unidade nacional, a preservação do ambiente e a consequente melhoria da qualidade de vida; 
d) Fomentar o respeito devido aos outros indivíduos e aos superiores interesses da nação angolana na promoção do direito e respeito à vida, à liberdade e à integridade pessoal;

e) Desenvolver o espírito de solidariedade ente os povos em atitude de respeito pela diferença de outrem, permitindo uma saudável integração do mundo (ANGOLA, 2001a).

Definidos os objetivos, a LBSE propõe os princípios gerais, nos quais se deve reger o sistema de educação. Nessa perspectiva, esse sistema se assenta nos seguintes princípios:

- O da integridade (artigo $4 .^{\circ}$ ), que busca corresponder os objetivos da formação aos do desenvolvimento do país;

- O da laicidade (artigo 5..$^{\circ}$, que declara a independência do sistema de educação a qualquer religião;

- O da democraticidade (artigo 6..$^{\circ}$ ), que define o carácter democrático da educação pelo que "sem qualquer distinção, todos os cidadãos angolanos têm iguais direitos no acesso e na frequência aos diversos níveis de ensino e de participação na resolução dos seus problemas";

- O da gratuidade (artigo $7 .^{\circ}$ ), determinando a isenção de qualquer pagamento pela inscrição, assistência às aulas e material escolar aos alunos do ensino primário, quer no subsistema de ensino geral, quer no subsistema de educação de adultos;

- O da obrigatoriedade (artigo 8. $^{\circ}$ ), princípio a ser observado para todos os cidadãos que frequentam os subsistemas do ensino geral.

- O da língua (artigo 9. ${ }^{\circ}$ ), que privilegia a língua portuguesa como língua de ensino.

Em observância aos objetivos e aos princípios definidos na LBSE e tendo como propósito o de aumentar a eficácia e a garantia do direito à educação que transcenda o simples acesso à escola, as autoridades educativas (ANGOLA, 2009) definiram os objetivos da reforma da educação, bem como as atividades à sua efetivação: 
Quadro 12: Objetivos da reforma e as atividades para os efetivar

\begin{tabular}{|c|c|}
\hline Objetivos da reforma & Atividades para a efetivação dos objetivos \\
\hline 1. A expansão da rede escolar & $\begin{array}{l}\text { a. Universalização da classe de iniciação e do ensino primário de seis } \\
\text { classes; } \\
\text { b. Introdução e generalização da carta escolar }{ }^{58} \text { do ensino primário e } \\
\text { secundário; } \\
\text { c. integração das crianças com necessidades educativas especiais no } \\
\text { sistema nacional de ensino. }\end{array}$ \\
\hline $\begin{array}{l}\text { 2. A melhoria da qualidade de } \\
\text { ensino }\end{array}$ & $\begin{array}{l}\text { a. A reformulação, em profundidade, dos objetivos gerais da educação, } \\
\text { programas escolares, conteúdos, métodos pedagógicos, estruturas e } \\
\text { meios pedagógicos adequados à realidade angolana; } \\
\text { b. Melhoria das aprendizagens e enquadramento pedagógico dos } \\
\text { alunos; } \\
\text { c. Formação inicial e em exercício dos professores; } \\
\text { d. Modernização e reforço da inspeção escolar; } \\
\text { e. Melhoria da qualidade e da quantidade de manuais escolares; } \\
\text { f. Melhoria do trabalho metodológico e do processo docente-educativo } \\
\text { das escolas; } \\
\text { g. Garantia da participação da comunidade nos trabalhos da escola, isto } \\
\text { é, da relação entre a escola e a comunidade. }\end{array}$ \\
\hline $\begin{array}{l}\text { 3. O reforço da eficácia do } \\
\text { sistema de educação }\end{array}$ & $\begin{array}{l}\text { a. Construção de um sistema de monitoria e avaliação dos resultados } \\
\text { do processo de ensino-aprendizagem; } \\
\text { b. Melhoria do sistema de informação para a gestão educativa; } \\
\text { c. Formação de gestores escolares; } \\
\text { d. Melhoria na circulação de informação dos dados do processo de } \\
\text { ensino-aprendizagem. }\end{array}$ \\
\hline $\begin{array}{l}\text { 4. A equidade do sistema de } \\
\text { educação }\end{array}$ & $\begin{array}{l}\text { a. Garantia da igualdade de oportunidades a todos os cidadãos através } \\
\text { de um ensino primário de qualidade, atingindo particularmente as } \\
\text { classes mais desfavorecidas; } \\
\text { b. Redução das disparidades de género, atingindo particularmente os } \\
\text { portadores de deficiências psicomotoras e as assimetrias regionais no } \\
\text { acesso à educação. }\end{array}$ \\
\hline
\end{tabular}

Fonte: ANGOLA (2009)

58 A carta escolar é geralmente um instrumento de planeamento assente em documentos oficiais da iniciativa do poder central e de âmbito local que tem como questões as ações conducentes a melhoria da educação e definir a sua relação com a ação de um determinado governo. 
Para a dimensão política da política educacional, enunciou-se a necessidade de efetivação da educação que se salvaguardasse como um direito de cidadania. Conscientes da improdutividade do sistema e pela nova ordem mundial política mundial decorrente do desmembramento da URSS, seu principal aliado político, e do fim da guerra fria, o governo de Angola aprovou a Lei n. ${ }^{\circ} 13 / 01$, a LBSE e o Decreto n. ${ }^{\circ} 2 / 05$, (ANGOLA, 2005) que aprova o plano de implementação progressivo do novo sistema de Educação definido na LBSE. Essa lei, a face normativa da política da educação, é justificada, segundo a sua nota introdutória, pela vontade de realizar a escolarização de todas as crianças em idade escolar, de reduzir o analfabetismo de jovens e adultos e de aumentar a eficácia do sistema educativo.

Concretamente, a política da educação resultante da reforma de 2001 enfatiza a tendência desenvolvimentista da educação ao atribuir créditos à educação como a base do desenvolvimento económico. Quanto ao princípio da democratização da educação, a reforma propôs-se, pelo menos na declaração, a não limitar esse princípio ao acesso, mas sim ao provimento de educação de qualidade e à garantia da permanência dos alunos no sistema. Os princípios da transição automática de classe e a salvaguarda no sistema da condição e dos direitos dos alunos com necessidades especiais de aprendizagem ilustram esse alargamento. Essa democratização é também alargada à participação dos cidadãos na resolução dos seus problemas (artigo 6. ${ }^{\circ}$ da LBSE (ANGOLA, 2001a)).

Na dimensão cognitiva, por sua vez, a política educacional declarou a educação como elemento que concorre para a emancipação individual e também para o progresso social. Ela, a educação, tem o seu reconhecimento definido, em primeira instância, no artigo 21 da Constituição de 2010, intitulado "tarefas fundamentais do Estado" e no qual se declara na alínea $f$ a promoção de "políticas que assegurem o acesso universal ao ensino obrigatório, nos termos definidos pela lei”. A educação proposta para a garantia dessa emancipação individual e do progresso social, como já antes referenciado, circunscreveu os seus objetivos na "formação harmoniosa e integral do individuo, com vista a construção de uma sociedade livre, democrática, de paz e progresso social" (ponto 2 do artigo $1^{\circ}$ da LBSE (ANGOLA, 2001a)). 
A emancipação e o progresso social, preconizados pela Lei, pressupõem que, na realização da atividade educativa é essencial que se compreendam os fundamentos que devem sustentar a educação, a natureza do trabalho da educação e os fins a determinar, criando, assim, condições para que a educação proposta se oponha àquela que buscou a homogeneização ideológica e cultural dos angolanos. A essência dos fins da educação e a sua salvaguarda têm norteado o trabalho de teóricos da educação. Tanto que, para John Dewey (1996), ao se falar de fins de uma educação eficaz, impõem-se que eles sejam fundados em atividades e necessidades intrínsecas do indivíduo a ser educado, evitandose assim a definição de fins padronizados que negligenciam o potencial específico e as exigências de cada indivíduo, e não esquecendo-se que o aprendizado é algo que acontece ao indivíduo num determinado tempo e lugar.

Para além disso, ainda na óptica de Dewey, mais do que responder às orientações superiores sobre os fins da educação, deve-se valorizar e reconhecer cada experiência, fomentando-se assim o critério democrático do significado intrínseco para não nos tornarmos intelectualmente confusos pela necessidade de nos ajustarmos aos fins exteriormente propostos. Afinal, a educação busca a valorização do indivíduo e da sua experiência no seu lugar e no seu tempo.

A educação relacionada à experiência é também referenciada por Anísio Teixeira (1975). Na sua perspectiva, a "educação como processo de reconstrução é a reorganização da experiência, pelo qual lhe percebemos mais agudamente o sentido, e com isso nos habilitamos a melhor dirigir o curso nas nossas experiências futuras" (TEXEIRA, 1975, p. 17). Essas experiências, na sua classificação, apresentam-se em três tipos:

1) A experiência como fenómeno do mundo orgânico e não como instrumento em posse do homem na busca de conhecimentos do universo;

2) A experiência como apresentação consciente (conhecimento que desenvolve a análise e a indagação da sua própria realidade);

3) O nível de experiência submetido, leva o homem a inquietações e indagações, buscando assim a melhoria da sua obra (do seu universo).

Essas experiências, fruto da relação entre os homens, formam hoje a experiência humana como resultado da vivência acumulada. É essa experiência que sustenta o modus vivendi atual, na educação em particular, que é o exercício da práxis reiterativa - o uso da 
experiência dos nossos ancestrais, e da práxis descritiva - o uso da experiência para responder aos desafios da época atual, uma vez que "os objetivos do ensino e da educação consistem numa transformação dos conhecimentos em concepções ativas" (PISTRAK, 2011, p. 29). Depreende-se que a educação do homem reflete o processo histórico de desenvolvimento da humanidade, no qual o homem, "não é somente um produto, pois é precisamente o seu produtor" (MONDOLFO, 1967, p. 56).

Nisso, a educação como processo formal e científico é mais do que a passagem de um certo conteúdo de disciplina no qual a escola é provedora do conhecimento e de informação, e o educando é um mero receptor desses conteúdos. Ao contrário, retomamos o pensamento de Paro (2010), em seu sentido amplo a educação assenta na apropriação da cultura, a qual envolve conhecimentos, informações, valores, crenças, ciência, arte, tecnologia, filosofia, direito, costumes, enfim, tudo que a experiência humana proporciona na sua transcendência da natureza.

Nessa óptica, continuando com Paro, a educação entendida como apropriação da cultura requer que o homem que dela participa conserve a sua condição de sujeito detentor de vontade, enfim, como autor do processo educativo. Requer também que a preocupação da educação seja com o "homem na integridade da sua condição histórica, não se restringindo a fins parciais da preparação para o trabalho, para ter sucesso em exames ou para qualquer aspecto restrito da vida das pessoas” (PARO, 2010, p. 26).

\subsection{O acesso}

A garantia do acesso, traduzido na necessidade da universalização da escolarização primária é, a par da promoção de um ensino de qualidade, um dos aspectos mais referenciados na declaração da política da educação. A materialização do acesso está vinculado às atividades da implementação da reforma como o aumento de salas de aulas e a flexibilização ${ }^{59}$ das condições para matrículas. Ao contrário das lógicas da

\footnotetext{
${ }^{59}$ A flexibilização evoca a anulação de algumas exigências que podem condicionar o acesso das crianças à escola. O pagamento de uma taxa de matricula era um desses obstáculos. O outro que consideremos como um dos principais é a prova documental da identidade da criança para a realização da matricula, sendo a cédula de nascimento para as matriculas até a 4 classe, e o Bilhete de Identidade (RG-Brasil) para as
} 
garantia do acesso à educação nas propostas da política da educação antecessoras, inscreveu-se o atendimento das crianças com necessidades especiais de aprendizagem cuja maioria não se beneficiavam da educação devido à incapacidade do sistema de educação em atendê-las. O ensino particular é também tomado como relevante no aumento de vagas porque, se para a maioria dos utentes das escolas particulares das regiões urbanas esta modalidade de ensino é uma possibilidade de uma educação diferenciada, supostamente de melhor qualidade, para aqueles que podem arcar com os elevados custos que a mesma demanda, nas regiões peri-urbanas, particularmente em Luanda, a modalidade do ensino particular é, muita das vezes, a única opção existente devido à ausência da rede escolar pública. $\mathrm{O}$ ensino privado, particularmente o garantido pelas instituições religiosas, foi a única opção disponível para muitas regiões rurais com realce as mais afetadas pela guerra que; ou destruiu as infraestruturas disponíveis, ou isolou a região das outras.

Em 2008 e 2012 respectivamente, o Ministério da Educação tornou público alguns dados relativos ao acesso dos alunos ao sistema de educação depois de generalizada a reforma educativa ${ }^{60}$. Traduzido em números, o acesso na forma de evolução dos alunos matriculados nas diferentes classes do ensino obrigatório apresenta-se como no quadro a seguir.

Tabela 12: Evolução de alunos matriculados, 2001-2010

\begin{tabular}{|c|c|c|c|c|c|c|c|c|c|c|}
\hline & \multicolumn{3}{|c|}{ Antigo sistema } & \multicolumn{7}{|c|}{ Novo sistema } \\
\hline & 2001 & 2002 & 2003 & 2004 & 2005 & 2006 & 2007 & 2008 & 2009 & 2010 \\
\hline 莺 & 237.208 & 278.347 & 537.378 & 678.780 & 895.145 & 842.361 & 938.389 & 711.025 & 690.375 & 663.015 \\
\hline 茪 & 1.472 .874 & 1.733 .549 & 2.492 .274 & 3.022 .461 & 3.119 .184 & 3.370 .079 & 3.558 .605 & 3.851 .622 & 3.967 .886 & 4.189 .853 \\
\hline
\end{tabular}

Fonte: Angola (2013a)

demais classes. Acontece que o sistema de justiça não satisfaz a demanda do cidadão na busca deste documento, esta os seus serviços ausentes em algumas localidades.

${ }^{60}$ Fases de implementação da Reforma educativa: Preparação (2002-2012); Experimentação (2004-2010); Avaliação e correção (2004-2010); Generalização (2006 - 2011) e Avaliação Global (a partir de 2012). 
Pode-se perceber a evolução das matrículas de ano para ano. Apesar de o quadro discriminar os números em anos cobertos pelo antigo e pelo novo sistema de educação, o maior fator do aumento de alunos matriculados é essencialmente o aumento de salas de aulas que resulta da reabilitação da infraestrutura destruída durante a guerra, e a construção de novas escolas. Em 2002, foram assinados os acordos de paz que terminaram com a guerra. $\mathrm{O}$ fim da guerra proporcionou condições de segurança para que os cidadãos pudessem dedicar-se a outras atividades, sendo a educação uma delas. Também se verificou, apesar de ter sido lento, o retorno do controlo administrativo pelo Estado de muitas regiões do território angolano. Nesse período sobressaem os programas de reconstrução nacional pós-guerra iniciado pelo governo. Estes programas visaram essencialmente as infraestruturas que garantissem o desenvolvimento de programas económicos e a oferta de serviços sociais. Para a educação, foram construídas escolas e reabilitadas outras degradadas, quer pelo efeito direto da guerra, como pela falta de manutenção. A construção destas salas de aulas e a estabilidade política, concretamente a ausência da guerra e as privações e danos dela decorrentes, levaram muitos alunos para a escola, situação esta que pode não ser necessariamente um mérito da implantação de um novo sistema.

Para melhor elucidação da abrangência do atendimento para a garantia do acesso à educação, apresentamos dados sobre a população que pela idade é abrangida pela escolaridade obrigatória. Este fator pode também auxiliar na aferição dos índices de atendimento. Em dados apresentados pelo Instituto Nacional de Estatística (INE), em 2010, ilustra-se a população por grupos etários estimada ${ }^{61}$ para o período 2005-2008. Efetuamos para o interesse do estudo o recorte dos grupos etários abrangidos pela escolarização obrigatória.

\footnotetext{
${ }^{61}$ O último censo geral da população foi feito em 1970. O INE fez contagens parciais em 1983 e 1986 em algumas províncias. Esta é a razão de os dados do INE serem essencialmente feitos à base de projeções.
} 
Tabela 13: População em Angola estimada por grupos etários, 2005-2008/ por milhões

\begin{tabular}{|l|c|c|c|c|}
\cline { 2 - 5 } \multicolumn{1}{c|}{} & $\mathbf{2 0 0 5}$ & $\mathbf{2 0 0 6}$ & $\mathbf{2 0 0 7}$ & $\mathbf{2 0 0 8}$ \\
\hline $\mathbf{0 - 1 4}$ anos & 7.587 & 7.823 & 8.063 & 8.307 \\
\hline $\mathbf{5 - 4}$ anos & 3.103 & 3.197 & 3.294 & 3.395 \\
\hline $\mathbf{1 0 - 1 4}$ anos & 2.450 & 2.528 & 2.607 & 2.686 \\
\hline Total população & 2.034 & 2.098 & 2.162 & 2.226 \\
\hline
\end{tabular}

Fonte: Angola (2010b)

Notamos no confronto de dados dos Tabelas 13 e 14 os altos índices de atendimento da população abrangida pela escolaridade obrigatória. Pelo histórico dos índices de acesso à educação e atendendo ao crescimento de pelo menos duas mil matrículas anuais, apercebe-se, no quesito acesso, a busca do desafio da universalização da educação primária nesta faixa etária. Cremos que outros cenários sobre a universalização da educação primária podem revelar-se caso se alargue a população a atender. Pela história do provimento da educação em Angola, os índices de analfabetismo foram naturalmente deslocados para a população adulta. Assim, a alfabetização da população inscreve-se na demanda da satisfação do direito à educação, uma vez que a sua condição atual resulta da não satisfação desse direito na idade adequada.

Tabela 14: População 5-14 anos versus alunos matriculados no ensino público

\begin{tabular}{|l|l|l|}
\hline \multirow{2}{*}{$\mathbf{2 0 0 5}$} & População & 4.484 .000 \\
\cline { 2 - 3 } & Matrículas & 4.014 .329 \\
\cline { 2 - 3 } & Não atendidos & $\mathbf{4 6 9 . 6 7 1}$ \\
\hline \multirow{2}{*}{$\mathbf{0 0 0 6}$} & População & 4626.000 \\
\cline { 2 - 3 } & Matrículas & 4.212 .440 \\
\cline { 2 - 3 } & Não atendidos & $\mathbf{4 1 3 . 5 6 0}$ \\
\hline \multirow{2}{*}{$\mathbf{2 0 0 7}$} & População & 4.769 .000 \\
\cline { 2 - 3 } & Matrículas & 4.496 .994 \\
\cline { 2 - 3 } & Não atendidos & $\mathbf{2 7 2 . 0 0 0}$ \\
\hline \multirow{2}{*}{$\mathbf{2 0 0 8}$} & População & 4.912 .000 \\
\cline { 2 - 3 } & Matrículas & 4.562 .647 \\
\cline { 2 - 3 } & Não atendidos & $\mathbf{3 4 9 . 3 5 3}$ \\
\hline
\end{tabular}

Fontes: Angola (2010b) 
A evolução das salas de aulas, referida no balanço da reforma como o principal fator concorrente ao crescimento de alunos no sistema, apresenta os indicadores ilustrados no quadro a seguir.

Tabela 14: Evolução das salas de aula

\begin{tabular}{|l|c|c|c|c|c|c|c|c|c|}
\cline { 2 - 10 } \multicolumn{1}{c|}{} & \multicolumn{2}{c|}{ Antigo sistema } & \multicolumn{7}{c|}{ Novo sistema } \\
\cline { 2 - 10 } \multicolumn{1}{c|}{} & $\mathbf{2 0 0 2}$ & $\mathbf{2 0 0 3}$ & $\mathbf{2 0 0 4}$ & $\mathbf{2 0 0 5}$ & $\mathbf{2 0 0 6}$ & $\mathbf{2 0 0 7}$ & $\mathbf{2 0 0 8}$ & $\mathbf{2 0 0 9}$ & $\mathbf{2 0 1 0}$ \\
\hline Iniciação & & & & & & & & & \\
\hline Primário & 17.236 & 25.436 & 33.950 & 35.665 & 37.380 & 41.343 & 45.608 & 46.976 & 48.386 \\
\hline
\end{tabular}

Fonte: Angola (2010b)

Entretanto, os indicadores sobre o rácio de alunos por sala de aulas mostram que a evolução de salas de aulas, pelo menos até o ano de 2008, não eliminou a superlotação das turmas, apesar da pretensão do novo sistema em reduzir até o máximo de 45 alunos por cada turma.

Tabela 16: Rácio de alunos / sala de aula, 2005-2008

\begin{tabular}{|l|c|c|c|c|}
\cline { 2 - 5 } \multicolumn{1}{c|}{} & $\mathbf{2 0 0 5}$ & $\mathbf{2 0 0 6}$ & $\mathbf{2 0 0 7}$ & $\mathbf{2 0 0 8}$ \\
\hline Aluno/sala & 124 & 124 & 119 & 114 \\
\hline
\end{tabular}

Fonte: Angola(2010b)

Apesar dos números mostrarem o crescimento das salas de aulas, o balanço da reforma educativa apresentou ainda muitos casos, segundo o mesmo, de salas de aulas inadequadas para o exercício do ato educativo. Estas salas são essencialmente espaços ao ar livre (debaixo de árvores), varandas de prédios escolares, capelas e espaços feitos de chapa de zinco. Apesar de se apresentar indicadores que informam a realidade concreta destas condições precárias, o facto é que, por um lado, a existência das mesmas obstrui a garantia do acesso; por outro, a manutenção do risco de se garantir o acesso sem as devidas condições para o atendimento dos alunos matriculados no sistema. Esses 
números sobre as salas de aulas, em outra perspectiva, não apresentam uma destrinça entre as províncias, que possam permitir que se verifiquem o estado das assimetrias regionais. Devido ao histórico das políticas do desenvolvimento, é útil a demonstração em como esses números sobre a evolução das salas de aulas atendem às devidas necessidades das diversas regiões do país.

No histórico da garantia do acesso houve sempre a assimetria natural entre as regiões urbanas em oposição às rurais e também, a assimetria entre as regiões no litoral do país com as situadas no interior. Nos números divulgados sobre a evolução da educação e do ensino em Angola no período 2002-2008 fala-se que 66\% do total de matrículas foram feitas no interior contra os 33,7\% no litoral. Esse dado mostra uma realidade que pode dar a ideia corrompida da redução das assimetrias devido a não demonstração da densidade populacional (em idade escolar) de cada província e a correlação do atendimento entre esta população e os alunos matriculados em cada nível de ensino.

\subsection{Ensino privado}

A atual relevância do ensino privado é representada pelo crescimento da população atendida por essas escolas. Segundo o Inquérito Integrado sobre o Bem-Estar da População (IBEP) (ANGOLA, 2011c), a escola pública é, entre as outras, incomparavelmente a que mais alunos integra, $78 \%$ do total da população. A escola privada é a segunda mais citada, com $17 \%$, as religiosas surgem em terceiro lugar, com $5 \%$. O recurso à escola pública é quase universal na zona rural $(97 \%)$, onde existem muito poucas instituições privadas de ensino. Nas zonas urbanas, a percentagem diminui para $69 \%$, e o acesso a escolas privadas aumenta para $25 \%$. O acesso a escolas ligadas às igrejas apresenta um maior equilíbrio entre as áreas rurais e urbanas, com 4\% e 5\%, respectivamente.

O ensino privado na República de Angola resulta da nova ordem política, depois de oficialmente proibido em 1975. O ensino privado é formalmente autorizado em 1991, no contexto das mudanças políticas desse período. Pelo Decreto 21/91, o Conselho de Ministros fundamenta esta lei como o reconhecimento do papel que as entidades privadas 
podem desempenhar no auxílio do Estado no exercício das tarefas da educação. E também pela Lei n.81/91, que cria as normas reguladoras da concessão de autorização para a abertura e funcionamento de estabelecimentos de ensino particular. A abertura dos estabelecimentos de ensino particular está sujeita à autorização do Ministério da Educação.

Todavia, essa é a formalização de uma modalidade de ensino que já era praticada, principalmente nas comunidades não atendidas pela rede das escolas públicas. Num estudo sobre essa questão, Maria J. S. M. Ferreira (2005) diz que antes da aprovação da lei sobre o ensino particular, existiam em atividade escolas que ela agrupa em tipologia. As mais comuns eram as escolas que surgiram espontaneamente para atender a alguns segmentos da população. Estas, também designadas por salas de explicação, surgiram como salas onde se ensinava a ler e a escrever por não haver lugar para todos nas escolas existentes. Outro tipo são as salas de aulas anexas às instituições religiosas para atender às crianças das comunidades religiosas fora do sistema, cujo financiamento era garantido com uma contribuição dos alunos. É de realçar nessas escolas a particularidade de aceitarem alunos com idades muito superiores às definidas pelo sistema por eles não terem tido acesso à escola pública no período adequado.

São essas escolas que vão solicitar a sua legalização e o seu reconhecimento como escolas privadas. Buscam também a sua atuação no setor do ensino privado as comunidades religiosas, principalmente à igreja católica, que vai requerer a desnacionalização de suas instalações confiscadas em 1975 para nelas continuarem com os seus projetos educativos. Alguns interesses econômicos, ligados à classe dirigente do Estado, surgem com vários projetos de escolas privadas com fins lucrativos. São estes últimos que vão desenvolver uma rede de escolas melhor equipadas e com professores devidamente qualificados, mas longe ao alcance da maioria da população, se atendermos à condição socioeconômica que segundo os Índice do Desenvolvimento Humano situamse maioritariamente na linha da pobreza.

Em 1992, o Decreto 43/02 do Conselho de Ministros (ANGOLA, 2002) busca ajustar o regulamento da abertura e do funcionamento das escolas do ensino privado para o nível não superior, criando para o efeito o respectivo estatuto. Entre os vários princípios 
salientam-se a "intervenção do Estado" (artigo 3). Esta intervenção é no "domínio da constituição e funcionamento de ensino privado obedece ao critério prioritário de garantia e fazer respeitar o direito fundamental dos cidadãos de aprender e de ensinar”. Segundo o artigo 3 desse Decreto, deve, então, o Estado:

a) garantir a liberdade de instituição e funcionamento do ensino privado;

b) promover as condições que possibilitam a sua criação e funcionamento;

c) fiscalizar a qualidade do ensino em termos científicos e pedagógicos;

d) velar pelo cumprimento das normas legais.

Define-se também no artigo 40, "apoio", que o "Estado poderá conceder incentivos ao investimento nos termos e na condições que vierem a ser regulamentados, visando a melhoria da qualidade do ensino e a igualdade de oportunidade no acesso" (ANGOLA, 2002).

Na realidade da CRA de 2010, o Decreto Presidencial n. 207/11, “aprova o Estatuto das Instituições de Ensino Privado até ao Ensino Secundário”. Realçamos neste o alargamento do "apoio" (ANGOLA, 2011b, art. 4") a prestar às escolas particulares. Para além dos incentivos de investimentos previstos na lei anterior, o Executivo 62 "pode ainda conceder apoio através do fornecimento e pagamento do corpo docente, do fornecimento de material escolar, desde que reconheça a importância do estabelecimento e a insuficiência ou falta de instituições públicas na região, para a garantia da escolaridade obrigatória" ((ANGOLA, 2011b, art. 4º , ponto 2). Esse apoio é prioritário às classes do ensino primário, incluindo a iniciação, e concedidos às instituições já licenciadas. Pode ser alargado para os outros ciclos, desde que se reconheça a importância das mesmas na região, sem prejuízo a parceiras público-privadas.

\section{4 $\mathrm{O}$ atendimento}

$\mathrm{O}$ atendimento é aqui também resumido nas condições materiais criadas para o desenvolvimento das atividades pedagógicas nas escolas e pelo rendimento interno dos alunos no sistema, isto é, as taxas de promoção, de reprovação e de abandono

\footnotetext{
${ }^{62}$ Designação do governo após a adopção da CRA de 2010.
} 
apresentadas pelo sistema. Segundo os dados disponíveis no balanço do governo de Angola sobre a reforma educativa, os prédios escolares, em grande número, apresentaram-se degradados. As turmas continuam superlotadas, como demonstrado no rácio aluno por sala de aula, e a condição das qualificações dos professores não melhoraram substancialmente. Os professores integrados no sistema continuaram sem se beneficiar de formação que os permitisse atualizarem-se e também a lidarem com as exigências do novo material a sua disposição e dos pressupostos da reforma. As exigências da monodocência, isto é, a obrigatoriedade de ser um único professor a leccionar todas as disciplinas da $1^{\mathrm{a}}$ à $6^{\mathrm{a}}$ classe, prescreveram a necessidade de se ter professores com melhores qualificações académicas no sistema.

Esta exigência deve-se a razão dos professores terem que leccionar conteúdos de disciplinas que no anterior sistema eram reservados para o nível posterior. Fala-se constantemente das dificuldades em lidar com o ensino da estatística e da geometria na disciplina de matemática na 6 . $^{\mathrm{a}}$ classe, por exemplo. Reclama-se também, na voz dos próprios professores e do SINPROF, da forma como se lida com a disciplina de educação musical $^{63}$. Alega-se que em momento algum da sua formação geral e profissional os professores experimentaram a educação musical, o que os inabilita de ministrarem as matérias dos programas para a disciplina que cobrem desde o ensino das notas musicais, a leitura de partituras musicais, o canto e alguns instrumentos musicais. Outro foco de reclamação é a disciplina de educação física. Os professores acreditam que no ensino primário, a educação física não se deve limitar ao ensino de jogos infantis. Reconhecem a necessidade de conhecimentos que os permitiria transformar as aulas de educação física num momento de trabalho da condição psicomotora dos alunos, a sua condição física, o experimento de várias modalidades desportivas e a formação da consciência sobre o valor da relação entre a educação física e a saúde física e a iniciação na prática desportiva.

Acontece que o currículo da formação geral e profissional dos professores, mesmo no contexto da reforma, não contempla a educação física como componente da formação. A própria reforma educativa não desenvolveu mecanismos, nos princípios da formação

\footnotetext{
${ }^{63}$ Disponível em: <http://www.opais.net/pt/opais/?det=23721〉. Acesso em: 22 mar. 2014.
} 
contínua, que proporcionasse aos professores algumas competências para lidarem com as exigências de uma disciplina que se julga essencial na formação integral das crianças.

Ainda sobre a questão dos constrangimentos reportados, aborda-se a dificuldade da distribuição dos manuais para os alunos. A questão dos manuais escolares incorporouse como demanda ao ser identificado como um dos fatores que condicionavam o desenvolvimento da atividade docente. Apesar de os mesmos terem sempre sido definidos como de distribuição gratuita desde a reforma de 1978, os manuais foram ao longo do tempo se tornando inacessíveis para a maior parte dos alunos no sistema, principalmente os das regiões peri-urbanas e rurais atingidas profundamente pela guerra. A crise económica que o país viveu desde o princípio da década de 1980 condicionou a capacidade de se produzir quantidades de manuais para as necessidades impostas pelo sistema de mercado.

A quase nula capacidade da produção local implicou a produção dos manuais em mercados externos. Dos 3,3 milhões de manuais produzidos em 1988/90, apenas 0,5 foram de produção local (WORLD BANK, 1992). Esta condição exigia maiores esforços financeiros e também melhor articulação logística do Ministério da Educação, o que não era devidamente garantido pelo próprio Ministério da Educação devido a suas próprias limitações orçamentais e também por imperativo da cultura de funcionamento dos vários organismos do Estado.

No seu diagnóstico de 1986, o Ministério da Educação encarou estas culturas como condicionantes ao desenvolvimento da política da educação proposta. Por exemplo, no caso dos manuais, até que os mesmos chegassem às escolas, o processo relativo aos manuais estava condicionado à aprovação do programa e do orçamento pelo conselho de Ministros, à programação financeira do Ministério das Fianças e do Banco Nacional de Angola (Banco Central), ao Ministério do Comércio Externo para os procedimentos da importação e do Ministério dos Transportes para todas as fases relativas ao transporte dos mesmos. Se levarmos em consideração que, primeiro, nem sempre os recursos financeiros estavam disponíveis em razão da cadeia de prioridades e, segundo, a débil fluidez dos processos nos diferentes órgãos do aparelho do Estado, os manuais escolares ganhavam necessariamente a condição de bens escassos no sistema de educação. A 
escassez e o desenvolvimento de práticas de corrupção no país e a incapacidade da ação fiscalizadora do Estado sobre a questão transformaram os manuais escolares em produto com valor de mercado. Porém, mesmo nos contextos em que a população detinha algum poder de compra, os manuais, às vezes, não estavam disponíveis.

Esse histórico ampliou a relevância dos manuais escolares na questão sobre o atendimento como um dos elementos das condições que se devem proporcionar para que a educação escolar se efetive a contento. Por isso, realçou-se a sua gratuidade no sistema e elaborou-se um orçamento adequado às necessidades. Esse orçamento possibilitou o aumento da produção de manuais. Mas, a operacionalização dos processos de distribuição de manuais até aos destinatários, os alunos, provou-se pouco eficaz. Os manuais continuam ausentes em muitas escolas e em algumas chegam algum tempo após o início das aulas. Mesmo com a perspectiva da criminalização da sua comercialização, a venda de manuais escolares é uma realidade do mercado informal.

O rendimento interno é tomado como o principal indicador do atendimento no sistema, pelo balanço efetuado, a reforma educativa, apesar de acreditarmos que ao se centrar a análise do mesmo nas taxas de promoção, de reprovação e de abandono, limitase à discussão de questões como a natureza da educação proporcionada aos alunos e também à busca da equidade no atendimento se considerarmos a diversificação dos utentes da escola. De qualquer modo, na perspectiva deste estudo, as taxas referidas elucidam-nos sobre os mecanismos criados no sistema de educação para a efetivação do direito à educação.

No que diz respeito à progressão, ainda segundo os dados disponibilizados pelo Ministério da Educação (ANGOLA, 2013a) no seu balanço à reforma educativa, no ensino primário, em cada 1000 alunos que ingressaram na $1 .^{\mathrm{a}}$ classe, 831 concluíram a 6. ${ }^{\mathrm{a}}$ classe, dos quais 571 alunos sem repetição de classe, o que corresponde ao índice de 57,1\%. Outros 209 alunos concluíram com uma repetição de classe, correspondendo a $21 \%$, e somente 51 alunos concluíram o ensino primário com duas repetições de classe 5,1\%. Quanto ao abandono, 165 alunos, 17\%, abandonaram o ciclo do ensino primário. 
Em termos comparativos, o rendimento interno é representado no Tabela 17.

Tabela 17: Rendimento interno (taxas de aprovação, reprovação e abandono) ${ }^{64}$

\begin{tabular}{|l|c|c|c|c|c|c|}
\cline { 2 - 6 } \multicolumn{1}{c|}{} & \multicolumn{3}{c|}{ Antigo sistema } & \multicolumn{3}{c|}{ Novo sistema } \\
\hline Aprovado & Reprovado & Abandono & Aprovado & Reprovado & Abandono \\
\hline $\begin{array}{l}\text { Ensino } \\
\text { Primário }\end{array}$ & $42 \%$ & $32 \%$ & $26 \%$ & $91,10 \%$ & $6,08 \%$ & $2,82 \%$ \\
\hline
\end{tabular}

Fonte: Angola (2013a)

Apresenta-se nesta tabela uma comparação das percentagens dos indicares do rendimento interno do sistema de educação nas classes do ensino primário recolhidos na fase de experimentação ( aplicação da reforma em algumas escolas, classes e turmas) em que se pretende mostrar o crescimento da taxa de aprovação e a acentuada redução das taxas de reprovação e de abandono.

Estas percentagens, ao serem analisadas como fluxo no novo sistema e comparados entre os da fase de experimentação e os da generalização, nota-se uma ligeira diferença entre os mesmos, reduzindo as taxas de aprovação e aumentando as de reprovação e abandono. O cenário dessas taxas de fluxo podem estar relacionados basicamente com a adopção da transição automática em algumas classes no ensino primário. Entretanto, não nos deparamos com evidencias sobre as causas das altas taxas de promoção nas outras classes da não transição automática. As necessidade de evidencias é fundamentada por reconhecermos que a generalização da reforma educativa não implicou a superação dos obstáculos ao atendimento condigno dos alunos inseridos no sistema de educação.

\footnotetext{
${ }^{64}$ As taxas referem-se apenas aos dados da fase de experimentação devido à inexistência de dados sobre o último ano da fase de generalização, 2012.
} 
Sobre o fluxo, o novo sistema apresenta os seguintes dados destrinçados entre as fases de experimentação e da generalização.

Tabela 18: Taxas de fluxo: experimentação (2004-2010)

\begin{tabular}{|l|l|l|l|l|l|l|l|}
\hline \multirow{2}{*}{ Taxa } & \multicolumn{7}{|c|}{ Classe } \\
\cline { 2 - 9 } & $\mathbf{1 .}^{\mathbf{a}}$ & $\mathbf{2 .}^{\mathbf{a}}$ & $\mathbf{3 .}^{\mathbf{a}}$ & $\mathbf{4 .}^{\mathbf{a}}$ & $\mathbf{5 .}^{\mathbf{a}}$ & $\mathbf{6 .}^{\mathbf{a}}$ & \\
\hline T.Pro & 96,5 & 86,5 & 93,5 & 87,5 & 95 & 88 & \\
\hline T.Re & 0 & 12,5 & 0 & 12 & 0 & 12 & \\
\hline T.Aba & 3,5 & 1 & 6,5 & 0,5 & 5 & 0 & \\
\hline
\end{tabular}

Tabela 19: Taxas de fluxo: generalização (2006-2011)

\begin{tabular}{|c|c|c|c|c|c|c|}
\hline \multirow{2}{*}{ Taxa } & \multicolumn{6}{|c|}{ Classe } \\
\hline & $10^{\mathrm{a}}$ & $20^{a}$ & 3. ${ }^{\mathrm{a}}$ & $4 .^{a}$ & $5 .^{\mathrm{a}}$ & $6 .^{a}$ \\
\hline T.Pro & 84 & 81 & 84 & 83 & 87 & $\mathrm{a}$ \\
\hline T.Re & 0 & 7 & 0 & 8 & 0 & $\mathrm{a}$ \\
\hline T.Aba & 16 & 12 & 16 & 9 & 13 & $\mathrm{a}$ \\
\hline
\end{tabular}

Fonte: Angola (2013a)

Legenda: T. Pró $=$ Taxa de Promoção; T. Re = Taxa de Reprovação; T. Aba = Taxa de abandono; a. = dados não fornecidos.

Comparados, o anterior e o atual sistema, os indicadores apresentam a seguinte configuração. Nos dados do MED (ANGOLA, 2013 a), o antigo sistema de educação apresenta taxas de aprovação de $41,6 \%$, ao passo que o novo sistema de educação apresenta $61 \%$ como taxas de aprovação. O crescimento nos indices de aprovação é de 25,9\%. Em contraste, a reprovação apresenta um decrescimo de 15,4\%, devido a diferença entre os $29,4 \%$ do antigo sistema de educação e a taxa de $13,9 \%$ do novo sistema. Quanto ao abandono escolar, se no antigo sistema as taxas eram de 29,4\%, no novo sistema estas taxas cairam para $18,4 \%$, o que causa um decrescimo de $11 \%$. 
Os dados acima mostram uma redução dos índices de abandono. Mas, não nos foi possível discernir por esses dados os fatores que ao longo dos anos concorreram para o abandono escolar e também para o atraso escolar. A não reprovação nas classes de transição do ensino primário, e também o aumento do número de salas de aulas concorrem para a redução desses índices. Mas, resumimos a seguir 3 abordagens produzidas por inquéritos múltiplos e que caracterizaram os índices do abandono escolar, o atraso escolar e as razões que os fomentam. É crença nossa que sem uma abordagem de cada uma das razões apresentadas, a efetivação do direito à educação continuará condicionada.

Segundo o Inquérito de Indicadores Múltiplos (MICS), por meio de estudos realizados pelo Instituo Nacional de Estatística (INE) em parceira com o Unicef (ANGOLA; UNICEF, 1997) constata-se que os índices de abandono crescem com o adiantar das idades dos alunos. Foram registrados $71 \%$ dos abandonos em dois anos letivos $\left(1994 / 95\right.$ e 1995/96) ${ }^{65}$, esse percentual refere-se a alunos com mais de 10 anos de idade. A tendência é inversa, em relação à classe frequentada, registrando-se uma queda considerável com o aumento da última classe frequentada. A maior parte destes abandonos foi registrada antes da conclusão do $1^{\circ}$ nível ${ }^{66}$ de base, $88 \%$, sendo a $1 .^{\mathrm{a}}$ classe a que regista maior ocorrências: $29 \%$.

Em relação às taxas de abandono nos anos (994/1995 e 1995/96, as mesmas situam-se a volta dos $21 \%$, revelando que 1 entre 5 crianças abandonaram a escola. Se desagregados os dados por áreas de residência, na zona rural, a relação passa para 1 em 4 crianças, enquanto à nível das regiões geográficas, as regiões Norte e Centro Sul apresentam taxas similares às da zona rural, 29\%, contrariando a média das áreas urbanas que é aproximadamente de 15\%. Sobre o gênero, a taxa mostra existir maior tendência das meninas (23\%) abandonarem a escola do que os rapazes (19\%). O MICS de 1996 apresenta também as razões evocadas pelos inqueridos sobre o abandono.

Na razão relativa à "indisponibilidade dos recursos de educação" que representa o total de $34 \%$, a razão que mais se evoca é "a escola não abriu" com 15\%, sendo a zona

\footnotetext{
${ }^{65}$ Nessa época o ano letivo compreendia o período de Setembro de um ano civil a Maio do ano seguinte.

${ }^{66}$ No antigo sistema, no ensino de base, o $1^{\circ}$ nível comportava as classes da 1 a 4 . O $2^{\circ}$ nível as classes da $5^{\mathrm{a}}-6^{\mathrm{a}}$, e o $3^{\mathrm{o}}$ nível as classes da $7^{\mathrm{a}}-8^{\mathrm{a}}$.
} 
rural a que mais incidências apresenta (20\%) contra os 5\% da urbana. A "falta de professores" (10\%) é a segunda maior causa do abandono, tendo a zona rural $14 \%$ dos casos, e a urbana apenas 3\%. A "distância da escola" representa 5,4\%, e a "falta de vagas" representa $4 \%$, sendo as maiores ocorrências verificadas na zona urbana (12\%).

As razões "socioculturais" (34,6\%) desdobram-se nas seguintes: $8,7 \%$ dos inquiridos consideram que "a educação não é importante", 9\% apresentam a "falta de documentos" como a razão, sendo a maior relevância para a área urbana (15\%). Outra razão é "não tem idade" para a escola (15\%) que demonstra a possibilidade de a população não reconhecer ou conhecer a idade oficial para a admissão na escolar. Nas razões "socioeconômicas" que representam 15\% das principais causas do abandono escolar, o aspecto "Não têm dinheiro", com 9\% é a razão mais evocada para justificar o abandono escolar, principalmente na zona urbana (12\%), o "precisa trabalhar", como 5\%. As razões ligadas à "saúde" têm o índice de $9,9 \%$ do total das causas relacionadas ao abandono escolar.

Devido aos ambientes socioeconômico e político nos quais a educação foi sendo realizada, o que influencia as opções políticas, trazemos dados produzidos pelo MICS 2003 para refletirmos sobre os índices do abandono e da evasão escolar e, também, a relação dos mesmos no gênero. Este inquérito do INE e da Unicef abordou especificamente a situação das crianças e das mulheres angolanas no início do milénio. Na questão do gênero, comparando os dados, constata o MICS um facto positivo que é o de não existirem disparidades entre rapazes e raparigas que a nível nacional frequentam a escola em números iguais. A tendência mantém-se se comparado com o MICS de 1996 (ANGOLA; UNICEF, 1997), que também registrou diferenças mínimas nas taxas de escolarização dos rapazes e das meninas que era de 4\%. Mas, as taxas de sucesso escolar por gênero revelam outra face da questão em que as meninas se encontram em desvantagem. Em nível nacional, 79\% dos rapazes que ingressam na 1. ${ }^{\text {a }}$ classe atingem eventualmente a $5 .^{\mathrm{a}}$ classe, em contraste com os $73 \%$ das raparigas. A diferença maior verifica-se na região Este, onde dos $70 \%$ dos rapazes que ingressam na 1. ${ }^{a}$ classe chegam eventualmente à 5 . $^{\text {a }}$ classe, enquanto apenas $56 \%$ das raparigas o fazem, mostrando este grupo taxas mais elevadas de desistência. 
Concernente à progressão das crianças no sistema, o inquérito centrou-se no grupo etário com a taxa mais elevada de frequência do ensino primário ${ }^{67}$, as crianças de 11 anos que representam 79\%. Nessa idade, as crianças deveriam frequentar a sexta classe. Mas, apenas $2 \%$ destas crianças o fazem. A vasta maioria das crianças de 11 anos (91\%) ainda frequenta entre a $1 .^{\mathrm{a}}-4 .^{\mathrm{a}}$ classe.

As razões que produzem os obstáculos ao normal progresso das crianças (no geral não apenas as de 11 anos) continuam a ser as mesmas já identificadas pelo MICS de 1996, nomeadamente a falta de professores, a fraca infraestrutura e a baixa produtividade do sistema de educação, a entrada precoce no mercado do trabalho, o baixo rendimento da família e a falta de material escolar. O nível socioeconômico dos agregados familiares continua a influenciar a capacidade das suas crianças de aceder ao ensino básico. Por exemplo, como ilustrado neste inquérito, no nível da educação primária, a taxa de frequência das crianças dos maiores níveis econômicos é duas vezes superior à taxa de frequência das crianças dos agregados socioeconomicamente mais vulneráveis. Nas 5. ${ }^{\mathrm{a}} \mathrm{e}$ 6. ${ }^{a}$ classes do curso básico a taxa de frequência das crianças de um nível socioeconômico mais baixo é 16 vezes menor do que a dos agregados familiares pertencentes aos níveis socioeconômicos mais elevados.

As causas mais apontadas dos níveis muito baixos de frequência do ensino básico registrado entre as crianças dos agregados familiares mais vulneráveis estão assim resumidas (ANGOLA; UNICEF, 2003):

- A entrada precoce no mercado de trabalho, com taxas de $43 \%$ das crianças desfavorecidas em relação a 17\% das com o nível socioeconômico elevado.

- As baixas taxas de registo de nascimento conducente à falta de documentos privam o acesso à escola porque uma prova de identidade é exigida, principalmente depois da $4 .^{\mathrm{a}}$ classe.

- O material escolar, sobretudo quando o gratuito não chega à escola (o que é muito recorrente), os familiares são obrigados a recorrer ao mercado, o que nem sempre está ao alcance dos desfavorecidos.

\footnotetext{
${ }^{67}$ Neste período já vigorava o ensino primário com 6 classes ( $1^{\mathrm{a}}-6^{\mathrm{a}}$ classe $)$.
} 
Segundo este inquérito, a taxa de frequência do ensino básico é muito dependente do nível de rendimento dos agregados familiares. As crianças dos níveis socioeconômicos mais baixos têm $120 \%$ menos de probabilidade de frequentar o ensino primário do que uma criança do nível socioeconômico mais elevado. Em suma, a dimensão dos problemas do sistema de educação é revelado pelo menos entre os grupos mais desfavorecidos, nos quais $84 \%$ não frequentam a 5. ${ }^{\mathrm{a}}-6 .{ }^{\mathrm{a}}$ classe na idade recomendada.

Outro inquérito também nesta abordagem é o IBEP (ANGOLA, 2011c), que cobre o período 2008-2009, realizado 7 anos após à aprovação da LBSE e 6 após o fím do conflito armado. Neste, $76 \%$ das famílias urbanas e 55\% das rurais declararam ter acesso à escola até um raio de $2 \mathrm{~km}$ da sua residência. Todavia, 29\% de crianças têm ainda de percorrer mais de $2 \mathrm{~km}$ diariamente para terem acesso à escola. Num contexto de carência acentuada de transportes públicos, o que eleva os gastos com os transportes, nem sempre ao alcance das famílias de baixo rendimento, e também porque não existe o subsídio de transporte para os estudantes nem a componente de transporte escolar.

Constata-se também que o acesso não é ainda universal e $26 \%$ das crianças na faixa dos 6-9 anos nunca frequentou a escola, indicador da não escolarização na idade mais indicada, em que o ensino é obrigatório. A situação agrava-se quando se discorrem os dados sobre a frequência da educação pré-escolar que em nível nacional é de 9\%. Dentre as crianças nas zonas urbanas, $11 \%$ frequenta o ensino pré-escolar, comparativamente a apenas $7 \%$ nas zonas rurais. Os dados do IBEP revelam ainda que o acesso à educação pré-escolar em nível nacional é inferior a 10\%, estando muito distante da meta de obrigatoriedade universal. Nas áreas rurais, onde a disponibilidade de centros infantis é reduzida, o acesso é limitado a apenas $7 \%$ das crianças.

Sobre as razões da não frequência a educação pré-escolar, o IBEP (ANGOLA, 2011c) resume-as nas seguintes:

- A falta de serviço pré-escolar na área de residência, as zonas rurais com menor cobertura de serviço o que eleva as percentagens de crianças fora em $93 \%$.

- A percepção dos pais que consideram os filhos demasiados pequenos para frequentarem a escola representa $38 \%$. 
- O custo dos serviços, particularmente nas áreas urbanas onde poderão estar mais disponíveis serviços privados.

O abandono escolar é também abordado no IBEP, que o estima em 1,3\%, calculado no quociente entre os alunos matriculados no letivo corrente na altura, mas que não frequentaram a escola, e os que frequentaram. Mas essa taxa cresce com o aumento da idade dos alunos. Quanto ao gênero, a tendência é semelhante, mas a percentagem das meninas matriculadas e a frequentar a escola é menor do que a dos rapazes. Dentre a população entre 6-17 anos, 22\% não frequentaram a escola os 12 meses que antecederam o inquérito. As razões, principalmente, nas zonas urbanas, são os custos associados à educação; nas zonas rurais, a falta de professores, que é tida como a principal razão, e também a distância a percorrer para chegar à escola.

Nas razões socioculturais, os inquiridos referiram-se a questão de "não gostar de estudar". Quem mais invoca esta razão são as faixas dos 10-11 anos e 15-17 anos, 10\% e $14 \%$, respectivamente. Para as raparigas, sobretudo depois dos 12 anos, as razões principais são os encargos domésticos, que afetam mais as crianças no ensino primário, cerca de $8 \%$. A gravidez, por sua vez, contribui em 7,5\% para o abandono ou não ingresso na escola, mas há diferenças entre as faixas etárias: $3 \%$ de casos de gravidez muito precoce aos 12-14 anos e 7\% nos 15-17 anos. Finalmente, a necessidade de trabalhar afeta a escolarização de $6 \%$ dos jovens dos 15 anos aos 17 anos, distribuídos de forma igual entre o ensino primário e secundário.

Na questão do atraso escolar, segundo os dados do IBEP, estima-se que 59\% das crianças e adolescentes dos 12 aos 17 anos frequentam atualmente o ensino primário, em vez do secundário, indicando atraso escolar. As diferenças do local de residência são significativas nessa faixa etária, registrando a zona rural a proporção mais elevada, $67 \%$. O Cunene ${ }^{68}$ é a província onde se registra o maior atraso escolar, já que $81 \%$ de adolescentes dos 12 aos 17 anos ainda frequenta o ensino primário. Luanda registra a menor percentagem de adolescentes com atraso escolar, $45 \%$. As razões do atraso escolar radicam essencialmente na entrada tardia na escola, para além das reprovações. Cerca de

\footnotetext{
${ }^{68}$ Esta província do extremo sul de Angola faz fronteira com a Namíbia, o que a converteu no maior palco da guerra em Angola, com a destruição acentuada das infraestruturas. Nos últimos anos, a mesma tem sido assolada por ciclos de seca e de enchentes.
} 
metade das crianças com seis anos ou mais (48\%) entrou na escola tardiamente com um atraso que varia entre 1 e 4 anos em relação ao previsto no sistema educativo. Nas cidades, a probabilidade de as crianças entrarem tarde para a escola é 1,5 vezes inferior em relação à das crianças nas zonas rurais. $\mathrm{O}$ atraso nas áreas rurais tem como causa $\mathrm{o}$ trabalho infantil, segundo os vários estudos compilados pelo IBEP.

Outro fator sobre o atendimento revelado pelo balanço é a questão linguística. $\mathrm{O}$ mesmo refere que a língua portuguesa continua a ser de fraco domínio de um segmento considerável de professores a servirem no sistema, o que condiciona o aprendizado dos alunos. Assim, a escola não se capacita ela própria para proporcionar a franjas consideráveis de alunos o domínio do instrumento linguístico oficial nas transações formais no contexto social e político.

O Instituto Nacional de Estatística (2012), sobre a situação linguística em Angola, apresenta a seguinte distribuição da população segundo a língua materna. O português, língua oficial de Angola, é falado por 39\% da população. A língua nacional Umbundu tem 26\% de falantes; a Kikongo, 14\%; o que torna essas três línguas as mais representativas como língua materna. Mostra-se também que a língua portuguesa tem sua supremacia fundada no estatuto político que lhe é reservada e não na sua representatividade nos contextos sociais em Angola. Mas, a representatividade das línguas mencionadas não deve ser base para a subjugação das outras minorias linguísticas, principalmente na realidade da educação escolar formal que almeja um atendimento dos alunos que respeita as particularidades culturais dos seus utentes.

Uma das recomendações da consulta pública sobre o plano nacional da educação foi a adopção das "línguas nacionais", línguas da socialização primária de muitos alunos que ingressam no sistema de educação. Essa recomendação visou eliminar a barreira linguística como obstáculo a efetivação da educação dos alunos no sistema de educação, sabendo-se que esta condição foi ou ainda é umas das principais causas do insucesso escolar manifesta na reprovação e no abandono escolar. Refere-se no balanço que o ensino das "línguas nacionais" não é feito, sem, contudo, dizer-se o que esta situação realmente representa na vida escolar dos alunos. Não depreendemos também o que o ensino das línguas nacionais implica. Estar-se-á diante do ensino das línguas nacionais 
como veículo de comunicação a ser aprendido pelos alunos ou a adopção dessas línguas como meio de ensino para que os conteúdos das disciplinas fossem finalmente apreendidos pelos alunos?

A questão das línguas nacionais no sistema de ensino é abordada também por António Filipe Augusto (2013) no seu estudo "Assessing the introduction of the Angolan indigenous languages in the educational system in Luanda”. Augusto diz que o processo da presença das línguas nacionais é condicionado pelo facto de Angola carecer de uma ideologia linguística mais inclusiva e também porque as ações sobre a presença das línguas nacionais no sistema de educação necessitam de uma sustentação legal manifesta na inexistência de documentos que referenciam e orientam a introdução das línguas nativas nas classes da escolarização obrigatória do sistema de educação, ou ainda o seu uso como veículos da educação escolar formal. É a ausência desta normatização que condiciona a mobilização de recursos e a definição de pressupostos para efetivar a presença das línguas nacionais no sistema de educação para criar condições conducentes a garantia do direito de ser educado nos marcos da sua cultura, sendo a língua um destes marcos.

Relativo à ideologia, Augusto pensa que a atual ignora o aspecto multilíngue e multicultural do país, e esta ideologia ao informar a política linguística, produz uma política monolíngue de instrução que não é compatível com a realidade multicultural do país para qual ela é destinada. Buscando a posição do Estado, observamos que a CRA de 2010 determina que a língua oficial da República de Angola é o português (ponto 1, artigo $19 .^{\circ}$ ) e que o Estado valoriza e promove o estudo, o ensino e a utilização das demais línguas de Angola (ponto 2, do artigo 19. ${ }^{6}{ }^{69}$. No sistema de educação, como definido na LBSE de 2001, determina-se que "o ensino nas escolas é efetuado em língua Portuguesa" (ponto 1, artigo 9..$^{\circ}$. Para as línguas nacionais, sem prejuízo a obrigatoriedade do ensino na língua portuguesa, elas, particularmente no subsistema de educação de adultos, podem ser o instrumento de ensino (ponto 3, artigo 9. ${ }^{\circ}$ ) (ANGOLA, 2010a).

${ }^{69}$ Raul C.V. Araújo e Elisa R. Nunes, na "Constituição da República de Angola Anotada, Tomo 1, de 2014, anotam que este artigo é novo nas Constituições em Angola. Dizem os autores que "com este artigo a CRA consagra a Língua Portuguesa como língua oficial da república e dá, igualmente, a língua o estatuto de língua nacional”. 
Mas, devido à necessidade de ajustar o programa nacional Educação Para Todos às demandas dos parceiros, particularmente às da Unesco, a reforma educativa predispôsse a integrar as línguas no ensino. Os relatórios do governo sobre a implementação da reforma e o estudo de Augusto falam na aprovação das línguas kikongo, kimbundo, cokwe, umbundu, mbundu e oxikwanyama para a sua experimentação no sistema, não como meio de ensino, mais como línguas a conhecer. A escolha das mesmas assenta na sua representatividade, número de falantes, que elas têm no território nacional. Pretensão esta contestada por Augusto, por a mesma, por um lado, ser seletiva em relação aos grupos etnolinguísticos que compõem Angola e, por outro, ela não resolver as necessidades de aprendizagem daqueles que, ao não terem a língua portuguesa como língua materna, não são adequadamente atendidos no sistema de educação. Mas a realidade constatada pelo autor mostra que praticamente nada de relevante foi feito para a adopção das línguas nacionais no sistema de educação.

A principal razão é a inexistência de orientações normatizadas em legislação ou programas de governo ou setorial afins. Não houve a concepção de instrumentos normativos para dar corpo à política (AUGUSTO, 2013). Por essa razão chega Augusto a conclusão de que existe uma fraqueza legal nos fatores que eventualmente podem dar corpo à política linguística.

Outro fator realçado são as condições concretas para operacionalizar a implementação deste aspecto da política da educação. Como fator que sobressai, constata-se que não há programas, no âmbito da política de formação de professores, realizados nos institutos médios e superiores, de formação de professores para darem corpo ao trabalho pedagógico requerido. O processo de experimentação está a ser conduzido por pessoas não devidamente habilitadas para o efeito. Daí existirem, por exemplo, limitações linguísticas não apenas nos alunos, como nos próprios professores.

Há também o facto de ao existirem materiais didáticos, como os manuais para sustentarem o processo pedagógico. Houve a tentativa das autoridades educativas de produzirem manuais para as línguas selecionadas. O maior percalço foi a questão da normatização das línguas nacionais. Para a língua kikongo, por exemplo, existem 13 variantes da mesma. Como os manuais foram elaborados sem respeitarem esta condição, 
cada consultor contratado para a edição dos manuais corrigia-os em função da variante do seu domínio. As regras da escrita também induziram a disputas sobre a grafia correta de muitas palavras. A não mobilização da inteligência local em torno do programa de valorização e promoção das línguas nacionais esvaziou as declarações formais inseridas na CRA de 2010 (ANGOLA, 2010a) e na LBSE de 2001(ANGOLA, 2001a).

\subsection{Ensino especial}

O ensino especial é formalizado como modalidade de ensino no sistema da educação pela LBSE, concretamente no seu artigo 43, que o define como

[...] uma modalidade de ensino transversal, quer para o subsistema de ensino geral, como para o subsistema da educação de adultos, destinada a indivíduos com necessidades educativas especiais, nomeadamente deficiente ${ }^{70}$ motores, sensoriais, mentais, com transtornos de conduta e trata da prevenção, da recuperação e de integração socioeducativa e socioeconômica dos mesmos e dos alunos superdotados (ANGOLA, 2001a).

Por razão desta, o sistema de educação acrescenta aos já definidos como objetivos do ensino geral outros específicos para orientar o ensino especial, respectivamente:

a) desenvolver as potencialidades físicas e intelectuais reduzindo as limitações provocadas pelas deficiências;

b) apoiar a inserção familiar, escolar e social de crianças e jovens deficientes ajudando na aquisição de estabilidade emocional;

c) desenvolver as possibilidades de comunicação;

d) desenvolver a autonomia de comportamentos a todos os níveis em que esta se possa processar;

e) proporcionar uma adequada formação pré-profissional e profissional visando a integração na vida ativa;

f) criar condições para o atendimento dos alunos superdotados.

\footnotetext{
${ }^{70}$ Nesta e noutras citações da Lei, o termo "deficiente" deve ser entendido como pessoas/crianças/jovens com limitações. Usamos este termo por considerá-lo menos estigmatizante, uma vez que as limitações são comuns nos humanos.
} 
Essa orientação do ensino especial propõe-se a alterar a abordagem feita às necessidades especiais de aprendizagem na anterior política. A Circular n. 56, de 19 de outubro de 1979, (ANGOLA, s.d.) do MED, orientou a criação de condições "mínimas indispensáveis" para o funcionamento de escolas para educar a população com necessidades educativas especiais. Em 1980, via Decreto n. 40/80, (ANGOLA, s.d.) foi aprovado o Estatuto Orgânico do MED, cujo artigo 17 determinava a criação do departamento nacional para o ensino especial. O resultado destas ações se resumiu no atendimento de crianças com limitações visuais e as com limitações auditivas. A abordagem do atendimento das crianças com limitações mentais passou a merecer atenção no princípio da década de 1990. O atendimento destas crianças era feito num ambiente segregado. As mesmas eram confinadas em turmas em função das suas limitações. Elas eram, desde cedo, deslocadas da realidade social e "acostumadas" a uma condição diferenciada e excludente.

A Declaração de Salamanca (Espanha, 1994) adoptada pela Conferência Mundial sobre as necessidades educativas especiais alterou a abordagem do sistema sobre a educação especial por ter definido alguns princípios sobre esta modalidade de educação, princípios esses a observar pelos países subescritores. O Projeto 534/ANG/10 (ANGOLA, s.d.) encarregou-se de promover oportunidades educativas para crianças com necessidades especiais, resultando na integração de várias crianças na escola pública, quer em salas especiais como em salas comuns, onde foram integradas e partilhavam o espaço e as vivências com outras crianças. Esta inserção foi um processo gradual que começou com 3 províncias (Luanda, Benguela e Huila) e alargou-se para mais províncias (Huambo, Cabinda e Bié).

Verifica-se, desde então, o crescimento do atendimento no ensino especial. Esse crescimento deve-se entre vários fatores ao aumento de escolas especiais/centros de recurso que passaram de 5 escolas a 14, o crescimento de salas integradas/inclusivas para 687 no período 2002-2011, mas também pelos programas e projetos desenvolvidos pelo Ministério da Educação, dos quais convém citar a campanha de informação e sensibilização da população com relação à educação de crianças adolescentes e jovens com necessidade educativa especial, as ações de capacitação em serviço dos professores e gestores da educação especial, tanto ao nível nacional e provincial, e a distribuição de 
materiais didáticos e equipamentos específicos para os alunos com necessidades educativas, dentre outros.

Segundo dados do MED (ANGOLA, s.d.), o aumento de alunos nesta modalidade foi de 7.406 em 2002 para 23.193 em 2011. É notório o crescimento, durante os dois últimos anos escolares, nas províncias do Namibe, com $116 \%$; na Lunda Sul, 124\%; no Cunene; com 114\%. No índice de paridade do gênero, dados mostram que, em 2002, este índice era de 0,86, tendo passado para 0,90 em 2011. A diferença entre rapazes e raparigas tem diminuído apesar de existir na modalidade mais rapazes do que raparigas.

Relativamente ao número de alunos por limitação, o MED reporta que se verificou em 2002 uma grande concentração de alunos na categoria de retardo no desenvolvimento psíquico (RDP), com 23,4\%; na limitação auditiva, com 20,8\%; na limitação mental, com 17,8\%. Contudo, em 2011 a dinâmica foi diferente com a predominância dos alunos com deficiência auditiva, com 25\%; deficiência intelectual; com 19,2\%; transtornos globais no desenvolvimento, com 15,2\%. Houve um salto quantitativo da limitação auditiva, de 10 para 25\%, que o MED justifica com a introdução do dicionário da Língua Gestual de Angola no sistema, o que permitiu maior acesso ao currículo de alunos com limitações (ANGOLA, s.d.).

Em 2002, as províncias com maior número de alunos por limitações foram: Luanda, com 15,8\%; Kwanza sul, com 19,2\%; demais províncias, com um valor percentual inferior a 10\%. Contudo, as limitações mais predominantes nas províncias acima referidas foram: a mental, com 53,3\%; a auditiva, com 30\% em Luanda. Enquanto na província do Kwanza Sul, os índices foram de 21,3\% para a limitação auditiva e 17,5\% para o transtorno de conduta. Importa referir que em algumas províncias há um número significante a considerar, como é o caso de Benguela, com 64,6\% de retardo de desenvolvimento psíquico (RDP), e do Bié, com 50\% de RDP dentre a sua população no ensino especial (ANGOLA, s.d.). 
Com relação à distribuição de alunos por níveis de ensino ${ }^{71}$, a modalidade contou em 2011 com 15.379 (66,3\%) no primário; 6.658 (28,7\%), no I ciclo do Ensino Secundário; 1.156 (5\%), no II ciclo do ensino secundário. De considerar que há um desajuste na pirâmide, pois há grande concentração de alunos com necessidades educativas especiais no ensino primário que vão diminuindo à medida que aumenta os níveis de ensino. Podem ser causas: a desistência, a reprovação, ou a insuficiente oferta para os níveis subsequentes. Sobre as taxas de aproveitamento em 2011, registraram-se $56,3 \%$ de alunos aprovados; $23,7 \%$ de reprovados e $20 \%$ de abandono/desistência, segundo dados do MED (ANGOLA, s.d.). No ensino secundário, I e II ciclos, as taxas de aprovação estão situada entre $61 \%$ a $72 \%$; a taxa de reprovação está acima de $15 \%$, com maior incidência no II ciclo do ensino secundário (27,0\%); a taxa de desistência calculase em cerca de $11 \%$. Para o MED, esse fraco aproveitamento no ensino primário pode estar ligado a problemas de acesso aos currículos por parte de alunos com necessidades educativas especiais e ao nível de preparação de professores cuja maioria não tem formação adequada para trabalhar nesta modalidade de ensino, alguns, inclusive, nas turmas regulares do ensino de base.

Além dessa perspectiva do acesso à educação desses alunos há, também, a questão da legislação que vai se atualizando para firmar formalmente o compromisso do Estado. Pela CRA, 2010, o Estado reforça o compromisso com o atendimento dos cidadãos com limitações. Inserido no capítulo "Direitos e Deveres Econômicos, Sociais e Culturais", o artigo 83, dentre outros declara que:

\footnotetext{
Os cidadãos com deficiência gozam plenamente dos direitos e estão sujeitos aos deveres consagrados na Constituição, sem prejuízo da restrição do exercício ou do cumprimento daqueles para os quais se encontrem incapacitados ou limitados (ponto 1);

O Estado adopta políticas visando a sensibilização da sociedade em relação aos deveres de inclusão, respeito e solidariedade para com os cidadãos com deficiência (ponto 3);

O Estado fomenta e apoia o ensino especial e a formação técnico-profissional para os cidadãos com deficiência (ANGOLA, 2010a, ponto 4).
}

\footnotetext{
${ }^{71}$ Apesar do estudo estar delimitado entre a primeira e a sexta classe do ensino primário, apresentamos aqui dados de outros ciclos para ilustrar a progressão dos alunos desta modalidade no sistema.
} 
Apercebe-se que os valores e os princípios coerentes com o direito à educação e as várias formas de efetivá-los, como expressos nos instrumentos internacionais, têm se manifestado na política pública em educação em Angola. No plano formal há um crescente aperfeiçoamento da questão dos direitos, se compararmos as diversas leis constitucionais. No próprio sistema de educação, há também uma série de ações que se vão aliando à necessária efetivação do direito da educação. Mas, constata-se também que muito dos fundamentos dessas ações nem sempre evocam a necessidade de conceber a educação como direito. Por essa razão, buscamos compreender algumas ideias relativas aos princípios deste direito: origem das mesmas e os autores que as tenham eventualmente induzido na política educacional.

\subsection{O financiamento da educação pública}

O financiamento da educação pública é essencialmente garantido pelo Orçamento Geral do Estado que é pela Lei do Orçamento ( Lei n. 2/13) é "o principal instrumento da política econômica e financeira do Estado Angolano". Destinado a financiar a educação, o orçamento para este fim é prioritariamente destinado ao Ministério da educação que assume a natureza de unidade orçamental.

Na condição de unidade orçamental, o MED é definido como um órgão do Estado a quem foi consignado a dotação orçamental própria. Ao MED, por isso, compete ao abrigo do artigo 3 do decreto n. 73/01, entre outras atribuições, "coordenar, gerir, distribuir e controlar os créditos orçamentais e os recursos financeiros destinados a todos os órgãos dependentes e/ou sob sua jurisdição". Depreendemos deste modo, que o OGE é a principal fonte do financiamento dos custos da educação no sistema público.

Nos parâmetros da Lei do Orçamento, o OGE é um instrumento em que se reflete anualmente o exercício do governo com vista a materialização da política econômica do governo em diversos exercícios financeiros. O OGE proporciona e fixa os limites das despesas; respeitando os princípios da unidade, universalidade e anuidade. O principio da unidade torna o OGE unitário, inscrevendo todas as receitas e despesas de todos os 
serviços, institutos e fundos autônomos, bem como a segurança social. Por sua vez, o princípio da universalidade, "considera o orçamento como expressão de todas as disponibilidades e necessidades do Estado, incluindo os recursos oriundos de outras fontes" (Da COSTA ET ALLI, 2001, p. 134). E o princípio da anualidade deve fazer coincidir o ano econômico com o ano civil.

Consagra-se pela Lei 9/97 que as receitas do OGE são constituídas por todas as receitas públicas do Estado e dos seus órgãos dependentes e o tributo (os impostos, taxas e contribuições financeiras) (ANGOLA, 2005). Quanto as despesas orçamentais, a referida lei define-as como todas as despesas públicas cometidas pelo Estado ou aos organismos que dele dependem. As despesas obedecem às seguintes classificações:

- Institucional: engloba o conjunto de unidades orçamentais.

- Funcional: programática tem por escopo vincular a despesa orçamental às ações e aos objetivos e metas governamentais, respeitando o Plano Nacional.

- Económica: compreende as despesas correntes destinadas à manutenção ou operação de serviços e as de capital destinadas à formação ou aquisição de ativos permanentes, à amortização da dívida, à concessão de financiamento ou à construção de reservas, bem como às transferências realizadas com igual propósito.

Sendo o OGE o principal instrumento e a principal fonte de receitas e a definição das despesas do Estado e das suas instituições, é pertinente olharmos para os procedimentos para a sua elaboração. Esse olhar ajuda-nos a compreender os processos de definição dos recursos das instituições públicas. Particularizamos, neste caso, as ações que visam essencialmente o financiamento da educação, vamos nos pontos a seguir descrever os papeis reservados aos intervenientes da elaboração do OGE.

Quanto aos intervenientes e os e os respectivos papeis, regulamenta-se que a elaboração da proposta orçamental faz-se com base em instruções publicadas pelo Ministério das Finanças (MINFIN). Essas atribuições, no processo de elaboração do OGE, estão fundamentadas com mais precisão no Estatuto Orgânico do referido Ministério. (ANGOLA, 2005). O artigo 2 do Capitulo I deste estatuto reservado as 
atribuições do MINFIN diz na alínea c) do ponto 1 que se reserva ao MINFIN a elaboração e a coordenação da programação financeira da execução do orçamento. $\mathrm{Na}$ alínea b) do mesmo ponto, acresce-se que o MINFIN elabora, executa e controla o OGE tendo em conta os objetivos fixados pelo governo. O ponto III do mesmo artigo reserva as atribuições relacionadas com a elaboração de normas e métodos a que deve obedecer a preparação e execução do OGE (alínea a)).

Ainda sobre as atribuições do MINFIN na elaboração do OGE, o artigo 19 (ANGOLA, 2005) reserva a uma direção dos serviços executivos, a direção nacional do orçamento, neste caso, a responsabilidade de "elaborar estudos, pareceres, e propostas sobre a política orçamental e diretrizes para a elaboração do OGE" (alínea a)), e "prestar o conveniente apoio técnico às unidades orçamentais de harmonia com as necessidades do processo orçamental” (alínea i)). Os dispositivos legais acima transcritos apresentam o âmbito de responsabilidade e papel do MINFIN na elaboração do OGE. Todavia, sendo este processo de elaboração um processo participado - isto é, o MINFIN trabalha com as unidades orçamentadas para a definição dos orçamentos das respectivas áreas-, vamos buscar o papel que o MED desempenha na definição do orçamento do seu sector.

No decurso do processo de elaboração da proposta do OGE, o MED obedece às modalidades definidas para todos os serviços da administração pública. Deste modo, centra-se o processo de elaboração entre outros aspectos sobre a necessidade de visar as diretrizes do programa do Governo. A educação em particular procura dotar o projecto do orçamento com aportes que incidem sobre os objetivos definidos na política educativa do país. No MED, o projeto de orçamento é elaborado obedecendo o seguinte: a Secretaria Geral via Departamento de Administração e Gestão do Orçamento (DAGO) elabora a proposta do orçamento para as despesas de funcionamento. Para as despesas de investimento, esta responsabilidade recai para o Gabinete de Estudos, Planeamento e Estatística (GEPE).

Da Costa e alli (2003) descreve do modo seguinte o comportamento dos diferentes atores do MED no processo de elaboração da proposta do orçamento: a Secretaria Geral é o órgão encarregue pelo orçamento para as despesas recebe do MINFIN via Direção Nacional do Orçamento as instruções e documentos para a 
elaboração do orçamento de funcionamento e distribuir às diferentes unidades gestoras sob dependência da unidade orçamental - MED. Por sua vez, o GEPE recebe do Ministério do Plano (MINPLAN) as instruções necessárias para a elaboração do orçamento de investimento. As propostas de orçamento são enriquecidas com as propostas de programa das direções nacionais, propostas estas que levam em consideração as linhas mestras definidas pelo programa do MED. Compete ao conselho de direção do MED apreciar e aprovar o projeto de orçamento e remete-lo ao MINFIN. Após o envio das propostas de orçamento ao MINFIN, o MED, na qualidade de proponente do orçamento, inicia negociações com o MINFIN e o MINPLAN, na qualidade de órgão reitores da política econômica e financeira do país.

A nível provincial, o processo de elaboração da proposta do orçamento é conduzido pela direção provincial de educação e em certos casos por escolas com o estatuto de unidades gestoras que propõem aos Governos Provinciais as suas necessidades sobretudo para o orçamento de funcionamento. $O$ orçamento de investimento toma um percurso diferenciado para os ajustar as competências definidas na lei 11/95 (ANGOLA, 2005). A assumpção do processo de elaboração da proposta orçamental pelas direções provinciais de educação resulta do processo de descentralização administrativa dos serviços públicos definidos na Lei $17 \backslash 99$ (ANGOLA, 2001). Ao abrigo desta lei, as direções provinciais de educação dependem orgânica, administrativa e funcionalmente do governo da província. Como atribuições, estes órgãos dos governos provinciais respondem "por todas as questões em termos de execução relacionadas como o Ensino de Base" (ANGOLA, 2001, p.96). É também atribuição destes órgãos a nomeação e contratação de pessoal docente e não docente para os respectivos estabelecimentos de ensino e a gestão dos estabelecimentos do ensino primário.

Este processo de elaboração da proposta culmina com reuniões entre o MED, o MINFIN e MINPLAN. Estas reuniões são principalmente de caráter político, nas quais participam os serviços técnicos dos referidos ministérios. Como resultado das negociações, determina-se o teto financeiro máximo destinado ao sector. O MED e as distintas direções provinciais são depois solicitados a apresentarem as suas prioridades em conformidade com os recursos aprovados nestas reuniões. Para a preparação do 
orçamento de investimento, observa-se geralmente os mesmos procedimentos, excetuando o fato de as necessidades de recursos financeiros para a execução das ações contidas no PIP (programa de investimento publico) ser solicitada e negociada com o MINPLAN (Da Costa, 2003).

Após a aprovação do orçamento, as unidades orçamentais tornam-se as responsáveis por transmitir aos órgãos dependentes os créditos aprovados. Estes créditos constituem o orçamento de funcionamento que integra fundamentalmente as despesas com o pessoal e as despesas com bens e serviços. As despesas com pessoal, que são uma prioridade em relação às outras despesas, resumem-se essencialmente na remuneração do pessoa docente, administrativo e serviço. Para além da natureza das despesas, a distribuição dos recursos por ciclos de ensino e regiões é um dos atributos do sistema de financiamento de educação. Este atributo ajuda a compreender as fórmulas elou os métodos discricionários utilizados para distribuir os fundos e recursos entre regiões e instituições.

Durante o processo de distribuição dos recursos, o MED, na condição de estrutura central, como resultado da política de descentralização administrativa, tem o seu papel de órgão orientador e definidor de normas e processos limitado. Esta limitação do papel deve-se ao fato de a afetação dos créditos orçamentais ser pelo MINFIN que via direção nacional do orçamento, os remete as respetivas unidades orçamentais. Estas unidades, por sua vez, fazem a distribuição dos recursos financeiros às instituições educativas. Nesta situação, nas palavras de da Costa, 2001:

para a distribuição dos recursos, geralmente são tidas em consideração os diferentes indicadores educativos ou prioridades da educação. As decisões de atribuição de recursos são tomadas sobretudo por critérios que se fundamentam na base de indicadores macroeconômicos (DNO) e no subjetivismo e sensibilidade das autoridades locais (Governos provinciais). (p. 153)

Para além dos fundos do Estado, existem outras fontes de financiamento da educação pública. Por exemplo, as organizações não governamentais (ONGs) participam nos custos da educação de diferentes formas. As suas ações neste âmbito incidem essencialmente nas contribuições financeiras, construção ou reabilitação de 
infraestruturas escolares e apoio em material didático. Estas ações desenvolvem-se basicamente nas zonas rurais e nas do perímetro urbano. As organizações internacionais como o Banco Mundial e o Banco Africano de Desenvolvimento são financiadores externos relevantes. As suas participações incidem sobre grandes projetos para o desenvolvimento do sistema de educação, com as ações de construção e reabilitação de escola, fornecimento de equipamento escolares, manuais escolares, e o reforço de capacidade institucional (Da Costa et alli, 2001). Somados à estes organismos, instituições como as Agencias das Nações Unidas, Instituições elou Programas de Desenvolvimento \Cooperação de países com os quais Angola mantém acordos dão o seu contributo no financiamento da educação.

Depreende-se que o sistema de educação em Angola é essencialmente de caráter público, sendo por isso o seu financiamento da responsabilidade do Estado. Este financiamento processe-se nos termos definidos pelas respectivas leis do orçamento geral do Estado. Quando confrontado com as modalidades de financiamento na perspectiva de Barro (1999), o modelo de financiamento do sistema de educação em Angola apresenta característica do modelo centralizado da Europa continental. Neste modelo existe uma predominância do governo central na geração de fundos para a educação. Existe também a omnipresença do governo central nas questões como a contratação e o pagamento do pessoal docente e o controlo dos fundos para a educação.

No sistema de educação em Angola constata-se, a semelhança do modelo centralizado, a assumpção do grosso do financiamento da educação pelo OGE, e a atribuição do estatuto de servidores públicos aos professores e aos demais funcionários da educação. Finalmente, apesar do seu engajamento no processo de elaboração da proposta do orçamento para o sector, o governo central via o MINFIN determina, na verdade, os recursos a alocar aos níveis, regiões, em fim, à todo sistema da educação. Os critérios para esta tomada de decisão, por serem por norma políticos e subjetivos, constituem-se num obstáculo a execução de uma agenda da educação que responda as demandas da educação como direito. 
O financiamento da educação tem sido considerado como um dos principais fatores que comprometem os programas de desenvolvimento dos sistemas de educação nos países em desenvolvimento, sendo a África subsaariana uma das regiões em que este fenômeno se manifesta. Por isso, mostramos por intermédio das dotações do OGE a programação financeira aprovada pelo governo como um dos instrumento conducentes a efetivação da política da educação .

Quanto aos valores destinados à educação pelo OGE, apresentamos na Tabela ${ }^{72}$ 19 o valor global para a educação, e deste mostramos a percentagem reservada ao ensino primário, nível de escolarização obrigatória, e a distribuição desta pelos diferentes programas concebidos para este nível da escolaridade, e também a frequência destes programas ao longo do período em estudo.

\footnotetext{
${ }^{72}$ Os dados da tabela cobrem o período compreendido entre 2001 e 2013. Cobre o mesmo por ter sido aprovado em 2001 a LBSE que define a reforma educativa, e também por ser este o período analisado pelo estudo. Acresce-se o facto de que no ano 2002 indicar o fim do conflito armado, dando vazão as atividades do programa de reconstrução nacional e também da redefinição das prioridades do programa de governo com ênfase nas políticas sociais e das e nas conducentes ao crescimento econômico.
} 
Tabela 19 Orçamento da educação e dos respectivos programas em \%

\begin{tabular}{|c|c|c|c|c|c|c|c|c|c|c|c|c|c|c|}
\hline & & 2001 & 2002 & 2003 & 2004 & 2005 & 2006 & 2007 & 2008 & 2009 & 2010 & 2011 & 2012 & 2013 \\
\hline & Educação & 5,06 & 5,19 & 6,24 & 10,47 & 7,14 & 3,82 & 5,61 & 7,91 & 7,90 & & 8,18 & $\mathbf{8 , 3 7}$ & 8,83 \\
\hline & $\begin{array}{l}\text { Ensino } \\
\text { Primário }\end{array}$ & 1,04 & 0,38 & 0,78 & 0,49 & 0,59 & 1,39 & 0,40 & 1,45 & 1,27 & & 5,66 & 5,66 & 4,77 \\
\hline \multirow{11}{*}{ 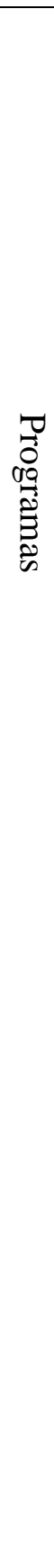 } & Salários & $0,00^{*}$ & - & & & & & & & & & & & \\
\hline & $\begin{array}{ll}\text { Construção } & \mathrm{e} \\
\text { rehab. } & \text { de } \\
\text { escolas } & \end{array}$ & 0,11 & 0,17 & 0,62 & 0,35 & 0,52 & 1,03 & 0,01 & $1,51^{\mathrm{a}}$ & & & & & \\
\hline & $\begin{array}{l}\text { Aquisição de } \\
\text { Equip. e mat. } \\
\text { Escolar }\end{array}$ & 0,03 & 0,01 & & & & & & & & & & & \\
\hline & $\begin{array}{l}\text { Investimento } \\
\text { públicos }\end{array}$ & 0,43 & & & & & & & & & & & & \\
\hline & $\begin{array}{l}\text { Gastos } \\
\text { administrativos }\end{array}$ & 0,56 & & & & & & & & & & & & \\
\hline & $\begin{array}{l}\text { Equip. e } \\
\text { apetrechament } \\
\text { o de escolas }\end{array}$ & & 0,04 & 0,12 & 0,05 & 0,00 & 0,05 & 0,01 & 0,05 & & & & & \\
\hline & $\begin{array}{l}\text { Desenvolvimen } \\
\text { to Ensino } \\
\text { Primário }\end{array}$ & & 0,08 & 0.04 & 0,04 & 0,06 & & & & $0,20^{b}$ & & $0,93^{b}$ & $0,92^{b}$ & $0,10^{b}$ \\
\hline & $\begin{array}{l}\text { Erradicação do } \\
\text { Analfabetismo }\end{array}$ & & 0,08 & & & & & & & & & & & \\
\hline & $\begin{array}{l}\text { Escola para } \\
\text { todos }\end{array}$ & & & & 0,04 & 0,01 & & & & & & & & \\
\hline & $\begin{array}{l}\text { Capacitaço dos } \\
\text { rec. Humanos }\end{array}$ & & & & & & 0,01 & & & 0,14 & & & & \\
\hline & \begin{tabular}{lr}
\multicolumn{2}{l}{ Assistência } \\
social \\
alunos \\
escola
\end{tabular} & & & & & & 0,00 & & 0,14 & 0,22 & & 0,10 & 0,10 & \\
\hline
\end{tabular}




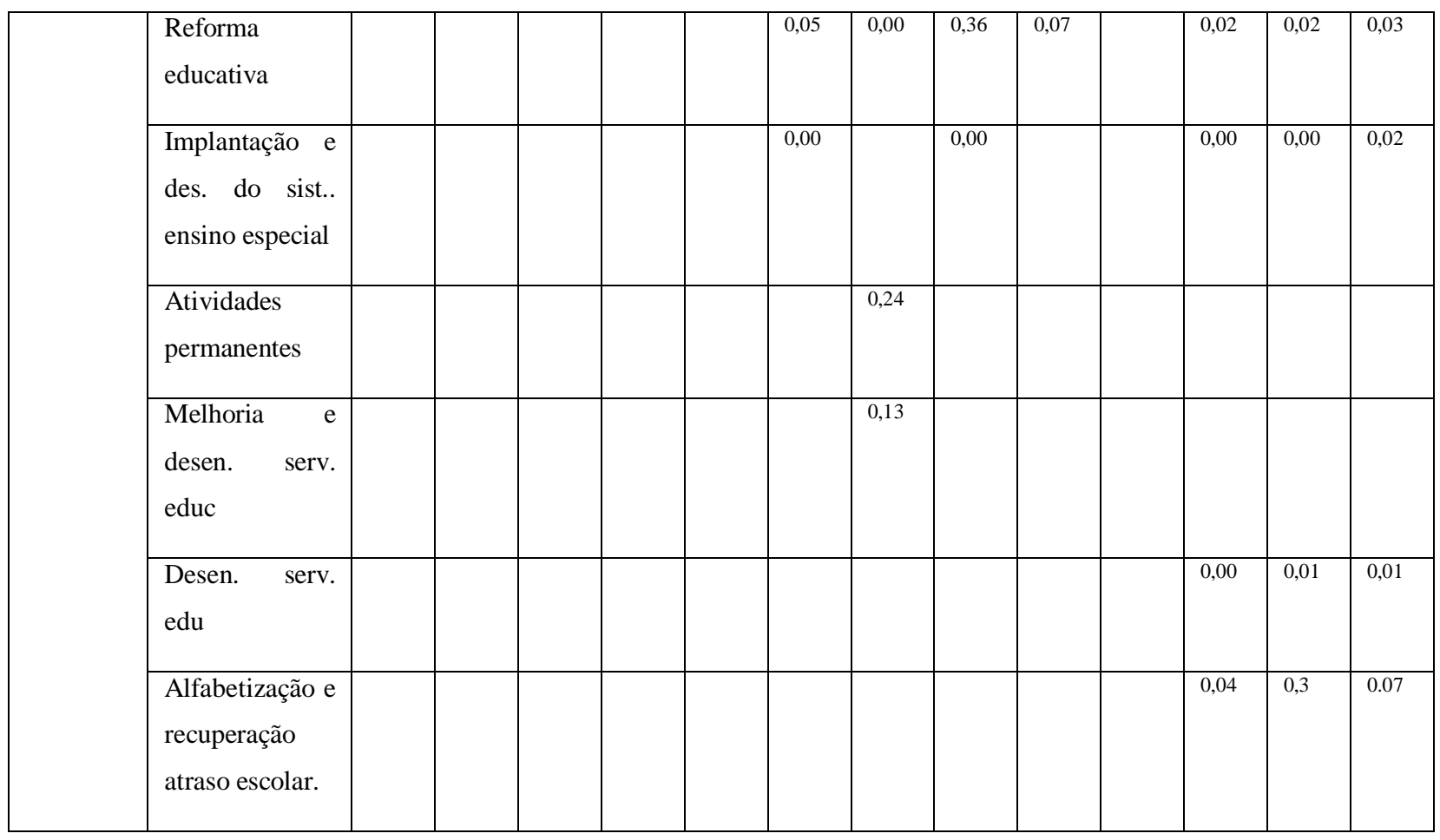

Fonte: minfin.gov.ao

* Valores inferiores a $0,01 \%$

a Apresentação geral- pode incluir mais do que um nível de ensino.

A - Valores excluídos por incluírem outros níveis e serviços

b combinado com o secundário

A tabela acima mostrada mostra a tendência do crescimento do orçamento geral atribuído à educação, salientando-se no quadro a quase duplicação do valor nos anos 2003-2004. Mas, este crescimento não significa simultaneamente um acréscimo do valor para o ensino primário, pelo contrario, há uma redução aproximada de $40 \%$ dos valores atribuídos à este nível nesses anos. Salienta-se igualmente a natureza dos programas aos quais eram destinados as maiores percentagens dos fundos providos à educação primária.

Entre 2001 e 2008, período em que estes programas são citados, a questão das infraestrutura físicas (construção e reabilitação de escolas; equipamento e apetrechamento de escolas) constituíram-se nos princípios destinos das verbas alocadas ao ensino primário. Entretanto, verifica-se principalmente, no período 2009-2013, o crescimento dos valores para os programas de "desenvolvimento do ensino primário". Mas, a ausência de uma caracterização deste "desenvolvimento" não nos permitiu identificar as atividades 
para as quais eram estes valores destinados. O mesmo acontece com a referencia do programa "reforma educativa". Como a reforma educativa previa varias atividades distribuídas entre as que visavam o acesso e as que se destinavam ao atendimento dos alunos uma vez no sistema, a ausência desta caracterização dificulta a identificação e também a compreensão da prioridades dos programas nas atividades relativas a garantia do direito à educação.

No período 2006-2012, o OGE contempla programas definidos como "assistência social dos alunos na escola”. Acreditamos que este programa contempla a implementação da "merenda escolar" identificada nos princípios da reforma educativa como fator para melhor o desempenho dos alunos escola e também da redução dos índices de abandono escolar. O Ensino especial aparece de igual modo como programa com orçamento próprio após o ano de 2006, apesar de o mesmo estar formalizado como modalidade de ensino na LBSE de 2001.

Se comparados os diferentes níveis do sistema de educação (primário, secundário e superior) (Tabela 20), o ensino primário é-lhe atribuída maior dotação do orçamento para educação. Entendemos que esta condição esta relacionada com o facto do ensino primário ser o nível com maior índice da população atendida, que podem ser tomados como indicadores do financiamento para o acesso assente na crença da universalização do ensino primário.

Tabela 20 Orçamento da educação e dos respectivos níveis em \%

\begin{tabular}{|c|c|c|c|c|c|c|c|c|c|c|c|c|c|}
\hline & 2001 & 2002 & 2003 & 2004 & 2005 & 2006 & 2007 & 2008 & 2009 & 2010 & 2011 & 2012 & 2013 \\
\hline Educação & 5,06 & 5,19 & 6,24 & 10,47 & 7,14 & 3,82 & 5,61 & 7,91 & 7,90 & & 8,18 & $\mathbf{8 , 3 7}$ & $\mathbf{8 , 8 3}$ \\
\hline Ensino Primário & 1,04 & 0,38 & 0,38 & 0,49 & 0,59 & 1,39 & 0,40 & 1,45 & 1,27 & & 5,66 & 5,66 & 4,77 \\
\hline Ensino Secundário & 0,51 & 0,47 & 0,47 & 0,42 & 0,55 & 0,72 & 0,20 & 2,36 & 1,69 & & 0,95 & 1,09 & 1,37 \\
\hline Ensino superior & 0,96 & 0,24 & 0,74 & 0,68 & 0,66 & 0,38 & 0,52 & 0,72 & 0,97 & & 0,94 & 0,85 & 1,24 \\
\hline
\end{tabular}

Fonte: minfin.gov.ao 


\section{A POLÍTICA EDUCACIONAL FACE ÀS SUAS ORIGENS E SEUS FINS}

Em sua obra Reforming education (2001), Benjamin Levin diz que as políticas públicas que resultam de reformas educativas incentivadas pelas mudanças dos propósitos sociais prescritos para a educação têm a sua gênese num processo que comporta vários estágios, os quais se deslocam da "identificação de um problema à identificação ou adopção de estratégias particulares e as questões de implementação e dos resultados" (LEVIN, 2001, p. 19).

Sendo a reforma educativa, ainda segundo o autor, programas de mudanças educacionais sob direção e iniciativa dos governos, o seu mando é geralmente assumido pelo aparato político do governo, e não pelos educadores. Contudo, a educação é um bem social cujos benefícios são do usufruto não apenas do indivíduo, que a ela é diretamente submetido, como também de outros atores sociais em função de sua relação com o indivíduo educado. É na educação que a própria sociedade encontra mecanismo para recriação de sua existência material e, também, mecanismo de abordagem dos novos desafios que se apresentam às sociedades. Para melhor compreensão das ideias que circulam nos vários estágios da reforma, a atuação dos diferentes atores, e a distância ou a proximidade entre as ideias iniciais e a proposta final, elegemos retomar os quatro elementos ou fases dos processos da reforma definidos por Levin. Essas fases são: "as origens, a adopção, a implementação e os resultados” (LEVIN, 2001, p. 19).

Para o propósito deste estudo, nos pontos que se seguem, centramos a análise das fases "das origens e da adopção" por serem as que produzem evidências sobre as ideias propostas nos processos de elaboração de políticas públicas, bem como a natureza e a relevância dos diversos atores que participam nesses processos. Buscamos assim, neste capítulo, analisar a política de educação quanto às suas origens e seus fins enunciados, considerando a discussão sobre essa política como mecanismos para efetivar direitos inerentes à educação. 


\subsection{As origens das políticas educacionais}

Ao abordar as origens, Levin (2001) realça que o foco nessa fase da reforma incide sobre as fontes proponentes das reformas inicialmente enunciadas pelos: governo, vários atores, forças que dão origem aos ideais das reformas e filosofias sobre a educação, as quais permeiam as reformas propostas. Busca-se essencialmente compreender a razão de as adoptadas se efetivarem em detrimento das outras e, também, as relações de influência entre os vários atores, isto é, a razão de as ideias de alguns atores sobressaírem em detrimento das dos outros, dado que "em situação alguma pode-se compreender as origens da reforma da educação sem prestar-se atenção aos atores individuais, as fontes de influência e os processos políticos, bem como as ideias subjacentes" (LEVIN, 2001, p. 114).

É na necessidade da compreensão da origem das políticas que Page (2006) também se debruça. $\mathrm{O}$ autor alega que as políticas podem refletir uma variedade de intenções e de ideias ou, então, resultados não intencionais ou imprevistos da ação prática de profissionais ou das rotinas de burocratas. Essas ideias, práticas e intenções, continua Page, podem ser influenciadas ou moldadas por várias circunstâncias, que vão desde sugestões específicas e imediatas às crenças gerais, fundadas em verdades universais.

Para explicar a origem de programas particulares e como os mesmos se transformam em agenda política, Levin socorre-se de Kingdon (1993), que vê as agendas políticas como resultado da interseção de três processos, nomeadamente, os eventos políticos, o reconhecimento dos problemas e as propostas políticas. É nessa perspectiva que

Uma determinada questão assume um lugar de destaque na agenda política somente quando as três correntes [acima referenciadas] se reúnem de modo que haja um reconhecimento político de algo como um problema, uma oportunidade política de se tomar uma ação, e como uma proposta aceitável em como a ação será conduzida. (LEVIN, 2001, p. 65).

O reconhecimento do problema, continuando com Kingdon (1993), relaciona-se com a percepção que confere a uma determinada questão da política a condição de um problema e que, por isso, requer a atenção do governo. Para além da capacidade interna 
do governo em exercitar o reconhecimento de um problema, o mesmo governo pode estar sujeito às influências externas. Por se acreditar que a educação serve múltiplos propósitos sociais, vários agentes da sociedade buscam exercer a sua influência e, com isso, moldar a agenda de governo sobre a educação, o que motiva as agendas do governo a estarem sujeitas às agendas políticas de uma grande variedade de lobbies (LEVIN, 2001). EsSa influência externa é exercida por agentes, que designamos de origem local, em representação de grupos profissionais, de pais, económicos, e de outros interesses na área da educação. Podemos também incluir nesses grupos de origem local os partidos políticos.

Contudo, para além desses mencionados, atuam também, como influência externa nos processos de políticas, os movimentos transnacionais que induzem o que a literatura denomina de policy borrowing. Wiseman e Baker (2005) sugerem que esse processo, que expande a internacionalização dos processos de elaboração de políticas públicas em nações individuais, deve-se à crescente utilização de padrões internacionais para avaliar a qualidade da educação interna num determinado país, cujos resultados, se positivos, conferem aos governos o rótulo de boas práticas de governação. É ainda nessa perspectiva de padrões internacionais que se desenvolve o que Baker (2009) designa de conceito comum sobre os inputs da educação e a métrica dos resultados das aprendizagens que sustentam as comparações cross national dos respectivos resultados. É esse ideal de governação que, associado aos ideais de desenvolvimento nacional conferidos pela educação, sustenta o pensamento da relevância das comparações internacionais como fator vital para a concepção das políticas de educação em muitos países (WISEMAN; BAKER, 2005).

Em regra, nas sociedades, a política pública é um processo racional limitado, afirmam os autores. É tão racionalizado ao ponto de existirem de antemão problemas identificados às respectivas soluções e às estratégias de implementação. No caso específico da educação,

[...] ao contrário, todo processo de elaboração da política da educação é poroso - aberto às influências externas em graus variados [...] estando assim à mercê das forças externas, como o pensamento comum e universal sobre de que maneira a educação deveria funcionar em todos os países. (WISEMAN; BAKER, 2001, p. 4). 
Baker (2009) afirma que, na sua fase inicial, a compreensão que se desenvolve sobre as ideias presentes na elaboração das políticas é explicitamente nacional. Porém, apesar de muitas das questões usadas nas políticas serem de relevância local, as mesmas têm praticamente as suas raízes em pensamentos globais, sustentados por uma cultura comum sobre educação, e transformados em instrumento global da ação sobre a educação. Por isso, “o que aparenta ser uma questão candente da política da educação ao nível local ou nacional é, quase sempre, um produto de tendências alargadas no âmbito da educação global" (BAKER, 2009, p. 958).

A internacionalização das políticas é incentivada pelas ideias ou conceitos que, ao terem respondido aos desafios em outros países, são adoptadas por empréstimo (policy borrowing) para as ideias locais de um determinado país para lidar com os seus desafios. As ideias, entende-se aqui, como em Kingdon (1993), referem-se às crenças sobre as preferências dos objetivos das políticas e às estratégias adequadas para visar esses objetivos. À medida que essas "ideias e conceitos se alastram, elas ganham gradualmente popularidade partilhada" (WISEMAN; BAKER, 2005, p. 5) não somente entre as organizações internacionais que lidam com a educação, como também entre os vários atores locais que as adoptam como pressupostos dos seus programas sobre educação. Por regra, como Halpin e Troyna (1995) afirmam, o processo de "policy borrowing" tende essencialmente a legitimação de políticas, dado que existe a tendência de este processo ser intermediado pela ideologia política dominante, quer nos sistemas de educação do país de adoção, ou nos dos países nos quais elas são geralmente originárias.

Essa institucionalização das políticas internacionais é sustentada por vários mecanismos, todavia destacamos aqueles descritos ainda por Wiseman e Baker (2005), como a legitimada "sabedoria educacional corporificada por duas organizações econômicas multinacionais dominantes, em particular, o Banco Mundial e a OCDE, tendo ambas a autoridade internacional em disseminar ideias sobre educação e algumas políticas sobre educação, bem como fazer cumprir a implementação de ideias em certos países no mundo" (p.5). Na realidade destas organizações, Nordtveit (2012) particulariza o Banco Mundial, cujos documentos são usados para criar um ideal da educação mundial 
e que são traduzidos em "estratégias de implementação; e em filosofias da educação, fins e valores" (p. 22).

Napier (2005) também realça o valor das ideias nos processos de internacionalização das políticas de educação. Para ele, os elementos substanciais das reformas educativas continuam significantemente informados pelo pensamento comparativo e pela adoção de ideias importadas. Devido a esses padrões da educação global, da convergência e do empréstimo por atacado dos "ingredientes" da reforma,

[...] uma nova família de objetivos da reforma aparecem nas agendas das reformas dos países no mundo inteiro, independentemente do seu nível de desenvolvimento. [...] Elas [as contribuições desta família de objetivos] incluem as considerações sobre o conteúdo; métodos; desenvolvimento e uso de tecnologias; questões relativas aos professores; números e estatísticas em formatos diversos; relações entre os professores e as administrações; questões sobre gestão e orçamentos; relações professores-comunidade; as necessidades da sociedade e do país em relação à educação; o papel do governo na educação em termos de centralização; e os processos de descentralização. (NAPIER, 2005, p. 64).

Karen Mundy (2005) dá a conhecer que pesquisas recentes têm revelado o crescente impacto da internacionalização. Nessas pesquisas constata-se a natureza PluriScalar dos processos das políticas de educação contemporâneas que "de modo crescente envolvem múltiplos níveis de governo (do local ao internacional), novos tipos de atores (incluindo redes profissionais, organizações não governamentais e atores do sector privado com alcance transnacional)”. (MUNDY, 2005, p. 717). Essa realidade reconfigura a ação e o tipo de atores que exercem influência sobre o processo de concepção da política da educação.

Como atores, os governos vão tendo as suas atividades diluídas pela ação e pela agenda das organizações intergovernamentais e também as multilaterais. Sobre a ação do governo, Hill (2005) diz que existem várias maneiras que permitem a um governo determinar ou influenciar a educação - como provedor direto, como financiador de serviços providos por outros atores e como regulador de serviços prestados por privados. Quando o governo age na condição de provedor de educação, tendem a ser salvaguardadas as vantagens sociais conducentes (apesar de nem sempre acontecer) às ações redistributivas e ao fomento da mobilidade social. Nessa qualidade, e à medida que 
a educação se transforma em prioridade política, o governo tende a tornar-se cada vez mais interventivo, adotando as estratégias de reformas no sentido top-down e de implementação imediata (LEVIN, 2001).

Para além do governo, outros atores se sobressaem no contexto da internacionalização da educação. Em razão do âmbito e da realidade deste estudo, focamos a ação do Banco Mundial, apesar de citado como um dos principais agentes de influência sobre as políticas públicas em países em desenvolvimento, e também nas agências das Nações Unidas, como a Unesco e o Unicef.

O Banco Mundial, nas ultimas décadas, "reinventou-se no sector da educação e apresenta-se como produtor de conhecimento e gestor de conhecimento" (STEINERKHANSI, 2012, p. 4). É sob essa condição, ainda segundo a autora, que determina sobre o que funciona e o que não funciona na realidade das políticas de desenvolvimento da educação. Para além desta condição, o Banco Mundial transformou-se na maior fonte singular de capital para o desenvolvimento na área da educação internacional, devido a cerca de três bilhões de dólares anuais aplicados em empréstimos (HEYNEMAN, 2005). $\mathrm{Na}$ África subsaariana, esses empréstimos são essencialmente aplicados na reconstrução de escolas primárias nas realidades do pós-conflito.

Klees (2012), ao referir-se à ideologia do Banco Mundial na educação, diz que, para esse Banco, a educação não é um direito. Apesar de seu documento, que reporta a estratégia de educação até 2020, referir que a educação é um direito humano básico, Klees constata que a menção do direito se limita a esse enunciado porque o mesmo já não é reforçado no documento e se sobressai o facto de que "o direito à educação não é usado de modo algum como a base da estratégia do Banco Mundial” (KLEES, 2012, p. 50). O não reconhecimento ou a falta de reconhecimento da condição de direito como qualidade fundamental da educação, qualquer perspectiva de programas de educação a adotar passa à margem da necessidade de se garantir o acesso universal, e também uma educação de qualidade como requisito da educação a prover. Aqui reside a diferença entre a ideologia do Banco Mundial e a dos outros atores. Porque, justifica Klees, enquanto que esse Banco relutantemente adicionou uma frase ou duas nos seus relatórios sobre a condição de 
direito da educação, as outras agências internacionais transformaram todos os seus programas de modo que essa condição fosse o elemento predominante dos mesmos.

Essa não ênfase no direito nos programas da educação (para todos) do Banco Mundial é corroborada por Mundy e Ghali (2009), ao salientarem que o Banco Mundial no seu programa de ajustamento estrutural defendeu cortes no financiamento à educação pelos governos. Ao se transformar no ator multilateral mais influente nas políticas de educação na década de 1990, o quadro de ação emergente do Banco para o financiamento da melhoria da educação divergiu significativamente das anteriores atividades da “educação para todos”. Virtualmente, em todos os seus empréstimos no sector,

[...] o Banco Mundial introduziu um menu padronizado de políticas de reforma, incluindo a descentralização, a reestruturação dos serviços públicos (particularmente o tempo do contrato dos professores), programas padronizados de avaliação educacional, a inclusão de provedores privados de serviços (MUNDY e GHALI, 2009, p. 722).

O direito à educação é manifesto pelo Unicef como seu objetivo maior, e pela Unesco como a sua missão constitucional. Koichiro Matsuura ${ }^{73}$ (2002), nas suas alocuções na obra "A UNESCO e os desafios do novo século", reitera que a ideia da educação para todos se constitui na essência do mandato conferido a esta organização no âmbito do sistema das Nações Unidas. Quanto ao direito à educação, Matsuura apela para que não se olvide que o mesmo constitui um direito inalienável de todo indivíduo. Por isso, no Fórum Mundial de Educação (DAKAR, 2000), justifica que a Unesco assume o compromisso da educação porque é um direito fundamental integrado na Declaração Universal dos Direitos Humanos, e também porque a educação "ajuda a melhorar a segurança, a saúde, a prosperidade e o equilíbrio ecológico no mundo, da mesma maneira como incentiva o progresso social, econômico e cultural, a tolerância e a cooperação internacional". Sobre o seu fim, a educação extravasou a condição de direito fundamental consagrado em documentos universais e adotados localmente, passando também para uma precondição para se idealizar e materializar qualquer tipo de desenvolvimento, quer seja para a "redução da taxa de desemprego e de pobreza, para o progresso social e

\footnotetext{
${ }^{73}$ Koichiro Matsuura foi Director-Geral da Unesco entre 1999 e 2009.
} 
cultural, para a promoção de valores democráticos e para o estabelecimento de uma paz duradoura".

Os governos, via seus sistemas de educação, são convocados a desenvolver perspectivas para obterem uma educação que seja autêntica, acessível para todos, sem exclusão ou discriminação de qualquer natureza. Os desafios neste pressuposto da educação são, entre outros enunciados por Matsuura (2000), os de;

1. Criar uma educação cujo conteúdo e métodos estejam ajustados às suas realidades sociais e culturais. Sua herança linguística e seu potencial endógeno, no que diz respeito a habilidades e práticas, bem como os valores que escoram a sua sociedade, têm de figurar como elementos centrais dessa educação, para que ela conquiste a aprovação convicta das populações às quais se destina. Além disso, esta educação tem de ser moderna, motivo pelo qual é essencial reforçar o ensino de ciência desde o nível primário, o que constitui uma precondição para a autonomia de cada indivíduo numa sociedade globalizada.

2. Desenvolver serviços de educação básica acessíveis a todos, inclusive aos mais pobres, adultos analfabetos, crianças fora do sistema escolar - quer estejam no trabalho, nas ruas ou como refugiados - , mediante uma estratégia que envolva tanto o sistema de educação formal como as alternativas oferecidas pelo setor informal. A educação básica tem de tornar-se um campo que seja livre de todas as formas de exclusão e de discriminação.

Outra das questões que a origem incorpora na política da educação são as visões/filosofias sobre educação que se desenvolvem com as políticas de educação. Fullan (2007) elucida que, em regra, se assume que as mudanças são induzidas na educação porque são desejáveis dentro de um conjunto de valores sobre a educação que, se acredita, são melhores do que as em curso. Considerando-as como dominantes no universo da internacionalização da política, Vally e Spreen (2001) apresentam a teoria do capital humano e a fundada no direito (à educação). Explicam os autores que, sob a teoria do capital humano, a educação é essencialmente reduzida ao seu valor da realização econômica para o indivíduo e para a economia como um todo. O saber é então "uma 
mercadoria que os indivíduos devem trocar por uma qualificação ou credenciais que podem ter algum valor no mercado competitivo" (p. 178). E a educação e a formação são "transformadas em panaceia para a performance econômica, uma vez que se assume que o investimento no capital humano e na tecnologia vai automaticamente aumentar a produtividade e as habilidades". (VALLY; SPREEN, 2001).

Na perspectiva da teoria fundada no direito (à educação), o

[...] governo tem a obrigação de respeitar, proteger, promover, e cumprir com a materialização destes direitos pela política e pela legislação; apesar da imperfeição destas obrigações e de os conteúdos específicos e o significado do direito à educação continuarem abertos ao debate. (VALLY; SPREEN, 2012, p. 182).

A política de educação global que reflete esta visão, nos dias de hoje, é a "Educação Para Todos" (EPT) sob égide da Unesco e subscrita por vários países, entre os quais Angola.

O princípio do acesso universal à educação básica defendido pela EPT é uma questão que se sobrepõe às agendas e aos contextos dos Estados subscritores. É nesta natureza que o acesso como valor do direito à educação se assume como "uma questão global de facto e como tal, parte da cultura global, da estrutura de governo e do mercado. [Esta e as demais questões do direito] tornaram a EPT em mais uma questão de direitos humanos mais do que simplesmente uma estratégia nacional para o sucesso econômico" (BAKER e WISEMAN, 2007, p. xiv), o que alarga a perspectiva do direito universal à educação como uma visão emergente uma ordem mundial que é subscrita pela comunidade internacional, governos e sociedade civil (MUNDY, 2007).

Todavia, questionamentos, ou melhor, desafios são lançados como instrumentos de reflexão em torno do projeto e do ideal da "educação para todos". Em países africanos, em particular, algumas vozes chamam a atenção sobre o não respeito da peculiaridade dos desafios da educação na realidade do continente. Depois das experiências com a colonização, os programas de cooperação com governos ocidentais e agências internacionais (como o Banco Mundial), a expectativa atual é de que os princípios, valores e estratégias que sustentam as políticas da educação para o continente devem contribuir para que a educação desenvolva o seu fim social e salvaguarde as conquistas 
das civilizações africanas. Nes (2003), por exemplo, no seu texto "Porque é que a educação para todos deve ser inclusiva?", questiona quem eram os "todos" presentes em Jomtien. Prosseguindo, "a conferência foi intitulada de "conferência mundial", mas o seu alvo para as iniciativas propostas foram claramente não todos os países, mas os países do "terceiro mundo", com o objetivo de usarem as pesquisas e conselhos do ocidente para a implementação de mudanças no sul” (NES, 2003, p. 67).

Quanto ao conteúdo da educação, o autor afirma que foi uma questão negligenciada porque não se prestou a devida atenção às preocupações dos contribuintes africanos à conferência sobre a necessidade de se adotar a educação como veículo para preservar as normas da cultura, os valores, as práticas tradicionais e as identidades históricas dos povos africanos. Nes (2003) resume essa preocupação na visão de que "o contexto cultural, bem como o natural e o social da criança guiam o trabalho e não as disposições individuais da criança ou as tradicionais disciplinas de estudo" (p. 76).

Al-Mufti (1997) realça a pretensão dos países em desenvolvimento em cumprirem com os objetivos da "educação para todos" como propostos pela Unesco. Mas a necessidade de responder à crescente procura pela educação sobrepôs-se à necessidade de assentar o desenvolvimento da educação na qualidade da oferecida pelas escolas. Como resultado, os obstáculos atuais ao aperfeiçoamento da educação resumem-se na superlotação das salas, nos métodos de ensino inadequados, na débil formação dos

professores, na não ênfase da participação democrática na sala de aula, na promoção da aprendizagem cooperativa e no apelo à imaginação para a resolução dos problemas (AlMUFTI, 1997).

\subsection{A adopção das políticas educacionais}

A adopção, como definida por Levin (2001), é o que acontece às reformas entre a sua proposta inicial e a sua atual passagem à lei ou à regulação, uma vez que as políticas, como são finalmente adoptadas ou convertidas em legislação, diferem das propostas originais. 
Levin (2001) adianta que as políticas como ideias são necessariamente transformadas em um conjunto de procedimentos. É no curso desse processo de transformação que surgem alterações às ideias inicialmente propostas. Nesse estágio, os servidores públicos tendem a usar as propostas políticas para atingir determinados fins. Os funcionários públicos, tendo as suas próprias ideias sobre o que é desejável na política, empenham-se em promovê-las nas esferas da sua influência. Para o grupo dos políticos reservam a sua atenção para aqueles aspectos que elegem como vitais - por norma, muito poucos - deixando assim aos burocratas a responsabilidade de uma quantidade considerável de ações dentro do espaço proporcionado de iniciativas.

O processo de consulta é também uns dos procedimentos que pode influenciar a natureza das ideias inicialmente propostas para uma determinada política. Casos há em que os governos procuram reunir consensos sobre as suas agendas políticas e as políticas públicas daí derivadas antes do processo de implementação. Quanto a esse processo, Levin (2001) diz que apesar de a existência da consulta aparentar uma determinação do governo em aprender com os interessados e afetados pela política, em alguns casos, "os processos de consulta são concebidos mais para impressionar as pessoas com a abertura do governo do que como uma ocasião genuína para o debate e diálogo que pode realmente conduzir a mudanças na questão proposta” (LEVIN, 2001, p. 122).

\subsection{A política educacional em Angola e sua origem}

O fundamento deste estudo é a educação e como ela se manifesta na política de educação em Angola, quer na forma de texto legal quer em outros programas vinculados

à efetivação da educação. Como já adotado nos pontos anteriores, é a legislação que vamos tomar como a entidade que congrega os desígnios da política, pelo menos ao nível da sua proposição. Stromquist (2007), sobre este princípio, afirma que "as leis, mesmo quando não implementadas, podem jogar um papel fundamental. As leis educacionais servem para reforçar o mandato social conferido às escolas” (p. 266).

Na Lei de Bases do Sistema de Educação (ANGOLA, 2001a) buscamos a filosofia que fundamenta a educação a desenvolver. A aprovação dessa lei é fundamentada pela vontade de realizar a escolarização de todas as crianças em idade 
escolar, de reduzir o analfabetismo e aumentar a eficácia escolar. Ela também se fundamenta na necessidade de readaptação do sistema educativo para responder as novas exigências da formação dos recursos humanos definidos como necessários para o progresso socioeconômico da sociedade angolana. Essa readaptação ocorre no momento de transição de um ideal de economia de orientação socialista para uma de mercado.

No ponto 2 do artigo $1^{\circ}$, a educação que se realiza no sistema de educação proposto visa a "formação harmoniosa e integral do indivíduo, com vista à construção de uma sociedade livre, democrática, de paz e progresso social" (ANGOLA, 2001a). Quanto aos objetivos gerais, os mesmos já apresentados no capítulo anterior, tendem a desenvolver habilidades, aptidões e conhecimentos que possam concorrer para o desenvolvimento sócio econômico. Nessa lei não encontramos a menção direta de uma visão da educação como um direito.

Como característico dos processos de políticas públicas, essa abordagem da educação presente, incorporada pela LBSE, resulta de etapas específicas. A essas etapas designamos por origens da política da educação de Angola. A demarcação desse processo é a etapa diagnóstica realizada em 1986. Nesta etapa, ao Ministério da Educação foi incumbida a missão de repensar a educação em Angola devido ao reconhecimento da ineficácia da educação na época de materializar o projeto ideológico pensado e também da realização da educação como ato pedagógico. Como resultado, esse diagnóstico chegou a conclusões que entre elas extraímos a seguinte: para cumprir essas indicações é imprescindível produzir mudanças substanciais no Sistema Nacional de Educação, as quais não podem reduzir-se a uma simples alteração de conteúdo, nem a modificações parciais, mas sim transcenderem para transformações estruturais fundamentais e novas concepções no enfoque da educação, para o desenvolvimento da nova geração (ANGOLA, 2013b, p. 67).

Numa outra conclusão, recomendava-se ao Ministério da Educação as medidas julgadas necessárias para que a abordagem sobre a educação conhecesse outra perspectiva. Recomenda-se que a

[...] execução dessas mudanças na prática deve estar, em primeiro lugar, assegurada por uma correta organização geral do sistema que garanta, tanto horizontal como verticalmente, a orientação e controlo de toda a atividade 
educacional, e assegurada, em segundo lugar, pela criação de condições materiais que permitam levá-la a cabo com efetividade: edifícios escolares, mobiliário e todo aquele material de ensino que contribua para a formação integral do indivíduo e, sobretudo, que implique um reconhecimento social para com a pessoa do professor (ANGOLA, 2013b, p.67).

Contudo, a implementação das recomendações desse relatório e as etapas subsequentes pensadas foram prejudicadas principalmente pela crise econômica da época. Em 1982 aconteceu uma queda acentuada do preço do petróleo no mercado, o que desencadeou uma vaga de crises econômicas em muitos países. Sendo a economia de Angola baseada essencialmente na exportação do petróleo, o país também foi afetado por essa crise na economia mundial. Nesse período, particularmente entre 1986 e 1991, como diz Ferreira (1999), tiveram lugar vários acontecimentos e mutações nos planos econômico e político, em nível interno e internacional. O país viveu uma persistente crise econômica e social, o que acelerou a percepção do esgotamento da economia. Essa percepção sustenta-se com o

[...] reconhecimento da existência de uma acentuada quebra da produção interna, da desorganização dos circuitos de comercialização no interior do país, da diminuição das receitas cambiais, da dificuldade de assegurar as importações ao nível desejado e planificado e do agravamento da dívida externa (FERREIRA, 1999, p.115).

Além desse aspecto, aconteceram alterações na ordem mundial com o fim da URSS, a queda do muro de Berlim e o fim de regimes comunistas em países do leste europeu, como a Hungria e a Polónia. Em nível regional foram assinados os acordos de paz na Namíbia e a consequente independência da mesma. Há também a assinalar as conversações entre Angola, Cuba e África do Sul, sendo que um dos acordos foi a retirada das tropas cubanas de Angola. Esse contexto levou o Governo de Angola a pensar em mudanças políticas. É esse ambiente que, adianta Ferreira (1999), influenciou o trabalho do III Congresso do MPLA PT, em 1989, em que se criaram as condições para se dar início ao "desmantelamento do sistema econômico de direção central e planificada e ao regime de partido único" (p. 146), tendo por isso sido aprovados os documentos relativos à adoção de um sistema político pluripartidário conducente à edificação de um Estado democrático de direito, e a recomendação de uma revisão constitucional que adequasse os domínios da vida da sociedade e do Estado aos novos princípios. No plano 
econômico, com as propostas para o período 1991-1995, decidiu-se pela "liquidação do sistema econômico de caráter administrativo, devendo aparecer em sua substituição o mercado cujo desenvolvimento e funcionamento deve ser provido pela política econômica" (FERREIRA, 1999, p.147).

Como resultado dessas mudanças, entrou em ação o Banco Mundial como o ator que iria influenciar o curso da elaboração da política de educação no país. Angola tornouse membro do grupo do Banco Mundial em 1989, e a assistência desse Banco ao país começou em 1991. No setor da Educação, o primeiro projeto foi designado por “Education Project 1", com a avaliação inicial de US \$27,1 milhões de dólares, como valor do empréstimo.

Para o Banco Mundial, como mostra o relatório da implementação e conclusão,

[...] o projeto estava devidamente incorporado na estratégia global de Angola para a reconstrução e os objetivos do projeto foram totalmente consistentes com a estratégia do governo em desenvolver uma perspectiva do sector para o ajuste, a reabilitação, revitalização, e a progressiva expansão do sistema de educação. O projeto foi produto de um diálogo extensivo entre o Governo e o Banco. (WORLD BANK, 1992).

Essa certeza do Banco foi confirmada por carta, do então ministro da educação, datada de 4 de maio de 1992 e dirigida ao então diretor do departamento Sul-Central, Índia e Oceania. Nessa carta, informa-se sobre a política para o setor da educação cujos objetivos são a reforma estrutural e a redefinição dos objetivos da educação. Promete-se também que a reforma educativa será acompanhada por medidas para a promoção da qualidade, concebidas particularmente para conceber programas de estudos e avaliações, nos vários níveis de educação, que se tornem relevantes para a nova situação e as necessidades da época. Também durante a fase de negociações do crédito para o projeto, o Governo de Angola proveu ao Banco o esboço da declaração política da reforma e reafirmou o seu "compromisso em ajustar a educação nas linhas acordadas com o IDA durante a missão de avaliação, incluindo a aplicação da nova estrutura em todas novas escolas, independentemente dos seus recursos financeiros; e limitar os turnos escolares em dois" (WORLD BANK, 1992). 
Sobre o projeto em si, o mesmo teve como objetivos: (1) corrigir as principais ineficiências no setor da educação; (2) preparar uma estratégia para uma ampla reabilitação, revitalização e a progressiva expansão do sistema de educação. Buscou-se a melhoria dos inputs da educação e a adaptação da estrutura do sistema da educação ao modelo baseado nos inputs para elevar a qualidade. A adaptação da estrutura consistia, segundo o projeto, em:

1. Capacitar o Inide para o provimento de manuais para os professores e a reabilitação de prédios de escolas primárias.

2. Reforçar a capacidade do MED, pela formação de técnicos e gestores em nível central e provincial nas áreas do planeamento, orçamento, e gestão de recursos humanos.

3. Elaborar estudos para preparar o futuro investimento para definir o quadro de ação financeiro e o ritmo da reforma, a reabilitação e a expansão do sistema da educação.

$\mathrm{Na}$ ótica do Banco, os objetivos estavam consistentes com a estratégia de assistência para o país, que consistia em assistir e "promover o crescimento econômico, melhorar a pobre condição social de muitos angolanos e assegurar que o ambiente do país esteja protegido. O projeto teve também uma perspectiva do gênero nos objetivos para garantir o acesso sem restrições de gênero à educação” (WORLD BANK, 2000).

Esses objetivos e também a adaptação proposta à estrutura do sistema de educação eram a resposta para as questões levantadas, pelo Governo de Angola, desde o diagnóstico de 1986, e pelo Banco Mundial, nas suas missões de avaliação técnica para a concepção do projeto. Essas questões resumem-se:

a. $\mathrm{Na}$ inadequação da atual estrutura, principalmente na sua habilidade, em alcançar a alfabetização permanente durante os 4 anos de educação básica.

b. Na baixa qualidade das condições de ensino e de aprendizagem existentes.

c. Na fraca capacidade de gestão do setor. 
d. No pobre desenvolvimento da pós-educação básica, para o desenvolvimento de recursos humanos num país profundamente debilitado nesse aspecto.

e. No baixo nível de financiamento.

Para além dos objetivos da reforma acima retratados, outras questões produzidas e que se ajustaram à filosofia do Banco foram: a reforma da estrutura do sistema (ver Anexos II, III e IIV) e também a entrada de operadores privados no provimento da educação. Na estrutura resultante da reforma educativa sobressaíram as transformações no ensino primário. O ensino primário regular das anteriores 4 classes passa para 6 classes. Acreditamos que essa alteração seja para satisfazer a visão expressa sobre a incapacidade de os estudantes não atingirem os níveis de educação almejados depois da 4. ${ }^{a}$ classe porque atribuiu-se aos baixos índices demonstrados pelas diferentes avaliações efetuadas durante as várias etapas diagnósticas, quer pelo Governo quer pelos seus parceiros, a uma questão da estrutura, isto é, a pouca duração de preparação dos estudantes entre o ensino primário e o secundário. Com o alargamento para 6 classes, acontece também o alargamento da mono-docência; assim, até a 6 . $^{\mathrm{a}}$ classe os estudantes são acompanhados por um único professor que, se espera, comece a trabalhar com o grupo da 1 . $^{\text {a }}$ classe até a conclusão dessa etapa dos estudos.

O ensino secundário ganhou dois ciclos. No primeiro ciclo foi- reduzida uma classe, passando a ser constituído por 3 classes, nomeadamente a 7., 8. ${ }^{a}$ e 9. ${ }^{a}$. O segundo ciclo do ensino secundário passou a ter a seguinte estrutura, em função da natureza da formação provida: a formação média normal e a formação média técnica são constituídas pelas $10 .^{\mathrm{a}}, 11 .^{\mathrm{a}}, 12$. $^{\mathrm{a}}$ e $13 .^{\mathrm{a}}$ classes.

Sobre a entrada de outros operadores, neste caso, provedores de ensino, salientase a entrada do ensino privado como modalidade de ensino oficial na República de Angola. Apesar das responsabilidades constitucionalmente consagradas, o Estado deixou de ser o único provedor da educação. Operadores privados são convocados para, em parceria com o Estado, buscarem a satisfação da demanda por educação. Usualmente o fundamento para a educação privada é relacionado com a busca de escolas de qualidade devido à incapacidade do Estado em prover educação que respondesse às expectativas 
dos cidadãos. Essa perspectiva foi, e ainda é, válida para a realidade angolana. Mas, na maior parte das situações, principalmente nos principais centros urbanos e algumas regiões do interior do país, o recurso ao ensino privado era a única possibilidade para se ter acesso à educação. $\mathrm{O}$ acesso à escola sobrepunha-se à qualidade devido à ausência de uma escola pública ou, quando elas existiam, não estavam à altura de satisfazer a demanda.

Outra área da educação que também conheceu a entrada de operadores privados é a produção dos manuais escolares. Segundo a missão de avaliação do Banco de Mundial de 1992, os manuais são o segundo fator que mais afeta a qualidade da educação. Constata-se a escassez de manuais no primeiro nível (ensino primário), sendo a proporção de 5 alunos por livro. Ao Ministério da Educação, via Inide, cabia a responsabilidade da edição dos manuais. Contudo, o Inide, apesar de responsável pela concepção e a publicação dos manuais, não tinha na sua equipa editores com a formação requerida, designers e gestores de produção do livro. A maior parte dos livros disponíveis data do período imediato à independência.

Acrescenta-se nesse processo outro ator, a Unesco. De 5 a 9 de março de 1990 aconteceu a Conferência de Jomtien, cujo desfecho foi a Declaração Mundial sobre a "Educação para Todos". Essa declaração incidiu, principalmente, sobre a satisfação das necessidades básicas de aprendizagem. A inquietação que orientou a conferência foi a observação de que, 40 anos após a Declaração Universal dos Direitos Humanos afirmar que "toda pessoa tem direito à educação", estimava-se que mais de 100 milhões de crianças, das quais pelo menos 60 milhões de meninas, não tinham acesso ao ensino primário. Mais de 100 milhões de crianças não conseguiam concluir o ensino de base e outros milhões que o concluíam não adquiriam as competências e as habilidades esperadas. Entre os adultos, mais de 960 milhões (dois terços dos quais mulheres) eram analfabetos. Acrescentam-se os elevados índices do analfabetismo funcional em países industriais ou em desenvolvimento. Angola, como país, situa-se dentro das inquietações levantadas na conferência e esteve presente com uma delegação chefiada pelo então Ministro da Educação. 
Em Dakar, 24 a 26 de abril de 2000, sob os auspícios das Nações Unida, via suas agências afins, aconteceu o Fórum Mundial da Educação. Conclui-se nesse fórum que as metas definidas em Jomtien estavam longe de ser alcançadas, particularmente pelos países da África Subsaariana. O Fórum, para além de renovar os desafios e compromissos da declaração de Jomtien, adotou o Quadro de Ação de Dakar até 2015 e foram estabelecidos os seguintes desafios:

- Cuidados da primeira infância;

- Universalização do ensino primário;

- Preparação para a vida ativa;

- Redução dos índices de analfabetismo (pelo menos pela metade);

- Garantia da equidade do gênero;

- Promoção da qualidade da educação.

Ao contrário de Jomtien, em Dakar conceberam-se também mecanismos de acompanhamento, coordenação e monitorização da implementação das atividades previstas no quadro de ação. Recomendou-se aos países adotarem planos nacionais de “Educação para Todos” (EPT).

Esses eventos mundiais, subscritos por Angola, ocorreram entre dois marcos da política da educação em Angola. Entre o período 1991-2001, trabalhou-se na concepção do novo sistema de educação e também se aprova a Lei n. ${ }^{\circ}$ 13/01 de 31 de dezembro LBSE. No período 2002-2012 homologou-se o texto oficial da reforma educativa e formalizou-se a implementação do novo sistema da educação pelo Decreto n. ${ }^{\circ}$ 2/05 de 14 de janeiro (ANGOLA, 2005). Apesar de a LBSE não fazer menção explícita dos compromissos e das metas de Dakar, nem a sua adoção nos objetivos definidos, a política de educação adotada incorporou os pressupostos de Jomtien e de Dakar. Para as autoridades, essa é a demonstração da consciência do Estado, das suas responsabilidades em cumprir as deliberações do fórum mundial da educação e a busca da qualidade da educação nacional (ANGOLA, 2001b). 
Por exemplo, na "Estratégia Integrada para a Melhoria do Sistema de Educação 2001-2015”, de agosto de 2001, declara-se que

[...] para além da presente estratégia responder a orientações pertinentes do Governo, a mesma enquadra-se igualmente no contexto da implementação de recomendações de conferências regionais e internacionais no domínio da educação e que engajam o nosso país, nomeadamente o Decénio Africano de Educação, instituído pela OUA, o Quadro de Ação do Fórum Mundial sobre Educação Para Todos e o Decénio das Nações Unidos de Alfabetização Para Todos cujos compromissos estendem até 2015 (ANGOLA, 2001b, p.10).

Como resultado dessa perspectiva de abordagem do Governo sobre os processos de elaboração de políticas públicas, em particular as fontes de ideias que informam sobre os conteúdos propostos e adotados para mesma, em 1995, o Ministério da Educação e Cultura e algumas agências das Nações Unidas definiram o Plano Quadro Nacional de Reconstrução do Sistema Educativo para o decênio 1995-2005, visando o objeto de conformar o projeto de educação às "exigências para o desenvolvimento humano sustentável numa perspectiva de reconstrução" (ANGOLA, 2001b, p.11) num sistema que se ajustasse aos desafios concebidos.

Também, o "Plano Nacional de Ação da Educação para Todos (2001-2015)" é apresentado pelo Governo de Angola como a resposta à diretiva da Unesco para se criar uma comissão nacional da educação para todos com a responsabilidade de conduzir o processo de elaboração alargado e um plano de ação nacional e também organizar a consulta pública (como fórum nacional) da educação para todos. Esse processo da concepção e elaboração do Plano Nacional de Ação da Educação Para Todos observa "rigorosamente os princípios e a metodologia estabelecida pela Unesco, com as devidas adaptações à realidade e perspectivas da República de Angola” (ANGOLA, 2001b, p.72).

A consulta pública nacional sobre o anteprojeto da ação nacional da EPT realizouse numa parceria entre o Ministério da Educação e a Unesco, em abril de 2004. Os objetivos desse encontro foram: buscar consenso nacional sobre os desafios da educação em Angola, considerados o Quadro de Ação de Dakar e os Objetivos e Metas do Desenvolvimento do Milénio; mobilizar o envolvimento de instituições públicas, privadas de solidariedade social, confissões religiosas, sindicais, sócio-profissionais, entre outras, na implementação do desafio da EPT em Angola; bem como refletir sobre a 
implementação dos objetivos e das estratégias do Quadro de Ação de Dakar nas condições concretas de Angola.

Participaram da consulta pública cerca de 350 delegados, entre membros do governo, deputados, consultores da Unesco, representantes da sociedade civil, entidades religiosas e ONGs nacionais e estrangeiras que, depois de terem feito um inventário das principais questões que comprometiam a efetivação da educação e de reconhecer os desafios da reconstrução do país no pós-conflito (a redução da pobreza e a estabilização macroeconômica), decidiram apelar à comunidade internacional e às instituições financeiras internacionais para que se juntassem à Unesco, ao PNUD, ao Unicef, ao FNUAP e ao Banco Mundial no apoio para a materialização do PAN/EPT. Não eram apenas as ideias que norteavam os princípios da educação projetada na política que tinham as suas origens nestas organizações multilaterais, mas também o governo, devido às suas limitações financeiras, técnicas e de profissionais, conferia a essas organizações o "controle" das estratégias de implementação da reforma a efetuar. Até que ponto essa perspectiva seria favorável à necessidade de se ajustar às demandas dos objetivos dos programas à realidade concreta de Angola?

Percebemos nesse processo da política educacional uma marcante presença das ideias da agenda global, que busca desenvolver um ideal comum da educação assentado nas ideias da organização da educação para uma cultura mundial assentadas em princípios partilhados por estados agrupados em organismos internacionais. Nessa realidade, o Estado e as agências em representação dos organismos internacionais reservam-se ao direito de decidirem as opções a submeter aos demais atores locais que poderiam disputar por ideias na agenda da educação. A razão reside, na parte do Estado pela sua cultura centralizadora na definição das opções de políticas, e pelos organismos internacionais, devido aos seus recursos financeiros necessários para programas sociais no país, e por simbolizarem o núcleo de experts sobre políticas de desenvolvimento relacionadas à educação. Essa redução da discussão da agenda a informações sobre das agendas mundiais limita-se o nível de reformulação da política às possibilidades de se incorporarem as demandas da realidade concreta do país, principalmente se considerarmos o histórico do desenvolvimento do sistema de educação. 


\section{CONSIDERAÇÕES FINAIS}

O direito à educação é o esteio das políticas de educação no contexto da mundialização da educação. Nesses projetos, a ênfase é centrada no homem, na sua condição natural, com o fundamento do provimento da educação para a salvaguarda da sua integridade na sua condição humana e histórica. Por isso, é um processo natural o surgimento de um sistema de educação em Angola. Contudo, as ideias que justificaram o surgimento desses sistemas nem sempre tiveram como esteio o direito à educação. É esse o fator que dá lugar ao desenvolvimento de obstáculos à efetivação do direito à educação.

Pensado para servir o projeto da colônia, o sistema de educação colonial assentado em leis de discriminação raciais, por meio do projeto de "civilização" e de instrução de mão de obra para a máquina de exploração colonial, fomentou o surgimento dos primeiros obstáculos, que é a não garantia do acesso à educação de muitos nativos e o respeito à história e à cultura dos pouquíssimos que tinham acessão à essa educação. Com essa negação e à medida que a sociedade angolana se "modernizava" ao estilo das sociedades ocidentais e da cultura global daí resultante, o sistema fomenta a negação da condição de indivíduos socialmente úteis para essas sociedades, bem como a garantia do crescimento social e econômico da maioria da população. São esses obstáculos que informam a visão da educação da Primeira República. Nesse período, ao se propor a adoptar um sistema socialista de Estado, a educação, pelo menos na perspectiva do acesso, representou uma conquista por permitir a possibilidade do acesso em massa à educação pública. Apesar dos condicionalismos nas liberdades e em alguns direitos impostos pela tipologia de Estado, a assumpção da educação como política social sob égide e responsabilidade total desse Estado, introduziu no sistema de educação valores e princípios condizentes com os defendidos pelo direito à educação. A educação de massas oferecida é declarada gratuita, obrigatória (até a 4. ${ }^{a}$ classe) e democrática, o que significava acesso à educação de todo cidadão, independentemente de sua cor, raça, credo religioso, gênero, origem social etc.

Mas os fundamentos dessa educação não se dignaram a desenvolver a condição de sujeito dos estudantes a ela submetidos em razão de o projeto educacional optar em responder às necessidades de formação ideológica dos cidadãos para o projeto de Estado 
socialista. Essa opção entra em conflito com a necessidade de uma educação cujo o fundamento é prover a cultura, em seu sentido amplo, ao cidadão, tendo em conta a sua condição humana e histórica. Nesse contexto, a não discriminação no acesso, como conquista, não é compensada com a qualidade da educação. $\mathrm{O}$ sub-financiamento, a qualidade dos professores e as condições materiais em que se realiza a educação condicionam a efetivação do direito à educação. Acrescenta-se também o fato de o projeto ideológico se ter sobreposto ao respeito das particularidades da educação tradicional que marcava a realidade de muitas comunidades angolanas e que informavam as suas interações sociais. Ao não levar em consideração a possibilidade de coabitação entre o projeto ideológico e a realidade em que se realizou os fundamentos da educação nesse período, não reconheceram a condição natural dos cidadãos desta república.

Acresce-se o fato de a educação na sua faceta de agente para o provimento de instrumentos conducentes à realização da condição econômica do cidadão não ter cumprido a rigor a necessidade de dotar a grande maioria desses cidadãos com habilidades e competências para se realizarem no mercado do trabalho. É no conjunto dessas evidências que se projeta os ideais para a política de educação na Segunda República. Por ela acontecer num Estado democrático de direito, julgamos que o contexto é propício para que os fundamentos do direito à educação sustentem a política educacional. Com o alargamento dos direitos fundamentais dos cidadãos nas leis constitucionais e com a entrada em cena de atores como as agências supranacionais os valores e princípios educacionais adentraram a política da educação, apesar de as declarações formais não terem justificado o provimento da educação como uma necessidade de se efetivar o direito a ela.

No plano concreto, o atendimento das questões respeitantes à efetivação do direito à educação contou com a contribuição dos fatores que a seguir mencionamos:

- O fim da guerra, entendendo que esta demandava orçamentos elevados, destruía estruturas públicas entre as escolas e obrigava a adesão em massa dos jovens ao exército em detrimento de outras áreas como o exercício do magistério. Ela produzia, também, milhares de deslocados internos entre a população. 
- A ampliação do número de salas como resultado da construção de novas escolas e a reabilitação das destruídas pela guerra ou pela falta de manutenção.

- A ação das organizações internacionais que ao exigirem a reforma da educação contribuíram para, ao menos, responder os desafios relativos ao acesso à educação.

- Os esforços para a melhoria da progressão dos alunos dentro do sistema de educação, o que concorre à diminuição dos índices de reprovação e abandono escolar.

- O crescimento e a diversificação da população com necessidades especiais de aprendizagem.

Em oposição, outros fatores continuam a apresentar-se como desafios à efetivação do direito à educação, nomeadamente:

- A língua portuguesa como única língua de instrução, o que continua a condicionar o aprendizado de muitos alunos no sistema. Este desafio impõe como demanda o ensino das línguas locais e nas línguas locais e a promoção da educação bilíngue, dado que o estatuto oficial da língua portuguesa é considerado como língua oficial do país.

- A ainda existência de muitas escolas em condições precárias e a superlotação das turmas.

- A qualificação dos professores, quer na formação inicial como na contínua.

- A logística de materiais didáticos.

- Os índices da população ainda por atender e a prevenção do abandono escolar.

- A desigualdade dentro do sistema educacional entre as regiões do país, meninos e meninas, em função do rendimento financeiro dos cidadãos.

- Os índices de analfabetismo.

- Os índices de pobreza entre a população. 
Para além destas questões, julgamos que existem outras que poderiam merecer estudos por poderem, a longo prazo, constituírem-se em obstáculos severos ao direito à educação e à ação das escolas públicas como instituições do Estado encarregadas de o efetivar. Na legislação sobre o ensino privado há um forte incentivo à iniciativa privada na educação, e com a possibilidade de serem financiadas pelo Estado. Tendo em atenção a ainda instável situação das instituições públicas do país, marcadas por corrupção, impunidade, partidarização e pelos conflitos de interesse entre o exercício do cargo público e os projetos privados, recomenda-se o estudo da atuação do privado na educação e sua relação com a ampliação ou não da garantia do direito à educação pelo Estado.

O financiamento da educação no país poderia também merecer um estudo porque o financiamento não deve ser necessariamente calculado pelos custos com os programas de investimento público na construção de infraestruturas, mas também pelos custos relacionados ao atendimento ao aluno no sistema. Depois da guerra civil, há os índices de crescimento da economia do país, o que demanda a análise da relação entre o crescimento econômico e o desenvolvimento social com a garantia dos direitos fundamentais, como o acesso à educação.

Outra preocupação pode advir da manutenção do risco de se garantir o acesso sem as devidas condições para o atendimento dos alunos já inseridos no sistema de educação. É necessário compreender as condições objetivas e subjetivas disponíveis no sistema para que se propicie um ambiente de aprendizagem favorável. Podemos mencionar a questão da merenda, há muito identificada como necessidade, dado os elevados índices de pobreza entre a população. O transporte escolar, como mostrado pelos MICS pode ser acrescido a estas condições que podem condicionar o atendimento dos alunos, uma vez garantido o acesso no sistema.

Na questão do conteúdo, houve ao longo da história da educação em Angola um "branqueamento 74 " do currículo para acomodar interesses instituídos pelo Estado. Esta ação resultou em conflitos nas relações sociais e também nas opções de desenvolvimento social, econômico e cultural no país. Reivindica-se uma educação que situe o educando

\footnotetext{
${ }^{74}$ Referimo-nos a omissão intencional de momentos e atores da história política e social do país e dos seus povos.
} 
na sua cultura antes de o engajar nas relações globais. Um currículo que não confere ao educando valores, princípios e conhecimentos para este se situar no ideal do nacionalismo, como definido aqui por Anísio Teixeira, não observa uma das condições dos direitos humanos, que é a salvaguarda e a promoção da cultura dos povos e do referido patrimônio material e imaterial.

Ao não se constatar a primazia do direito à educação da LBSE, qual seria a origem das ideias sobre a efetivação do direito à educação que adentram a política da educação? Cremos que o fundamento pode ser a ação das agências multilaterais.

Roger Dale (2001) ao examinar a relação entre globalização e educação, caracteriza duas abordagens sobre essa relação, nomeadamente a "Cultura Educacional Mundial Comum" (CEMC $)^{75}$, que se relaciona à pratica internacional constituída por estados-nação, e a "Agenda Estruturada para a Educação" (AGEE) ${ }^{76}$, sustentada por forças econômicas operando supra e transnacionalmente.

Não é nossa pretensão avaliar o mérito da análise de uma ou de outra abordagem sobre a globalização e a educação. Retomamos as abordagens para compreendermos a natureza da "cultura universal da educação" e apreender a partir dessas abordagens a relação do comportamento adoptado pelos principais atores da política pública em educação em Angola e os desafios que as mesmas erigem na ideia de uma agenda local para a educação, atendendo às particularidades dos desafios da sociedade angolana.

Dale diz que os proponentes da perspectiva da "cultura educacional mundial comum" (CEMC) defendem que os sistemas educativos nacionais e as categorias culturais resultam de modelos universais de educação, de Estado e de sociedade, mais do que através de fatores nacionais. Os atores são os estados-nação individualmente autônomos na forma de uma comunidade internacional. Esta perspectiva, pelo menos, na definição dos agentes que a difundem, diferencia-se da "Agenda Estruturada para a Educação" (AGEE) que resulta da ação de "forças econômicas operando supra e transnacionalmente para romper, ou ultrapassar, as fronteiras nacionais, ao mesmo tempo que reconstroem as relações entre as nações" (DALE, 2001, p. 136).

\footnotetext{
${ }^{75}$ Segundo Dale esta abordagem é desenvolvida por John Meyer e colegas seus e alunos de Stanford.

${ }^{76}$ Esta abordagem, ainda segundo Dale, é desenvolvida por ele próprio, mas sustentado-a nos trabalhos recentes de política internacional, como os de Cox, 1996; Mittelman, 1996; Hettne, 1996.
} 
Nessas abordagens, continua Dale, na abordagem CEMC, a educação é restringida à questão do currículo, reduzindo assim os sistemas educativos àquilo que se julga que eles pretendem alcançar. Não leva em consideração, a "exequibilidade [...] mandato, e a sua governação, isto é, como é que ele é coordenado no sentido de alcançar os desejáveis e possíveis fins". (DALE, 2001, p. 150). Em oposição, a AGEE toma a educação como variável dependente no processo da globalização, visto que a mesma sujeita-se aos “princípios e processos da distribuição da educação formal, na definição, formulação, transmissão e avaliação do conhecimento escolar" (DALE, 2001, p. 150) . Por isso, a necessidade de "descobrir como é que aqueles processos são financiados, fornecidos e regulados e como é que este tipo de forma de governação se relaciona com concepções mais amplas de governação dentre de uma sociedade" (DALE, 2001, p. 150).

Por essa razão, Dale considera ser crucial levar em consideração que a educação não se limita à prática da sala de aula para que se possa compreender coisas implícitas na política educativa e na governação. O padrão de governação educacional permanece em grande parte sob o controlo do estado, contudo novas e cada vez mais visíveis formas de desresponsabilização estão a prefigurar-se. A educação permanece um assunto interessante, político a nível nacional, e é moldado por muito mais do que debates acerca do conteúdo desejável da educação. As agendas nacionais para a educação são formadas mais em nível do regime do que em nível estrutural.

Logo, ao se subalternizar a questão dos conteúdos da educação, reduz-se o espaço da abordagem das questões relativas ao direito à educação que se manifesta pelo conteúdo da educação oferecida. Esta subalternização do conteúdo pode condicionar os fundamentos da educação nas realidades de Estados que buscam lidar com os desafios impostos pela ação colonial que, para além da pilhagem colonial, corroeu a estrutura social e cultural dos povos locais e, também, no caso de Angola, ao se deixar no plano secundário a restruturação do patrimônio cultural e estruturas sociais em detrimento de uma ideologia para fundamentar a opção do estado. A educação fundada no direito, para o caso de Angola, para além da função de mercado, defendida com os projetos que dão ênfase na educação profissional, deve propor-se a consolidar o projeto de nação, fundado na valorização da condição humana dos seus cidadãos. 
Concluindo, as políticas públicas em educação do Estado ganham mérito com a natureza da resposta que elas proporcionam aos desafios de consumar a educação como direito fundamental. Mas esses direitos, ao serem adoptados como fundamentos gerais da agenda mundial da educação, tendem a ser conformados a ideias globais fomentadas e sob a responsabilidade de organismos supranacionais que dificilmente as desdobram para atender aos desafios de natureza local e evitar a homogeneização na concepção de políticas locais. Para que as autoridades angolanas desenvolvam uma política que atenda, por um lado, aos aspectos gerais da agenda mundial da educação, e, por outro, aborde os desafios locais historicamente construídos na efetivação do direito, precisa desenvolver ambientes mais alargados e democráticos para a definição da agenda da educação. A capacitação e o empoderamento da sociedade civil no âmbito dos princípios e da responsabilidade cidadã são uma das condições para se diluir a bipolarização nas definições das ideias que permeiam a educação, e não sujeitar a agenda educacional às alternâncias de agendas de governo. 


\section{REFERÊNCIAS}

ABDI, Ali. A. Afrincan philosophies of education: counter colonial criticism. In: ABDI, ALI A.; CLEGHORN, Ailie. (Eds.). Issues in African education: sociological perspectives. New York: Palgrave Macmillan, 2005.

ADEYINKA, Augustus A. Widening access to education in the era of globalization: future, policy, thrusts. In: ODUARAN, Akpovire; BHOLA, Harbanus S. (Eds.). Widening acess to education as social justice. Dordrecht: Springer, 2006. p. 441-464.

AFONSO, Almerindo Janela. Estado, globalização e políticas educacionais: elementos para uma agenda de investigação. Revista Brasileira de Educação, n. 22, p. 35-46, jan./fev./mar./abr. 2003.

ÁFRICA PORTUGUESA. Mensário Estatístico Económico e Literário. Rio de Janeiro, n. 3, mar./abr./maio, 1932.

ALAVARSE, Ocimar Munhoz. A organização do ensino fundamental em ciclos: algumas questões. Revista Brasileira de Educação. v. 14, n. 40, p. 35-50, jan./abr. 2009.

ALMEIDA, Eugénio da Costa. Angola: potência regional em emergência. Lisboa: Edições Colibri, 2011.

AL-MUFTI, Inám. Educação e excelência: investir no talento. In: DELORS, Jacques et alli: Educação um tesouro a descobrir. São Paulo: Unesco; Edições ASA; Cortez, 1997. Primeira edição Brasileira. Relatório para a Unesco da Comissão Internacional sobre Educação para o Século XXI. p. 212-217.

ALTHUSSER, LOUIS. Ideologia e aparelho ideológicos do Estado: notas para uma investigação. In: ZIZEK, Slajov (Org.). Um mapa da ideologia. Rio de Janeiro: Contraponto, 1996.

AMNESTY INTERNATIONAL. The right to education. 2012. Disponível em: <www.amnesty.nllspa>. Acesso em: 12 nov. 2013.

ANGOLA. Assembleia Nacional. Lei de bases do sistema de educação. Lei n.13/01, de 31 de dezembro de 2001. Diário da República. n. 65, I Série, de 2001 a.

ANGOLA. Conselho da Revolução. Lei n. 4, de 9 de dezembro de 1975. Diário da República, n. 25, I Série, de 1975.

ANGOLA. Conselhos de Ministros. Estratégia integrada para a melhoria do sistema de educação,

2001-2015.

$2001 b$.

Disponível

em: 
<http://planipolis.iiep.unesco.org/format_liste1_en.php?Chp2=Angola>. Acesso em: 24 mar. 2014.

ANGOLA. Constituição 2010. Luanda: Imprensa Nacional, 2010a.

ANGOLA. Decreto n. 21/91. Diário da República, I Série, n. 26, 22 jun. 1991.

ANGOLA. Decreto n. 43/02. Diário da República, I Série, n. 70, 3 set. 2002.

ANGOLA. Decreto n. 2/05. Diário da República, I Série, n. 6, 14 de jul. 2005.

ANGOLA. Decreto Presidencial n. 20/11. Diário da República, I Série, n. 11, 18 jan. 2011a.

ANGOLA. Decreto Presidencial n. 207/11. Diário da República, I Série, n. 146, 2 ago. $2011 b$.

ANGOLA. Inquérito integrado sobre o bem-estar da população, 2008-2009. Angola, 2011c.

ANGOLA. Instituto Nacional de Estatística. Boletim de estatísticas sociais (2005-2008). Luanda, 2010b.

ANGOLA. Instituto Nacional de Estatística. Angola em números 2012. Luanda, 2012.

ANGOLA. Instituto Nacional de Estatística; UNICEF. MICS - inquérito de indicadores múltiplos: avaliação a situação das crianças e das mulheres angolanas no inicio do milênio. INE/Unicef, 2003.

ANGOLA. Instituto Nacional de Estatística; UNICEF. MICS - inquérito de indicadores múltiplos. INE/Unicef, 1997.

ANGOLA. Lei n. 23/92. Diário da República, I Série, n. 38, 16 set. 1992.

ANGOLA. Lei n.2/2013.

ANGOLA. Ministério da Educação. A reformulação do sistema e educação e ensino na $R P A$. Luanda, 1981a.

ANGOLA. Ministério da Educação. Balanço da implementação da $2 .{ }^{a}$ reforma educativa em Angola. Luanda, 2013a.

ANGOLA. Ministério da Educação. Consulta Pública sobre o plano de acção nacional de educação para todos. Regimento. Luanda, 2004a.

ANGOLA. Ministério da Educação. Consulta Pública sobre o plano de acção nacional de educação para todos. Documento final. Luanda, 2004b. 
ANGOLA. Ministério da Educação. Consulta Pública sobre o plano de acção nacional de educação para todos. Anteprojecto. Luanda, 2004c. t. 1.

ANGOLA. Ministério da Educação. Curso de formação de professores: organização escolar. Luanda, $1981 b$.

ANGOLA. Ministério da Educação. Evolução da educação e ensino em Angola (20022008). Luanda, 2008.

ANGOLA. Ministério da Educação. Informação sobre a implementação do novo sistema de educação. Reforma educativa do ensino primário e secundário. Luanda: INIDE, 2009.

ANGOLA. Ministério da Educação. Medidas para o saneamento e estabilização do actual sistema de educação e ensino de bases gerais para um novo modelo. Luanda, 1986a.

ANGOLA. Ministério da Educação. Medidas para o saneamento e estabilização do actual sistema de educação e ensino de bases gerais para um novo modelo. Luanda, 1988.

ANGOLA. Ministério da Educação. Nouveaux profils des orienteurs (encadreurs) pedagogiques e des professeurs d'ecole normale. In: SEMINAIRE REGIONAL DE L'UNESCO, Dakar, du 17 au 21 dec. 1979.

ANGOLA. Ministério da Educação. Plan d'action nationale d'education pour tous 20012015: Angola. Luanda: 2003.2 Disponível em: <http://planipolis.iiep.unesco.org/format_liste1_en.php?Chp2=Angola〉. Acesso em: 24 mar. 2014.

ANGOLA. Ministério da Educação. Plano estratégico do desenvolvimento da educação especial em Angola 2007-2015. Luanda, 2001c. Disponível em: < http://planipolis.iiep.unesco.org/format_liste1_en.php?Chp2=Angola>. Acesso em: 24 mar. 2014.

ANGOLA. Ministério da Educação. Plano-Quadro nacional da reconstrução do sistema educativo (1995-2005). Luanda, 1995.

ANGOLA. Ministério da Educação. Política nacional para a educação especial. s.d.

ANGOLA. Ministério da Educação. Reformulação do sistema de Educação. Luanda, 1990.

ANGOLA. Ministério da Educação. Relatório de Balanço do trabalho realizado pelo grupo de prognóstico do Ministério da Educação da República Popular de Angola do mês de março ao mês de Junho de 1986. 2. ed. Luanda: Editora das Letras, 2013b.

ANGOLA. Ministério da Educação. Relatório do balanço realizado pelo grupo de prognóstico do Ministério da Educação da RPA. Luanda, 1986b. 
ANGOLA. Ministério das Finanças. Despesas Públicas e Gestores Orçamentais. Luanda: Edijuris, 2005.

ANGOLA. Movimento Popular de Libertação de Angola. Teses e resoluções do $1 .^{o}$ congresso. 1977.

ANGOLA. R. P. Comissão Nacional do Plano. Direcção Nacional de Estatística. Anuário Estatístico. 1974.

ANGOLA. R. P. Opções para a reconstrução do sistema educativo: estudo sectorial. Luanda: UNESCO-UNICEF-MED, 1993. t.1.

ANGOLA. Relatório sobre as metas de desenvolvimento do milênio. 2010c. Disponível em: Em <http://planipolis.iiep.unesco.org/format_liste1_en.php?Chp2=Angola>. Acesso em: 24 mar. 2014.

ANSALONE, George. Exploring unequal achievement in the schools: the social construction of failure. Lanham, MD: Lexington Book, 2009.

ASHCROFT, Bill et alli. Key concepts in post-colonial studies. London: Routledge, 1998.

AUGUSTO, António Filipe. Assessing the introduction of the angolan indigenous language in the educational system in Luanda: a language policy perspective. El Monte, CA: Publishing Company, 2013.

AZEVEDO, Janete M. Lins de. A educação como política pública: polêmicas do nosso tempo. 2. ed. Campinas: Autores Associados, 2001.

BAKER, David P. The invisible hand of world education culture. Thoughts for policy makers. In: SYKES, Gary et alli. (Eds.). Handbook of education policy research. New York: Routledge, 2009.

BAKER, David P.; WISEMAN, Alexander W. (Eds.). Education for all: global promisses, national changes: international perspectives on education and society. Oxford: Elsevier, 2007. v. 8.

BARRO, Stephen M. Como os países financiam suas escolas? Financiamento da educação na América Latina - PREAL; tradução de Paulo Martins Garchet, Rio de Janeiro: Fundação Getúlio Vargas, 1999.

BASTOS. Pulquéria Van-Dúnem. CEAST - Conferencia Episcopal de Angola e São Tomé. O sistema judicial Angolano: funcionamento, virtudes e constrangimentos. In Justiça Social. III Semana Social Nacional. Luanda: Centro Cultural Mosaiko, 2007.

BEITER, Klaus Dieter. The protection of the right to education by international law. Leiden: Martinus Nijhoff Publihers, 2006. 
BENDER, Gerard. Angola under the Portuguese: the myth and the reality. Los AnglesCalifornia: University of California Press, 1978.

BHOLA, A. S. Access to education: a global perspective. In: ODUARAN, Akpovire; BHOLA, Harbanus S. (Eds.). Widening acess to education as social justice. Dordrecht: Springer, 2006. p. 44-68.

BIRCH, Anthony H. The concept and theories of modern democracy. 3. ed. New York: Routledge, 2007.

BITTENCOURT, Marcelo. Angola: tradição, modernidade e cultura política. In: REIS, Daniel Arão et alli. (Orgs.). Tradições e modernidades. Rio de Janeiro: Editora FGV, 2010. p. 129-144.

BOAHEN, Albert Adu. O colonialismo na África: impacto e significação. In: BOAHEN, Albert Adu (Ed.). África sob dominação colonial: 1880-1935. 3. ed. São Paulo: Cortez, 2011. v.7. (Colecção História Geral da África).

BONAVIDES, Paulo. Do Estado liberal ao Estado social. 11. ed. São Paulo: Malheiros Editores, 2013.

BRITO NETO, Manuel. História da educação em Angola: do colonialismo ao Movimento Popular de Libertação de Angola (MPLA). 2005. Tese (Doutorado em Educação) - Faculdade de Educação, Universidade Estadual de Campinas, Campinas, 2005.

BROCK-UTNE, Birgit. Language-in-education policies and pratices in África with a special focus on Tanzânia and South Africa - insights from research in progress. In: ZAJDA, Joseph (Ed.). International handbook on globalization, education and policy research: global pedagogies and research. Dordrecht: Springer, 2005. p. 549-565.

BROCK-UTNE, Birgit. Whose education for all? the recolonization of the african mind. New York: Falmer Press, 2000.

CABRAL, Amílcar. Identity and dignity in the context of the national liberation struggle. In: CABRAL, Amílcar. Return to the source: selected speeches of Amílcar Cabral. 3. ed. New York: Monthly Review Press, 1973. p. 57-69.

CASTELO, Claudia. Passagens para África: o povoamento de Angola e Moçambique com naturais da metrópole (1920-1974). Porto: Edições Afrontamento, 2007.

CHUNG, Fay. Educação na África actual. In: KLEES, Steven J.; SAMOFF, Joel; STROMQUIST, Nelly P. (Eds.) The World Bank and education critiques and alternatives. Boston: Sense Publishers, 2012. p. 225-227.

CORREIA, Adérito; SOUSA, Bornito de. Angola: história constitucional. Coimbra: Almedina, 1996. 
COSTA, Isabel da. (org.) Orçamento e despesas de educação. Perspectivas em Cabo Verde, Angola, Moçambique. Paris. UNESCO, 2003.

CRUZ, Elizabeth Ceita Vera. $O$ estatuto do indigenato: Angola: a legalização da discriminação na colonização portuguesa. Luanda: Chá de Caxinde, 2006.

DALE, Roger. Globalização e educação: demonstrando a existência de uma "cultura educacional mundial comum" ou localizando uma "agenda globalmente estruturada para a educação”? Educação, Sociedade e Cultura, n.16, 2001.

DAVIDSON, Basil. Portuguese colonial values: an introduction. In: FERREIRA, Eduardo de Sousa. Portuguese colonialism in Africa: the end of an era: the effects of portuguese colonialismo on education, science, culture and information. Paris: The Unesco Press, 1974.

DELORS, Jacques Delors et alli. Educação um tesouro a descobrir. São Paulo: Unesco; Edições ASA; Cortez, 1997. p. 212-217. Relatório para a Unesco da Comissão Internacional sobre Educação para o século XXI.

DIAS, Hildizina Norberto. As desigualidades sociolinguísticas e o fracasso escolar: em direç̧ão a uma prática linguístico-escolar libertadora. Maputo: Texto Editores, 2006.

EAGLETON, Terry. Ideologia: uma introdução. São Paulo: Editora da Unesp, 1997.

ELIAS, Norbert. O processo civilizador: uma história dos costumes. 2. ed. Rio de Janeiro: Zahar,1990. v. 1.

FERREIRA, Eduardo de Sousa. Portuguese colonialism in África: the end of an era: the effects of Portuguese Colonialism on education, science, culture and information. Paris: The Unesco Press, 1974.

FERREIRA, Manuel Ennes. A indústria em tempo de guerra: Angola, 1975-91. Lisboa: Edições Cosmos, 1999.

FERREIRA, Maria J. da S. M. Educação e política em Angola. Uma proposta de diferenciação social. Cadernos de Estudos Africanos, Lisboa, n. 7-8, p. 105-124, 2005

FONTE, Felipe de Melo. Políticas públicas e direitos fundamentais. São Paulo: Saraiva, 2013.

FREIRE, Paulo; GUIMARÃES, Sérgio. A África ensinando a gente: Angola, GuinéBissau, São Tomé e Príncipe. São Paulo: Paz e Terra, 2003.

FREITAS, João da Costa. Política de ensino em Angola. Lisboa: Universidade Técnica de Lisboa, 1964.

FULLAN, Michael. The new meaning of educational change. 4. ed. New York: Teachers College Press, 2007. 
HABTE, Akilu; MAGAW, Teshome. Educação e mudança social. In: MAZRUI, Ali; WONDJI, C. (Eds.). História geral da África desde 1935. 2. ed. São Paulo: Cortez, 2011. v.8. p. 817-845.

HALPIN, David; TROYUNA, Barry. The politics of education policy borrowing. Comparative Education. v. 31, n. 3, p. 303-310. 1995.

HENDERSON, Lawrence W. The church in Angola: a river of many currents. Cleveland, Ohio: the Pilgrim Press, 1992.

HEUGH, Kathleen. Da língua materna ao uso de uma língua materna no processo de ensino e aprendizagem: as limitações do modelo de "transição" no sistema escolar em Africa. In: CHIMBUTANE, Feliciano; STOUD, Christoplan. Educação bilíngue em Moçambique: refletindo criticamente sobre políticas e praticas. Maputo: Texto Editores, 2011.

HEYNEMAN, Stephen P. The history and problems in the making of education policy at the World Bank, 1960-2000. In: BAKER, David P.; WISEMAN, Alexander (Eds.). International perspectives on education and society: global trends in education policy. New York: Elsevier, 2005. v. 6. p. 1-21.

HILL, Michael. The public policy process. 4. ed. Essex: Pearson, 2005.

HODGES, Tom. Angola do afro estalinismo ao capitalismo selvagem. Parede: Princípio Editora, 2002.

JACOBSEN, Rebecca. The voice of people in education policy. In: SYKES, Gary et alli. (Eds.). Handbook of education policy research. New York: Routledge, 2009.

JACOMINI, Márcia Aparecida. Educar sem reprovar: desafios de uma escola para todos. Educação e Pesquisa, São Paulo, v. 35, n. 3, p.557-572, set./dez. 2009.

JACOMINI, Márcia Aparecida. Por que a maioria dos pais e alunos defende a reprovação? Cadernos de Pesquisa, v. 4, n. 141, p. 895-919, set./dez. 2011.

JANSEN, Jonathan D. Explaining non-change in education reform after apartheid: political symbolism and the problem of policy implementation. In: SAYED, Yusuf; JANSEN, Jonathan (Eds.). Implementing education policies: the South African experience. Cape Town: University of Cape Town Press, 2001. p. 271-289.

KI-ZERBO, Joseph. Educate or Perish. Paris: Unesco, 1990.

KLEES, Steven J. World Bank and education:ideological premises and ideological conclusions. In: KLEES, Steven J.; SAMOFF, Joel; STROMQUIST, Nelly P. (Eds.). The World Bank and education critiques and alternatives. Boston: Sense Publishers, 2012.

LEVIN, Benjamin. Reforming education: from origins to outcomes. New York: Routledge Falmer, 2001. 
LIBERATI, Wilson Donizeti. Políticas públicas no Estado constitucional. São Paulo: Saraiva, 2013.

MAINARDES, Jefferson. Análise de políticas educacionais: breves considerações teórico-metodológicas. Contrapontos, Itejai, v. 9, n. 1, p. 4-16 jan./abr. 2009.

MANGANYI, N. C. Public policy and the transformation of education in South Africa. In: SAYED, Yusuf; JANSEN, Jonathan (Eds.). Implementing education policies: the South African experience. Cape Town: University of Cape Town Press, 2001. p. 25-37.

MARX, Karl; ENGELS, Friedrich. Textos sobre a educação e ensino. 5. ed. São Paulo: Centauro, 2006.

MATSUURA, Koichiro. A Unesco e os desafios do novo século. Brasília, DF: Unesco, 2002.

McDONNEL, Lorrain M. A political science perspective on education policy analysis. In: SYKES, Gary et alli. (Eds.). Handbook of education policy research. New York: Routledge, 2009.

MEAD, Julie F. The role of law in education policy formation, implementation, and research. In: SYKES, Gary et alli. (Eds.). Handbook of education policy research. New York: Routledge, 2009.

MONDLANE, Eduardo. Lutar por Moçambique. Lisboa: Livraria Sá da Costa, 1977.

MONDOLFO, Rodolfo. Problemas de cultura e de educação. São Paulo: Mestre Jou, 1967.

MORRIS, Michael W. et alli. Views from inside and outside: integrating emic and etic insights about culture and justice judgement. Academic of Management Review,n. 4, p. 781-796, 1999.

MOUTINHO, Mário C. O indígena no pensamento colonial português:1895-1961. Lisboa: Edições Universitárias Lusófonas, 2000.

MUNDY, Karen; GALI, Mona. International and transnacional policy actors in education. A review of research. In: SYKES, Gary et alli. (Eds.). Handbook of education policy research. New York: Routledge, 2009.

MUNDY, Karen. Education for all: paradoxes and prospects of a global promisse. In: BAKER, David P.; WISEMAN, Alexander W. (Eds.). Education for all: global promisses, national changes: international perspectives on education and society. Oxford: Elsevier, 2007. v. 8. p. 1-30.

NAPIER, Diane Brook. Implementing educational transformation policies: investigating issues of ideal versus real in developing countries. In: BAKER, David P.; WISEMAN, 
Alexander (Eds.). International perspectives on education and society: global trends in education policy. New York: Elsevier, 2005. v. 6. p. 59-98.

NES, Kari. Why does education for all have to be inclusive education? In: ALLAN, Julie (Eds.). Inclusion, participation and democracy: what is the purpose? Dordrecht: Kluwer Academic Publishers, 2003. p. 67-80.

NERY JUNIOR, Nelson; NERY, Rosa M. de Andrade. Constituição Federal comentada e legislação constitucional. 2. ed. São Paulo: Revista dos Tribunais, 2009.

NEWMAN, Michael. Socialism a very short introduction. Oxford: Oxford University Press, 2005.

NGABA, André Vela. Políticas educativas em Angola (1975-2005): entre o global e o local: o sistema educativo mundial. Mbanza-Kongo: Sedieca, 2012.

NORDTVEIT, Bjorn H. World Bank poetry. How education strategy 2020 imagines the world. In: KLEES, Steven J.; SAMOFF, Joel; STROMQUIST, Nelly P. (Eds.). The World Bank and education critiques and alternatives. Boston: Sense Publishers, 2012.

NYERERE, Julius. Education for self-reliance. 1967. Disponível em: $<$ http://www.juliusnyerere.info/index.php/resources/speeches/education_for_self_reliance />. Acesso em: 16 ago. 2013.

OLIVEIRA, Romualdo P. Educação e Sociedade na Assembleia Constituinte de 1946. 1990. Dissertação (Mestrado em Educação) - Faculdade de Educação, Universidade de São Paulo. São Paulo, 1990.

OLIVEIRA, Romualdo P.; ADRIÃO, Theresa (Orgs.). Gestão, financiamento e direito à educação. São Paulo; Xamã, 2007.

ONU. Carta das Nações Unidas e Estatuto da Corte Internacional da Justiça. Rio de Janeiro: UNIC, 2001.

ONU. Committee on Economic, Social and Cultural Rights. The right to education (Doc. HRI/GEN/1/Rev.6 at 70), 1999. Disponível em: <http://www.umn.edu/humanrts/gencomm/escgencom13.htm>. Acesso em: 24 mar. 2014.

ONU. Declaração Universal dos Direitos Humanos. Rio de Janeiro: UNIC, 2000.

ONU. Pacto internacional dos direitos econômicos, sociais e culturais. 1966. Disponível em:

<http://www.oas.org/dil/port/1966\%20Pacto\%20Internacional\%20sobre\%20os\%20Direit os\%20Económicos,\%20Sociais\%20e\%20Culturais.pdf >. Acesso em: 24 mar. 2014. 
PAGE, Edward C. The origins of policy. In: MORAN, Michael; REIN, Martin; GOODIN, Robert E. (Eds.). The Oxford handbook of public policy. Oxford: Oxford University Press, 2006. p. 207-227.

PARO, Vítor Henrique. Educação como exercício de poder: crítica ao senso comum em educação. 2. ed. São Paulo: Cortez, 2010.

PARO, Vitor Henrique. Gestão escolar, democracia e qualidade do ensino. São Paulo, Ática, 2007.

PARO, Vitor Henrique. O princípio da gestão escolar democrática no contexto da LDB. In: OLIVEIRA, Romualdo Portela de; ADRIÃO, Theresa. Gestão, financiamento e direito à educação: análise da LDB e da Constituição Federal. São Paulo: Xamã, 2001. p. 79-88.

PNUD. Assistência técnica ao Ministério do Plano. Área infra-estruturas educativas. Projecto $n^{o}$ ANG/89/018. Luanda, 1992. Relatório da Missão (9 a 30 de junho de 1992).

PORTUGAL. Colónia de Angola. Direcção dos Serviços de Economia. Repartição de Estatística Geral. Censo Geral da População 1940: população presente, civilizada, segundo a nacionalidade e naturalidade. Luanda: Imprensa Nacional, 1943a. v. 5.

PORTUGAL. Colónia de Angola. Direcção dos Serviços de Economia. Repartição de Estatística Geral. Censo Geral da População 1940: população não civilizada, segundo a religião e grupos étnicos. Luanda: Imprensa Nacional, 1943b. v. 9.

PORTUGAL. Constituição política da República Portuguesa. Diário do Governo, 22 fev. 1933.

PORTUGAL. Decreto n. 18.570. Aprova o Acto Colonial, em substituição do titulo V da Constituição Política da República Portuguesa. Diário do Governo, I série, n. 156, 8 jul. 1930.

PORTUGAL. Decreto-Lei n. 39.666. Promulga o Estatuto dos Indígenas Portugueses das Províncias da Guiné, Angola e Moçambique. Boletim oficial da Colônia de Angola, 2 jun. 1954.

PORTUGAL. Decreto-Lei $n^{o}$. 30.207 de 05 de abril de 1941. Aprova o Estatuto Missionário.

PORTUGAL. Direcção Geral do Ensino. Portaria n. ${ }^{\circ}$ 20.380. Boletim oficial da Colônia de Angola, 7 mar. 1964.

PORTUGAL. Ministério da Educação Nacional. Decreto Lei n. 42.994. Actualiza os programas do ensino primário a adoptar a partir do próximo ano lectivo. Declara obrigatória a frequência da $4 .^{\mathrm{a}}$ Classe para todos os menores com a idade escolar prevista no artigo 1. ${ }^{\circ}$ do Decreto-Lei no 38.968. Boletim Oficial de Angola, 24 ago. 1960. 
PORTUGAL. Província da Angola. Direção dos Serviços de Estatística. Anuário estatístico 1967. Luanda: Imprensa Nacional, 1968.

PORTUGAL. Província de Angola. Direção dos Serviços de Estatística. Anuário estatístico 1968. Luanda: Imprensa Nacional, 1969a.

PORTUGAL. Província de Angola. Direcção dos Serviços de Economia e Estatística Geral. $3^{\circ}$ Recenseamento Geral da População 1960: população segundo as nacionalidades e naturalidades. Luanda: Imprensa Nacional, 1969b.v. 2.

PORTUGAL. Província de Angola. Direcção dos Serviços de Economia e Estatística Geral. $3^{\circ}$ Recenseamento Geral da População 1960: população residente segundo as condições perante o trabalho. Luanda: Imprensa Nacional, 1969c. v. 4.

PORTUGAL. Província de Angola. Repartição Técnica de Estatística Geral. II Recenseamento Geral da População 1950: população civilizada, presente, segundo o grau de instrução e o estado civil. Luanda: Imprensa Nacional, 1955a. v. 3.

PORTUGAL. Província de Angola. Repartição Técnica de Estatística Geral. II Recenseamento Geral da População 1950: população não civilizada, segundo as idades, a religião, os grupos étnicos, as mulheres que geram filhos e a instrução, por Conselhos ou Circunscrições. Luanda, Imprensa Nacional, 1955b. v. 4.

PORTUGAL. Província de Angola. Repartição Técnica de Estatística Geral. II Recenseamento Geral da População 1950: população segundo o tipo somático e o sexo, famílias e conivências. Prédios e fogos. Luanda, Imprensa Nacional, 1955c. v.1.

PORTUGAL. Regulamento do ensino rudimentar e do magistério rudimentar: 6 de fevereiro de 1950. (Boletim oficial da Colônia de Angola).

PORTUGAL. Secretariado da Propaganda Nacional. Acto colonial de 1930: a obra colonial do Estado Novo. Agencia geral das Colonias, 1942.

PRATA, Ndola. La scolarisation en Angola: résultats de l'enquête MICS-1996. Paris: Centre Français sur la population et le developpement, 2000.

PROBYN, Margie. Language and the struggle to learn: the intersection of classroom realities, language policy, and neocolonial and globalization discourses in South African schools. In: LIN, Angel M. Y.; MARTIN, Peter W. (Eds.). Decolonisation, globalisation, language-in-education, policy and pratice. New York: Multilingual Matters, 2005. p.153172.

RABIN, Yoran. The many faces of the right to education. In: BARAK-EREZ, Daphne; GROSS, Aeyal M. Exploring social rights: between theory and pratice. Portland: Hart Publishing, 2007. p 265-288.

ROCKWELL, Elsie. Hacer escuela, hacer Estado: la education pos revolucionaria vista desde Tlaxcala: Michoacan; Colegio de Michoacan, CIESAS y Cinvestav. 2007. 
RODNEY, Walter. How Europe underdeveloped Africa. Washinghton, DC: Howard University Press, 1982.

ROSA, Milton de Daniel Clark Orey. The field of research in ethnomodeling: emic, ethical and dialectical approaches. Educação e Pesquisa, São Paulo, v. 38, n. 4, p.865879, out./dez. 2012.

SANTOS, Aurora Almada. Os "ventos de mudança" e a descolonização: a ONU e as resoluções da Assembleia Geral de Dezembro de 1960. Relações Internacionais, n. 30, p. 61-69, jun. 2011.

SAYED, Yusuf; JANSEN, Jonathan (Eds.). Implementing education policies: the South African experience. Cape Town: University of Cape Town Press, 2001.

SEN, Amartya. The ideia of justice. Cambridge, MA: Belknap Press, 2009.

SHIZHA, Edward. Reclaiming our memories: the education dilema in post colonial african school curriculum. In: ABDI, ALI A.; CLEGHORN, Ailie. (Eds.). Issues in African Education. sociological perspectives. New York: Palgrave Macmillan, 2005.

SILVA, A. E. Duarte. O litígio entre Portugal e a ONU (1960-1974). Análise Social, v. 130, n. 1, p. 5-55, 1995.

SILVA, José Pinheiro. A educação e o futuro de Angola (1970). Lisboa: Edição NEOS, 2009.

SPRING, Joel. Desculturalization and the struggle for equality: a brief history of the education of dominated cultures in the United States. 4. ed. Boston: McGraw Hill, 2004.

STEINER-KHANSI, Gita. For all by all? the World Bank's global framework for education. In: KLEES, Steven J. ; SAMOFF, Joel; STROMQUIST, Nelly P. (Eds.) The World Bank and education critiques and alternatives. Boston: Sense Publishers, 2012.

STROMQUIST, Nelly P. State and civil society response to education for all: Linking global dreams to national realities in Peru. In: BAKER, David P.; WISEMAN, Alexander W. (Eds.). Education for all: global promisses, national changes: international perspectives on education and society. Oxford: Elsevier, 2007. v. 8. p. 257-278.

TARAS, Ray. Ideology in a socialist state: Poland 1956-1983. Cambridge: Cambridge University Press, 1984.

TEIXEIRA, Anísio. Educação e nacionalismo. Revista Brasileira de Estudos Pedagógicos, Rio de Janeiro, v. 34, n. 80, p. 205-208, out./dez. 1960.

TEIXEIRA, Anísio. Educação não é privilegio. Revista Brasileira de Estudos Pedagógicos. Brasília-DF, v. 70, n. 166, p. 435-462, 1989. 
TOMASEVSKI, Katarina. Human rights obligations: making education available, acessible, acceptable and adaptable. Gotehenburg: Novum Grafiska AB, 2001. (Right to Education Primers, n.3).

UNESCO; UNICEF. A human right-based approach to education for all. New York, 2007.

VALENTE, Ivan; ARRELARO, Lizete. Educação e políticas públicas. São Paulo: Xamã, 2002.

VALLY, S.; Carol Anne Spreen. Human rights in the World Bank 2020 education strategy. In: KLEES, Steven J.; SAMOFF, Joel; STROMQUIST, Nelly P. (Eds.) The World Bank and education critiques and alternatives. Boston: Sense Publishers, 2012.

VAN ZANTEN, Agnes (Coord.). Dicionário de educação. Petrópolis, RJ: Vozes, 2011.

VIEIRA, Laurindo. Angola: a dimensão ideológica da educação: 1975-1992. Luanda: Nzila, 2004.

VILAKAZI, Herbert W. The problem of education in África. In: HIGGS P. et al. African voices in Education. Ndabeni, Western Cape: The Rustic Press, 2000.

WEIMER, David L. Making education research more policy-analytic. In: SYKES, Gary et alli. (Eds.). Handbook of education policy research. New York: Routledge, 2009.

WISEMAN, Alexander W.; BAKER, David P. The worldwide explosion of internationalized education policy. (pages 1-21) In: BAKER, David P.; WISEMAN, Alexander (Eds.). International perspectives on education and society: global trends in education policy. New York: Elsevier, 2005. v. 6.

WOLHUTER, C. C. Education for all in sub-Saharan Africa: prospects and challenges. In: BAKER, David P.; WISEMAN, Alexander W. (Eds). Education for all: global promisses, national changes: international perspectives on education and society. Oxford: Elsevier, 2007. v. 8. p. 337-362.

WORLD BANK. Implementation completion report. 2000 Disponível em: <http://wwwwds.worldbank.org/external/default/WDSContentServer/WDSP/IB/2000/04/19/00009494 6_00040502431719/Rendered/PDF/multi_page.pdf>. Acesso em: 24 mar. 2014.

WORLD BANK. Memorandum and recommendation of the president of the international development association to the executive director on a proposed credit of SDR 11.9 million to the People's Republic of Angola for the First Education Project. 1992. Disponível em: <http://wwwwds.worldbank.org/external/default/WDSContentServer/WDSP/IB/2000/04/19/00009494 6_00040502431719/Rendered/PDF/multi_page.pdf >. Acesso em: 24 mar. 2014.

WORLD BANK. Staff appraisal report: people's Republic of Angola: First Education $\begin{array}{lllll}\text { Projec. } & 1992 . & \text { Disponível }\end{array}$ 
wds.worldbank.org/external/default/WDSContentServer/WDSP/IB/1992/05/01/00000926 5_3961002074221/Rendered/PDF/multi_page.pdf >. Acesso em: 24 mar. 2014.

ZAU, Filipe. Educação em Angola: novos trilhos para o desenvolvimento. Luanda: Movilivros, 2009. 


\section{ANEXO I - Sobre o Conselho da Revolução}

Na Lei Constitucional de 1975 (Lei 1/75)

-Enquanto não estiverem preenchidas as condições para a instituição da Assembleia do Povo, o órgão supremo do Poder do Estado é o Conselho da Revolução. (artigo 35)

O Conselho da Revolução é constituído:

a) Pelos membros do comitê central do MPLA-Partido do Trabalho;

b) Pelo Ministro da Defesa, Chefe do Estado-Maior-Geral das FAPLA [Forças Armadas], Comissário Político Nacional e Por responsáveis destes organismos designados para o efeito pelo Presidente da República;

c) Pelos membros do governo designados para o efeito pelo Bureau Político do Comité Central do MPLA - Partido do Trabalho, no máximo de três não membros do comitê central;

d) Pelos Comissários províncias [atualmente governadores] designados para o efeito pelo Presidente da República;

e) Pelos comandantes das regiões militares;

f) Pelos representantes das direções nacionais da JMPLA, OMA e da ODP [defesa civil] designados pelo Bureau Político do MPLA-Partido do Trabalho. (artigo 36)

O Conselho da Revolução tem as seguintes atribuições:

a) Deliberar e decidir com base nas resoluções do Comité Central do MPLA Partido do Trabalho, sobre as questões fundamentais da política interna e externas do Estado;

b) Exercer a função legislativa, conjuntamente com o governo;

c) Aprovar o Plano Nacional e o orçamento geral do estado, elaborados pelo Governo, bem como apreciar os relatórios sobre a sua execução;

d) Autorizar o Presidente da República a declarar a guerra e a fazer a paz;

e) Conceder amnistia;

f) Aprovar, os Tratados de amizade e os que versem sobre a participação da República Popular de Angola em organizações internacionais. (Artigo 38)

Compete exclusivamente ao Conselho da Revolução fazer leis sobre as seguintes matérias:

a) Direitos, deveres e garantias fundamentais dos cidadãos;

b) Nacionalidade, estado e capacidade das pessoas;

c) Bases gerais da organização da defesa e da segurança nacional;

d) Bases gerais da estrutura e do poder do Estado;

e) Bases gerais sobre o trabalho e segurança social, educação e saúde;

f) Bases gerais sobre o regime da propriedade;

g) Criação de tribunais;

h) Criação de bancos e outras instituições de credito e emissão de moeda. (artigo 39) 
ANEXO II - Organograma do sistema de educação: idades mínimas de ingresso

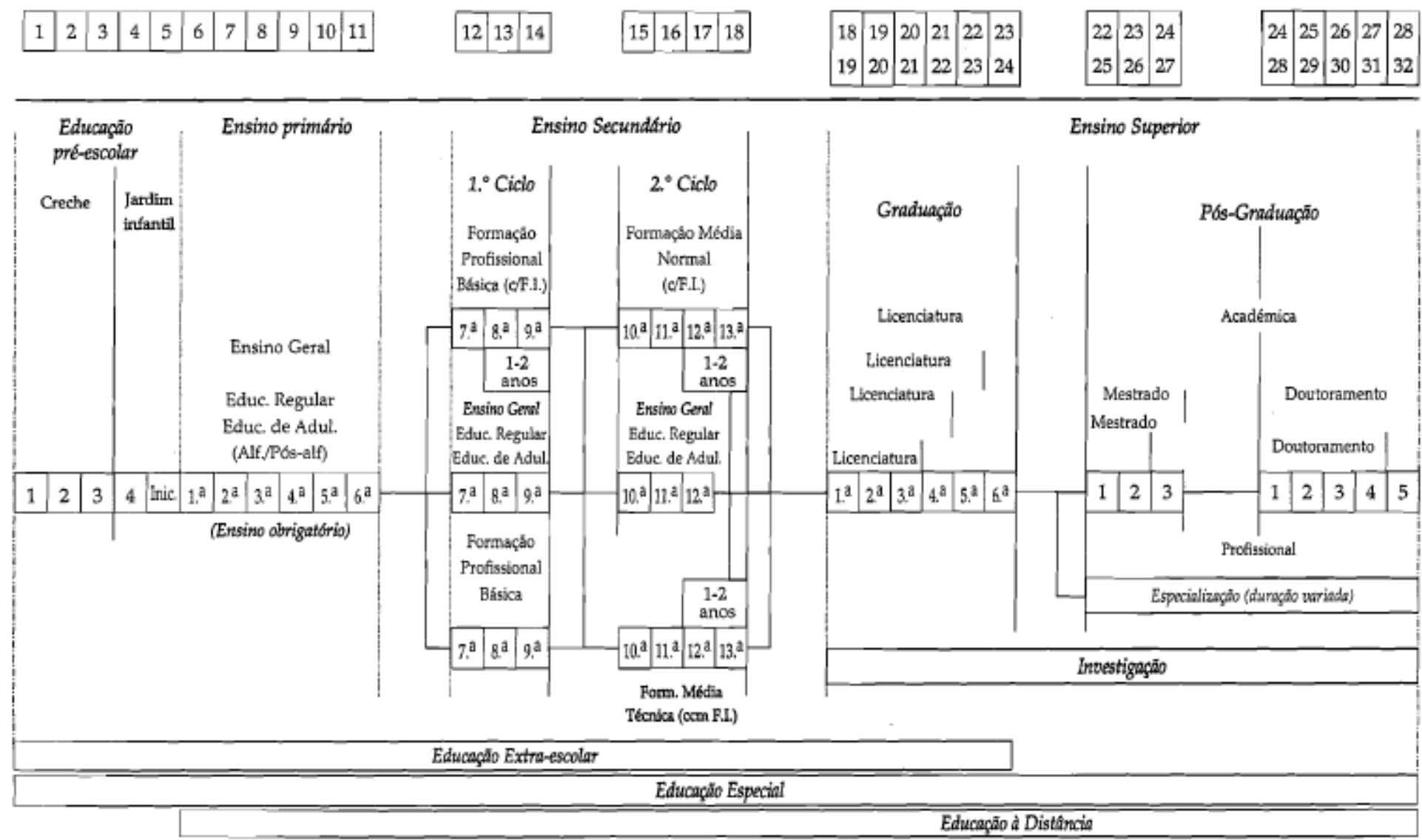

O Primeiro Ministro, Fernando da Piedade Dias dos Santos.

O Presidente da República, José Eduardo dos Santos. 
ANEXO III - Comparação entre o sistema de educação em vigor e o sistema de educação a implementar: idades mínimas de ingresso

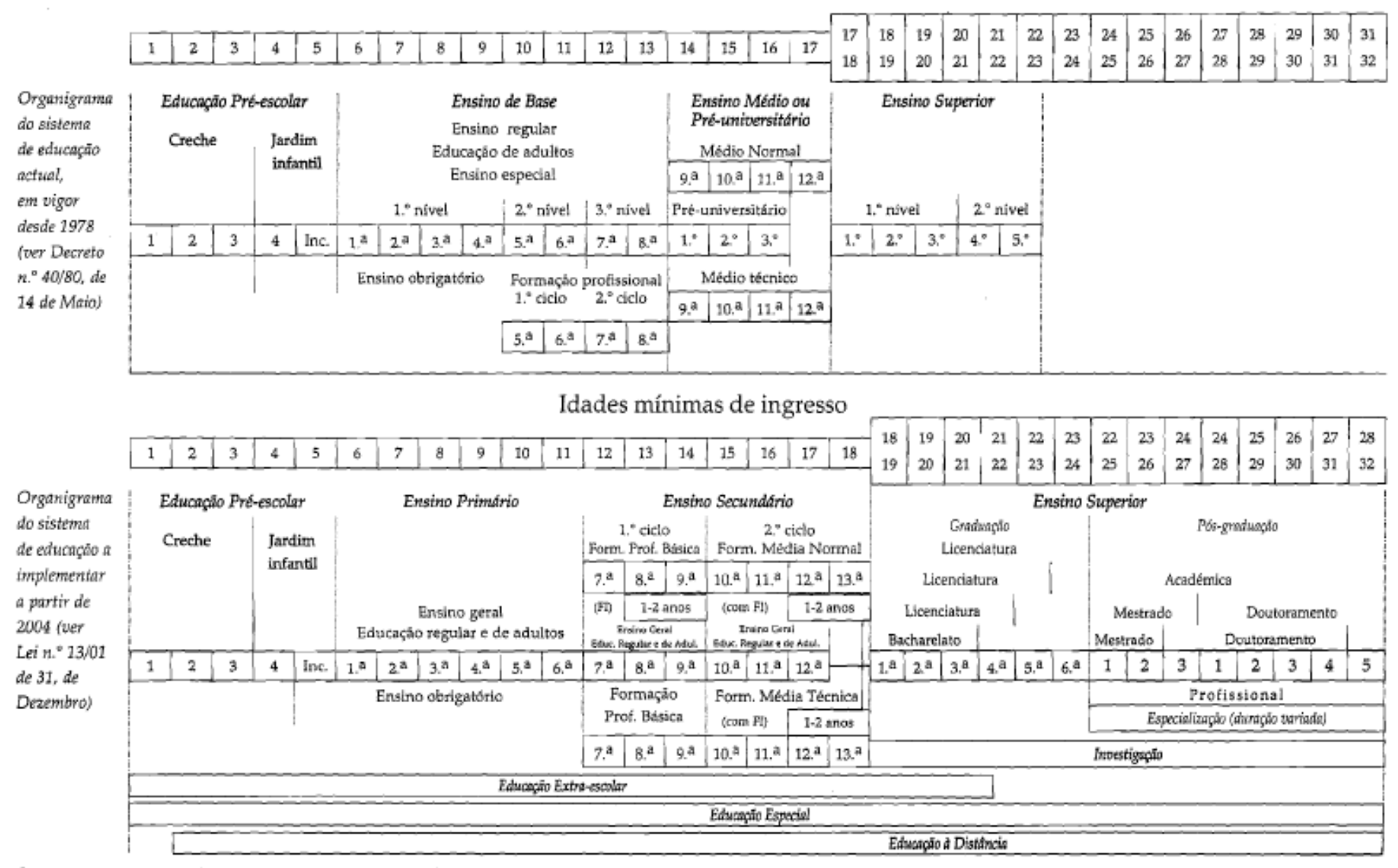

O Primeiro Ministro, Fernando da Piedade Dias dos Santos.

O Presidente da República, Josế Eduardo dos SANTos. 


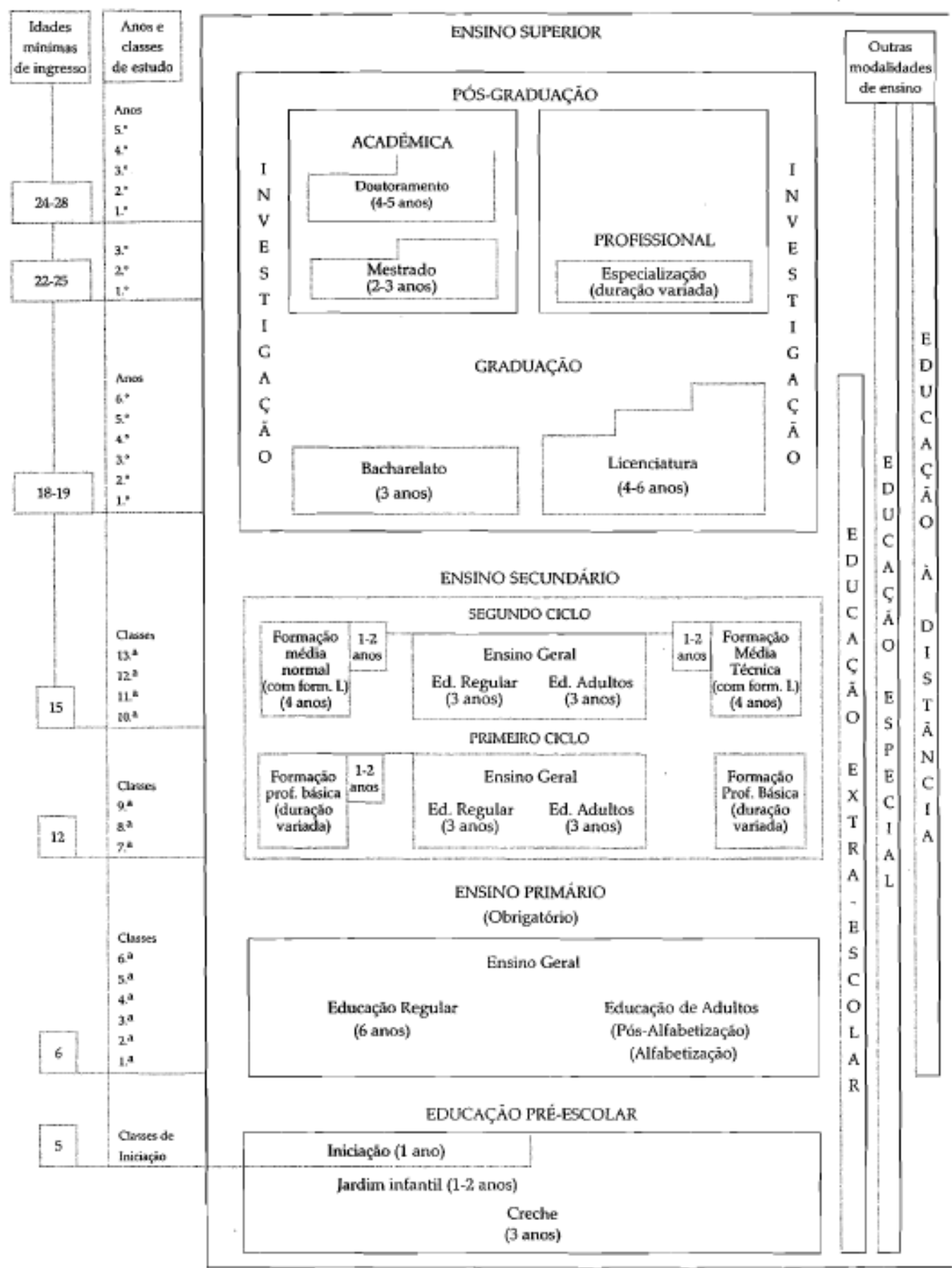

O Primeiro Ministro, Fernando da Piedade Dias dos Santos.

O Presidente da República, JosÉ Eduardo dos SANTOS.

ANEXO IV - Organograma 
ANEXO V - Mapa Etnolinguístico de Angola

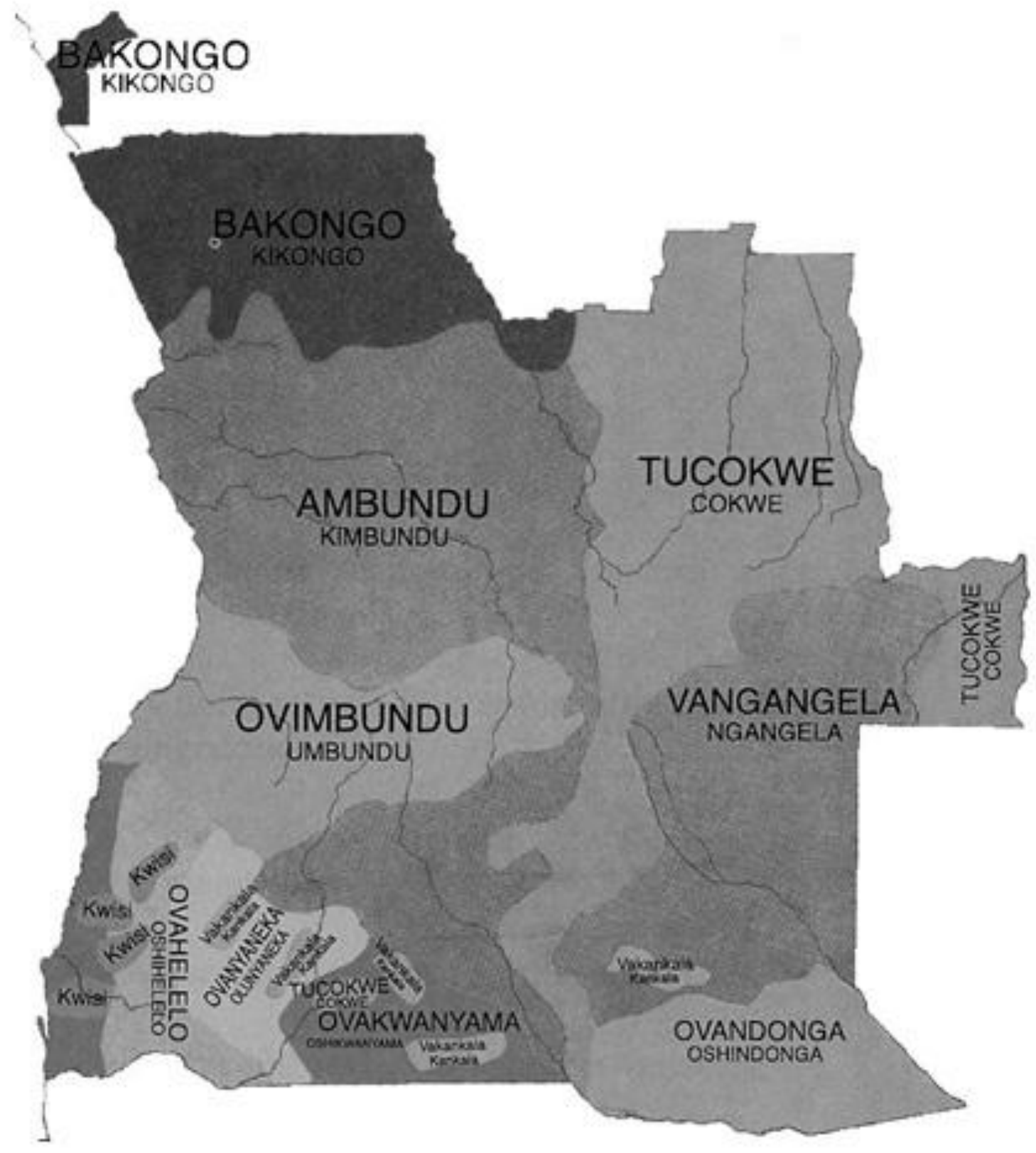


ANEXO V - Angola e os países limítrofes

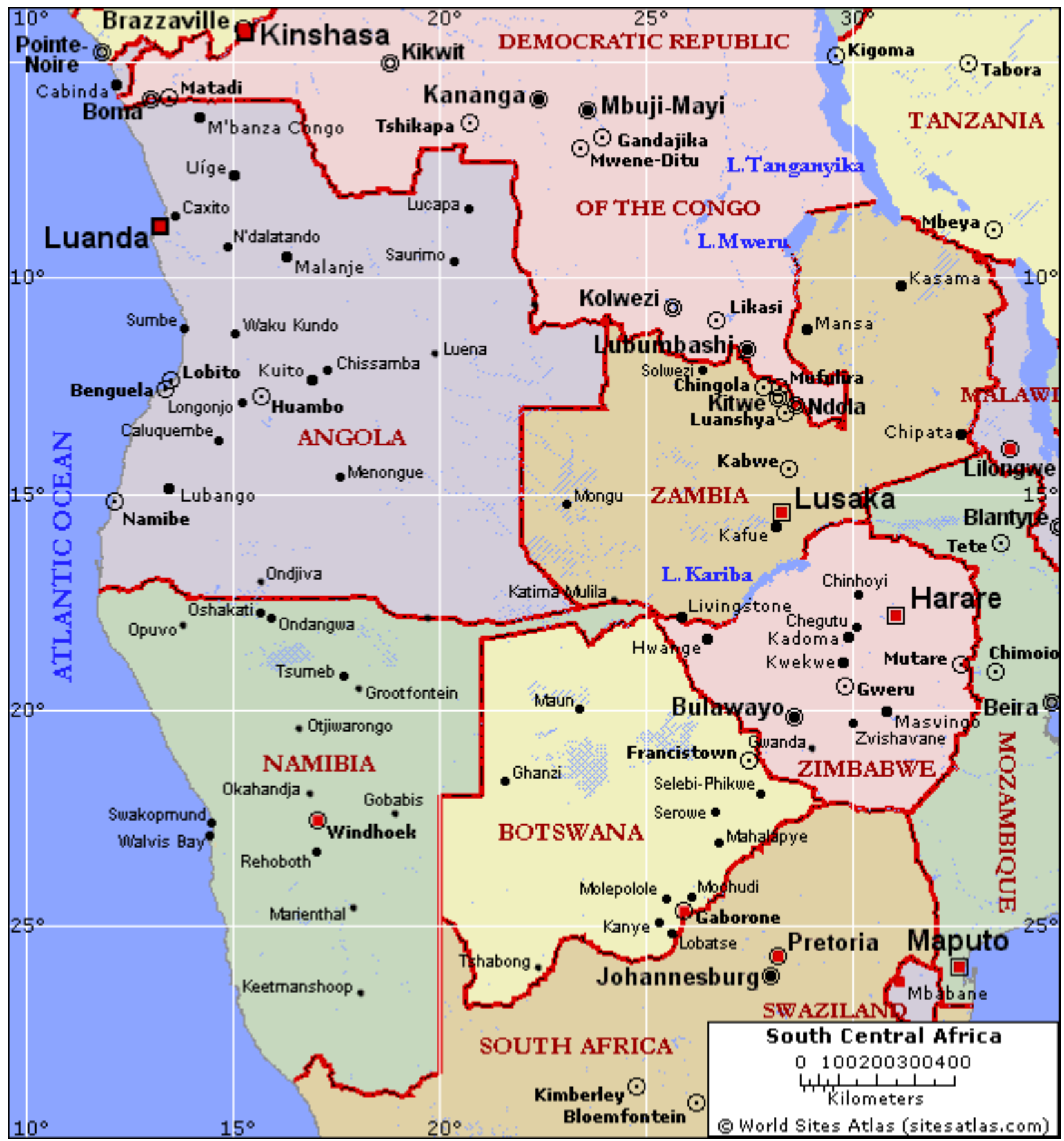

